Uniwersytet Przyrodniczy w Lublinie

\title{
Wybrane zagadnienia z zakresu bromatologii
}

Środowisko - Roślina - Zwierzę - Produkt 
Wybrane zagadnienia

z zakresu bromatologii 
Środowisko - Roślina - Zwierzę - Produkt 


\title{
Wybrane zagadnienia z zakresu bromatologii
}

\author{
pod redakcją \\ Marka Babicza \\ Kingi Kropiwiec-Domańskiej
}

Lublin 2021 


\title{
Recenzent
}

prof. dr hab. inż. Małgorzata Krzywonos

\author{
Opracowanie redakcyjne \\ Agnieszka Litwińczuk \\ Skład i łamanie \\ Małgorzata Grzesiak \\ Projekt okładki \\ Jacek Pałyszka

\section{(1) $(1) \Theta \Theta$}

Ten utwór jest dostępny na licencji Creative Commons Uznanie autorstwa Użycie niekomercyjne - Bez utworów zależnych 4.0 Międzynarodowe.

\section{ISBN 978-83-7259-341-2 on-line}

DOI: 10.24326/mon.2021.8

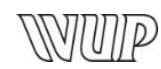

Wydawnictwo Uniwersytetu Przyrodniczego w Lublinie

ul. Akademicka 15, 20-950 Lublin

https://up.lublin.pl/nauka/wydawnictwo/

9,5 ark. wyd. 


\section{Spis treści}

Piotr Domaradzki, Anna Teter, Marek Kowalczyk, Mariusz Florek,

Monika Kędzierska-Matysek, Justyna Zdyb-Domaradzka, Małgorzata Dmoch,

Katarzyna Zdrzałek, Aneta Krawiec

Rola i znaczenie programów edukacji żywieniowej kierowanych do dzieci

i młodzieży szkolnej

The role and importance of nutritional education programs targeted at schoolchildren

and adolescents

\section{Gabriela Gutowska, Kaja Kiersnowska}

Związki bioaktywne żywności stosowane w dietoterapii depresji

Bioactive food compounds used in the diet therapy in depression disease

Katarzyna Iłowiecka, Paweł Glibowski, Justyna Bochnak-Niedźwiecka

Przyczyny i wielowymiarowe konsekwencje otyłości

Causes and multidimensional consequences of obesity

Karolina Jachimowicz, Kinga Burczaniuk, Marlena Sagan, Maciej Bąkowski

Stosowanie żywności jako formy nagradzania i/lub karania dzieci w wieku przedszkolnym

Using food as a form of reward and/or punishment children of pre-school age

Anna Jańczuk

Przyczyny zaniechania karmienia piersią

Reasons for breastfeeding termination

Paulina Jedut, Iwona Niedźwiedź, Pawel Glibowski

Najczęstsze niedobory żywieniowe w diecie wegetarian i sposoby im zapobiegania

The most common nutritional deficiencies in the diet of vegetarians and ways to prevent them

Natalia Kaniewska, Justyna Kupiec

Znaczenie bioaktywnych związków żywności w rozwoju i profilaktyce chorób neurodegeneracyjnych

The importance of bioactive nutritional compounds in the development and prevention

of neurodegenerative diseases

Malgorzata Kawalec, Aleksandra Garbacz, Marta Dec

Nietolerancja laktozy - przyczyny i diagnostyka 58

Lactose intolerance - causes and diagnosis

\section{Kaja Kiersnowska, Gabriela Gutowska}

Substancje psychoaktywne jako nowoczesna metoda leczenia zaburzeń psychicznych 66

Psychoactive substances as a modern method of treating mental disorders 


\section{Karolina Lanoszka, Joanna Kapusta-Duch}

Nawyki żywieniowe pacjentów bariatrycznych oraz rola żywienia w chirurgicznym leczeniu otyłości

Eating habits in bariatric surgery patients and the role of nutrition in surgical treatment of obesity

\section{Joanna Mrożek, Aleksandra Pajor, Aneta Koronowicz}

Wpływ sałaty biofortyfikowanej w jodosalicylany na żywotność komórek nowotworowych - badania in vitro w modelu komórek gruczołu piersiowego MCF-7

The effect of biofortified lettuce in iodosalicylates on the viability of neoplastic cells

- in vitro studies in the MCF-7 breast gland cell model

Rafal Oleszczuk, Agnieszka M. Grzebalska, Michał Smyka, Jakub Mendocha

Pozytywny i negatywny wpływ witaminy D na organizm człowieka

Positive and negative influence of vitamin $\mathrm{D}$ on the human body

Rafal Oleszczuk, Agnieszka M. Grzebalska, Michal Smyka, Jakub Mendocha

Witamina D w przewlekłej chorobie nerek

Vitamin D in chronic kidney disease

\section{Ewa Potent, Justyna Libera}

Preferencje żywieniowe dzieci i decyzje zakupowe rodziców dotyczące produktów mlecznych

Children's nutritional preferences and parents' purchasing decisions in relation

to the dairy products

\section{Aleksandra Such, Anna Pelc, Aneta Koronowicz}

Ocena stanu wiedzy rodziców na temat wpływu nieprawidłowych zachowań żywieniowych na rozwój otyłości prostej u dzieci - badania ankietowe

The evaluation of parents' state knowledge about the impact of incorrect dietary

behaviors on development of simple obesity in children - surveys 


\author{
Piotr Domaradzki ${ }^{1}$, Anna Teter ${ }^{1}$, Marek Kowalczyk ${ }^{1}$, Mariusz Florek ${ }^{1}$, \\ Monika Kędzierska-Matysek ${ }^{1}$, Justyna Zdyb-Domaradzka ${ }^{2}$, Małgorzata Dmoch ${ }^{1}$, \\ Katarzyna Zdrzałek ${ }^{1}$, Aneta Krawiec ${ }^{1}$
}

\title{
Rola i znaczenie programów edukacji żywieniowej kierowanych do dzieci i młodzieży szkolnej
}

The role and importance of nutritional education programs targeted at schoolchildren and adolescents

Żywienie to jeden z najważniejszych czynników środowiskowych, wpływających na rozwój fizyczny i stan zdrowia człowieka. Dzieci i młodzież szkolna należą do grupy najbardziej narażonej na negatywne skutki nieodpowiedniego odżywiania oraz braku edukacji w tym zakresie. Błędy w sposobie odżywiania coraz częściej są przyczyną zaburzeń rozwoju psychomotorycznego dzieci, prowadzą do trudności w nauce oraz w życiu szkolnym młodego człowieka, a niejednokrotnie również w życiu dorosłym, predysponując do powstania wielu chorób dietozależnych. Utrwalone w dzieciństwie wadliwe nawyki żywieniowe często pogłębiane przez niekorzystną sytuację ekonomiczną rodzin, miejsce zamieszkania, stres i reklamę niezalecanej żywności, mogą prowadzić do nadwagi i otyłości prostej, cukrzycy czy chorób układu krążenia [Socha i in. 2002, Wądołowska 2011, Zalewska i Maciorkowska 2013].

Edukacja żywieniowa powinna być adresowana do różnych grup odbiorców, jednak przede wszystkim do dzieci i młodzieży, ponieważ zarówno styl życia, jak i związane z nim zachowania zdrowotno-żywieniowe kształtują się już od najmłodszych lat. Nie można w tych działaniach pominąć rodziców i nauczycieli jako ważnych opiniotwórców, a jednocześnie wzory do naśladowania przez najmłodszych [Zalewska i Maciorkowska 2013, Gutkowska i Adamowski 2019]. Status zawodowy i socjoekonomiczny rodziców oraz wykształcenie silnie oddziałują na zachowania żywieniowe dzieci - podstawową wiedzę o odżywianiu i nawyki żywieniowe nabywają przez obserwację zachowań domowników i z informacji uzyskanych od rodziców. Edukacja rodziców powinna być ukierunkowana na wzmocnienie świadomości i odpowiedzialności za kształtowanie zachowań żywieniowych i wzorców aktywności ruchowej dzieci. Warto podkreślić, że przez zakup określonej żywności rodzina bezpośrednio wpływa na zachowania żywieniowe dzieci i młodzieży [Matecka i Głowacka-Rębała 2007]. Oprócz rodziny istotny wpływ na postawy żywieniowe dzieci i młodzieży ma środowisko szkolne i przedszkolne. Olbrzymia różnorodność oddziaływań, w tym również w zakresie żywności i zasad ży-

${ }^{1}$ Uniwersytet Przyrodniczy w Lublinie, Wydział Nauk o Zwierzętach i Biogospodarki, anna.wolanciuk@up.lublin.pl

${ }^{2}$ Wojewódzka Stacja Sanitarno-Epidemiologiczna w Lublinie 
wienia, sprzyja kształtowaniu żywieniowych zachowań dzieci, m.in. przez posiłki oferowane na stołówkach, a także produkty udostępnione do sprzedaży w sklepikach [Zalewska i Maciorkowska 2013].

W edukacji żywieniowej można korzystać z całego wachlarza metod, form i środków aby promować dobre wzorce. Jednym z takich działań są realizowane w szkole programy edukacji żywieniowej mające za zadanie promocję zdrowego stylu życia, prawidłowo zbilansowanej diety bogatej w owoce i warzywa, a także aktywności fizycznej. Programy te są istotnym elementem profilaktyki chorób dietozależnych, w tym zwłaszcza nadwagi czy otyłości, które coraz częściej dotykają młode osoby. Według raportu Światowej Organizacji Zdrowia (WHO) nadwaga i otyłość są problemem globalnym, dotyczą bowiem aż $38 \mathrm{mln}$ dzieci poniżej 5 roku życia i ponad $340 \mathrm{mln}$ dzieci i młodzieży w wieku 5-19 lat [WHO 2020]. W Polsce sytuacja również nie napawa optymizmem, bowiem w 2016 r. nadwagę miało $31 \%$ chłopców i 20\% dziewcząt, a otyłość dotyczyła 13\% chłopców i 5\% dziewcząt [NFZ 2019]. Na utrzymanie prawidłowej masy ciała, oprócz żywienia, ma wpływ aktywność fizyczna - niestety, dane z różnych badań dotyczących populacji dzieci i młodzieży wskazują, że nie jest ona zadawalająca. Przykładowo z badań HBSC (Health Behaviour in School-aged Children) wynika, że odsetek młodzieży w wieku 10-19 lat spełniającej zalecenia WHO w zakresie umiarkowanej aktywności fizycznej, tj. min. 60 min aktywności ruchowej przez 7 dni w tygodniu, systematycznie spada i w 2018 r. wyniósł tylko 15,6\%. Co więcej odsetki młodzieży spełniającej rekomendacje w tym zakresie maleją wraz z wiekiem: od 23,2\% u 11-latków do 9,6\% u 17-latków [Fijałkowska 2018]. Z tego też względu popularność kampanii prozdrowotnych kierowanych głównie do dzieci i młodzieży ciągle rośnie, a ich twórcy wierzą, że poprzez edukację z zakresu żywienia rozpoczętą w jak najmłodszym wieku, można wpoić młodym osobom zasady zdrowej i zbilansowanej diety oraz znaczenia aktywności ruchowej w utrzymaniu dobrego stanu zdrowia.

Celem pracy była charakterystyka najważniejszych programów żywieniowych kierowanych do dzieci i młodzieży prowadzonych w latach 2004-2021 oraz przedstawienie ich roli i znaczenia w kształtowaniu prozdrowotnych nawyków żywieniowych i zachęcaniu do większej aktywności fizycznej.

\section{Charakterystyka wybranych ogólnopolskich programów z zakresu edukacji żywieniowej dzieci i młodzieży „Trzymaj formę!”}

Program zainicjowany został w 2006 r. przez Główny Inspektorat Sanitarny oraz Polską Federację Producentów Żywności Związek Pracodawców w ramach realizacji strategii WHO dotyczącej diety, aktywności fizycznej i zdrowia. Współorganizatorem Programu jest Fundacja Żywność, Aktywność Fizyczna i Zdrowie. Partnerem Programu jest Instytut Medycyny Wsi im. Witolda Chodźki w Lublinie. Celem głównym programu „Trzymaj Formę!” jest zwiększenie świadomości wpływu żywienia i aktywności fizycznej na zdrowie. Działania programowe kierowane są również do rodziców, jako że to oni wpływają ostatecznie na wzorce zachowań swoich dzieci. Program „Trzymaj Formę!” (ryc. 1) pomaga rozwijać zainteresowania młodzieży i kształtować ich prozdrowotne nawyki. Kierowany jest głównie do uczniów klas V-VIII szkół podstawowych. 


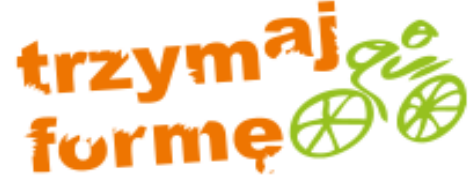 \\ Ryc. 1. Logo programu „Trzymaj formę!” \\ Źródło: http://www.trzymajforme.pl}

Program może być realizowany w formie zajęć edukacyjnych, ale preferowana $\mathrm{i}$ dominująca jest metoda projektu. Dzięki temu prezentowane treści-wykraczają poza podstawę programową i programy nauczania szkoły. Realizowane przez szkoły projekty powinny służyć rozwijaniu zainteresowań młodzieży, szczególnie dotyczących zasad racjonalnego odżywiania i potrzeby codziennej aktywności fizycznej. Oczekuje się, że będą łączyły aktywność uczniów, z ich oczekiwaniami oraz zaangażowaniem społeczności lokalnej, wykorzystując najnowszą dostępną wiedzę. Projekty kończą się przedstawieniem uzyskanych rezultatów. Powinny składać się z czterech etapów, tj. przygotowania, planowania, realizacji i prezentacji.

Po zakończeniu edycji programu, szkolni koordynatorzy zobowiązani są przygotować sprawozdanie opisujące jego przebieg i wykonanie oraz wysłać je do właściwych powiatowych stacji sanitarno-epidemiologicznych. Na tej podstawie organizatorzy podsumowują i oceniają jego realizację. W ramach programu „Trzymaj formę!” organizowane są również liczne konkursy, np. kulinarne, plastyczne, wiedzy o zdrowym stylu życia, zawody sportowe czy konkursy na projekty edukacyjne promujące zmianę zachowań w stylu życia. Zgodnie z założeniami programu żadne nazwy i znaki handlowe produktów żywnościowych lub firm produkujących żywność nie mogą być komunikowane i używane, ponadto przedmiotem projektów nie mogą być zagadnienia związane $\mathrm{z}$ handlem i promocją produktów żywnościowych [http://www.trzymajforme.pl].

„Trzymaj formę!” to największy w Unii Europejskiej (UE) program dotyczący racjonalnego odżywiania, edukacji konsumenckiej i aktywności fizycznej. W ramach zainicjowanego przez Komisję Europejską (KE) projektu Obesity Governance program „Trzymaj formę!” zyskał miano jednej z czterech najlepszych inicjatyw w zakresie edukacji dzieci i młodzieży.

\section{„Program dla szkól”}

„Program dla szkół” (ryc. 2) to unijny program koordynowany w Polsce przez Krajowy Ośrodek Wsparcia Rolnictwa, polegający na dostarczaniu dzieciom owoców i warzyw oraz mleka i produktów mlecznych. To kontynuacja dotychczasowych programów „Owoce i warzywa w szkole” i „Mleko w szkole”, które od roku szkolnego 2017/2018 zostały zastąpione jednym. Polska do programu „Mleko w szkole” (pierwotnie określanego mianem ,Szklanka mleka”) przystąpiła od razu po akcesji do Unii, czyli w 2004 r. W pierwszy roku działania do ww. programu zgłosiło się zaledwie 40 szkół. Z kolei program „Owoce w szkole” realizowany był od roku szkolnego 2009/2010. 
„Program dla szkół” jest częściowo finansowany z unijnych środków, bowiem KE co roku na ten cel przeznacza określony budżet, który dzielony jest na poszczególne kraje. Realizację działań wspiera także budżet krajowy. Polska jest jednym z największych beneficjentów programu - pod względem przyznanych środków plasuje się na 4. miejscu. W roku szkolnym 2019/2020 budżet na realizację programu w Polsce wyniósł łącznie $238 \mathrm{mln}$ zł, w tym $110 \mathrm{mln}$ zł pochodziło z budżetu UE, a $128 \mathrm{mln}$ zł z budżetu krajowego.

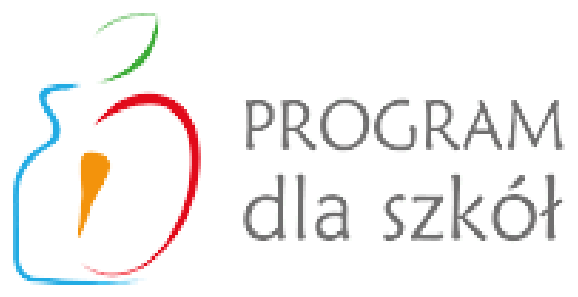

Ryc. 2. Logo programu „Program dla szkół” Źródło: https://www.programdlaszkol.org

Celem „Program dla szkół” jest propagowanie wśród dzieci zdrowych nawyków żywieniowych przez udostępnianie im produktów mlecznych oraz owocowo-warzywnych, tak aby od najmłodszych lat polubiły ich naturalny smak oraz poznały walory diety bogatej w te produkty. Oprócz promowania zdrowej diety program ma również pokazać dzieciom, skąd pochodzą owoce, warzywa oraz produkty mleczne, jak są uprawiane i produkowane. Organizatorzy za cel stawiają sobie nie tylko zwiększenie świadomości społecznej wśród dzieci, ale również wśród rodziców. W programie mogą uczestniczyć uczniowie z klas I-V szkół podstawowych, ogólnokształcących szkół muzycznych I stopnia oraz uczniowie klas I i II ogólnokształcących szkół baletowych. Dzieci otrzymują bezpłatnie w każdym z 12 tygodni semestru, co najmniej 3 porcje owoców i warzyw oraz nie mniej niż 3 porcje mleka i produktów mlecznych. Aby zwiększyć atrakcyjność i skuteczność programu rozszerzono katalog produktów, tak aby dzieci mogły poznać i polubić nowe smaki. Program ma kreować prozdrowotne postawy i zachowania dzieci, dlatego są im udostępniane produkty świeże i niskoprzetworzone o wysokich walorach zdrowotnych tj. owoce (jabłka, gruszki, truskawki, śliwki) i warzywa (marchew, rzodkiewki, papryka słodka, pomidorki, kalarepa), soki i przeciery owocowe, a także mleko spożywcze oraz naturalne produkty mleczne (jogurt, kefir, serek twarogowy). Jak podkreślają koordynatorzy programu, aby skutecznie kształtować nawyki żywieniowe dzieci, samo udostępnianie im produktów nie wystarczy. Dlatego też dzieci uczestniczą w specjalnych działaniach edukacyjnych prowadzonych przez szkoły zgodnie z wytycznymi Ministerstwa Edukacji i Nauki (MEN), które mają na celu naukę samodzielnego dokonywania właściwych wyborów żywieniowych, poszerzenie wiedzy o pochodzeniu owoców, warzyw i produktów mlecznych, zdrowej diecie czy przeciwdziałanie marnotrawieniu żywności [KOWR 2020, https://www.programdlaszkol.org]. 


\section{„ABC zdrowego żywienia"}

„ABC zdrowego żywienia” (ryc. 3) to ogólnopolski program edukacyjno-badawczy, którego celem jest zwięszenie świadomości żywieniowej oraz przedstawienie korzyści wynikających z większej aktywności fizycznej wśród dzieci i młodzieży w wieku szkolnym oraz ich rodziców. Program został opracowany i koordynowany przez Szkołę Główną Gospodarstwa Wiejskiego (SGGW) w Warszawie we współpracy z Carrefour Polska i ośmioma wiodącymi ośrodkami akademickimi w Polsce z Białej Podlaskiej, Białegostoku, Gdyni, Krakowa, Lublina, Olsztyna, Poznania i Wrocławia, a finansowany przez Fundację Carrefour. Program otrzymał też honorowy patronat Ministerstwa Edukacji Narodowej oraz Ministerstwa Zdrowia. W programie dominującą formą prowadzenia zajęć, umożliwiającą zdobycie wiedzy i umiejętności, są aktywizujące uczestników interaktywne warsztaty dostosowane do wieku i możliwości percepcji odbiorców, oparte m.in. na zmysłach.

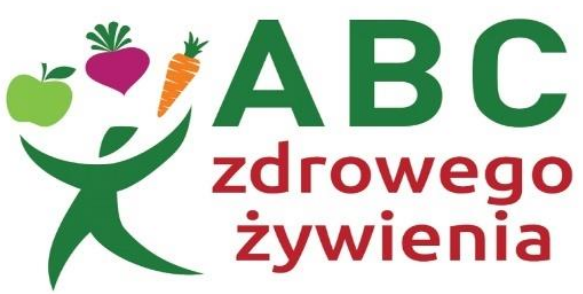

Ryc. 3. Logo programu „ABC zdrowego żywienia” Źródło: https://www.serwiskorporacyjny.carrefour.pl

Dotychczas odbyły się trzy edycje programu, zorganizowane w latach 2014-2018. Pierwsza edycja (2014-2015) zakładała edukację żywieniową nie tylko dzieci (7-14 lat), ale i seniorów (powyżej 65 roku życia). Druga edycja (2016) była skierowana do dzieci w wieku 11-13 lat ze szkół podstawowych. Trzecia edycja (2017-2018) była skierowana do uczniów klas drugich i trzecich szkół podstawowych z małych miejscowości, którzy niejednokrotnie mają utrudniony dostęp do wartościowych programów edukacyjnych. W działania edukacyjne tej edycji programu włączeni zostali również rodzice i nauczyciele oraz osoby z najbliższego otoczenia uczniów.

Zajęcia w ramach programu „ABC zdrowego żywienia” wzbogacone były o dodatkowe materiały edukacyjne dla dzieci, szkół i nauczycieli. Powstały podręczniki metodyczne dla nauczycieli ze scenariuszami lekcji. Przygotowano też aplikację „Zdrowa Apka”, tj. grę edukacyjną dla dzieci, zawierającą również ilustrowaną graficznie encyklopedię z opisami zalecanych i niezalecanych produktów żywnościowych. Działaniom edukacyjnym wszystkich trzech edycji programu towarzyszyły również badania naukowe prowadzone równocześnie we wszystkich ośrodkach akademickich biorących udział w projekcie [Gutkowska i Adamowski 2019, https://www.serwiskorporacyjny.carrefour.pl]. 


\section{Programy edukacji żywieniowej w liczbach}

W trakcie dotychczasowej realizacji (w latach 2006-2019) program „Trzymaj formę!" objął zasięgiem 7200 szkół gimnazjalnych i podstawowych zlokalizowanych na terenie całej Polski. W programie udział wzięło łącznie blisko 9,6 miliona uczniów [Gutkowska i Adamowski 2019]. Wyniki przeprowadzonego w 2013 r. na ponad 11 tys. uczniów monitoringu programu wskazują, że podejmowane działania pozytywnie wpłynęły m.in. na regularne spożywanie śniadań przez uczestników (72\% wskazań) oraz odpowiednią liczbę konsumowanych w ciągu dnia posiłków. Młodzież biorąca udział w programie w porównaniu z rówieśnikami nieobjętymi ww. działaniami, wykazywała również zdecydowanie większą aktywność fizyczną. Przykładowo uczestnicy programu częściej w sposób aktywny docierali do szkoły (np. pieszo lub na rowerze), brali również udział w większej liczbie godzin zajęć wychowania fizycznego tygodniowo oraz mniej czasu przeznaczali na zajęcia sedenteryjne polegające np. na pracy z komputerem lub oglądaniu telewizji. Ponadto znacznie częściej korzystali z obiektów sportowych. Średni wskaźnik masy ciała (BMI), jak również problem nadwagi i otyłości wśród uczestników programu był niższy niż w przypadku respondentów, którzy nie brali udziału w programie. Uczestnicy programu rzadziej również stosowali diety odchudzające [http://www.trzymajforme.pl].

W trakcie trwania „Programu dla szkół” tj. od 2017 r. do końca I semestru roku szkolnego 2019/2020 dzieciom udostępniono łącznie 747,4 mln porcji produktów (z tego $386,7 \mathrm{mln}$ porcji owocowo-warzywnych oraz $360,7 \mathrm{mln}$ porcji mlecznych). W I semestrze roku szkolnego 2019/2020 w programie uczestniczyło 12 tys. szkół podstawowych oraz 1,7 mln dzieci, które stanowiły 94\% grupy docelowej dzieci w całej Polsce. Umowy ze szkołami podpisało 98 zatwierdzonych dostawców owoców i warzyw oraz 107 dostawców mleka i produktów mlecznych [KOWR 2020].

W przypadku programu „ABC zdrowego żywienia” bezpośrednie działania edukacyjne trzech edycji objęły 3183 uczniów oraz 418 osób w wieku powyżej 65 lat z 9 regionów Polski. Jak podkreślają organizatorzy, zakres oddziaływania programu był znacznie szerszy, ponieważ w działania zaangażowane były rodziny osób starszych, a w grupie uczniów nauczyciele, rodzeństwo, rodzice lub opiekunowie oraz rówieśnicy bezpośrednich beneficjentów [Gutkowska i Adamowski 2019].

O powszechności ogólnopolskich programów edukacji żywieniowej świadczą wyniki badań instytutu badawczego ABR SESTA. W 2016 r. w 90\% spośród 400 biorących wudział w ankiecie placówek (szkoły podstawowe, gimnazja i licea) z 15 województw prowadzone były programy z zakresu zdrowego żywienia, w tym aż w 100\% szkół podstawowych. W niemal każdej szkole podstawowej realizowane były programy „Owoce i warzywa w szkole” oraz „Szklanka mleka” [https://www.portalspozywczy.pl/slodyczeprzekaski/wiadomosci/w-szkolach-drastycznie-spadla-sprzedaz-obiadow-i-liczba-sklepikow, 129642_1.html].

Należy jednak pamiętać, iż nieodzownym elementem współczesnych programów edukacji żywieniowej jest ich ewaluacja jak również ciągłe doskonalenie podejmowanych działań. W raporcie instytutu badawczego ABR SESTA podkreślono, że im wyższy szczebel edukacji, tym zaangażowanie w promowanie zdrowego żywienia wśród dzieci i młodzieży spada. W gimnazjach i szkołach ponadgimnazjalnych tego typu akcje odby- 
wają się rzadziej. Programy dotyczące walki z nadwagą i otyłością najczęściej promowane były w gimnazjach (47\%), a następnie w szkołach podstawowych (38\%), ale tylko $18 \%$ szkół ponadgimnazjalnych było nimi zainteresowanych [https://www.portalspozywczy.pl/slodycze-przekaski/wiadomosci/w-szkolach-drastycznie-spadla-sprzedaz-obiadow-i-liczba-sklepikow,129642_1.html ]. Z kontroli Najwyżej Izby Kontroli przeprowadzonej 2017 r. w 20 szkołach, w których realizowane były programy żywieniowe m.in. „Mleko w szkole” oraz „Owoce i warzywa w szkole”, wynika, że warunki organizacyjne w kontrolowanych placówkach nie zawsze sprzyjały osiągnięciu oczekiwanych efektów dla programów. Skuteczność programów żywieniowych osłabiał brak urozmaicenia produktów, przykładowo w programie „Mleko w szkole” spośród wielu możliwych do udostępnienia dzieciom produktów mlecznych serwowane było wyłącznie mleko UHT. Niezrealizowane było również jedno z podstawowych założeń programów, czyli spożywanie otrzymanych produktów na terenie szkoły. Owoce i warzywa na terenie szkoły zawsze spożywało zaledwie 10\% uczniów, a mleko 12,5\% Pozostałe dzieci zabierały produkty do domu, często ich nie konsumując. W opinii rodziców nawyk codziennego spożywania mleka i przetworów mlecznych posiadało jedynie 56,7\%, a owoców tylko 53\% uczniów. Chociaż w szkołach prowadzone były ogólnopolskie programy promujące zdrowe żywienie, nie zatrzymały one tendencji do nieprawidłowej masy ciała wśród uczniów ocenianych placówek [NIK 2017].

\section{Podsumowanie}

Ogólnopolskie programy o długoterminowym charakterze dotyczące edukacji żywieniowej mogą przyczynić się do utrwalania pozytywnych nawyków żywieniowych i kształtowania prozdrowotnego stylu życia. Przyjmuje się, że im wcześniej rozpoczęta edukacja żywieniowa, tym korzystniej, bowiem młody wiek sprzyja formowaniu oraz umacnianiu zachowań żywieniowych, których skutki mogą być odczuwalne przez całe życie. Znakomitym środowiskiem nadającym się do przeprowadzania tego typu interwencji są przedszkola i szkoły, ponieważ umożliwiają docieranie z informacjami do dzieci, ich rodziców, nauczycieli oraz do personelu, a więc jest to działanie kompleksowe. Istotną rolę w prewencji otyłości u dzieci i młodzieży stanowi bowiem wiedza i zachowania żywieniowe rodziców lub opiekunów. Oprócz udostępniania produktów żywnościowych istotną rolę w skutecznej edukacji żywieniowej odgrywają zajęcia, na których wykorzystywane są metody aktywizujące uczestników oraz środki dydaktyczne, które powinny być nie tylko poprawne merytorycznie i dostosowane do percepcji odbiorców, ale także powinny wzbudzać ciekawość, emocje oraz być atrakcyjne wizualnie.

\section{Bibliografia}

Fijałkowska A., 2018. Aktualna ocena poziomu aktywności fizycznej dzieci i młodzieży w wieku 3-19 lat w Polsce. Ministerstwo Sportu i Turystyki, Warszawa.

Gutkowska K., Adamowski J.W., 2019. Edukacja żywieniowa w teorii i praktyce. SGGW, Warszawa.

KOWR 2020. Sprawozdanie z działalności Krajowego Ośrodka Wsparcia Rolnictwa w 2019 roku. Warszawa. 
Matecka M., Głowacka-Rębała A., 2007. Zachowania zdrowotne rodziców a problem otyłości u dzieci. Żyw. Człow. Metab. 34, 991-996.

NFZ 2019. Cukier, otyłość - konsekwencje. Przegląd literatury, szacunki dla Polski. Departament Analiz i Strategii, Narodowy Fundusz Zdrowia, 1-38.

NIK 2017. Wdrażanie zasad zdrowego żywienia w szkołach publicznych. Informacja o wynikach kontroli, 1-54.

Socha J., Stolarczyk A., Socha P., 2002. Zachowania żywieniowe - od genetyki do środowiska społeczno-kulturowego. Nowa Pediatr. 3, 212-217.

Wądołowska L., 2011. Żywieniowe podłoże zagrożeń zdrowia w Polsce. Wydawnictwo UWM w Olsztynie, Olsztyn.

WHO 2020. https://www.who.int/en/news-room/fact-sheets/detail/obesity-and-overweight, [dostęp: 25.03.2021 r.].

Zalewska M., Maciorkowska E., 2012. Rola edukacji żywieniowej w populacji dzieci i młodzieży. Med. Ogólna Nauki Zdr. 19, 375-378.

https://www.portalspozywczy.pl/slodycze-przekaski/wiadomosci/w-szkolach-drastycznie-spadlasprzedaz-obiadow-i-liczba-sklepikow,129642_1.html [dostęp: 25.03.2021 r.]

https://www.programdlaszkol.org [dostęp: 25.03.2021 r.]

https://www.serwiskorporacyjny.carrefour.pl [dostęp: 25.03.2021 r.]

http://www.trzymajforme.pl [dostęp: 25.03.2021 r.] 
Gabriela Gutowska $^{1}$, Kaja Kiersnowska ${ }^{1}$

\section{Związki bioaktywne żywności stosowane w dietoterapii depresji}

Bioactive food compounds used in the diet therapy in depression disease

Według danych z 2017 r. depresja dotyka 322 mln ludzi na całym świecie, co stanowi 4,4\% populacji i sprawia, że jest ona jednym z największych czynników powodujących utratę zdrowia. Objawami towarzyszącymi temu schorzeniu jest niska samoocena, upośledzenie funkcji poznawczych i regulacji emocjonalnej, brak chęci do działania i ból bez wyraźnej przyczyny. Wychodząc naprzeciw tym problemom, w niniejszej pracy podjęto próbę odnalezienia środków zapobiegawczych oraz poprawiających funkcjonowanie już występującej choroby. Okazało się, że prawidłowe odżywienie w dłuższej perspektywie może mieć duże znaczenie, $\mathrm{z}$ uwagi na zmniejszenie stężenia cytokin prozapalnych, których więsze stężenie obserwowane jest w depresji.

\section{Mechanizmy biochemiczne warunkujące powstawanie zaburzeń depresyjnych}

Patogeneza rozwoju depresji nie jest w pełni poznana i wyjaśniona. Mimo zaawansowania medycyny XXI w. naukowcy wciąż badają mechanizmy wpływające na rozwinięcie zaburzeń nastroju. Wykazano, że zachorowanie na depresję jest procesem wieloczynnikowym, nie należy więc pomijać roli genów, przewlekłego stanu zapalnego czy kondycji psychicznej - w tym przebytych traum.

Badania wskazują, że bardzo ważna jest równowaga neuroprzekaźników w mózgu, cząsteczek przekazujących informację pomiędzy komórkami nerwowymi (neuronami), a także innymi komórkami ciała. Głównymi cząsteczkami przekaźnikowymi są serotonina, dopamina oraz noradrenalina. Są to tak zwane monoaminy, a „najpopularniejszą” w kontekście rozwoju depresji jest serotonina zwana inaczej 5-hydroksytryptaminą, której prekursorem jest aminokwas - tryptofan. Jest to tzw. hormon szczęścia, który odpowiedzialny jest za odczuwanie radości, spełnienia czy bezpieczeństwa [Pels 2020].

Dużą rolę w funkcjonowaniu układu nerwowego odgrywa czynnik troficznego pochodzenia mózgowego (ang. brain-derived neurotrophic factor - BDNF). Jest to polipeptydowa cząsteczka należąca do czynników wzrostu, powszechnie występująca w mózgu. Wykazano, że BDNF ma wpływ na powstawanie nowych neuronów i połączeń między nimi, neuroregenerację oraz bierze udział w ochronie już istniejących komórek nerwowych [aan het Rot i in. 2009].

${ }^{1}$ Uniwersytet Przyrodniczy w Lublinie, Wydział Nauk o Żywności i Biotechnologii, kaja.kiersnowska@gmail.com 
Poza neuronami na dużą uwagę zasługują komórki glejowe, a szczególnie astrocyty. Komórki te budują barierę krew-mózg, uczestniczą w przekaźnictwie nerwowym oraz biorą udział w procesach inteligencji. Badania $\mathrm{z}$ lat 90 . wykazały redukcję astrocytów w korze przedczołowej u pacjentów z depresją [Czéh i Nagy 2018]. W innych doświadczeniach zauważono zmniejszanie objętości astrocytów w hipokampie wprost proporcjonalne do długości trwania choroby [Cobb i in. 2016].

Udowodniony wpływ na powstawanie zaburzeń depresyjnych mają czynniki związane ze stresem - komórkowym i psychologicznym. Nadmierna stymulacja osi HPA (podwzgórze-przysadka-nadnercza) jest ściśle powiązana z obecnością przewlekłego stanu zapalnego, którego głównymi wskaźnikami są interleukiny (IL-1, IL-6, IL-10) oraz czynnik martwicy nowotworów $\alpha$ (ang. tumor necrosis factor $\alpha-\mathrm{TNF}-\alpha$ ). Związki te powodują wysoką aktywację osi HPA oraz wpływają na uwrażliwienie receptorów kortykosteroidowych. Równolegle obserwuje się spadek stężenia IL-10 charakteryzującej się właściwościami przeciwzapalnymi. Aktywność TNF- $\alpha$ w rozwoju depresji jest wielopłaszczyznowa, m.in. jest on odpowiedzialny za wzrost aktywności enzymu indoloamino-2,3-dioksygenazy (ang. indoleamine-2,3-dioxygenase - IDO), który kosztem syntezy serotoniny katalizuje reakcje przemiany tryptofanu do kynureniny (szlak kynureninowy), cząsteczki o właściwościach neurotoksycznych. Zjawiskiem występującym w przewlekłym stanie zapalnym jest produkcja reaktywnych form tlenu (ang. reactive oxygen species - ROS). Komórki nerwowe mózgu są wyjątkowo narażone na ich negatywne działanie ze względu na obecność dużej ilości lipidów [Lee i Giuliani 2019].

\section{Wpływ diety i substancji bioaktywnych na zaburzenia depresyjne}

Tolkien i in. [2019] w badaniu dotyczącym wpływu diety przeciwzapalnej na depresję, zauważyli korelację między tym typem odżywiania, a mniejszą częstotliwością występowania objawów typowych dla tej choroby. Kheirouri i Alizadeh [2019] podkreślają związek wzrostu potencjału zapalnego z większym ryzykiem wystąpienia zaburzeń nastroju. Dodatkowo stwierdzono, że dieta przeciwzapalna u osób chorujących na nowotwory i zapalenie stawów, cierpiących z powodu depresji, zmniejsza jej objawy [Miller i Raison 2017]. Liczne badania wykazały, że właściwe odżywianie moduluje stan zapalny ze względu na obecne w niej składniki charakteryzujące się potencjałem przeciwzapalnym. Spożycie produktów pełnoziarnistych wiąże się z niższym stężeniem markerów stanu zapalnego, takimi jak białko C-reaktywne, natomiast ich brak jest skorelowany ze zwiększonym ich poziomem, np. interleukiny-6 [Oddy i in. 2018]. Zwiększone spożycie choliny, która jest składnikiem takich produktów jak: wątróbka, jaja, wieprzowina, brukselka, brokuły, otręby owsiane oraz betainy, występującej w kiełkach pszenicy, krewetkach, szpinaku, grzybach i chlebie pszennym, są związane z niższymi stężeniami markerów stanu zapalnego [Patterson i in. 2008]. Prawdopodobieństwo wystąpienia objawów depresyjnych u osób stosujących dietę prozapalną jest większe o 1,4 w porównaniu $\mathrm{z}$ osobami spożywającymi posiłki bogate w substancje przeciwzapalne [Tolkien i in. 2019]. Przestrzeganie zasad diety śródziemnomorskiej także wiąże się z mniejszym ryzykiem rozwoju tego schorzenia [Lassale i in. 2019]. W badaniu na myszach, u których stosowano ćwiczenia oraz dietę przeciwzapalną wzbogaconą we flawonoidy, zauważono zwiększoną ekspresję genów mających pozytywny wpływ na neuroplastyczność mózgu 
[Van Praag i in. 2007]. Osoby, których dieta bogata jest w żywność przetworzoną (spożywana 5 razy w tygodniu), taką jak: napoje gazowane, fast foody, słodycze, czerwone mięso, są narażone o $39 \%$ bardziej na epizody depresji w porównaniu z osobami, których dieta bazowała na warzywach, owocach i mleku [Meller i in. 2021]. Dodatkowo wykazano, że większe spożycie takich produktów powoduje, że dieta zmienia mikroflorę jelitową, co może mieć negatywne konsekwencje dla mózgu, zwiększając ryzyko rozwoju lub nasilenia depresji [Bear i in. 2020]. W eksperymencie na myszach, których dieta zawierała produkty wysokotłuszczowe, stwierdzono zwiększenie stresu, zachowania podobne do depresyjnych oraz mniejsze stężenie serotoniny w mózgu [Agusti i in. 2018]. Badanie dotyczące korelacji spożycia tłuszczów nasyconych u dzieci ze zmniejszeniem hipokampu, który jest jednym z głównych regionów mózgu dotkniętych tą chorobą, wykazało prawdziwość tej zależności [Stadterman i in. 2020]. Spożycie cukru również może wpływać na występowanie zaburzeń typowych dla tego schorzenia [Marrone i Coccurello 2020]. Częste spożywanie tego typu produktów wiąże się z nadwagą i otyłością, co jest kolejnym czynnikiem zwiększającym ryzyko rozwoju depresji [Ambrósio i in. 2018]. $\mathrm{Z}$ drugiej strony przestrzeganie zaleceń dietetycznych prawidłowego żywienia, dieta przeciwzapalna, spożycie ryb i wykluczenie przetworzonej żywności były związane ze zmniejszeniem podatności na wystąpienie choroby [Ljungberg i in. 2020]. Badania przeprowadzone na dzieciach, młodzieży oraz dorosłych pokazują, że odżywianie na bazie owoców i warzyw daje ten sam efekt [Molendijk i in. 2018]. Zależność ta występuje ze względu na zawartość polifenoli mających silne właściwości przeciwzapalne [Lapuente i in. 2019]. Dodatkowo mogą one wpływać na produkcję neurotroficznego czynnika pochodzenia mózgowego [Neshatdoust $\mathrm{i}$ in. 2016]. Co więcej owoce i warzywa zawierają składniki o działaniu profilaktycznym, takie jak: $\alpha$-tokoferol, witaminy z grupy B, karotenoidy, witamina C, magnez [Meller i in. 2021].

Rośliny strączkowe również wykazują pozytywny wpływ na nastrój, ponieważ zawierają tryptofan, który jest prekursorem serotoniny [Meller i in. 2021]. Rośliny te zawierają również cynk, który działa anagonistycznie dla receptorów NMDA (ang. $N$-methyl-D-aspartate), łączących się z kwasem glutaminowym. Nadmiar glutaminianu może zwiększać objawy charakterystyczne dla tego zaburzenia [Nowak 2015]. W zielonej herbacie występuje galusan epigalokatechiny. Wykazano, że podnosi on poziom BDNF. Inne korzyści płynące ze spożywania zielonej herbaty to wzbogacenie mikrobioty w bakterie z gatunków Lactobacillus i Bifidobacterium. Redukcja odpowiedzi na stres, poprzez znormalizowaną aktywność osi HPA, stanowi główne źródło aktywności przeciwdepresyjnej, w której pośredniczy herbata [Rothenberg i Zhang 2019]. Kawa jest cennym źródłem substancji prozdrowotnych, np. kofeiny [Lucas i in. 2011]. Wykazuje ona właściwości przeciwzapalne i jest przeciwutleniaczem, który charakteryzuje się podobną aktywnością do glutationu, silnego antyoksydantu, pełniącego funkcję ochronną przed uszkodzeniami komórek przez wolne rodniki [Hall i in. 2015]. W kawie występuje wiele polifenoli, do których należą kwas ferulowy, chlorogenowy i kawowy, modulujące parametry zapalenia układu nerwowego [Streit i in. 2004]. Jednym z metabolitów przemian tryptofanu jest kinurenina, która bierze udział w patogenezie depresji. Wyższy poziom kinureniny jest powiązany ze podatnością na występowanie tej choroby, a jej wzrost jest spowodowany dużymi dawkami kofeiny [Hall i in. 2015]. Z drugiej strony w badaniu na 
myszach stwierdzono, że przewlekłe podawanie kofeiny ( $8 \mathrm{mg} / \mathrm{kg} /$ dzień) zwiększyło poziom dopaminy i serotoniny, a tym samym zmniejszyło zaburzenia depresyjne [Tchekalarova i in. 2011]. Wykazano, że kofeina i jeden z jej głównych metabolitów, paraksantyna, hamują wytwarzanie czynnika martwicy nowotworu $\alpha$ (TNF- $\alpha$ ), związanego ze stanem zapalnym [Horrigan i in. 2004]. Ustalono, że kordycepina wyekstrahowana z maczużnika bojowego wpływa korzystnie na deficyty behawioralne wywołane przewlekłym, łagodnym stresem u myszy, który odpowiada objawom podobnym do ludzkich.

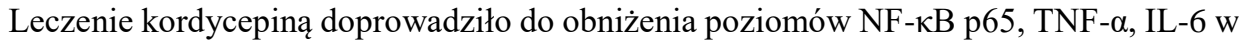
hipokampie myszy. W przeciwieństwie do tego zaobserwowano zwiększenie stężenia serotoniny, dopaminy i neurotroficznego czynnika pochodzenia mózgowego, co zmniejszyło objawy charakterystyczne dla depresji [Tianzhu i in. 2014]. Dziurawiec to zioło, które ma wiele zastosowań, a jednym z nich jest wspomaganie dobrego samopoczucia. Wykazano, że skuteczność dziurawca jest lepsza niż placebo i podobna do innych konwencjonalnych leków, wykorzystywanych w tej przypadłości, a dodatkowo ma mniej skutków ubocznych [Linde i in. 2008]. Hiperforyna, która jest składnikiem dziurawca, jest kluczowym elementem, dzięki któremu obserwuje się jego właściwości przeciwdepresyjne. Wykazano, że ten bioaktywny składnik hamuje wychwyt zwrotny neuroprzekaźników: serotoniny, noradrenaliny i dopaminy [Phillipson 2001]. Najczęściej zgłaszane, choć ogólnie dobrze tolerowane, nieznaczne działania niepożądane to: nudności, wysypka, zmęczenie, niepokój i nadwrażliwość na światło [Ng i in. 2017]. Kolejnym ważnym związkiem wpływającym na nastrój jest fenyloetyloamina, która stanowi modulator neurotransmisji w mózgu i znajduje się w różnych tkankach ssaków. Ma ona związek z wyższymi funkcjami poznawczymi, pamięcią, zapobiega również schizofrenii, depresji, zaburzeniom koncentracji i chorobie Parkinsona. Po spożyciu czekolady zaobserwowano wzrost fenyloetyloaminy, co wiązało się z modulacją nastroju i funkcji poznawczych [Dala-Paula i in. 2021]. Z drugiej strony wysokie jej dawki mogą powodować migreny i wzrost ciśnienia u osób wrażliwych [EFSA 2011]. W niektórych badaniach stwierdzono, że działanie czekolady moduluje ilość serotoniny [Aziz i in. 2011, Guillén-Casla i in. 2012].

\section{Podsumowanie}

Dieta ma istotny wpływ na zaburzenia depresyjne - nieprawidłowa może powodować ich rozwój, natomiast bogata w składniki bioaktywne o właściwościach przeciwzapalnych, może wspomagać farmakoterapię przez zwiększanie poziomu serotoniny i dopaminy. W dietoterapii depresji należy uwzględnić warzywa i owoce, a także produkty pełnoziarniste, które łagodzą stany zapalne. Nie należy pomijać wpływu gorzkiej czekolady, kawy czy ziół, które również mają pozytywne działanie. Dodatkowo prewencyjnie wpływa odstawienie cukru i przetworzonych produktów, takich jak: fast food czy napoje gazowane.

Należy podkreślić, że dieta powinna mieć działanie profilaktyczne lub wspomagające, nie należy traktować jej jako alternatywę do leczenia już występującej choroby. Każde wątpliwości dotyczące kondycji zdrowia psychicznego należy skonsultować z lekarzem psychiatrą. 


\section{Bibliografia}

aan het Rot M., Mathew S.J., Charney D.S., 2009. Neurobiological mechanisms in major depressive disorder. CMAJ 180(3), 305-313. https://doi.org/10.1503/cmaj.080697

Agusti A., Moya-Pérez A., Campillo I., Montserrat-de la Paz S., Cerrudo V., Perez-Villalba A., Sanz Y., 2018. Bifidobacterium pseudocatenulatum CECT 7765 ameliorates neuroendocrine alterations associated with an exaggerated stress response and anhedonia in obese mice. Mol. Neurobiol. 55(6), 5337-535. https://doi.org/10.1007/s12035-017-0768-z

Ambrósio G., Kaufmann F.N. Manosso L., Platt N., Ghisleni G., Rodrigues A.L.S., Rieger D.K., Kaster M.P., 2018. Depression and peripheral inflammatory profile of patients with obesity. Psychoneuroendocrinology 91, 132-141. https://doi.org/10.1016/j.psyneuen.2018.03.005

Aziz N.A.H.A., Al-Muwallad O.K., Mansour E.A.K., 2011. Neurotic depression and chocolate among female medical students at college of medicine, Taibah University Almadinah Almunawwarah, Kingdom of Saudi Arabia. J.Taibah Univ. Med. Sci. 6(2), 139-147. https://doi.org/10.1016/s1658-3612(11)70175-5

Bear T.L.K., Dalziel J.E., Coad J., Roy N.C., Butts C.A., Gopal P.K., 2020. The role of the gut microbiota in dietary interventions for depression and anxiety. Adv. Nutr. 11(4), 890-907. https://doi.org/10.1093/advances/nmaa016

Cobb J.A., O'Neill K., Milner J., Mahajan G.J., Lawrence T.J., May W.L., Miguel-Hidalgo J., Rajkowska G., Stockmeier C.A., 2016. Density of GFAP-immunoreactive astrocytes is decreased in left hippocampi in major depressive disorder. Neuroscience 316, 209-220. https://doi.org/ 10.1016/j.neuroscience.2015.12.044

Czéh B., Nagy S.A., 2018. Clinical findings documenting cellular and molecular abnormalities of glia in depressive disorders. Front Mol Neurosci. 11, 56, https://doi.org/10.3389/fnmol.2018.00056.

Dala-Paula B.M., Deus V.L., Tavano O.L., Gloria M.B.A., 2021. In vitro bioaccessibility of amino acids and bioactive amines in $70 \%$ cocoa dark chocolate: What you eat and what you get. Food Chem. 343, 128397. https://doi.org/10.1016/j.foodchem.2020.128397

EFSA Panel on biological hazards, 2011. Scientific opinion on risk based control of biogenic amine formation in fermented foods. EFSA J. 9(10), 1-93. https://doi.org/10.2903/j.efsa.2011.2393

Guillén-Casla V., Rosales-Conrado N., León-González M.E., Pérez-Arribas L.V., Polo-Díez L.M., 2012. Determination of serotonin and its precursors in chocolate samples by capillary liquid chromatography with mass spectrometry detection. J. Chromatogr. A. 1232, 158-165. https://doi.org/10.1016/j.chroma.2011.11.037

Hall S., Desbrow B., Anoopkumar-Dukie S., Davey A.K., Arora D., McDermott C., Schubert M.M., Perkins A.V., Kiefel M.J., Grant G.D., 2015. A review of the bioactivity of coffee, caffeine and key coffee constituents on inflammatory responses linked to depression. Food Res. Int. 76, 626-636. https://doi.org/10.1016/j.foodres.2015.07.027

Horrigan L.A., Kelly J.P., Connor T.J., 2004. Caffeine suppresses TNF- $\alpha$ production via activation of the cyclic AMP/protein kinase a pathway. Int. Immunopharmacol. 4(10-11), 1409-1417. https://doi.org/ 10.1016/j.intimp.2004.06.005

Kheirouri S., Alizadeh M., 2019. Dietary inflammatory potential and the risk of neurodegenerative diseases in adults. Epidemiol Rev. 41(1), 109-120, https://doi.org/10.1093/epirev/mxz005

Lapuente M., Estruch R., Shahbaz M., Casas R., 2019. Relation of fruits and vegetables with major cardiometabolic risk factors, markers of oxidation, and inflammation. Nutrients 11(10), 2381. https://doi.org/10.3390/nu11102381 
Lassale C., Batty G.D., Baghdadli A., Jacka F., Sánchez-Villegas A., Kivimäki M., Akbaraly T., 2019. Healthy dietary indices and risk of depressive outcomes: a systematic review and meta-analysis of observational studies. Mol Psychiatry. 24(7), 965-986. https://doi.org/10.1038/s41380-018-0237-8

Lee C.H., Giuliani F., 2019. The role of inflammation in depression and fatigue. Front Immunol. 16(1), 22-34. https://doi.org/10.3389/fimmu.2019.01696

Linde K., Berner M.M., Kriston L., 2008. St John's wort for major depression. Cochrane database of systematic reviews (4). https://doi.org/10.1002/14651858.CD000448.pub3

Ljungberg T., Bondza E., Lethin C., 2020. Evidence of the importance of dietary habits regarding depressive symptoms and depression. Int. J. Environ. Res. Public Health 17(5), 1-18. https://doi.org/10..90/ijerph17051616

Lucas M., Mirzaei F., Pan A., Okereke O.I., Willett W.C., O'Reilly É.J., Koenen K., Ascherio A., 2011. Coffee, caffeine, and risk of depression among women. Arch. Intern. Med. 171(17), 1571-1578. https://doi.org/10.1001/archinternmed.2011.393

Marrone M.C., Coccurello R., 2020. Dietary fatty acids and microbiota-brain communication in neuropsychiatric diseases. Biomolecules 10(1). https://doi.org/ 10.3390/biom10010012

Meller F.O., Manosso L.M., Schäfer A.A., 2021. The influence of diet quality on depression among adults and elderly: A population-based study. J. Affect Disord. 282, 1076-1081. https://doi.org/10.1016/j.jad.2020.12.155

Miller A.H., Raison C.L., 2016. Role of inflammation in depression. Nat. Rev. Immunol. 16(1), 22-34. https://doi.org/10.1038/nri.2015.5

Molendijk M., Molero P., Sánchez-Pedreño F.O., Van der Does W., Martínez-González M.A., 2018. Diet quality and depression risk: systematic review and dose-response meta-analysis of prospective studies. J. Affect. Disorders 226, 346-354. https://doi.org/10.1016/j.jad.2017.09.022

Neshatdoust S., Saunders C., Castle S.M., Vauzour D., Williams C., 2016. High-flavonoid intake induces cognitive improvements linked to changes in serum brain-derived neurotrophic factor : two randomised, controlled trials. Nutr. Healthy Aging 4(1), 81-93. https://doi.org/10.3233/NHA-1615

Ng Q.X., Venkatanarayanan N., Ho C.Y., 2017. Clinical use of Hypericum Perforatum (St John's Wort) in depression: a meta-analysis. J. Affect. Disorders 210, 211-221, https://doi.org/10.1016/j.jad.2016.12.048

Nowak G., 2015. Zinc, future mono/adjunctive therapy for depression: mechanisms of antidepressant action. Pharmacol Rep. 67(3), 659-662. https://doi.org/10.1016/j.pharep.2015.01.015

Oddy W.H., Allen K.L., Trapp G.S.A., Ambrosini G.L., Black L.J., Huang R.C., Rzehak P., Runions K.C., Pan F., Beilin L.J., Mori T.A., 2018. Dietary patterns, body mass index and inflammation: Pathways to depression and mental health problems in adolescents. Brain Behav. Immun. 69, 428-439. https://doi.org/10.1016/j.bbi.2018.01.002

Patterson K.Y., Bhagwat S., Williams J.R., Howe J.C., Holden J.M., Zeisel S.H., Dacosta K., Mar M.H., 2004. USDA database for the choline content of common foods. Release One.

Pels K., 2020. O molekularnej patogenezie stresu i depresji. Kosmos 69(1), 169-183. https://doi.org/10.36921/kos.2020_2619

Phillipson J.D., Anderson L.A., Barnes J., 2001. St John's Wort (Hypericum Perforatum L.): A review of its chemistry, pharmacology and clinical properties. J. Pharm. Pharmacol. 53(5), 583600. https://doi.org/10.33974/ijrpps.v1i1.7

Rothenberg D.O, Zhang L., 2019. Mechanisms underlying the anti-depressive effects of regular tea consumption. Nutrients 11(6). https://doi.org/10.3390/nu11061361 
Stadterman J., Belthoff K., Han Y., Kadesh A.D, Yoncheva Y., Roy A.K., 2020. A preliminary investigation of the effects of a western diet on hippocampal volume in children. Front. Pediatr. 8, 58. https://doi.org/10.3389/fped.2020.00058

Streit W.J., Mrak R.E., Griffin W.S.T., 2004. Microglia and neuroinflammation: A pathological perspective. J. Neuroinflammation 1(1), 14. https://doi.org/10.1186/1742-2094-1-14

Tchekalarova, J., Pechlivanova D., Atanasova T., Yakimova K., Nikolov R., 2011. P.1.d.005 depressive-like behaviour of wistar rats exposed to chronic unpredictable stress: effect of longterm caffeine administration. Eur. Neuropsychopharmacol. 21, 292-293. https://doi.org/10.1016/s0924-977x(11)70460-6

Tianzhu Z., Yang S., Du J., 2014. Antidepressant-like effects of cordycepin in a mice model of chronic unpredictable mild stress. Evid. Based. Complement. Alternat. Med. 2014, 1-9. https://doi.org/10.1155/2014/438506

Tolkien K., Bradburn S., Murgatroyd C., 2019. An anti-inflammatory diet as a potential intervention for depressive disorders: a systematic review and meta-analysis. Clin. Nutr. 38(5), 20452052. https://doi.org/10.1016/j.clnu.2018.11.007

Van Praag H., Lucero M.J., Yeo G.W., Stecker K., Heivand N., Zhao C., Yip E., Afanador M., Schroeter H., Hammerstone J., Gage F.H., 2007. Plant-derived flavanol (-)epicatechin enhances angiogenesis and retention of spatial memory in mice. J. Neurosci. 27(22), 5869-5878. https://doi.org/10.1523/JNEUROSCI.0914-07.2007 


\section{Katarzyna Iłowiecka (D)1, Paweł Glibowski (D)1,} Justyna Bochnak-Niedźwiecka (iD)2

\section{Przyczyny i wielowymiarowe konsekwencje otyłości}

Causes and multidimensional consequences of obesity

Według danych Światowej Organizacji Zdrowia (WHO) w 2016 r. ponad 1,9 miliarda dorosłych miało nadwagę, w tym ponad 650 milionów było otyłych [WHO 2021]. Oznacza to, że obecnie blisko 1/3 światowej populacji jest sklasyfikowana jako osoby otyłe lub z nadwagą [GBD 2015]. Jeżeli trend przyrostu liczby osób z otyłością utrzyma się, szacuje się, że do 2050 r. będzie to ok. 50\% populacji [Chooi i in. 2018]. Nadwaga i otyłość są głównymi czynnikami ryzyka wielu chorób przewlekłych, w tym cukrzycy, chorób sercowo-naczyniowych i raka [Hruby i in. 2016]. Kiedyś uważane były za problem tylko w krajach o wysokim dochodzie, jednak dramatycznie rozprzestrzeniają się w regionach o dochodzie niskim i średnim, szczególnie na obszarach wiejskich [Mahase 2019].

Piętno otyłości i związana z nią dyskryminacja zostały udokumentowane w większości kluczowych obszarów życia człowieka. Nadmierna masa ciała pośrednio lub bezpośrednio wpływa na stan zdrowia, dobrostan psychiczny, jakość relacji interpersonalnych czy samoocenę.

\section{Przyczyny rozwoju otyłości}

Otyłość jest chorobą charakteryzującą się nadmiernym nagromadzeniem tkanki tłuszczowej w organizmie, która prowadzi do pogorszenia stanu zdrowia lub stwarza takie ryzyko. Oprócz zbyt wysokiego otłuszczenia ciała do typowych objawów otyłości można zaliczyć m.in.: rozstępy, ginekomastię w przypadku mężczyzn, ograniczoną zdolność ruchu, przewlekły stan zapalny czy zaburzenia stężenia hormonów produkowanych przez adipocyty. Wraz z wiekiem zwiększa się nagromadzenie tkanki thuszczowej wisceralnej (w obrębie jamy brzusznej), redystrybucja tłuszczu do tkanki mięśniowej, natomiast ilość podskórnej tkanki tłuszczowej (m.in. z okolic brzucha, ud i łydek) zmniejsza się [Zamboni i in. 2005]. Nadmierna masa ciała wynikająca z nadwagi i otyłości stała się

\footnotetext{
${ }^{1}$ Uniwersytet Przyrodniczy w Lublinie, Wydział Nauk o Żywności i Biotechnologii, Katedra Biotechnologii, Mikrobiologii i Żywienia Człowieka, katarzyna.ilowiecka1@gmail.com

${ }^{2}$ Uniwersytet Przyrodniczy w Lublinie, Wydział Nauk o Żywności i Biotechnologii, Katedra Biochemii
} 
problemem globalnym, a najnowsze analizy trendów pokazują, że liczba osób z nadwagą lub otyłością stale się zwiększa [Krzysztoszek i in. 2019].

Do klasyfikowania nadwagi i otyłości powszechnie stosowany jest wskaźnik Body Mass Index (BMI), wyrażający masę ciała $(\mathrm{kg})$ podzieloną przez wzrost $(\mathrm{m})$ podniesiony do kwadratu $\left(\mathrm{kg} / \mathrm{m}^{2}\right)$. WHO określa nadwagę jako stan charakteryzujący się zakresem wskaźnika BMI między 25,00 a 29,99 kg/m², natomiast wyznacznikiem otyłości jest wartość BMI większa lub równa $30 \mathrm{~kg} / \mathrm{m}^{2}$ [WHO 1995]. BMI jest łatwe do oszacowania, ponieważ nie wymaga użycia specjalistycznej aparatury, a jedynie podstawowych danych antropometrycznych. Poza indeksem masy ciała kluczowym wskaźnikiem otyłości i nadwagi jest procentowa zawartość tłuszczu w organizmie, gdzie punkty graniczne zgodnie z rekomendacjami WHO wynoszą $>25 \%$ u mężczyzn i $>35 \%$ u kobiet. Kolejnym istotnym parametrem antropometrycznym, na który należy zwrócić uwagę, diagnozując otyłość, jest obwód talii. Jako wartości odcięcia dla nadmiernego nagromadzenia tkanki thuszczowej w okolicach brzucha uważa się wyniki $>94 \mathrm{~cm} \mathrm{u}$ mężczyzn oraz $>80 \mathrm{~cm} \mathrm{u}$ kobiet, co charakteryzuje otyłość brzuszną ze zwiększonym ryzykiem powikłań metabolicznych [WHO 2008].

Według stanowiska WHO główną przyczyną nadwagi i otyłości jest brak równowagi energetycznej między spożywanymi i zużywanymi kaloriami, spowodowany przez zwiększone spożycie wysokokalorycznej żywności bogatej w thuszcz oraz spadek aktywności fizycznej wynikający z nieaktywnego trybu życia, siedzącej pracy, zmieniających się środków transportu i postępującej urbanizacji [WHO 2021]. Na podstawie badań naukowych i obserwacji epidemiologicznych wykazano, że są to dwa najbardziej istotne i bezpośrednie czynniki powodujące nadmierny przyrost masy ciała. Jednak otyłość jest chorobą wieloczynnikową, w rozwoju której udział mają również determinanty genetyczne i środowiskowe.

Predyspozycje genetyczne dodatnio korelujące z ryzykiem wystąpienia otyłości zwykle powiązane są z innymi czynnikami wyzwalającymi lub hamującymi. Jako przykład mogą posłużyć modyfikacje w ekspresji genu FTO, który odgrywa istotną rolę w kontroli przyjmowania pokarmu, regulacji gospodarki energetycznej, rodzaju preferencji żywieniowych czy akumulacji tłuszczów w organizmie [Yeo 2012]. Niekorzystny wariant genetyczny wskazuje na predyspozycje do wystąpienia otyłości i towarzyszących jej chorób przewlekłych (np. choroba wieńcowa, zawał serca, zaburzenia gospodarki węglowodanowej), jednak odpowiednia kompozycja diety może ograniczyć wpływ tego wariantu na wyżej wymienione schorzenia [Merrit $i$ in. 2018].

Kolejnym z czynników, który może wykazywać związek z powstawaniem otyłości jest modyfikacja składu mikrobioty jelitowej. Różnice w składzie mikrobioty osób otyłych i szczupłych monitorowali Ley i in. [2006] Początkowa analiza wykazała, iż dominujący udział mikrobioty osób z obu grup stanowiły gatunki Bacteroides i Firmicutes, przy czym u osób z nadmierną masą ciała grupy Bacterioides było mniej, a Firicutes więcej w porównaniu z grupą kontrolną, którą tworzyły osoby szczupłe. Następstwem stopniowej, rocznej redukcji masy ciała był wzrost liczby Bacterioides i jednoczesny spadek Firmicutes. Na podstawie uzyskanych wyników wysnuto wniosek, iż otyłość jest powiązana ze składem mikrobioty jelitowej, co może mieć potencjalne implikacje terapeutyczne [Ley i in. 2006].

Podczas gdy odsetek otyłych osób zwiększa się we wszystkich grupach społecznoekonomicznych, w niektórych kręgach problem ten jest bardziej nasilony niż w innych. 
Badania naukowe podkreślają złożoność i zmienność w powiązaniu statusu społecznoekonomicznego i otyłości. Analiza danych dla 67 krajów reprezentujących wszystkie regiony świata, która miała określić powiązania rozwoju gospodarczego, statusu społecznoekonomicznego i otyłości, wykazała, że liczba osób otyłych zwiększa się wraz z rozwojem gospodarczym narodów, ale jednocześnie różny jest status socjoekonomiczny związany z otyłością. W krajach o niższych dochodach osoby z wyższym statusem społecznoekonomicznym częściej są otyłe. I odwrotnie, w krajach o wysokim Produkcie Krajowym Brutto (PKB) osoby z wyższymi dochodami są mniej narażone na wystąpienie nadmiernej masy ciała [Pampel i in. 2012]. Różnice w omawianym zagadnieniu uwidaczniają się także w odniesieniu do płci. Kobiety z wyższą pozycją socjoekonomiczną, mają niższe wartości BMI niż kobiety mniej zamożne, podczas gdy wyniki wśród mężczyzn są mniej spójne. Jednym z możliwych powodów takiego stanu rzeczy jest to, że kobiety często mają wyobrażenia o własej masie ciała, które są łatwiejsze do zrealizowania przy wyższym dochodzie, natomiast dla mężczyzn takie ideały mogą nie być istotne. Inną możliwą przyczyną tej różnicy jest rodzaj pracy - mężczyźni o niskim statusie ekonomicznym mogą być bardziej aktywni fizycznie z uwagi na fizyczny rodzaj pracy zawodowej [Newton $\mathrm{i}$ in. 2017].

Szacuje się, że blisko 55\% globalnego wzrostu BMI występuje na obszarach wiejskich, a odsetek ten może sięgać nawet $80 \%$ w krajach o niskim i średnim dochodzie [Bixby i in. 2019]. Obszary wiejskie wiążą się z 1,36 raza większym prawdopodobieństwem wystąpienia otyłości w porównaniu z obszarami miejskimi, jednak wyższe wykształcenie, większy dochód gospodarstwa domowego oraz lepsze sąsiedztwo zmniejszają ryzyko wystąpienia otyłości o 94\% i sprawiają, że ta zależność staje się statystycznie nieistotna [Wen i in. 2018]. Ludność z obszarów wiejskich zazwyczaj ma gorszy dostęp do obiektów sportowo-rekreacyjnych i centrów klinicznych, co może mieć wpływ na zmniejszone praktykowanie profilaktycznych zachowań przeciw otyłości. Szczególnie martwi fakt, że coraz większa jest również liczba dzieci z nadmierną masą ciała, co znacząco zwiększa ryzyko wystąpienia otyłości w wieku dorosłym. Dodatkowo istnieje związek między nadwagą i otyłością w dzieciństwie czy wieku młodzieńczym, a zwiększonym ryzykiem zarówno przedwczesnej zachorowalności, jak i śmiertelności, zwłaszcza na choroby sercowo-naczyniowe [Reilly i Kelly 2010]. Niska świadomość żywieniowa, rozpowszechnianie wysokokalorycznej żywności, które jest tania, w połączeniu z ograniczeniem aktywności fizycznej przyczynia się do utrzymania dodatniego bilansu energetycznego i zwiększenia odsetka otyłych dzieci na obszarach wiejskich [Dong i in. 2019].

\section{Wielowymiarowe konsekwencje nadmiernej masy ciała}

Otyłość jest chorobą, która stanowi istotne zagrożenie dla zdrowia i życia. Stopień otyłości jest dodatnio skorelowany z podwyższonym względnym ryzykiem wystąpienia wielu chorób. Do najistotniejszych i najczęstszych schorzeń powodowanych przez otyłość należą te związane z zaburzeniami układu sercowo-naczyniowego oraz zaburzenia metaboliczne. W tabeli 1 przedstawiono stopień ryzyka występowania chorób u osób otyłych w porównaniu z osobami szczupłymi. 
Tabela 1. Zdrowotne konsekwencje otyłości [Haslam i in. 2006]

\begin{tabular}{|l|}
\hline Znacznie podwyższone ryzyko (trzykrotnie większe ryzyko względne) \\
\hline Cukrzyca \\
Nadciśnienie tętnicze \\
Dyslipidemia \\
Duszność \\
Bezdech senny \\
Choroby pęcherzyka żółciowego \\
\hline Umiarkowanie podwyższone ryzyko (dwu-, trzykrotnie większe ryzyko względne) \\
\hline Choroba wieńcowa lub niewydolność serca \\
Choroba zwyrodnieniowa stawów (zwłaszcza kolan) \\
Hiperurykemia i dna moczanowa \\
Powikłania ciąży - np. stan przedrzucawkowy \\
\hline Zwiększone ryzyko (jedno-, dwukrotnie większe ryzyko względne) \\
\hline Nowotwór (wiele rodzajów u mężczyzn i kobiet) \\
Upośledzona płodnośćlzespół policystycznych jajników \\
Zwiększone ryzyko powikłań podczas znieczulenia \\
Wady płodu wynikające z otyłości matczynej
\end{tabular}

Zwiększona wartość energetyczna diety i niedobór aktywności fizycznej są jednymi z podstawowych czynników zwiększających prawdopodobieństwo przedwczesnej śmierci. Według dostępnych danych w 2017 r. otyłość była przyczyną śmierci blisko 4,72 miliona osób na świecie. To ponad 20-krotnie więcej niż zgonów w wyniku niedożywienia białkowo-energetycznego (głodu) w tym samym roku [Ritchie 2018]. Konsekwencje zdrowotne otyłości mogą dotyczyć wielu narządów, układów i procesów w organizmie, dlatego też podstawowym celem leczenia tych chorób jest zmniejszenie ryzyka wystąpienia schorzeń współtowarzyszących oraz poprawa zaburzeń metabolicznych, czemu istotnie sprzyja redukcja masy ciała [Gajewska 2019].

Rozpowszechnienie otyłości znacznie obciąża krajowe budżety, zwłaszcza w sektorze zdrowia publicznego. W 2016 r. choroby przewlekłe będące skutkami otyłości i nadwagi stanowiły w Stanach Zjednoczonych 480,7 miliarda dolarów bezpośrednich kosztów opieki zdrowotnej, a dodatkowe 1,24 biliona dolarów kosztów pośrednich spowodowanych zmniejszoną wydajnością ekonomiczną ludzi otyłych. Całkowity koszt chorób przewlekłych spowodowanych otyłością i nadwagą wyniósł 1,72 biliona dolarów, co odpowiada 9,3\% PKB w Stanach Zjednoczonych w 2016 r. Otyłość jako czynnik ryzyka jest najistotniejszą determinantą powiązaną z rozwojem chorób przewlekłych, stanowiącą 47,1\% całkowitych kosztów leczenia tych schorzeń w całych Stanach Zjednoczonych [Waters i Graf 2018]. Dane z Europy wskazują, że otyłość każdego roku generuje koszty rzędu 70 miliardów euro, głównie poprzez zwiększone wydatki na opiekę zdrowotną i niższą efektywność pracy [Traill i in. 2013]. Uważa się, że w Europie średnie 
wydatki na opiekę zdrowotną dla osoby otyłej są o $25 \%$ wyższe niż dla osoby o prawidłowej masie ciała [OECD 2010]. Istnieje pilna potrzeba działań na rzecz zdrowia publicznego, skierowanych na profilaktykę i wspomaganie leczenia otyłości, aby oszczędzać zasoby społeczne.

Poza szeregiem negatywnych skutków otyłości w wymiarze zdrowotnym i ekonomicznym, warto nadmienić, iż nadmierna masa ciała utrudnia życie społeczne i może być powiązana z zaburzeniami psychicznymi. Wykazano, że między dorosłymi osobami z nadmierną, a tymi z prawidłową masą ciała istnieją różnice w jakości relacji z partnerami życiowymi, przyjaciółmi i współpracownikami [Carr i Friedman 2006]. Osoby otyłe częściej niż jednostki szczupłe są przedmiotem dyskryminacji ze strony sprzedawców [King i in. 2006], pracodawcy postrzegają je jako osoby o niższych kwalifikacjach [Roehling 1999], a personel medyczny uważa ich za bardziej uciążliwych pacjentów [Hebl i Xu 2001]. W kontekście zdrowia psychicznego wydaje się, że otyłość jest związana ze zwiększonym odsetkiem zaburzeń psychicznych, zwłaszcza zaburzeń lękowych zarówno wśród kobiet, jak i mężczyzn [Becker i in. 2001, Hach i in. 2007]. Dodatkowo dowody naukowe kładą nacisk na zwiększające się ryzyko niskiej samooceny, zaburzeń nastroju, zaburzeń motywacji, problemów z jedzeniem, upośledzonego obrazu ciała, problemów z komunikacją interpersonalną u osób otyłych, co bezpośrednio lub pośrednio pogarsza jakość życia [Rajtan i Menon 2017]. Przy czym w świetle obecnej wiedzy nie do końca wiadomo, czy rozwój zaburzeń psychicznych jest przyczyną czy skutkiem nadmiernej masy ciała. Nie wyklucza się, że zależność ta może mieć charakter dwukierunkowy [Łuszczyńska 2007].

\section{Cele leczenia dietetycznego otyłości u dorosłych}

Spośród osób, które dietą zredukowały masę ciała, jedynie $20 \%$ potrafi utrzymać uzyskany efekt przynajmniej przez kolejny rok [Wing i Phelan 2005]. Z tego względu warto szukać skutecznych rozwiązań, które pomogą w długoterminowym zarządzaniu masą ciała po zakończonej dietoterapii. Celem praktycznym dietetycznego leczenia otyłości jest uzyskanie i długoterminowe (min. dwa lata) utrzymanie masy ciała zmniejszonej o 5-10\% w odniesieniu do masy początkowej. Osiągnięcie takiego rezultatu pociąga za sobą szereg korzyści zdrowotnych, do których zalicza się m.in.: redukcję o ok. $10 \mathrm{~mm}$ Hg ciśnienia krwi, redukcję o 10\% cholesterolu całkowitego czy zmniejszenie o 20\% ogólnej śmiertelności [Haslam i in. 2006, Gajewska 2019]. Jak wykazali Foster i in. [1997] taki efekt nie byłby satysfakcjonujący dla otyłych pacjentów, gdyż ich średnie wyobrażenia na temat żądanej utraty masy ciała oscylują w granicach $-38,4 \%$, co często nie jest możliwe do osiągnięcia. Dlatego warto zwracać uwagę, iż nawet niewielka redukcja masy ciała niesie za sobą pozytywne skutki zdrowotne.

U pacjentów z grupy wysokiego ryzyka chorób układu krążenia zmniejszenie i utrzymanie masy ciała o 3-5\% przynosi istotną poprawę wskaźników gospodarki lipidowej i węglowodanowej [Gajewska 2019]. 


\section{Podsumowanie}

Otyłość i jej skutki w różnych wymiarach życia należy uznać za jeden z najważniejszych obecnie priorytetów zdrowia publicznego. Istnieje potrzeba opracowania kompleksowych strategii leczenia, zapobiegania i kontroli tej epidemii.

\section{Bibliografia}

Bixby H., Bentham J., Zhou B., Di Cesare M., Paciorek C. J., Bennett J. E. i in., 2019. NCD Risk Factor Collaboration (NCD-RisC). Rising rural body-mass index is the main driver of the global obesity epidemic in adults. Nature 569 (7755), 260-264. https://doi.org/10.1038/s41586019-1171-x

Becker E.S., Margraf J., Türke V., Soeder U., Neumer S., 2001. Obesity and mental illness in a representative sample of young women. Int. J. Obes. Relat. Metab. Disord. J. Int. Assoc. Study Obes. 25 Suppl 1, S5-9. https://doi.org/10.1038/sj.ijo.0801688

Carr D., Friedman M.A., 2006. Body weight and the quality of interpersonal relationships. Soc. Psychol. Q. 69(2), 127-149. https://doi.org/10.1177/019027250606900202

Chooi Y.C., Ding C., Magkos F., 2019. The epidemiology of obesity. Metabolism 92, 6-10. https://doi.org/10.1016/j.metabol.2018.09.005

Dong Y., Ma Y., Dong B., Zou Z., Hu P., Wang Z., Yang Y., Song Y., Ma J., 2019. Geographical variation and urban-rural disparity of overweight and obesity in Chinese school-aged children between 2010 and 2014: two successive national cross-sectional surveys. BMJ Open 9(4), e025559. https://doi.org/10.1136/bmjopen-2018-025559

Foster G.D., Wadden T.A., Vogt R.A., Brewer G., 1997. What is a reasonable weight loss? Patients' expectations and evaluations of obesity treatment outcomes. J. Consult. Clin. Psychol. 65(1), 79-85. https://doi.org/10.1037//0022-006x.65.1.79

Gajewska D., Myszkowska-Ryciak J., Lange E., Gudej S., Pałkowska-Goździk E., Bronkowska M., Piekło B., Łuszczki E., Kret M., Białek-Dratwa A., Pachocka L., Sobczak-Czynsz A., 2019. Standardy leczenia dietetycznego otyłości prostej u osób dorosłych - Stanowisko PTD 2019. J. Diet. 8, 1-24.

Global Burden of Disease Study (GBD), 2015. Obesity and overweight prevalence 1980-2015. GHDx. http://ghdx.healthdata.org/record/ihme-data/gbd-2015-obesity-and-overweight-prevalence-1980-2015 [dostęp 12.02.2021]

Hach I., Ruhl U.E., Klose M., Klotsche J., Kirch W., Jacobi F., 2007. Obesity and the risk for mental disorders in a representative german adult sample. Eur. J. Public Health. 17(3), 297-305. https://doi.org/10.1093/eurpub/ckl227

Haslam D., Sattar N., Lean M., 2006. Obesity - time to wake up. BMJ 333(7569), 640-642 https://doi.org/10.1136/bmj.333.7569.640

Hebl M.R., Xu J., 2001. Weighing the care: physicians' reactions to the size of a patient. Int. J. Obes. Relat. Metab. Disord. J. Int. Assoc. Study Obes. 25(8), 1246-1252. https://doi.org/10.1038/sj.ijo.0801681

Hruby A., Manson J.E., Qi L., Malik V.S., Rimm E.B., Sun Q., Willett W.C., Hu F.B., 2016. Determinants and consequences of obesity. Am. J. Public Health 106(9), 1656-1662. https://doi.org/10.2105/AJPH.2016.303326

King E.B., Shapiro J.R., Hebl M.R., Singletary S.L., Turner S., 2006. The stigma of obesity in customer service: A mechanism for remediation and bottom-line consequences of interpersonal discrimination. J. Appl. Psychol. 91(3), 579-593. https://doi.org/10.1037/0021-9010.91.3.579

Krzysztoszek J., Laudańska-Krzemińska I., Bronikowski M., 2019. Assessment of epidemiological obesity among adults in EU countries. Ann. Agric. Environ. Med. 26(2), 341-349. https://doi.org/10.26444/aaem/97226 
Ley R.E., Turnbaugh P.J., Klein S., Gordon J.I., 2006. Human gut microbes associated with obesity. Nature 444(7122), 1022-1023. https://doi.org/10.1038/4441022a

Łuszczyńska A., 2007. Nadwaga i otyłość. Interwencje psychologiczne. PWN, Warszawa.

Mahase E., 2019. Obesity rates are increasing more rapidly in rural areas than in cities. BMJ. 365, 12088. https://doi.org/10.1136/bmj.12088

Merritt D.C., Jamnik J., El-Sohemy A., 2018. FTO genotype, dietary protein intake, and body weight in a multiethnic population of young adults: a cross-sectional study. Genes Nutr. 13, 4. https://doi.org/10.1186/s12263-018-0593-7

Newton S., Braithwaite D., Akinyemiju T.F., 2017. Socio-economic status over the life course and obesity: systematic review and meta-analysis. PloS One. 12(5), e0177151. https://doi.org/10.1371/journal.pone.0177151

OECD, 2010. Obesity and the economics of prevention: fit not fat, OECD Publishing, Paris, https://doi.org/10.1787/9789264084865-en [dostęp 12.02.2021]

Pampel F.C., Denney J.T., Krueger P.M., 2012. Obesity, SES, and economic development: a test of the reversal hypothesis. Soc. Sci. Med. 74(7), 1073-1081. https://doi.org/10.1016/j.socscimed.2011.12.028

Rajan, T.M., Menon V., 2017. Psychiatric disorders and obesity: a review of association studies. J. Postgrad. Med. 63(3), 182-190. https://doi.org/10.4103/jpgm.JPGM_712_16

Reilly J.J., Kelly J., 2011. Long-term impact of overweight and obesity in childhood and adolescence on morbidity and premature mortality in adulthood: systematic review. Int. J. Obes. 35(7), 891-898. https://doi.org/10.1038/ijo.2010.222

Ritchie H., Roser M., 2018. Causes of death. Our world data 2018. https://ourworldindata.org/causes-of-death [dostęp 15.03.2021]

Roehling M.V., 1999. Weight-based discrimination in employment: psychological and legal aspects. Pers. Psychol. 52(4), 969-1016. https://doi.org/10.1111/j.1744-6570.1999.tb00186.x

Traill W.B., Mazzocchi M., Niedźwiedzka B., Shankar B., Wills J., 2013. The EATWELL project: recommendations for healthy eating policy interventions across Europe. Nutr. Bull. 38(3), 352-357. https://doi.org/10.1111/nbu.12048

Waters H., Graf M., 2018. America's obesity crisis: The health and economic costs of excess weight. Milken Institute Report. https://milkeninstitute.org/report/americas-obesity-crisis-healthand-economic-costs-excess-weight [dostęp 12.02.2021]

Wen M., Fan J.X., Kowaleski-Jones L., Wan N., 2018. Rural-urban disparities in obesity prevalence among working age adults in the United States: exploring the mechanisms. Am. J. Health Promot. 32(2), 400-408. https://doi.org/10.1177/0890117116689488

WHO, 1995. The use and interpretation of anthropometry. Report of a WHO Expert Committee. World Health Organization, Geneva.

WHO, 2008. Waist circumference and waist-hip ratio: report of a WHO expert consultation. https://www.who.int/publications-detail-redirect/9789241501491 [dostęp 12.02.2021]

WHO, 2021, Obesity and overweight. https://www.who.int/news-room/fact-sheets/detail/obesity-and-overweight [dostęp 12.02.2021]

Wing R.R., Phelan S., 2005. Long-term weight loss maintenance. Am. J. Clin. Nutr. 82(1 Suppl), 222S-225S. https://doi.org/10.1093/ajcn/82.1.222S

Yeo G.S.H., 2012. FTO and obesity: a problem for a billion people. J. Neuroendocrinol. 24(2), 393-394. https://doi.org/10.1111/j.1365-2826.2011.02254.x

Zamboni M., Mazzali G., Zoico E., Harris T. B., Meigs J. B., Di Francesco V., Fantin F., Bissoli L., Bosello O., 2005. Health consequences of obesity in the elderly: a review of four unresolved questions. Int. J. Obes. 29(9), 1011-1029, https://doi.org/10.1038/sj.ijo.0803005 


\section{Stosowanie żywności jako formy nagradzania i/lub karania dzieci w wieku przedszkolnym}

Using food as a form of reward and/or punishment children of pre-school age

Jednym z najczęściej popełnianych przez rodziców i/lub opiekunów błędem jest wychowywanie dziecka poprzez system nagród i kar w formie jedzenia. Mimo że forma ta jest skuteczna, z pewnością nie stanowi właściwej metody wychowawczej. Przez system nagród i kar dziecko utożsamia konkretne emocje, w tym przypadku z produktami żywnościowymi. Zapoczątkowuje to tzw. ,jedzenie emocjonalne”, przez które dziecko w życiu dorosłym pod wpływem konkretnych uczuć może sięgać po jedzenie. Zachowania takie są podświadomie głęboko zakorzenione i mogą nieść ze sobą negatywne konsekwencje.

Z pedagogicznego punktu widzenia nagroda i kara stosowana wobec dziecka w sposób prawidłowy, z towarzyszącą im refleksją i badaniem przyczyn danego zachowania dziecka, skutkują osiągnięciem zamierzonych celów wychowawczych. Kara musi być logiczna i równomierna $\mathrm{z}$ występkiem dziecka. Istnieje wiele bardziej skutecznych form nagradzania niż jedzenie, które bez wątpienia jest złym wyborem. W zamian za to dziecko można nagrodzić pochwałą słowną bądź wspólnym spędzaniem czasu na czynnościach lubianych przez dziecko.

Zarówno negatywne, jak i pozytywne emocje wpływają na wybór określonych pokarmów w różnych warunkach [Glibowski i Misztal 2016]. Przykładowo odpowiadają za lubienie lub nielubienie pewnych produktów spożywczych, np. czekolady [Kwiatkowska i in. 2017].

\section{Cel i hipotezy badawcze}

Celem pracy było zbadanie opinii rodziców dzieci w wieku przedszkolnym (do 6 . roku życia) na temat stosowania różnych rodzajów żywności jako formy dyscyplinowania dzieci (kary i/lub nagrody). Zapytano także o to, czy respondenci zetknęli się z takimi zachowaniami w stosunku do siebie lub stosowali je u własnych dzieci.

Założono dwie hipotezy badawcze:

- rodzice z wykształceniem wyższym z racji większej ogólnej wiedzy na temat żywienia będą rzadziej stosowali żywność jako nagrodę i/lub karę;

- rodzice, którzy jako dzieci byli nagradzani i/lub karani jedzeniem, wobec swoich dzieci również będą stosowali taką metodę wychowawczą.

\footnotetext{
${ }^{1}$ Uniwersytet Przyrodniczy w Lublinie, Wydział Nauk o Zwierzętach i Biogospodarki, karolina.jachimowicz@up.lublin.pl
} 


\section{Materiały i metody}

Badania zostały przeprowadzone metodą ankietową w $2020 \mathrm{r}$. W anonimowej ankiecie udział wzięło 225 rodziców dzieci do lat 6 . Autorski kwestionariusz ankiety składał się z 30 pytań. Kwestionariusz został podzielony na dwa bloki tematyczne: żywność jako nagroda oraz żywność jako kara. Większość pytań miało formę zamkniętą, ankieta zawierała jedynie dwa pytania otwarte wymagające krótkiej odpowiedzi (wzrost oraz masa ciała dziecka). W ankiecie pytano o postaci, w jakich przyznawana jest nagroda i/lub kara, o sytuacje, w jakich rodzic stosuje żywność jako nagrodę i/lub karę oraz jak często to robi. W ankiecie pytano również, czy rodzic uważa, że stosowanie nagrody i/lub kary jest prawidłowe, oraz jakie są spodziewane skutki tej metody wychowawczej w sposobie odżywiania się dziecka w wieku dorosłym.

$\mathrm{Na}$ podstawie otrzymanych danych antropometrycznych dzieci wyliczono ich współczynnik BMI. Otrzymane wyniki zinterpretowano na podstawie siatek centylowych [Bilewicz-Wyrozumska i in. 2015].

Wykresy przedstawiające wyniki przygotowano w programie Microsoft Excel. $\mathrm{Z}$ wykorzystaniem programu Statistica 13.1. oceniono różnice istotne statystycznie $(\mathrm{P}<0,05)$, stosując test Duncana.

\section{Wyniki i dyskusja}

\section{Charakterystyka badanej populacji rodziców oraz dzieci}

W większości odpowiedzi na pytania udzieliły matki (81\%). Największy odsetek ankietowanych stanowili rodzice w przedziale wiekowym 26-35 lat (38\%). Zdecydowana większość osób (84\%) miała wykształcenie wyższe (ryc. 1).

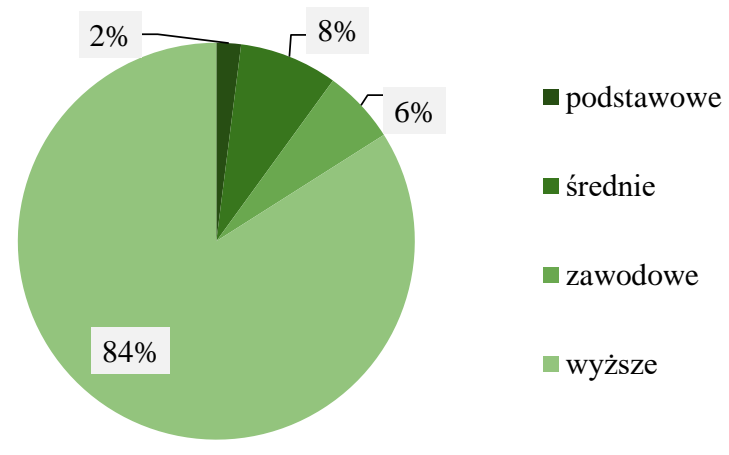

Ryc. 1. Wykształcenie rodzica

Wśród dzieci będących przedmiotem ankiety więcej było chłopców (52\%). Rozkład wieku dzieci został przedstawiony na rycinie 2 . Na podstawie otrzymanych pomiarów 
antropometrycznych dzieci wyliczono współczynniki BMI i naniesiono je na siatki centylowe odpowiednie dla płci. Większość dzieci (59\%) miała prawidłową masę ciała. Pozostałe dzieci charakteryzowały się niedowagą ( $28 \%)$, nadwagą (10\%) oraz nieliczni otyłością (3\%).

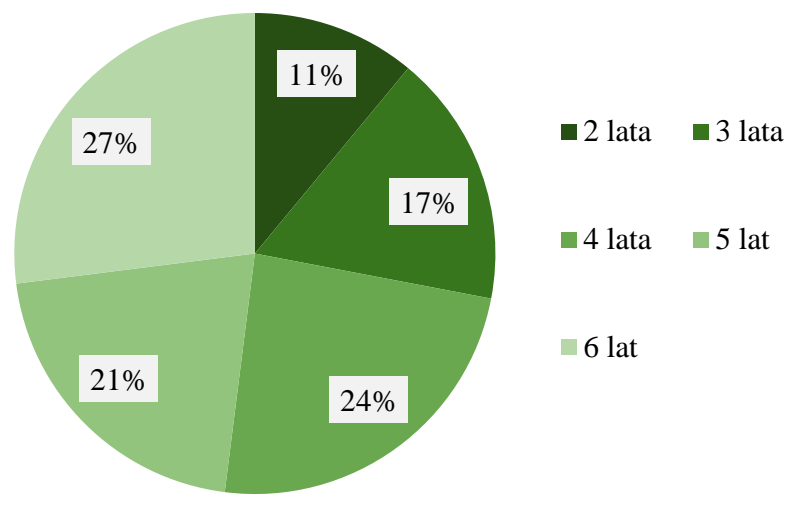

Ryc. 2. Wiek dzieci

\section{Żywność jako nagroda}

Wśród ankietowanych rodziców 75\% zadeklarowało, iż nie stosuje żywności jako nagrody dla swojego dziecka. Na pytanie „Czy inne osoby w Pana/Pani rodzinie stosują żywność jako nagrodę dla dziecka” większość (65\%) odpowiedziała „nie”, 18\% odpowiedziało twierdząco, natomiast aż $17 \%$ rodziców nie wiedziało, czy ktoś z ich bliskich nagradza dziecko jedzeniem. Najczęstszym produktem żywnościowym stosowanym przez rodziców do nagradzania dziecka za jego zachowanie była czekolada oraz obietnica wyjścia na lody. Najmniej rodziców nagradzało dziecko owocem, wyjściem do restauracji oraz przyrządzeniem na obiad ulubionej potrawy dziecka. Szczegółowe odpowiedzi zostały przedstawione na rycinie 3 . W badaniu ankietowym przeprowadzonym przez Rasińską i Głowacką-Rębałę [2013] najczęściej stosowaną nagrodą żywieniową również była czekolada $(52,3 \%)$ oraz lody $(29,5 \%)$. Cytowane autorki zwracają uwagę, że rodzice nie powinni traktować słodyczy jako nagrody, ponieważ może to doprowadzić do wytworzenia nieprawidłowych nawyków żywieniowych. Bardzo często rodzice pocieszają dzieci słodyczami, kiedy te zmagają się z trudnościami. Prowadzi to do przeświadczenia, że słodycze wyeliminują nieprzyjemne uczucia i należy sięgać po nie w trudnych chwilach [Puhl i Schwartz 2003].

W pytaniu „W jakich sytuacjach stosuje Pan/Pani żywność jako nagrodę” wśród osób stosujących taką formę wychowawczą liczba odpowiedzi była do siebie zbliżona $33 \%$ rodziców przez nagrodę nakłaniało dziecko do zjedzenia posiłku, 31\% nagradzało w ten sposób samodzielność dziecka w codziennych czynnościach, a 36\% premiowało w ten sposób sprzątanie zabawek. Brak wyraźnego zróżnicowania w odpowiedziach może świadczyć o tym że rodzic, który nagradza dziecko jedzeniem, chcąc wyegzekwować od niego pewne zachowania, jednocześnie napotykając przy tym opór z jego strony, będzie stosował taką formę wychowawczą w wielu różnych sytuacjach dnia codziennego. Według Rasińskiej i Głowackiej-Rębały [2013] najczęściej dzieci są nagradzane słodyczami 
za dobre oceny $(36,4 \%)$ oraz właściwe zachowanie $(34,1 \%)$. Jednak takie zachowania prowadzą do odwrotnych skutków, wzmacniając tym samym u dziecka pozytywne znaczenie niskogatunkowej żywności [Puhl i Schwartz 2003].
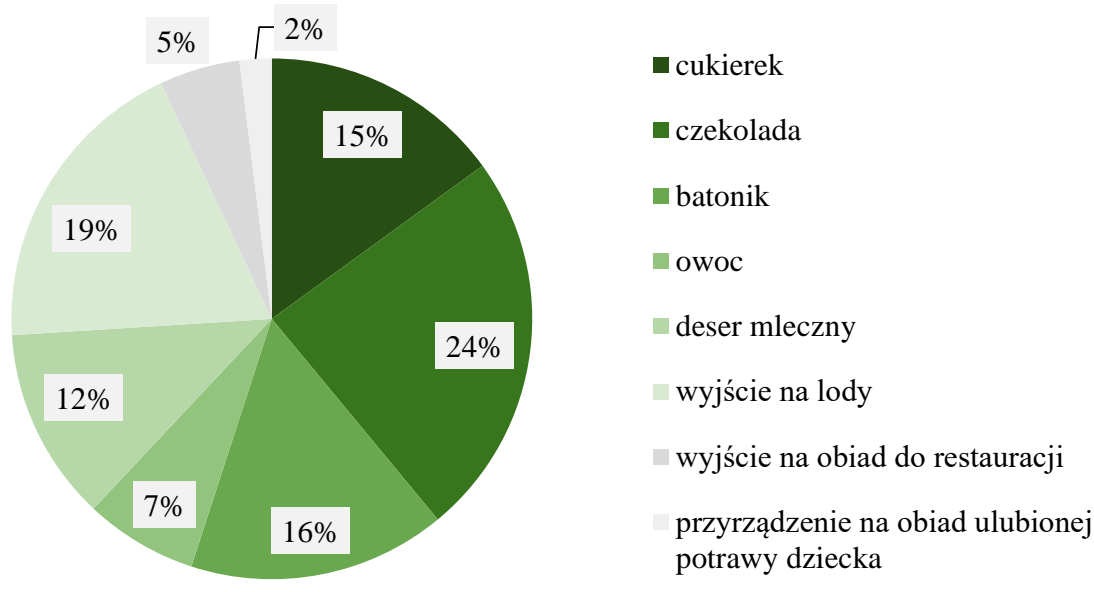

Ryc. 3. Najczęściej stosowane nagrody

Częstotliwość stosowania jedzenia jako formy nagradzania dziecka była zróżnicowana (ryc. 4). Najczęściej rodzice, których to zagadnienie dotyczyło deklarowali, że nagradzają swoje dzieci żywnością kilka razy w tygodniu. W badaniu Rasińskiej i Głowackiej-Rębały [2013] ankietowani odpowiadali, że stosują nagrody wobec dzieci dość często $(36,4 \%)$ oraz często $(27,3 \%)$.

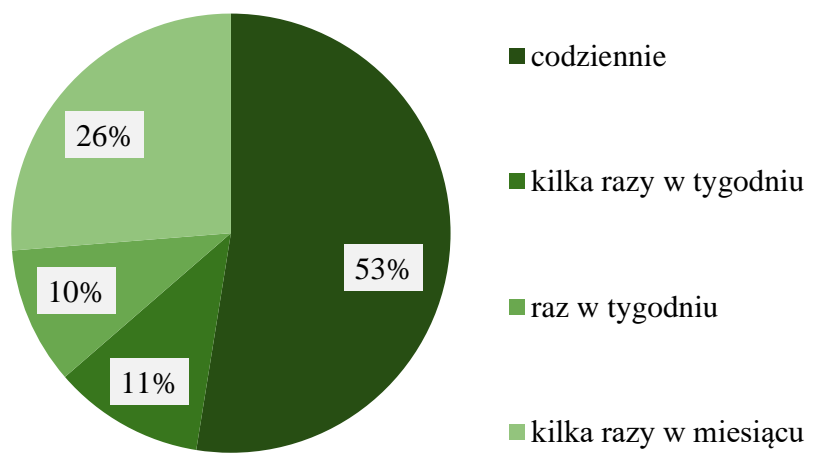

Ryc. 4. Częstotliwość nagradzania dziecka żywnością 
Zdecydowana większość rodziców (75\%) twierdziła, iż stosowanie żywności jako nagrody dla dziecka jest nieprawidłowe. Mimo to $90 \% \mathrm{z}$ nich stosowało taką formę wychowawczą, ponieważ jest ona skuteczna i dzięki niej osiągają swoje cele. Według pozostałych rodziców nagradzanie było nieskuteczne lub niezauważalne (po 5\% odpowiedzi). Nagroda często stanowi jedyną skuteczną formę wychowawczą. Głównie sprawdza się w przypadku małych dzieci, z którymi rodzice mają problemy wychowawcze [Frączek 2014].

Na pytanie „Jakie skutki przynosi nagradzanie dziecka?” rodzice stosujący tę formę dyscyplinowania odpowiadali w zróżnicowany sposób. Część z nich zaznaczyła jedynie pozytywne skutki nagradzania, a druga część rodziców twierdziła, że skutki mogą być zarówno pozytywne, jak i negatywne. W konsekwencji więcej rodziców uważało, iż nagradzanie daje pozytywne skutki (53\%). Według Kluz [2011] nagradzanie dziecka ma więcej pozytywnych skutków niż karanie. Badania Puhl i Schwartz [2003] wykazały, że podanie dziecku w nagrodę deseru jest skuteczną metodą zachęcania go do próbowania nowych produktów żywnościowych. Ponadto stwierdzono, że dzieci chętniej wybierają pokarm, który został wykorzystany wcześniej jako nagroda.

Rodzice nienagradzający dzieci jedzeniem uważali, że nagradzanie mogłoby mieć w przyszłości negatywne skutki w ich sposobie odżywiania, objawiające się m.in. nadmierną masą ciała bądź zaburzeniami odżywiania. Według 19\% rodziców pochwalających tę formę nagradzania nie ma ona negatywnych skutków. Stosowanie żywności jako nagrody i/lub kary w celach kontrolowania zachowania dziecka może prowadzić do problemów z przystosowaniem się do prawidłowych zachowań żywieniowych w życiu dorosłym. Badania mówią, iż w przypadku młodzieży cierpiącej na zaburzenia odżywiania w tym na bulimię, stosowana była wcześniej żywność jako nagroda za dobre zachowanie i sukcesy [Puhl i Schwartz 2003]. Częściej żywność jako nagrodę wykorzystują autorytatywni rodzice, skłonni do tego, żeby regulować emocje dzieci oraz ilość i jakość spożywanego przez nie pokarmu w celu kontrolowania masy ciała [Van der Horst i Sleddens 2017].

\section{Żywność jako kara}

Struktura odpowiedzi na pytanie „Czy stosuje Pan/Pani żywność jako karę dla swojego dziecka?” była identyczna jak w pytaniu o stosowanie żywności jako nagrody. Znaczna większość ankietowanych odpowiedziała, iż tego nie robi (76\%), natomiast pozostali stosowali żywność jako karę. Brak dużego zróżnicowania w odpowiedziach wskazuje, iż rodzic, który wykorzystuje żywność jako formę wychowawczą, stosuje ją zwykle zarówno jako nagrodę, jak i karę. W badaniu przeprowadzonym przez Kowolika [2011] $62,5 \%$ ankietowanych przyznało, że stosuje nagrody jako środki wychowawcze dzieci, natomiast zaledwie $12,5 \%$ stosowało kary.

Na pytanie „Czy inne osoby w Pana/Pani rodzinie stosują żywność jako karę dla dziecka" ankietowani również udzielili bardzo zbliżonych odpowiedzi w porównaniu z pytaniem o nagradzanie dziecka żywnością. Większość (66\%) odpowiedziała ,nie”, natomiast po $17 \%$ rodziców odpowiedziało twierdząco bądź nie wiedziało, czy ktoś z ich bliskich karze dziecko jedzeniem. Wśród osób stosujących dyscyplinowanie dzieci za 
pomocą jedzenia większość rodziców jako karę praktykowała niepodanie dziecku produktu żywnościowego (61\%). Mniejsza część rodziców nie zgadzała się na wyjścia do restauracji (39\%).

W pytaniu „W jakich sytuacjach stosuje Pan/Pani żywność jako karę dla swojego dziecka" stosunek odpowiedzi był do siebie zbliżony, podobnie jak w pytaniu w części ankiety o nagradzaniu. Odsetek $38 \%$ ankietowanych rodziców karał swoje dzieci za brak posłuszeństwa, $32 \%$ za nieuprzątnięcie zabawek, zaś $31 \%$ za niezjedzenie całej porcji obiadu.

Ponad połowa ankietowanych karała swoje dzieci wykorzystując żywność kilka razy w tygodniu (58\%), co przedstawia rycina 5. Opinia oraz wiedza rodziców na temat prawidłowości stosowania żywności jako kary była taka sama, jak w stosunku do stosowania żywności jako nagrody. Zdecydowanie większość rodziców (75\%) uważała, iż stosowanie żywności jako kary dla dziecka jest nieprawidłowe, natomiast 9\% ankietowanych uważało wprost przeciwnie. Reszta rodziców (16\%) nie miała zdania, bądź wiedzy na ten temat. Zdaniem Kluz [2011] umiejętnie stosowana kara powoduje osiągnięcie dojrzałej osobowości u dziecka oraz uczy postaw moralnych. Kara ma za zadanie eliminowanie niewłaściwych zachowań, natomiast nagrodę stosuje się po to, żeby prawidłowe zachowania utrwalały się.

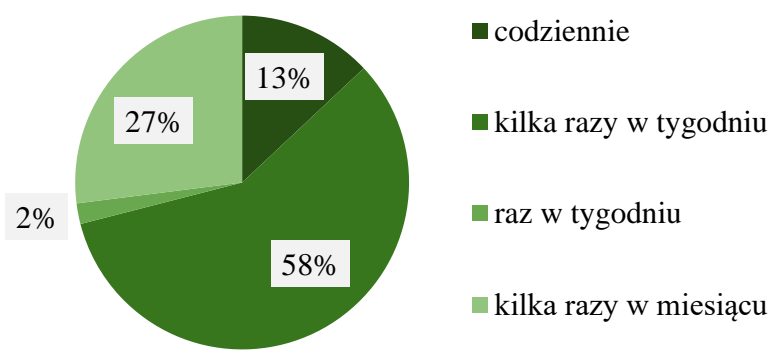

Ryc. 5. Częstotliwość karania dziecka żywnością

W przypadku karania skuteczność była równie wysoka jak w nagradzaniu dziecka jedzeniem. Wśród osób stosujących żywność jako sposób dyscyplinowania aż 91\% przyznało, że taka forma wychowawcza przynosi pożądane efekty w zachowaniu dziecka. Pozostali rodzice nie odnotowali żadnych zmian bądź udzielili odpowiedzi "nie wiem".

Na pytanie „Jakie skutki przynosi karanie dziecka” schemat odpowiedzi rodziców był przybliżony do odpowiedzi dotyczących skutków nagradzania dziecka jedzeniem. $\mathrm{Z}$ uwagi na większy odsetek rodziców stosujących żywność jako nagrodę okazało się, że $54 \%$ ankietowanych uważało, że karanie przynosi negatywne skutki. Do niekorzystnych skutków karania zalicza się utratę zaufania, zmęczenie psychiczne oraz napięcie wywołane lękiem [Frączek 2014].

Rodzice niekarzący dzieci jedzeniem uważali, że karanie mogłoby mieć w przyszłości negatywne skutki w ich sposobie odżywiania. W przypadku rodziców pochwala- 
jących tę formę wychowawczą ponad 20\% uznało, że nie ma negatywnych skutków karania. Od wielu lat badania pokazują, iż dzieci, które były nagradzane i/lub karane żywnością, mają większe skłonności do objadania się lub wprost przeciwnie - do stosowania restrykcyjnej diety [Puhl i Schwartz 2003]. Wiele wyników badań potwierdza, że dzieci takie wykazują również zaburzenia emocjonalne oraz związane $\mathrm{z}$ frustracją problemy z uczeniem się [Fedewa i Davis 2015]. Co więcej Vandeweghe i in. [2016] stwierdzili, że unikanie przez małe dzieci niektórych potraw, a nawet jedzenia w ogóle, może być konsekwencją stosowania przez ich opiekunów żywności jako kary, natomiast nadmierne jedzenie niektórych pokarmów może być związane z tym, że są one stosowane jako nagroda.

W badaniach własnych zdecydowana większość rodziców (72\%) uważała, że dzieci mogą nabyć prawidłowe nawyki żywieniowe oraz wychowawcze bez konieczności stosowania nagród i kar. Głównie byli to rodzice nie stosujący tej formy dyscyplinowania wobec własnych dzieci. Odpowiedź „nie” (13\%) zaznaczali głównie rodzice stosujący system nagród i kar. Wynikać to może ze skuteczności nagród i kar oraz braku efektów w przypadku zastosowania innych metod wychowawczych. Natomiast $15 \%$ ankietowanych odpowiedziało ,nie wiem”. Część tę stanowili rodzice zarówno stosujący nagrody i kary, jak i ci, którzy tego nie robili.

Większość ankietowanych rodziców (58\%) nie była ani nagradzana, ani karana jedzeniem w dzieciństwie (ryc 6). W pozostałych odpowiedziach nie ma znaczącej różnicy, co potwierdza wcześniej zaobserwowaną korelację, tj. jeżeli rodzic stosuje żywność w celach wychowawczych, wykorzystuje ją zarówno do nagradzania, jak i ukarania dziecka.

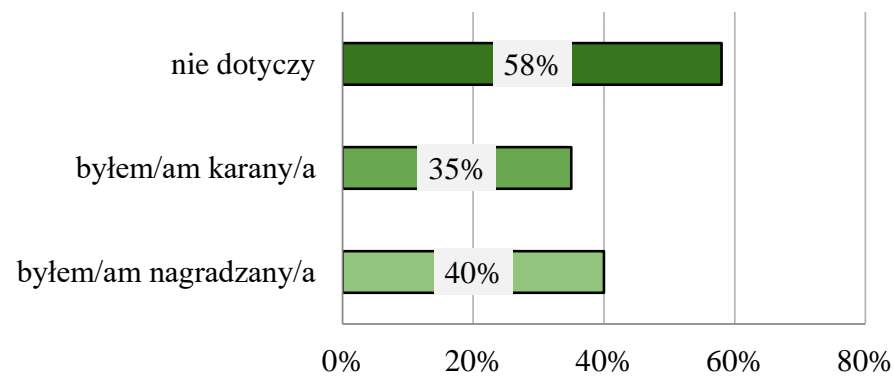

Ryc. 6. Nagradzanie/karanie osób ankietowanych w dzieciństwie

\section{Analiza hipotez badawczych}

Zbadano wcześniej założoną hipotezę pierwszą mówiącą, iż osoby z wykształceniem wyższym będą rzadziej stosowały żywność jako nagrodę lub karę. Wyniki przedstawiono w tabeli 1 . Większość osób z wykształceniem wyższym $(64 \% ; p<0,05)$ zadeklarowała, iż nie stosuje żywności jako formy dyscyplinowania swojego dziecka, co potwierdza słuszność hipotezy pierwszej. 
Tabela 1. Zależność między wykształceniem rodzica, a stosowaniem przez niego żywności jako formy nagrody i/lub kary

\begin{tabular}{|c|c|c|c|c|}
\hline \multirow{2}{*}{ Wykształcenie } & \multirow{2}{*}{$\begin{array}{c}\text { Liczba } \\
\text { ankietowanych }\end{array}$} & \multirow{2}{*}{$\begin{array}{l}\text { Czy stosuje Pan/i } \\
\text { żywność jako na- } \\
\text { grodę i/lub karę? }\end{array}$} & \multicolumn{2}{|c|}{ Odpowiedzi } \\
\hline & & & liczbowe & procentowe \\
\hline \multirow{2}{*}{ Wyższe } & \multirow{2}{*}{189} & tak & 45 & $20 \%^{\mathrm{b}}$ \\
\hline & & nie & 144 & $64 \%^{\mathrm{a}}$ \\
\hline \multirow{2}{*}{ Zawodowe } & \multirow{2}{*}{14} & tak & 5 & $2 \% \mathrm{~cd}$ \\
\hline & & nie & 9 & $4 \%^{\mathrm{c}}$ \\
\hline \multirow{2}{*}{ Średnie } & \multirow{2}{*}{18} & tak & 8 & $4 \%^{\mathrm{c}}$ \\
\hline & & nie & 10 & $4 \%^{\mathrm{c}}$ \\
\hline \multirow{2}{*}{ Podstawowe } & \multirow{2}{*}{4} & tak & 0 & $0 \%{ }^{\mathrm{d}}$ \\
\hline & & nie & 4 & $2 \%^{\mathrm{cd}}$ \\
\hline
\end{tabular}

a, b, c, d różnice statystycznie istotne, $\mathrm{p}<0,05$ (test Duncana)

Aby zbadać hipotezę drugą, króra zakładała, że osoby dorosłe nagradzane i/lub karane jedzeniem w dzieciństwie wobec swoich dzieci również będą stosowały taką metodę wychowawczą, przeanalizowano otrzymane informacje i przedstawiono je w tabeli 2 . Analiza statystyczna wykazała, że rodzice nagradzani i/lub karani w dzieciństwie jedzeniem w 22\% (p < 0,05) nie stosowali tej samej metody wychowawczej wobec swoich dzieci. Jednakże bardzo podobna ilość $(20 \%, \mathrm{p}<0,05)$ rodziców nagradzanych i/lub karanych przyznało, że stosują żywność w tej formie. Uzyskane wyniki wykazały zatem, że na stosowanie tej formy dyscyplinowania dzieci nie wpływają istotnie $(\mathrm{p}<0,05)$ doświadczenia rodziców z dzieciństwa, co nie potwierdza postawionej hipotezy. Z analizy wynika natomiast, iż zdecydowana większość rodziców $(52 \%, p<0,05)$ nie stosowała żywności jako formy wychowawczej wobec swoich dzieci i również sami w latach dzieciństwa nie byli w ten sposób dyscyplinowani. Nieliczni $(6 \%, \mathrm{p}<0,05)$ zadeklarowali, że stosują żywność jako formę nagradzania i/lub karania dzieci, mimo że wobec nich nie stosowano takiej formy.

Tabela 2. Czy osoby dorosłe w przeszłości jako dziecko nagradzane i/lub karane jedzeniem, wobec swoich dzieci stosują taką metodę wychowawczą?

\begin{tabular}{|c|c|c|c|}
\hline \multirow{2}{*}{$\begin{array}{c}\text { Czy rodzic stosuje } \\
\text { żywność jako } \\
\text { nagrodę i/lub karę? }\end{array}$} & $\begin{array}{c}\text { Czy rodzic był jako } \\
\text { dziecko nagradzany } \\
\text { i/lub karany } \\
\text { jedzeniem? }\end{array}$ & liczbowe & Odpowiedzi \\
\cline { 3 - 4 } tak & tak & 44 & $20 \%^{\mathrm{b}}$ \\
& nie & 14 & $6 \%^{\mathrm{c}}$ \\
\hline \multirow{2}{*}{ nie } & tak & 50 & $22 \%^{\mathrm{b}}$ \\
& nie & 117 & $52 \%^{\mathrm{a}}$ \\
\hline
\end{tabular}

a, b, c różnice statystycznie istotne, $\mathrm{p}<0,05$ (test Duncana) 


\section{Podsumowanie}

Powyższe badanie wykazało, że:

- większość respondentów przyznała, że stosowanie żywności jako formy wychowawczej dziecka jest nieprawidłowe,

- wykształcenie było czynnikiem wpływającym na częstotliwość stosowania żywności jako formy dyscyplinowania dzieci. Osoby z wykształceniem wyższym rzadziej stosowały żywność jako formę nagradzania i/lub karania dzieci,

- większość osób dorosłych nagradzanych i/lub karanych za pomocą żywności w dzieciństwie nie stosowało wobec swoich dzieci tej samej metody wychowawczej,

- konieczne jest, aby skutecznie uświadamiać zarówno rodziców, jak i rodziny dzieci, że wszelkie dodatkowe funkcje, które pełni konsumpcja żywności, w tym związane z używaniem żywności jako nagrody za dobre zachowanie i osiągnięcia oraz kary za brak posłuszeństwa, przyczyniają się do zwiększonej konsumpcji produktów spożywczych, co prowadzi do wielu negatywnych skutków, zarówno dla zdrowia psychicznego, jak i fizycznego dzieci w życiu dorosłym.

\section{Bibliografia}

Bilewicz-Wyrozumska T., Lar K., Dul L., Król K., Mroczek A., Zbrojkiewicz E., Złotkowska R., 2015. Analiza wskaźnika BMI u dzieci w województwie śląskim. Zdrowie Dobrostan 2, 2335.

Fedewa A.L., Davis M.C., 2015. How food as a reward is detrimental to children's health, learning, and behaviour. JOSH 85(9), 648-658. https://doi.org/10.1111/josh.12294

Frączek Z., 2014. Nagrody i kary w wychowaniu rodzinnym. Pedag. Rodz. 4(4), 41-55.

Glibowski P., Misztal A., 2016. Wpływ diety na samopoczucie psychiczne. Brom. Chem. Toksykol. 1, 1-9.

Kluz M., 2011. Znaczenie kary w procesie wychowania i kształtowania osobowości dziecka w rodzinie i szkole. Stud. Gdańskie, 28, 159-171.

Kowolik P., 2011. Wychowawcze znaczenie kar i nagród stosowanych w wychowaniu dzieci przedszkolnych. Nauczyciel Szkoła, 1(49), 97-107.

Kwiatkowska K., Winiarska-Mieczan A., Kwiecień M., Klebaniuk R., Krusiński R., Rusinek-Prystupa E., Sembratowicz I., Kamińska E., Danek-Majewska A., Cholewińska E., 2017. Analiza spożycia kawy wśród nauczycieli szkół podstawowych. Probl. Hig. Epidemiol. 98(3), 285-289.

Puhl R.M., Schwartz M.B., 2003. If you are good you have a cookie: how memories of childhood food rules link to adult eating behaviours. Eat. Behav. 4, 283-293. https://doi.org/10.1016/S1471-0153(03)00024-2

Rasińska R., Głowacka-Rębała A., 2013. Wpływ zachowań rodziny na zachowania żywieniowe dzieci. Pielęgniarstwo Polskie 1(47), 12-17.

Van Der Horst K., Sleddens E.F.C., 2017. Parenting styles, feeding styles and food-related parenting practices in relation to toddlers' eating styles: a cluster-analytic approach. PlosOne. 12(5), e0178149. https://doi.org/10.1371/journal.pone.0178149

Vandeweghe L., Vervoort L., Verbeken S., Moens E., Braet C., 2016. Food approach and food avoidance in young children: relation with reward sensitivity and punishment sensitivity. Front Psychol. 7, 928. https://doi.org/10.3389/fpsyg.2016.00928 
Anna Jańczuk ${ }^{1}$

\section{Przyczyny zaniechania karmienia piersią}

Reasons for breastfeeding termination

Karmienie piersią przynosi wiele korzyści zdrowotnych i ekonomicznych. Wyłączne karmienie piersią oznacza, że dziecko przez pierwszych sześć miesięcy życia (m.ż.) otrzymuje tylko mleko matki. Nie są mu podawane inne płyny [Laksono i in. 2021]. Mleko kobiecie dostarcza dziecku wszystkich niezbędnych składników odżywczych [Laksono i in. 2021, Nguyen i in. 2021]. Wyjątek stanowi jedynie witamina D [Francis i in. 2021]. Mleko matki jest bogate w przeciwciała, które chronią młody organizm przed infekcjami. Dodatkowo u dzieci karmionych piersią występuje mniejsza śmiertelność w początkowym okresie życia, zmniejszone ryzyko alergii, otyłości, ale również większy iloraz inteligencji w wieku późniejszym. Korzyści ze strony matki to m.in. ograniczenie występowania depresji poporodowej, otyłości, ryzyka zachorowania na raka jajnika, piersi czy cukrzycy typu II [Laksono i in. 2021, Nguyen i in. 2021]. Światowa Organizacja Zdrowia (WHO) zaleca, aby dziecko było karmione wyłącznie piersią do 6. m.ż., po tym czasie należy wprowadzać pokarmy uzupełniające i kontynuować karmienie piersią.

Karmienie naturalne rozpoczyna zwykle ponad $90 \%$ matek, niestety z wielu powodów stopniowo rezygnują z tego sposobu żywienia. Kluczem do rozwiązania tego problemu jest dostęp do wykwalifikowanej pomocy, która pomoże młodym kobietom w rozwijaniu prawidłowych praktyk karmienia oraz udzieli niezbędnych porad, gdy pojawią się problemy laktacyjne [Francis i in. 2021]. Do najczęstszych przyczyn rezygnacji przez matki z karmienia piersią zalicza się zbyt niski przyrost masy ciała niemowląt, chorobę matki, konieczność zażywania lekarstw, wysiłek związany z koniecznością odciągania mleka, niewystarczająca podaż mleka, ból sutków i piersi [Odom i in. 2013, Morrison i in. 2019]. Najlepsze efekty w radzeniu sobie z problemami laktacyjnymi przynosi połączenie porady kompetentnych osób (doradców laktacyjnych) i udziału w grupie wsparcia matek karmiących [Rodríguez-Gallego i in. 2021]. Szybciej z karmienia piersią rezygnują matki, których dzieci były niechcianą ciążą, urodziły się przez cesarskie cięcie oraz te, które rzadziej otrzymywały wsparcie społeczne. Wsparcie ze strony partnera czy rodziny jest istotnym elementem, który wydłuża okres karmienia piersią [Faghani 2019]. Bardzo ważne jest również, żeby dziecko po porodzie możliwie szybko zostało przystawione do piersi. Uważa się, powinnno to być nie później niż po godzinie. Praktyka ta zwiększa powodzenie prawidłowego rozpoczęcia karmienia piersią [Cadwell 2007, DiGirolamo i in. 2008].

\footnotetext{
${ }^{1}$ Uniwersytet Przyrodniczy w Lublinie, Instytut Oceny Jakości i Przetwórstwa Produktów Zwierzęcych, annajanczuk44@gmail.com
} 
Celem pracy było przeprowadzenie badania ankietowego ukierunkowanego na poznanie aktualnego stanu wiedzy o korzyściach wynikających z karmienia naturalnego oraz przyczyn wcześniejszego zaprzestania karmienia piersią.

\section{Materiały i metody}

Badanie ankietowe przeprowadzone zostało w grupie 132 kobiet w wieku do 35 lat, które posiadały dziecko do 2. roku życia (r.ż.). Udział w badaniu był dobrowolny oraz anonimowy. Do jego przeprowadzenia wykorzystano platformę internetową, a respondentki pozyskane zostały przy wykorzystaniu portalu społecznościowego. Kwestionariusz ankiety składał się z 17 pytań zamkniętych. Arkusz zawierał metryczkę, a także pytania dotyczące sposobu karmienia niemowląt, okresu karmienia piersią, jak też powodów rezygnacji z karmienia naturalnego.

\section{Wyniki}

Ankieta została wypełniona przez 132 respondentki, z których 64\% miało 25-35 lat, a 24\% - 18-24 lata. Najwięcej ankietowanych kobiet zamieszkiwało wieś (31\%), następnie miasta: od 50 do 200 tys. mieszkańców (29\%), do 50 tys. mieszkańców (23\%), powyżej 200 tys. mieszkańców (17\%). Dominująca część respondentek miała wykształcenie wyższe (61\%), mniejsza część wykształcenie średnie (30\%). Na dalszym miejscu plasowały się kobiety o wykształceniu zawodowym oraz podstawowym. Większość matek, bo aż $62 \%$, urodziło dziecko siłami natury, a pozostałe $38 \%$ przez cesarskie cięcie. Powyżej 3500 g ważyło 49\% noworodków, natomiast $48 \%$ między 2500 a 3500 g. Tylko $3 \%$ dzieci ważyło mniej niż $2500 \mathrm{~g}$. W momencie badania ankietowego $36 \%$ dzieci miało od 19 do 24 miesięcy, kolejne 33\% to dzieci między 13. a 18. m.ż, 14\% miało 7-12 miesięcy, $11 \%$ od 4 do 6 miesięcy, a najmniej liczną grupę stanowiły dzieci w przedziale od 1 do 3 m.ż. (7\%). Prawie wszystkie respondentki (97\%) rozpoczęły karmienie piersią po porodzie. Tylko $3 \%$ zapytanych kobiet nie rozpoczęło karmienia naturalnego.

Na rycinie 1 przedstawiono odpowiedzi na pytanie, do jakiego wieku dziecko było karmione piersią. Największa liczba kobiet (24\%) karmiła dziecko piersią do 2.-3. miesiąca po porodzie. Drugie miejsce zajęły respondentki, które karmiły piersią powyżej 1. r.ż. dziecka. Na trzecim miejscu uplasowały się ankietowane, które tylko przez pierwszy miesiąc karmiły naturalnie.

Kolejne pytanie dotyczyło dodatkowego stosowania mieszanek mlekozastępczych podczas karmienia piersią. Okazuje się, że aż 58\% respondentek postępowało w prawidłowy sposób podczas karmienia i nie podawało dzieciom tego typu produktów. Pozostałe $42 \%$ matek dokarmiało dzieci mieszankami mlekozastępczymi.

Zestawienie odpowiedzi na najważniejsze pytanie - o powód rezygnacji z karmienia piersią - przedstawiono na rycinie 2 . Najczęstszą przyczyną wskazywaną przez kobiety była niechęć dziecka do ssania piersi (19\%). Kolejne 17\% respondentek wskazało zbyt małą ilość pokarmu. Po 14\% respondentek zaznaczyło powrót do pracy, szkoły oraz inny powód niesprecyzowany $\mathrm{w}$ ankiecie. 


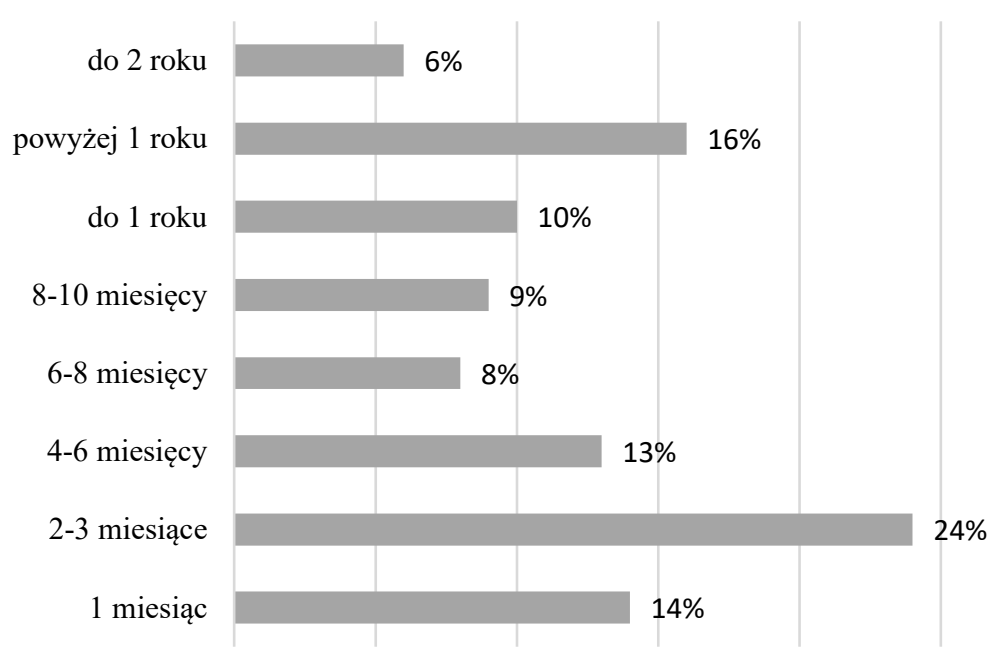

Ryc. 1. Okres karmienia dziecka piersią

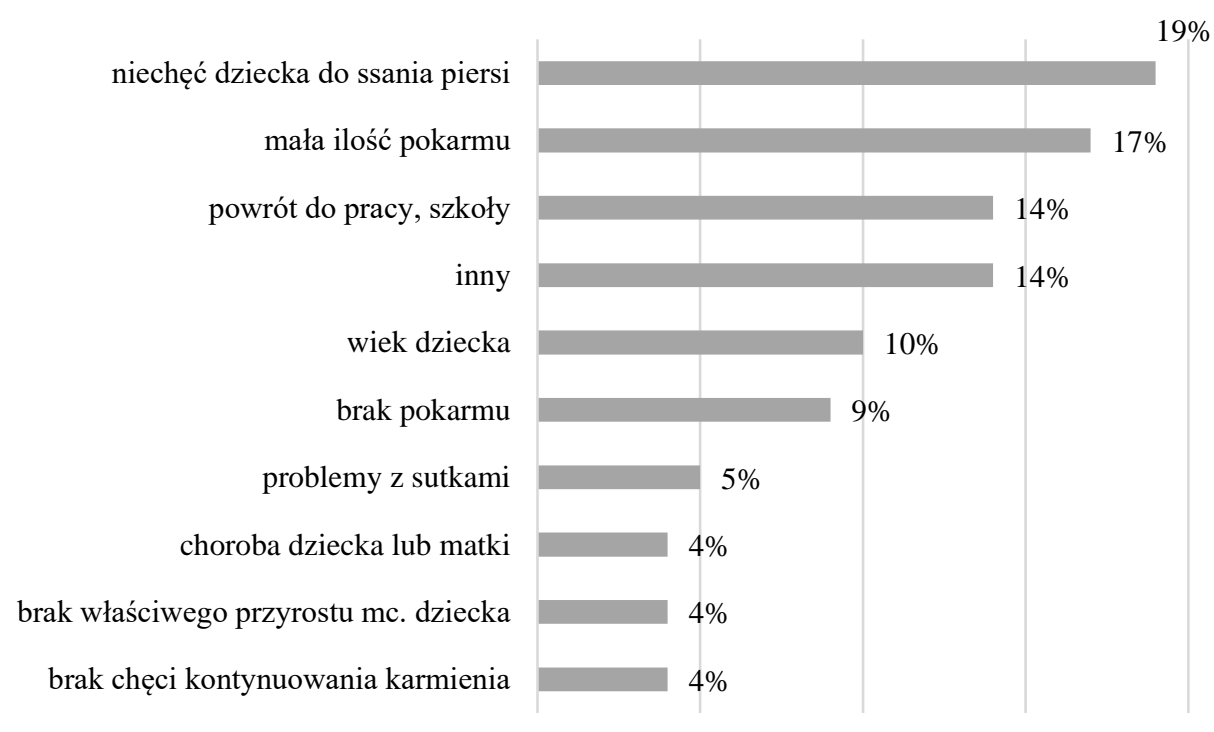

Ryc. 2. Powody rezygnacji z karmienia piersią

Kolejne pytanie dotyczyło oceny stanu wiedzy respondentek o korzyściach pojawiających się w wieku późniejszym u dzieci, które były karmione piersią. Dominująca część kobiet (61\%) uważała, że karmienie piersią zmniejsza ryzyko występowania infek- 
cji, 45\% twierdziło, iż karmienie ma związek ze zmniejszaniem ryzyka alergii. Prawidłowej odpowiedzi, że naturalne karmienie wiąże się ze wszystkimi korzyściami zdrowotnymi wymienionymi w pytaniu, udzieliło $43 \%$ respondentek.

W badaniu ankietowym poruszono również temat konieczności podawania niemowlętom karmionym piersią do 6. m.ż. innych płynów, takich jak woda, soki czy mieszanki mlekozastępcze. Prawidłowej odpowiedzi na powyższe pytanie udzieliło $73 \%$ respondentek, a $21 \%$ błędnie twierdziło, że niemowlętom należy dodatkowo podawać inne płyny. Pozostałe 5\% nie znało odpowiedzi na pytanie. W kolejnym pytaniu respondentki zostały poproszone o wyrażenie opinii na temat wzbogacania, dodatkowego dokarmiania mieszankami mlekozastępczymi wcześniaków z masą urodzeniową powyżej $1500 \mathrm{~g}$. Większość respondentek (42\%) nie znała odpowiedzi na to pytanie, odpowiedź negatywną wskazało $41 \%$, a pozytywną tylko $17 \% \mathrm{z}$ nich.

Problemy laktacyjne występowłay u 50\% badanych kobiet. Ankietowanym zadano również pytanie o skorzystanie z porady laktacyjnej. Położną o poradę poprosiło $31 \%$ matek, niestety również $31 \%$ nie skorzystało z takiej możliwości. Ważne jest, że aż $66 \%$ kobiet, które zwróciły się po poradę, było z niej zadowolonych. Pozostałe $34 \%$ nie było usatysfakcjonowanych z uzyskanych wskazówek.

Na końcu zapytano matki o korzyści zdrowotne wynikające z karmienia piersią dla nich samych. Zdecydowana większość (58\%) ankietowanych uważała, iż karmienie naturalne pozwala na szybszy powrót do masy ciała sprzed ciąży, ponadto zmniejsza ryzyko zachorowania na raka sutka i jajnika (41\%). W dalszej kolejności wskazywano, że karmienie piersią wiąże się ze wszystkimi wymienionymi w tym pytaniu aspektami zdrowotnymi.

\section{Dyskusja}

Niniejsze badania dowodzą, że karmienie piersią jest najczęściej wybieranym sposobem karmienia dzieci. Otrzymane dane są porównywalne z wynikami uzyskanymi przez Ćwiek i in. [2010], według których 92\% kobiet rozpoczęło karmienie piersią. Stańczyk-Przyłuska i in. [2010] poruszyli tematykę rozpoczęcia karmienia piersią oraz okresu karmienia w rodzinach obciążonych i nieobciążonych częstszym występowaniem chorób alergicznych. Początkowo karmienie naturalne rozpoczęło 90\% kobiet, lecz ta liczba w miarę upływu czasu zmniejszała się znacząco. Zauważono, że matki z grupy nieobciążonej dłużej karmiły piersią.

$\mathrm{Z}$ przeprowadzonej ankiety wynika, iż najwięcej kobiet karmiło dzieci piersią przez pierwsze 2-3 m.ż. Zalecenia WHO i ESPGHAN (Europejskiego Towarzystwa Gastroenterologii Dziecięcej, Hepatologii i Żywienia) dotyczące długości okresu karmienia piersią, wskazują na naturalne karmienie dzieci przez min. pierwsze 6 m.ż. [Agostini i in. 2008]. Wyniki własne wskazują jednak, że tylko $13 \%$ matek karmiło dzieci piersią do 4-6 m.ż., a przez 6-8 miesięcy karmiło już tylko 8\% kobiet. Są to wyniki podobne do okresu karmienia piersią przez matki w innych krajach. Kohortowe wyniki badań pokazują, że 8\% dzieci pochodzących z Ameryki, 2\% dzieci z Norwegii i 0,2\% dzieci z Irlandii było nadal karmionych piersią w 6 . m.ż. [Hetzner i in. 2009, Häggkvist $i$ in. 2010, Tarrant i in. 2010]. Badania Ćwiek i in. [2010] przedstawiają o wiele bardziej zadowalające dane. 
Wynika z nich, że aż 31,5\% kobiet karmiło dzieci piersią do 6. m.ż. Podobne wyniki otrzymali Filder-Witoń i in. [2010], według których w 6. m.ż. 33,5\% niemowląt była karmiona naturalnie. Odniesienie długości karmienia piersią do 6. m.ż. jest jednak niemożliwe, gdyż w ankiecie nie pojawiła się taka odpowiedź, a jedynie zakresy, tj. 4-6 oraz 6-8 miesięcy. Nie wiadomo, ile dokładnie matek karmiło naturalnie przez 6 miesięcy po porodzie. Odnotowany w badaniach własnych odsetek kobiet karmiących piersią powyżej 1. roku był wysoki. Natomiast w badaniach Ćwiek i in. [2010] było to tylko 2\% kobiet.

Głównym celem pracy nie była jednak ocena długości karmienia piersią, lecz przyczyn jego zaprzestania. Jako pierwszorzędny powód do podjęcia tej decyzji respondentki wskazywały niechęć dziecka do ssania piersi, ponadto małą ilość pokarmu oraz powrót do pracy czy szkoły. W badaniach Ćwiek i in. [2010] głównym powodem zaprzestania karmienia piersią przez kobiety był powrót do pracy (43\%), następnie zbyt mała ilość pokarmu (29\%) oraz niechęć dziecka do ssania piersi (19\%). Przyczyną zaprzestania karmienia piersią przez matki mogą być problemy z laktacją. Z badań Jasik i in. [2014] wynika, że najczęstszym problemem laktacyjnym był niewłaściwy sposób przystawiania dziecka do piersi oraz nieprawidłowa technika karmienia (90\%), a także pojawiający się nawał pokarmu (98\%). Ogromnym problemem dla kobiet bardzo często staje się również pozorny niedobór pokarmu (75\%). Można jednak spróbować sobie z tym wszystkim poradzić. W tym celu należy skorzystać z pomocy wykwalifikowanych doradców laktacyjnych i położnych. Z badań przeprowadzonych przez Jasik i in. [2014] wynika, że problemy z laktacją wystąpiły aż u 50\% matek. Co ciekawe, 31\% kobiet nie poprosiło nikogo o pomoc, ale równie liczna grupa skorzystała z pomocy położnej. Aż $66 \%$ osób, które skorzystały z porady, było z niej zadowolonych. Można wnioskować, że wiele kobiet, które nie zwróciły się do nikogo o pomoc, po uzyskaniu porady mogłoby kontynuować karmienie piersią. W badaniach Ćwiek i in. [2010] do problemów z laktacją przyznało się $67 \%$ kobiet. Ankietowane skorzystały głównie z porady położnej (37\%) oraz lekarza pediatry (32\%). Odsetek kobiet zadowolonych z porady wynosił $74 \%$.

$\mathrm{W}$ badaniu ankietowym zadano pytanie o korzyści wynikające z karmienia piersią dla matek oraz dla ich dzieci. 43\% kobiet potrafiło prawidłowo wskazać korzyści zdrowotne dla dzieci. Za najistotniejsze korzyści dla kobiet uznano z kolei szybszy powrót do masy ciała sprzed ciąży oraz zmniejszenie ryzyka zachorowania na raka sutka i jajnika. Ankietowane nie znały innych korzystnych aspektów zdrowotnych.

\section{Podsumowanie}

Kluczowe jest promowanie karmienia piersią oraz przekonywanie, aby trwało jak najdłużej. Najwięcej badanych kobiet karmiło piersią dzieci tylko do 2.-3. m.ż., a to zdecydowanie zbyt krótko i wbrew przyjętym zaleceniom. Kobiety planujące ciążę, ciężarne, ale także matki potrzebują dodatkowej edukacji w zakresie karmienia piersią. Warto, aby wiedziały, że problemy laktacyjne nie muszą oznaczać zaprzestania karmienia piersią, lecz wskazują na konieczność zwrócenia się do odpowiedniej osoby po pomoc. Ważna jest również dodatkowa promocja korzyści zdrowotnych płynących z naturalnego karmienia zarówno dla dziecka, jak i matki. 


\section{Bibliografia}

Agostoni C., Decsi T., Fewtrell M. I., 2008. ESPGHAN Committee on Nutrition, Complementary feeding: a commentary by the ESPGHAN Committee on Nutrition. J. Pediatr. Gastroenterol. Nutr. 46, 99-110. https://doi.org/10.1097/01.mpg.0000304464.60788.bd

Cadwell K., 2007. Latching-on and suckling of the healthy term neonate: breastfeeding assessment. JMWH 52(6), 638-642. https://doi.org/10.1016/j.jmwh.2007.08.004

Ćwiek D., Branecka-Woźniak D., Fryc D., Grochans E., Malinowski W., 2010. Przyczyny zaniechania karmienia piersią oraz możliwości wsparcia podczas problemów z laktacją w północnozachodniej części polski. Rocz. Pomor. Akad. Med. Szczec. 56(2), 129-132.

DiGirolamo A.M., Grummer-Strawn L.M., Fein S.B., 2008. Effect of Maternity-Care Practices on Breastfeeding. J. Pediatr. 122(2), 43-49. https://doi.org/10.1542/peds.2008-1315e

Faghani A.M., Karimi K.M., Fayazi S., Tork Z.S., Amerian M., 2019. On the relationship between social support and early breastfeeding termination. PCNM 9(1), 1-11. https://doi.org/10.29252/pcnm.9.1.1

Fidler-Witoń E., Mikołajczak K., Waberska M., Miśkiewicz-Chotnicka A., Walkowiak J., 2010. Żywienie niemowląt a aktualne rekomendacje. Nowiny Lek. 79(5), 356-361.

Francis J., Mildon A., Stewart S., Underhill B., Ismail S., Ruggiero E.D., Tarasuk V., Daniel W., O'Connor S.D., 2021. Breastfeeding rates are high in a prenatal community support program targeting vulnerable women and offering enhanced postnatal lactation support: a prospective cohort study. J. Equity Health 20(71).

Häggkvist A.P., Brantsćter A.L., Grjibovski A.M., 2010. Prevalence of breast-feeding in the Norwegian mother and child cohort study and health service-related correlates of cessation of full breast-feeding. Public Health Nutr. 25, 1-11.

Hetzner N.M., Razza R.A., Malone L.M., 2009. Associations among feeding behaviors during infancy and child illness at two years. Child Health J. 13, 795-805.

Jasik J. 2014. Karmienie naturalne - cenny dar i kamień milowy opieki nad noworodkiem. Rocz. Lub. 40(2), 247-259.

Laksono A.D., Wulandari R.D., Ibad M., Kusrini I., 2021. The effects of mother's education on achieving exclusive breastfeeding in Indonesia. BMC Public Health 21(14), 516. https://doi.org/10.1186/s12889-020-10018-7

Morrison A.H., Gentry R., Anderson J., 2019. Mothers' reasons for early breastfeeding. MCN 44(6), 325-330. https://doi.org/10.1097/NMC.0000000000000566

Nguyen, N.T., Prasopkittikun, T., Payakkaraung, S., Vongsirimas, N., 2021. Factors predicting sixmonth exclusive breastfeeding among mothers in Ho Chi Minh City, Vietnam. J. Health Res. https://doi.org/10.1108/JHR-03-2020-0080

Odom E.C., Li R., Scanlon K.S., Grummer-Strawn C.G., 2013. Reasons for earlier than desired cessation of breastfeeding. Pediatrics 131(3), 726-732. https://doi.org/10.1542/peds.2012-1295

Rodríguez-Gallego I., Leon-Larios F., Corrales-Gutierrez I., González-Sanz J.D., 2021. Impact and effectiveness of group strategies for supporting breastfeeding after birth: a systematic review. Int. J. Environ. Res. Public Health 18(5), 2550. https://doi.org/10.3390/ijerph18052550

Stańczyk-Przyłuska A., Giurowa D., Stańczyk M., Arendarczyk J., Kowalski M.L., Zeman K., Wilczyński J., 2010. Karmienie piersią w rodzinach obciążonych i nieobciążonych chorobami alergicznymi. Alerg. Astma Immunol. 15(4), 208-213.

Tarrant R.C, Younger K.M, Sheridan-Pereira M., 2010. Factors associated with weaning practices in term infants; a prospective observational study in Ireland. BJN 5, 1-11. https://doi.org/10.1017/S0007114510002412 
Paulina Jedut $^{1}$, Iwona Niedźwiedź ${ }^{1}$, Paweł Glibowski ${ }^{1}$

\section{Najczęstsze niedobory żywieniowe $\mathrm{w}$ diecie wegetarian i sposoby im zapobiegania}

The most common nutritional deficiencies in the diet of vegetarians and ways to prevent them

Popularność stosowania diety wegetariańskiej rośnie. Zwiększający się odsetek wegetarian jest m.in. wynikiem publikowania coraz nowszych doniesień o pozytywnym oddziaływaniu diety roślinnej na zdrowie. Wiele badań kohortowych potwierdza, że dieta niskotłuszczowa, bogata w owoce, warzywa i błonnik może zmniejszać ryzyko chorób układu krążenia, poprawy profilu lipidowego [Wang i in. 2015], obniżenia masy ciała [Rosell i in. 2006] oraz ciśnienia tętniczego [Berkow i Barnard 2005]. Ponadto istnieją badania wskazujące, że stosowanie diety wegetariańskiej zmniejsza ryzyko zachorowania na nowotwory oraz cukrzycę typu 2 [Jenkins i in. 2003, Khan i in. 2008]. Niemniej jednak dieta wegetariańska budzi wiele kontrowersji. Związane jest to z rezygnacją ze spożywania mięsa, a często i innych produktów pochodzenia zwierzęcego, które znajdują się w diecie człowieka od zarania dziejów. W zależności od rodzaju diety wegetariańskiej jest ona mniej lub bardziej restrykcyjna. Dane sugerują, że wegetarianie, a w szczególności weganie, całkowicie wykluczający ze swojej diety produkty pochodzenia zwierzęcego, są narażeni m.in. na niedobory składników odżywczych, mineralnych oraz witamin, zwiększone ryzyko wzrostu stężenia homocysteiny we krwi, czynnika postępowania chorób układu krążenia [Chang-Claude i in. 2005, Philips 2005] oraz na niewystarczającą mineralizację kości prowadzącą do rozwoju osteoporozy [Ho-Pham i in. 2009].

W niniejszej pracy zostaną przedstawione najczęściej kojarzone niedobory żywieniowe, które mogą pojawić się w diecie wegetarian oraz sposoby im zapobiegania.

\section{Niedobór białka}

Diety wegetariańskie z udziałem produktów pochodzenia zwierzęcego: jaj, produktów mlecznych, jak również ryb, pozwalają na dostarczenie wszystkich składników odżywczych, głównie pełnowartościowego białka [Nazarewicz 2007]. Pewne jest, że całkowita ilość białek dostarczona $\mathrm{z}$ diety wegetarian jest mniejsza w porównaniu $\mathrm{z}$ dietą tradycyjną [Berkow i Barnard 2006]. Przeprowadzono doświadczenie oceniające wpływ stosowania diety wegetariańskiej na wybrane parametry morfologiczne i biochemiczne krwi. W badaniu wzięło udział 41 osób, w tym 22 wegetarian i 19 niewegetarian. Badani nie chorowali, a ich BMI było w normie. Uzyskane wyniki w obu grupach znajdowały się na poziomie wartości referencyjnych. Wykazano różnice istotnie statystyczne

\footnotetext{
${ }^{1}$ Uniwersytet Przyrodniczy w Lublinie, Wydział Nauk o Żywności i Biotechnologii, Katedra Biotechnologii, Mikrobiologii i Żywienia Człowieka, paulinajedut1@wp.pl
} 
W zawartości procentowej neurocytów oraz limfocytów. Bowiem zawartość procentowa neurocytów i limfocytów była mniejsza u wegetarian. Na szczególną uwagę zasługuje znacznie mniejsze stężenie mocznika w osoczu wegetarian, co w połączeniu z obniżonym stężeniem limfocytów wskazuje na niedobory pełnowartościowego białka w diecie wegetarian [Nazarewicz 2007].

Białka są głównym składnikiem budulcowym mięśni i innych komórek ciała. Odpowiednia podaż białek z dietą zapewnia prawidłowy rozwój, działanie mięśni, transmisję impulsu nerwowego oraz odporność immunologiczną [Joint WHO/FAO/UNU Expert Consultation 2017]. Żywność bogatą w pełnowartościowe białko stanowią głównie produkty pochodzenia zwierzęcego oraz niektóre pochodzenia roślinnego, tj. soja, quinoa oraz amarantus. W porównaniu z produktami zwierzęcymi zawierają znacznie mniejsze stężenia aminokwasów: leucyny, metioniny, lizyny i tryptofanu [Marsh i in. 2013].

Pomimo tego iż dieta wegetariańska dostarcza małe ilości pełnowartościowego białka, uważa się, że większe spożycie białka pochodzenia roślinnego może być jednym z powodów, dla którego wegetarianie są mniej narażeni na występowanie nadwagi, otyłości oraz chronicznych schorzeń [Marsh i in. 2013].

Aby nie dopuścić do wystąpienia niedoborów białka, dieta wegetariańska powinna być odpowiednio zbilansowana. Według dokumentu „Normy żywienia dla populacji polskiej i ich zastosowanie" [2020] za odpowiednią ilość białka dla osób dorosłych uznaje się od 10\% do 20\% dziennego zapotrzebowania energetycznego [Jarosz i in. 2020]. Najlepszym źródłem białka w diecie wegetarian są: jaja i produkty mleczne. W przypadku bardzo restrykcyjnych diet wegetariańskich, np. w diecie wegańskiej bardzo dobrym źródłem białka są rośliny strączkowe (soja, ciecierzyca, soczewica, fasola, groch łuskany, fasola), produkty pełnoziarniste (ryż brązowy, kasza gryczana, quinoa, amarantus), produkty sojowe (jogurt, mleko, tofu, tempeh) oraz orzechy i nasiona [Nazarewicz 2007, Pyrzyńska 2013]

Nawet dieta wegetariańska całkowicie wykluczająca produkty pochodzenia zwierzęcego może dostarczyć odpowiednią ilość białka, jednak jest to możliwe tylko, jeżeli będzie ona urozmaicona i odpowiednio zbilansowana.

\section{Niedobór witaminy $B_{12}$}

W wyniku długotrwałego stosowania diety wegetariańskiej, a w szczególności wegańskiej, często dochodzi do niedoboru witaminy $B_{12}$ [Chabasińska i in. 2008]. Witamina $\mathrm{B}_{12}$, inaczej nazywana kobalaminą jest niezbędna dla ludzkiego organizmu. Bierze udział w syntezie DNA i utrzymaniu integralności mieliny nerwowej [Zeuschner i in. 2012]. W przeciwieństwie do laktoowowegetarian i osób stosujących dietę tradycyjną, weganie odznaczają się niskim stężeniem witaminy $\mathrm{B}_{12}$ oraz wyższym stężeniem homocysteiny. Niedobór może skutkować chorobami neurologicznymi, m.in. ataksją, psychozą, demencją, zaburzeniami nastroju i motoryki, problemami z koncentracją itd. Ponadto dzieci mogą doświadczyć apatii i nieprawidłowości w rozwoju, a także anemii makrocytowej, która jest powszechnym skutkiem, niezależnie od wieku [Craig 2009]. Wegetarianie charakteryzują się wyższym stężeniem folianów, dostarczanych wraz z dietą bogatą $\mathrm{m}$.in. $\mathrm{w}$ warzywa liściaste, w porównaniu ze stężeniem witaminy $\mathrm{B}_{12}$. Taka różnica stężeń powoduje maskowanie niedoboru kobalaminy przez nadmiar folianów [Zeuschner i in. 2012]. 
Problem niedoboru witaminy B12 wśród osób stosujących dietę roślinną jest dość powszechny. W badaniach Gilising i in. [2010] wykazano, że 121 z 239 wegan odznaczało się niedoborem witaminy $\mathrm{B}_{12}$, przy czym wśród 231 wegetarian było to 16 osób. Dla porównania jedynie 1 osoba spośród 226 będących na diecie tradycyjnej charakteryzowała się niedoborem tej witaminy. Co więcej uważa się, że częstość występowania niedoboru zwiększa się wraz z dłuższym czasem stosowania diety wegetariańskiej, ponieważ może minąć kilka lat, zanim w organizmie pojawią się niedobory tej witaminy. Jest wielce prawdopodobne, że u wszystkich wegan, którzy nie spożywają produktów pochodzenia zwierzęcego (największa zawartość) oraz nie suplementują witaminy $\mathrm{B}_{12}$, ostatecznie rozwinie się niedobór [Zeuschner i in. 2012]. Zespół Chabasińskiej [2008] przeprowadził badanie, którego celem była ocena stężenia witaminy $\mathrm{B}_{12} \mathrm{~W}$ surowicy $\mathrm{i}$ sprawdzenie wpływu rodzaju diety i długości jej stosowania. W badaniu wzięło udział 118 wegetarian, z czego 40 osób stanowili weganie, oraz 90 osób stosujących dietę tradycyjną. Grupę wegetarian podzielono ze względu na długość stosowania diety: krócej niż 5 lat i dłużej niż 5 lat. Badanie jednoznacznie wykazało, że rodzaj stosowanej diety wegetariańskiej istotnie wpłynął na stężenie witaminy $\mathrm{B}_{12}$. Przyznano, że dieta wegańska najbardziej sprzyja awitaminozie kobalaminy. Zasugerowano również, że stężenie witaminy $\mathrm{B}_{12} \mathrm{~W}$ surowicy badanych było także uzależnione od długości stosowania diety. Zmagazynowane $\mathrm{w}$ organizmie zasoby witaminy $\mathrm{B}_{12}$ wystarczają na ok. 5-6 lat. Porównując stężenia kobalaminy u osób na diecie wegetariańskiej, stosujących ją krócej niż 5 lat do osób na diecie tradycyjnej, nie zaobserwowano istotnych różnic. Inaczej było w przypadku stosowania diety wegetariańskiej ponad 5 lat - w tym przypadku wykazano znaczny deficyt witaminy $B_{12}$ [Chabasińska i in. 2008].

Dieta laktoowowegetarian zawiera niezawodne źródło witaminy $\mathrm{B}_{12}$, jakim są produkty mleczne oraz jaja [Renada i Fischer 2010]. Jednakże osoby stosujące dietę wegańską nie mają wielu możliwości dostarczenia z żywnością odpowiedniej porcji witaminy $\mathrm{B}_{12}$ [Zeuschner i in. 2012]. Jednym z coraz bardziej popularnych wśród wegan roślinnych źródeł witaminy $\mathrm{B}_{12}$ są algi jadalne. Głównie Enteromorpha sp. i Porphyra sp. zawierają znaczne ilości witaminy $B_{12}$ (odpowiednio ok. 63,6 $\mu \mathrm{g} / 100 \mathrm{~g}$ suchej masy i 32,3 $\mu \mathrm{g} / 100$ g suchej masy) [Wantanabe i in. 1999]. Zespół Nakos [2017] analizował zawartość witaminy $\mathrm{B}_{12} \mathrm{w}$ owocach rokitnika zwyczajnego. Okazuje się, że w 100 g suchej masy zawiera się 37,01 $\mu \mathrm{g}$ witaminy $\mathrm{B}_{12}$. Może to oznaczać, że rokitnik jest rośliną o największej zawartości tej witaminy.

Żywność wzbogacana w witaminę $\mathrm{B}_{12}$ jest niezwykle popularna w USA. Są to: mleko sojowe, drożdże oraz analogi mięsa wytwarzane z soi [Zeuschner i in. 2012]. Zbadano, czy taka żywność znajduje się na polskim rynku, oraz oceniono możliwość zastosowania takich produktów w codziennej diecie wegan, aby podwyższyć stężenie witaminy $\mathrm{B}_{12}$. Analizę przeprowadzono w 11 dużych sieciach handlowych w Warszawie. Produkty były wzbogacone dwiema formami chemicznymi witaminy $\mathrm{B}_{12}$ - cyjanokobalaminą i hydroksykobalaminą. Zidentyfikowano 220 produktów. Największą grupę stanowiły płatki śniadaniowe i kolejno soki, nektary oraz napoje bezalkoholowe, słodycze, napoje i desery sojowe, margaryny oraz jogurty owocowe. Przeanalizowano możliwości zwiększonego dostarczenia witaminy $\mathrm{B}_{12}$ do organizmu przez codzienne spożywanie produktów fortyfikowanych i stwierdzono, że jednorazowe spożycie przeciętnej porcji pokrywa od 7,5 do 20,8\% dziennego zapotrzebowania osoby dorosłej. Kontrowersyjne jest 
zalecenie spożywania produktów takich jak: cukierki, słodkie napoje owocowe. Najlepszym rozwiązaniem byłoby wzbogacenie produktów, które można zalecić do spożywania każdemu w urozmaiconej i zbilansowanej diecie [Sicińska i in. 2012].

\section{Niedobór witaminy D i wapnia}

Najważniejszym źródłem witaminy D jest organizm człowieka. Niezbędne do jej wyprodukowania jest światło słoneczne. Prowitamina D, nazywana 7-dehydrocholesterolem znajduje się w warstwie naskórka. Pod wpływem działania UVB (promieniowania ultrafioletowego), w wyniku szeregu przemian przekształcana jest w tzw. kalcydiol. Problem niedoboru witaminy D jest istotny przez kolejne dwie pory roku (jesień i zimę), gdy promieni słonecznych jest niewiele.

Dodatkowo zagrożenie jest tym większe, im bardziej restrykcyjną dietę wegetariańską się stosuje. Witaminę $\mathrm{D}_{3}$ (cholekalcyferol) można również dostarczać z pożywieniem. Jej naturalnym źródłem są produkty pochodzenia zwierzęcego (tran, tłuste ryby, produkty mleczne, jaja, mięso). W zależności od rodzaju stosowanej diety ratunkiem dla wegetarian może być fortyfikowana żywność: płatki śniadaniowe, ekstrakt z drożdży, produkty sojowe, margaryny, produkty do smarowania pieczywa [Philips 2005]. Sprawa wygląda inaczej w przypadku wegan. Większość z nich nie spożywa żywności fortyfikowanej, ponieważ jest wzbogacana cholekalcyferolem pochodzenia zwierzęcego. Przez to narażeni są na awitaminozę witaminy $\mathrm{D}_{3}$ [Ambroszkiewicz i in. 2010]. W zastępstwie przyjmują ergokalcyferol (witaminę $\mathrm{D}_{2}$ ), który jest gorzej wchłanianiy niż witamina $\mathrm{D}_{3}$ [Craig 2009].

Większość wegetarian jest świadomych problemów, jakie niesie za sobą niedostateczna podaż witaminy $\mathrm{D}$, dlatego wspomagają się suplementami diety. Stężenie 25 - hydroksycholekalcyferolu w surowicy plasować się powinno na poziomie $30-50 \mathrm{ng} / \mathrm{ml}$. Aby ograniczyć ryzyko niedoboru do minimum, warto na bieżąco kontrolować jego stężenie, wykonując badania biochemiczne krwi. Dla osób dorosłych oraz seniorów, zalecana jest dawka suplementacyjna na poziomie 800-2000 IU w okresie jesienno-zimowym lub przez cały rok [Zdrojewicz i in. 2015]. Na polskim rynku można znaleźć wiele preparatów z różnymi formami witaminy $\mathrm{D}$, która kryje się pod różnymi nazwami: cholekalcyferol, ergokalcyferol oraz kalcyfediol. Preparaty należy pobierać w trakcie spożywania posiłków, dzięki czemu lepiej się wchłoną [Zdrojewicz i in. 2015]

Z niedoborem witaminy $\mathrm{D}$ wiąże się niedobór wapnia. Witamina $\mathrm{D}$ zwiększa wchłanianie, jednocześnie zmniejszając wydalanie wapnia [Bolanowski i Bolanowski 2005]. W diecie laktoowowegetarian niedobór tego składnika nie stanowi dla problemu, ponieważ dzienne zapotrzebowanie pokrywają dzięki produktom mlecznym [Craig 2009]. Stężenie wapnia wśród wegan, którzy całkowicie odrzucają spożywanie produktów mlecznych, jest znacznie mniejsze, co skutkuje jego niedoborem [Philips 2005]

Wapń jest niezwykle ważnym składnikiem mineralnym. Wpływa na kurczliwość mięśni, przewodnictwo nerwowe, krzepnięcie krwi, prawidłową mineralizację kości i wiele innych. Źródłem wapnia w diecie wegan są: nasiona roślin strączkowych, warzywa liściaste, nasiona sezamu, orzechy, glony [Pyrzyńska 2013]. Wspomagać się można również fortyfikowaną żywnością - mlekiem sojowym, sokami owocowymi, mlekiem ryżowym, płatkami śniadaniowymi [Craig 2009]. Dzienne zapotrzebowanie na wapń wynosi 800-1200 mg, a wchłanianie u osoby dorosłej plasuje się na poziomie jedynie 30-40\%. 
Jeżeli podaż wapnia z dietą jest niewystarczająca, warto wspomóc się suplementacją, aby nie dopuścić do niedoboru, który może być bardzo niebezpieczny dla organizmu [Dolińska $i$ in. 2009].

\section{Niedobór żelaza}

Żelazo jest niezbędnym składnikiem mineralnym do tworzenia hemoglobiny i mioglobiny. Jest istotne dla zdrowia i prawidłowego samopoczucia. W przypadku niedoboru żelaza dochodzi do ograniczenia dostarczania tlenu do komórek, powodując osłabienie, zmęczenie, zmniejszenie odporności, wystąpienie duszności, nadwrażliwości na zimno i kołatanie serca [Saunders i in. 2013].

Żelazo występuje w żywności w dwóch postaciach: hemowej i niehemowej. Bogatym źródłem hemowej formy żelaza są produkty pochodzenia zwierzęcego, tj. podroby, mięso, drób, ryby, natomiast źródłem formy niehemowej produkty pochodzenia roślinnego: produkty zbożowe, głównie pełnoziarniste, warzywa i owoce oraz rośliny strączkowe [Jędrzejczak 2004]. Pomimo tak wielu źródeł żelaza w produktach pochodzenia roślinnego, wegetarianie są niezwykle narażeni na jego niedobór [Hunt 2003]. Dzieje się tak za sprawą osłabionego wchłaniania żelaza.

Jednymi ze związków hamujących wchłanianie niehemowego żelaza są fityniany znajdujące się w roślinach strączkowych, orzechach, pełnoziarnistych produktach zbożowych oraz nieprzetworzonych otrębach. Można przeciwdziałać tym związkom, poprzez spożywanie produktów, które nie zawierają w pełni przemielonych ziaren zbożowych. Dodatkowo długotrwałe moczenie i/ lub kiełkowanie nasion roślin strączkowych powoduje zmniejszenie zawartości fitynianów [Saunders 2013]. Innymi składnikami hamującymi wchłanianie żelaza (inhibitorami) są: błonnik, fosforany (znajdujące się w przetworzonych produktach spożywczych, m.in. napojach typu cola, zżelowanych owocach, dżemach, napojach czekoladowych, pieczywie cukierniczym itp.) oraz wapń i cynk [Jędrzejczak 2004].

Wegetarianie powinni stosować metody pozwalające na zwiększenie wchłaniania żelaza, poprzez łączenie go z czynnikami zwiększającymi absorbcję. Należą do nich witamina A i beta-karoten, kwasy cytrynowy i mlekowy, które znajdują się w produktach fermentowanych [Jędrzejczak, 2004]. Również witamina C sprzyja wchłanianiu żelaza, ułatwia przemianę $\mathrm{Fe}^{3+}$ do $\mathrm{Fe}^{2+}$ (formy lepiej przyswajalnej). Witamina $\mathrm{C}$ znajduje się w szeregu warzyw i owoców, produktach fermentowanych, sokach itp. [Saunders 2013].

\section{Podsumowanie}

Dieta wegetariańska jak każda inna może nieść za sobą negatywne skutki dla zdrowia związane z niedoborami żywieniowymi. Dlatego też ważne jest jej właściwe zbilansowanie zgodnie z zasadami prawidłowego żywienia. Ważne jest dostarczanie pełnowartościowych produktów spożywczych oraz urozmaicanie codziennych posiłków. Warto wziąć pod uwagę, że ta zasada dotyczy nie tylko osób stosujących dietę wegetariańską, ale również osób stosujących zarówno diety bardziej lub mniej restrykcyjne, jak i dietę konwencjonalną bez żadnych wykluczeń żywieniowych. 


\section{Bibliografia}

Ambroszkiewicz J., Klemarczyk W., Gajewska J., Chełchowska M., Franek E., Laskowska-Klita T., 2010. The influence of vegan diet on bone mineral density and biochemical bone turnover markers. Pediatr. Endocrinol. Diabetes Metab. 16 (3), 201-204.

Berkow S.E., Barnard N.D., 2005. Blood pressure regulation and vegetarian diets. Nutr. Rev. 63, 1-8. https://doi.org/10.1111/j.1753-4887.2005.tb00104.x

Berkow S.E., Barnard N., 2006. Vegetarian diets and weight status. Nutr Rev. 64(4), 175-186. https://doi.org/10.1111/j.1753-4887.2006.tb00200.x

Bolanowski J., Bolanowski M., 2005. Znaczenie wapnia i witaminy D w profilaktyce i leczeniu osteoporozy. Adv. Clin. Exp. Med. 14(5), 1057-1062.

Chabasińska M., Przysławski J., Lisowska A., Schlegel- Zawadzka M., Grzymisławski M., Walkowiak J., 2008. Typ i czas stosowania diety wegetariańskiej a surowicze stężenie witaminy B 12 . Przegl. Gastroenterol. 3(2), 63-67.

Chang-Claude J., Hermann S., Eilber U., Steindorf K., 2005. Lifestyle determinants and mortality in German vegetarians and health-conscious persons: results of a 21-year follow-up. Cancer Epidemiol. Biomark. Prev. 14, 963-968. https://doi.org/10.1158/1055-9965.EPI-04-0696

Craig W.J, 2009. Health effects of vegan diets. Am. J. Clin. Nutr. 89, 1627-1633. https://doi.org/10.3945/ajen.2009.26736N

Dolińska B., Mikulska A., Ryszka F., 2009. Promotory wchłaniania wapnia. Ann. Acad. Med. Siles 63(1), 76-83.

Gilsing A.M., Crowe F.L., Lloyd-Wright Z., Sanders T.A., Appleby P.N., Allen N.E., Key T. J., 2010. Serum concentrations of vitamin $B_{12}$ and folate in British male omnivores, vegetarians and vegans: results from a cross-sectional analysis of the EPIC-Oxford cohort study. Eur. J. Clin. Nutr. 64(9), 933-939. https://doi.org/10.1038/ejcn.2010.142

Ho-Pham L.T., Nguyen N.D., Nguyen T.V., 2009. Effect of vegetarian diets on bone mineral density: a Bayesian meta-analysis. Am. J. Clin. Nutr. 90, 943-950. https://doi.org/10.3945/ajcn.2009.27521

Hunt J.R., 2003. Bioavailability of iron, zinc and Rother trace minerale from vegtarian diets. Am. J. Clin. Nutr. 78(3), 633-639. https://doi.org/10.1093/ajcn/78.3.633S

Jarosz M., Rychlik E., Stoś K., Charzewska J. (red.), 2020. Normy żywienia dla populacji Polski i ich zastosowanie. NIZP-PZH, Warszawa, 48-67.

Jenkins D.J., Kendall C.W., Marchie A., Jenkins A.L., Augustin L.S., Ludwig D.S., Barnard N.D., Anderson J.W., 2003. Type 2 diabetes and the vegetarian diet. Am. J. Clin. Nutr. 78, 610S616S. https://doi.org/10.1093/ajcn/78.3.610S

Jędrzejczak R., 2004. Żelazo i mangan w żywności. Rocz. Państw. Zakł. Hig. 55, 13-20.

Joint WHO/FAO/UNU Experts Consultation, 2007. Protein and amino acid requirements in human nutrition. WHO Tech. Rep., Ser. 935, 1-265.

Khan N., Afaq F., Mukhtar H. 2008. Cancer chemoprevention through dietary antioxidants: Progress and promise. Antioxid. Redox. Signal. 10, 475-510. https://doi.org/10.1089/ars.2007.1740

Marsh K.A., Munn E.A., Baines S.K., 2013. Protein and vegetarian diets. Med. J Aust., 199(4), 710. https://doi.org/10.5694/mja11.11492

Nakos M., Pepelanova I., Beutel S., Krings U., Berger R.G., Scheper T. 2017. Isolation and analysis of vitamin $B_{12}$ from plant samples. Food Chem. 216, 301-308. https://doi.org/10.1016/j.foodchem.2016.08.037

Nazarewicz R., 2007. Wpływ stosowania diety wegetariańskiej na wybrane parametry morfologiczne i biochemiczne krwi. Rocz. Państw. Zakł. Hig. 58(1), 23-27.

Phillips F., 2005. Vegetarian nutrition. British Nutrition Foundation. Nutr. Bull. 30, $132-167$. https://doi.org/10.1111/j.1467-3010.2005.00467.x

Pilis W., Stec K., Zych M., Pilis A., 2014. Health benefits and risk associated with adopting a vegetarian diet. Rocz. Państw. Zakł. Hig. 65(1), 9-14.

Pyrzyńska E., 2013. Dieta wegetariańska w świetle zasad prawidłowego odżywiania - postawy zachowanie wegetarian w Polsce. Zesz Nauk. UEK 906, 27-36.

Renada M., Fischer P., 2010. Diety wegetariańskie dzieci i młodzieży. Pediatr. Dypl. 14(2), 68-75. 
Rosell M., Appleby P., Spencer E., Key T., 2006. Weight gain over 5 years in 21,966 meat-eating, fish-eating, vegetarian, and vegan men and women in EPIC-Oxford. Int. J. Obes. 30, 13891396. https://doi.org/10.1038/sj.ijo.0803305

Saunders A., Craig W.J., Baines S.K., Posen J.S., 2013. Iron and vegetarian diet. Med. J. Aust. 199(4), 11-16. https://doi.org/10.5694/mja11.11494

Sicińska E., Cholewa M., 2012. Ocena potrzeb i możliwości zwiększenia zawartości witaminy B 12 w diecie. Rocz. Państw. Zakł. Hig. 63(1), 67-71.

Wang F., Zheng J., Yang B., Jiang J., Fu Y., Li D., 2015. Effects of vegetarian diets on blood lipids: a systematic review and meta-analysis of randomized controlled trials. J. Am. Heart. Assoc. 27, e002408. https://doi.org/10.1161/JAHA.115.002408

Watanabe F., Takenaka S., Katsura H., Masumder S.A., Abe K., Tamura Y., Nakano Y. 1999. Dried green and purple lavers (Nori) contain substantinal amounts of biologically active vitamin $\mathrm{B}_{12}$ but less of dietary iodine relative to other edible seaweeds. J. Agric. Food Chem. 47, 23412343. https://doi.org/10.1021/jf981065c

Zdrojewicz Z., Chruszczewska E., Miner M., 2015. Wpływ witaminy D na organizm. Pediatr. Med. Rodz. 2(18), 61-66.

Zeuschner C.L., Hokin B.D., Marsh K.A., Saunders A.V., Reid M.A., Ramsay M.R., 2012. Vitamin $\mathrm{B}_{12}$ and vegetarian diets. Med. J. Aust. 1(2), 27-32. https://doi.org/10.5694/mja11.11509 
Natalia Kaniewska $^{1}$, Justyna Kupiec ${ }^{1}$

\section{Znaczenie bioaktywnych związków żywności w rozwoju i profilaktyce chorób neurodegeneracyjnych}

The importance of bioactive nutritional compounds in the development and prevention of neurodegenerative diseases

Związki bioaktywne występują naturalnie w przyrodzie lub powstają podczas przetwarzania żywności czy roślin leczniczych i pozytywnie wpływają na organizm człowieka. Neurodegeneracja odnosi się do postępującej i trwałej utraty neuronów w określonych obszarach mózgu i rdzenia kręgowego. Głównymi czynnikami wyzwalającymi neurodegenerację są stres oksydacyjny, nieprawidłowe odkładanie się białek w mózgu i tworzenie blaszek amyloidowych, uszkodzone funkcjonowanie mitochondriów, indukcja apoptozy, upośledzenie sieci proteostazy i stan zapalny układu nerwowego [Barbalace i in. 2019].

Celem pracy była analiza dostępnej literatury naukowej na temat znaczenia bioaktywnych związków żywności w rozwoju i profilaktyce chorób neurodegeneracyjnych.

\section{Triterpeny pentacykliczne}

Kwas ursolowy to triterpenoid występujący powszechnie w owocach jabłek (głównie w skórce) oraz liściach rozmarynu, szałwii, lawendy i tymianku [Orłowska-Majdak 2014]. Sugeruje się, że może on być pomocny w leczeniu choroby Alzheimera. Charakterystyczną cechą tej choroby jest agregacja $\beta$-amyloidu $(A \beta)$ w mózgu. $A \beta$ wiąże się $z$ mikroglejem poprzez kompleks receptorów, który obejmuje CD36, co prowadzi do produkcji prozapalnych cytokin i neurotoksycznych reaktywnych form tlenu, a następnie do neurodegeneracji. Z badań naukowych wynika, że kwas ursolowy może spowalniać rozwój choroby Alzheimera poprzez hamowanie aktywności receptorów CD36 komórek mikrogleju, które wiążą $\beta$-amyloid [Wilkinson i in. 2011].

Kwas oleanolowy występuje powszechnie w owocach oliwki, a także w kwiatach i liściach wielu innych roślin, np. melisy czy lawendy [Orłowska-Majdak 2014]. Martin $\mathrm{i}$ in. [2010] podczas badania przeprowadzonego na zwierzęcym modelu stwardnienia rozsianego, zauważyli przeciwzapalne działanie kwasu oleanolowego, prowadzącego do zmniejszenia objawów choroby. Dodatkowo na mysim modelu starzenia się wywołanego D-galaktozą wykazano, że kwas oleanolowy przeciwdziała glikacji w mózgach zwierząt, z którą to powiązana jest choroba Alzheimera. Końcowe produkty glikacji mogą bezpośrednio powodować apoptozę neuronów, działając jako neurotoksyny lub sprzyjając

\footnotetext{
${ }^{1}$ Uniwersytet Przyrodniczy w Lublinie, Wydział Nauk o Żywności i Biotechnologii, justyna_kupiec@wp.pl
} 
uszkodzeniom zapalnym. W badaniach dowiedziono, że kwas oleanolowy wykazuje działanie antyapoptyczne, co skłoniło autorów do wniosku, iż można go polecić jako środek o właściwościach hamujących proces starzenia [Yin 2012].

Kwas asjatowy występuje w wąkrocie azjatyckiej. Podczas badań na hodowlach komórkowych oraz na modelu zwierzęcym demencji wywołanej kwasem glutaminowym (Glu) wykazano, że kwas asjatowy ma zdolność redukowania aktywności wolnych rodników, które powstały w tych komórkach pod wpływem Glu. Spowalniał także proces apoptozy komórek neuronalnych, zmniejszał deficyty pamięciowe oraz sprowadzał do poziomu wyjściowego enzymy antyoksydacyjne w hipokampie i korze mózgowej zwierząt doświadczalnych. Kwas asjatowy może zmniejszać ryzyko zachorowania na AD, ponieważ wykazuje działanie protekcyjne w stosunku do $\beta$-amyloidu. Istnieją przesłanki do traktowania tego związku jako możliwego leku na choroby neurodegeneracyjne, jednak opublikowano też informację, że w dużych dawkach kwas asjatowy jest cytotoksyczny, dlatego jego pozytywne działanie jest uzależnione od dawki [Orłowska-Majdak 2014].

\section{Polifenole $\mathrm{i}$ inne antyoksydanty}

Badania wskazują, że polifenole są zdolne do modulowania funkcji komórkowych, które skutkują aktywną neuroprotekcją. Ich korzystne działanie może mieć związek ze zdolnością do redukcji stresu oksydacyjnego i ochroną cząsteczek sygnałowych. Przykładami takich związków są resweratrol z winogron i wina, kurkumina z kurkumy czy epigallokatechina z zielonej herbaty.

Resweratrol chroni przed chorobami neurodegeneracyjnymi i zmniejsza uszkodzenia oksydacyjne w błonach synaptycznych poprzez protekcję neuronów przed toksycznością wywoływaną substancją białkową - $\beta$-amyloidem [Di Meo i in. 2018], którego nadmierne gromadzenie się w błonie tłuszczowej otaczającej komórki nerwowe powoduje tworzenie się blaszek starczych. Złoża te blokują funkcjonowanie synaps, co uniemożliwia przekazywanie impulsów między komórkami nerwowymi [Młynarczyk i in. 2016].

Kurkumina to związek pochodzenia roślinnego, który jest głównym składnikiem kurkumy pozyskiwanej z kłącza ostryżu [Dochniak i Ekiert 2015]. Ma działanie antyagregacyjne w chorobach Parkinsona i Alzheimera. Wiąże włókna białek $\beta$-amyloidu oraz $\alpha$-synukleiny, która ulega agregacji i tworzeniu się nierozpuszczalnych złogów w strukturach nerwowych u osób cierpiących m.in. na AD i PD. Na podstawie badań wykazano, że ma ona działanie antyoksydacyjne (neutralizuje wolne rodniki i pełni rolę inhibitora syntazy tlenku azotu NOS) i przeciwzapalne (jest regulatorem cyklooksygenazy, głównie formy indukowanej COX-2 i lipooksygenazy LOX). Ponadto, hamuje pobudzenie jądrowego czynnika kappa-B, który aktywuje się przez połączenie peptydu $\beta$-amyloidu z receptorem p75NTR. Skutkuje to indukowaną apoptozą szkodliwego amyloidu. Zauważono również, że stosowanie kurkuminy znacznie zmniejsza toksyczność reaktywnych form tlenu (ROS) i $\alpha$-synukleiny. Takie właściwości kurkuminy są istotnym czynnikiem, który chroni komórki przed działaniem genoto- ksycznym i neurotoksycznym, a modulowanie aktywności wybranych czynników czy enzymów może mieć istotny wpływ na patomechanizmy odpowiedzialne za powstawanie chorób neurodegeneracyj- 
nych. Jedną z takich chorób jest stwardnienie rozsiane, które jest schorzeniem autoimmunologicznym dotykającym ośrodkowy układ nerwowy. Polega na demielinizacji osłonek nerwowych neuronów. Badania wykazały, że limfocyty T pomocnicze produkujące IL17 odgrywają istotną rolę w rozwoju stwardnienia rozsianego. Kurkumina redukuje przenikanie do rdzenia kręgowego komórek powodujących stan zapalny oraz ekspresję mRNA, cytokin IL-17, TGF- $\beta$, IL-6, IL-21, przez co zmniejsza stopień zaawansowania choroby [Czajkowski i Nazaruk 2014].

Epigallokatechina prawdopodobnie chroni neurony oraz enzymy niezbędne do przetwarzania białka prekursora $\beta$-amyloidu przed stresem oksydacyjnym. Wykazano, że spowalnia również osłabienie funkcji poznawczych związanych $\mathrm{z}$ wiekiem. Badania przeprowadzone na myszach wykazały, że jest ona w stanie poprawić procesy poznawcze i zdolność uczenia się oraz zmniejszać mózgową amyloidozę w chorobie Alzheimera [Di Meo $i$ in. 2018].

L-teanina jest niebiałkowym aminokwasem występującym w herbacie. Wykazuje działanie neuroprotekcyjne przez redukcję toksycznego działania glutaminianu, czyli neuroprzekaźnika odpowiedzialnego za transport jonów wapnia do wnętrza komórki. Zbyt wysoka koncentracja jonów wapnia w komórkach mózgowych powoduje zwiększenie stężenia wolnych rodników, co prowadzi do śmierci komórek nerwowych. L-teanina działa zatem jako antagonista glutaminianu, ze względu na podobieństwo strukturalne do jego cząsteczek, i zapobiega nadmiernemu napływowi kationów wapnia do wnętrza neuronów [Shu-Qing i in. 2018].

Kofeina to alkaloid warunkujący zdrowotne właściwości kawy. W zależności od dawki, poprawia ona funkcje poznawcze i stymuluje pracę układu nerwowego poprzez blokowanie receptorów adenozynowych $\mathrm{A}_{2} \mathrm{~A}$. Skutkuje to zwiększeniem poziomu dopaminy i ochroną neuronów dopaminergicznych przed degradacją, co thumaczy mechanizm działania kawy w przypadku choroby Parkinsona. Blokowanie tych recepto-rów we wczesnym stadium choroby Alzheimera zapobiega utracie synaps w hipokampie i zmniejsza częstotliwość deficytów pamięci [Tajik i in. 2017]. Paraksantyna, która jest jednym z metabolitów kofeiny, również wykazuje protekcyjny wpływ na neurony dopaminergiczne poprzez stymulowanie receptorów rianodynowych [Oñatibia-Astibia i in. 2017]. Metaanaliza 26 badań wykazała, że spożywanie 3 filiżanek kawy na dobę zmniejsza ryzyko rozwoju choroby Parkinsona o 25\% [Pelczyńska i Bogdański 2019].

Kwercetyna to związek fenolowy występujący w owocach i warzywach, np.: cebuli, jabłkach, jagodach, brokułach, pomidorach czy winogronach. Badania wykazały, że ma ona zdolność do redukcji wolnych rodników i zwiększania aktywności enzymów antyoksydacyjnych, chroniąc $\mathrm{w}$ ten sposób neurony przed stresem oksydacyjnym [Martin Ortega i Segura Campos 2019].

Kapsaicyna jest alkaloidem, który występuje w papryce rocznej z rodziny psiankowatych i papryczce chili. W jednym z badań poddano myszy działaniu glutaminianu, który wywołuje stres oksydacyjny. Po podaniu kapsaicyny zauważono przywrócenie prawidłowych funkcji komórek nerwowych, które były narażone na apoptozę. W połączeniu z resweratrolem zaobserwowano spotęgowanie jego właściwości neuroprotekcyjnych [Czajkowski i Nazaruk 2014]. 
6-Shogaol to bioaktywny związek pochodzący z imbiru, który skutecznie zmniejsza ekspresję cyklooksygenazy-2 - enzymu katalizującego syntezę substancji prozapalnej prostaglandyny. Wykazano, że związek ten ma podobne działanie do czynnika wzrostu komórek nerwowych, poprzez aktywację wewnątrzkomórkowych szlaków sygnałowych, stymuluje neurogenezę, stąd uważa się, że ma działanie profilaktyczno-terapeutyczne na choroby neurodegeneracyjne, zmniejsza stan zapalny i stymuluje regenerację neuronów.

Kwas rozmarynowy występujący w szałwii lekarskiej, podawany doustnie mysim modelom choroby Alzheimera, hamował oligomeryzację i odkładanie $\beta$-amyloidu i $\alpha$-synukleiny w mózgu. Może on zmniejszać deficyty pamięci oraz spowalniać procesy związane ze starzeniem się organizmu. Wykazuje właściwości przeciwutleniające, zmiata wolne rodniki i moduluje części wewnątrzkomórkowych kaskad prowadzących do śmierci neuronów [Pypno i Zdrojewicz 2015].

Witaminy $\mathbf{C}$ i $\mathbf{E}$ pełnią rolę przeciwutleniaczy w mózgu i ochraniają neurony przed skutkami stresu oksydacyjnego. Witamina $\mathrm{C}$ to kofaktor hydroksylaz, czyli enzymów ograniczających biosyntezę neuroprzekaźników. Pełni niezbędne funkcje w syntezie dopaminy i noradrenaliny i moduluje metabolizm tyrozyny. Dopamina jest zaangażowana w regulację uwagi i motywacji, koordynację ruchową i napięcie mięśni. Jej niskie stężenie w mózgu towarzyszy chorobie Parkinsona. Witamina E buduje błony neuronowe i jest silnym przeciwutleniaczem - zmiata wolne rodniki, zapobiega oksydacji lipidów i wielonienasyconych kwasów tłuszczowych w mózgu. Podobnie do kwasu askorbinowego, reguluje syntezę i działanie noradrenaliny, dopaminy i dodatkowo acetylocholiny [Goluch-Koniuszy i Fugiel 2016].

Witamina D $\mathbf{D}_{3}$ pełni rolę neuroprotekcyjną w chorobie Alzheimera, stwardnieniu rozsianym i chorobie Parkinsona. W przypadku AD zmniejsza ona kumulację $\beta$-amyloidu i odkładania blaszek amyloidalnych, zwiększa rozkład glukozy, zmniejsza stres oksydacyjny i nitrozacyjny oraz aktywność prozapalną i stymuluje system neuroprzekaźników w obszarze ośrodkowego układu nerwowego [Waszczyk-Nowaczyk i in. 2020]. Wykazuje działanie plejotropowe w obrębie układu nerwowego ze względu na obecność receptorów jądrowych VDR w neuronach i komórkach glejowych w regionach odpowiedzialnych za funkcje poznawcze. Wiązanie witaminy D z VDR chroni neurony przed skutkami degeneracyjnymi choroby [Bieniek i in. 2014].

\section{Witaminy z grupy B}

Witaminy z grupy B są istotnym elementem diety, który wspiera prawidłowe funkcjonowanie układu nerwowego. W wielu badaniach dowiedziono, że duże stężenie homocysteiny przyczynia się do występowania chorób neurodegeneracyjnych. Za prawidłowy metabolizm homocysteiny odpowiadają witaminy $\mathrm{B}_{12}, \mathrm{~B}_{6}$ oraz kwas foliowy. Witamina $B_{12}$ i kwas foliowy biorą udział w przemianach homocysteiny do metioniny, natomiast witamina $\mathrm{B}_{6}$ reguluje przemianę homocysteiny do cysteiny. Niedobory tych witamin prowadzą do podwyższonego poziomu homocysteiny w surowicy krwi, który w licznych badaniach został zaobserwowany u osób cierpiących na stwardnienie rozsiane oraz chorobę Alzheimera [Szczygieł i in. 2014, Li i in. 2020]. Prawidłowy poziom homocysteiny w osoczu waha się od $5 \mathrm{do} 15 \mu \mathrm{mol} / \mathrm{l}$. W badaniach wykazano, że zwiększenie 
zawartości tego aminokwasu o każde $5 \mu \mathrm{mol} / \mathrm{l}$ powyżej normy zwiększa ryzyko wystąpienia AD o 40\% [Szumilas i in. 2016].

Homocysteina zwiększa podatność neuronów na stres oksydacyjny, który jest jednym z czynników predysponujących do występowania chorób neurodegeneracyjnych. Ośrodkowy układ nerwowy zużywa duże ilości tlenu i cechuje się najwyższą aktywnością mitochondrialną, dlatego jest szczególnie wrażliwy na niekorzystne działanie stresu oksydacyjnego.

Powyższe przesłanki uzasadniają słuszność kontrolowania stężenia homocysteiny oraz uwzględniania w diecie źródeł witamin z grupy B w profilaktyce oraz terapii chorób neurodegeneracyjnych [Szczygieł $i$ in. 2014].

\section{Niezbędne nienasycone kwasy tluszczowe}

Kwasy tłuszczowe stanowią niezbędny składnik diety, bowiem są konieczne do prawidłowego funkcjonowania organizmu człowieka. Są głównym budulcem mózgu oraz układu nerwowego. Ponadto stanowią składnik błon komórkowych pozostałych elementów ustroju. Aksony komórek nerwowych są otoczone osłonką mielinową, która zbudowana jest głównie z tłuszczu. Przewodnictwo neuronalne, a także szybkość transmisji impulsów, uzależnione są od jakości osłonki mielinowej. Zbyt cienka lub uszkodzona osłonka mielinowa jest przyczyną spowolnienia komunikacji między neuronami lub nawet ją uniemożliwia [Wilczyńska 2012].

W chorobach Alzheimera oraz Parkinsona zaleca się spożywanie jednonienasyconych niezbędnych kwasów tłuszczowych (JNKT) oraz wielonienasyconych niezbędnych kwasów tłuszczowych (WNKT). Ich źródłem pokarmowym są oleje roślinne oraz tłuste ryby morskie [Dochniak i Ekiert 2015].

Wielonienasycone kwasy tłuszczowe pełnią rolę w sygnalizacji komórkowej, między innymi przez uczestnictwo w aktywacji systemu receptorów w odpowiedzi na wiązanie neurotransmitera. Biorą także udział $\mathrm{w}$ neurogenezie, synaptogenezie, a także w rozwoju wypustek nerwowych. Obecność kwasów tłuszczowych omega-3 i omega-6, powoduje wzrost aktywności cyklazy adenylowej i kinazy białkowej A, które uczestniczą $\mathrm{w}$ metabotropowych szlakach sygnalizacyjnych serotoniny, noradrenaliny oraz dopaminy, której to niskie stężenie w mózgu towarzyszy chorobie Parkinsona [Goluch-Koniuszy i Fugiel 2016].

Do tworzenia połączeń synaptycznych i zachowania plastyczności mózgu konieczna jest odpowiednia ilość DHA (kwasu dokozaheksaenowego). Pochodne DHA wykazują działanie przeciwzapalne oraz niwelują skutki działalności wolnych rodników. Takie działanie zapobiega uszkodzeniom oraz apoptozie komórek neuronalnych. Kwas dokozaheksaenowy wpływa również na utrzymanie w tkance mózgu dużego stężenia fosfatydyloseryny (PS), której odpowiednia zawartość w błonach komórkowych neuronów może zahamować ich apoptozę [Dochniak i Ekiert 2015].

Badania wykazały, że uwzględnienie $\mathrm{w}$ diecie WNKT z rodziny omega-3 częściej niż 2 razy w tygodniu może zmniejszyć wystąpienie AD o $60 \%$ w porównaniu z osobami, które nie spożywają tych kwasów. Spożywanie kwasów tłuszczowych z grupy omega-3 uznano za jeden z głównych czynników zmniejszających ryzyko rozwoju AD. Duże ilości 
DHA w diecie zapobiegają powstawaniu płytek amyloidowych oraz splotów neurofibrylarnych, które są typowe dla choroby Alzheimera [Dochniak i Ekiert 2015].

\section{Podsumowanie}

Wciąż poszukiwane są nowe metody prewencji oraz łagodzenia objawów chorób neurodegeneracyjnych. Według dostępnych wyników badań substancje bioaktywne zawarte w żywności mogą zapobiegać lub spowalniać przebieg patologicznych procesów w obrębie układu nerwowego. Naukowcy sugerują, że dieta bogata w antyoksydanty oraz nienasycone kwasy tłuszczowe jest czynnikiem ochronnym dla prawidłowej pracy układu nerwowego. Ponadto odpowiednia dieta stanowi wsparcie w farmakoterapii schorzeń neurodegeneracyjnych. Składniki bioaktywne żywności przeciwdziałają odkładaniu nieprawidłowych związków w obrębie mózgu, wpływają na prawidłową syntezę neuroprzekaźników oraz zmniejszają ryzyko wystąpienia zmian zwyrodnieniowych oraz zanikowych neuronów. Obecna wiedza na temat chorób neurodegeneracyjnych wciąż wymaga pogłębienia, aby móc wynaleźć skuteczny lek, dlatego tak istotna jest prewencja.

\section{Bibliografia}

Barbalace M.C., Malaguti M., Giusti L., Lucacchini A., Hrelia S., Angeloni C., 2019. Anti-inflammatory activities of marine algae in neurodegenerative diseases. Int. J. Mol. Sci., 20 (16), 3061 https://doi.org/10.3390/ijms20123061

Bieniek J., Brończyk-Puzoń A., Nowak J., Dittfeld A., Koszowska A., Kulik K., 2014. Witamina D - wskaźnik zdrowia u osób starszych w wybranych chorobach neurodegeneracyjnych. Geriatria, $8,49-55$.

Czajkowski P., Nazaruk J., 2014. Rola składników naturalnych w zapobieganiu chorobom neurodegeneracyjnym. Geriatria, 8, 258-263.

Di Meo F., Donato S., Di Pardo A., Maglione V., Filosa S., Crispi S., 2018. New therapeutic drugs from bioactive natural molecules: the role of gut microbiota metabolism in neurodegenerative diseases. Curr. Drug Met., 19(6), 478-489. https://doi.org/10.2174/1389200219666180404094147

Dochniak M., Ekiert K., 2015. Żywienie w prewencji i leczeniu choroby Alzheimera i choroby Parkinsona. Piel. Zdr. Publ. 5(2), 199-208.

Goluch-Koniuszy Z., Fugiel J., 2016. Rola składników diety w syntezie wybranych neurotransmiterów. Kosmos 65(4), 523-534.

Li X., Yuan J., Han J., Hu W., 2020. Serum levels of homocysteine, vitamin B12 and folate in patients with multiple sclerosis: an updeted meta-analysis. Int. J. Med.Sci. 17(6), 751-761. https://doi.org/10.7150/ijms.42058

Martin Ortega A., Segura Campos M.R., 2019. Bioactive compounds as therapeutic alternatives. W: Bioactive compounds. Health benefits and potential applications, Segura Campos M.R. (ed.). Woodhead Publ., Duxford, 247-264. https://doi.org/10.1016/B978-0-12-8147740.00013-X

Martín R., Carvalho-Tavares J., Hernández M., Arnés M., Ruiz-Gutiérrez V., Nieto M.L., 2010. Beneficial actions of oleanolic acid in an experimental model of multiple sclerosis: a potential therapeutic role. Biochem. Pharmacol. 79(2), 198-208. https://doi.org/10.1016/j.bcp.2009.08.002

Młynarczyk R., Bochon B., Piontek A., Kuner Ł., Sobiś J., Gorczyca P.W., 2016. Choroba Alzheimera - nowe strategie leczenia. Psychiatry 13(4), 210-214.

Oñatibia-Astibia A., Franco R., Martínez-Pinilla E., 2016. Health benefits of methylxanthines in neurodegenerative diseases. Mol. Nutr. Food Res. 61(6). doi:10.1002/mnfr.201600670 
Orłowska-Majdak M., 2014. Neuroprotekcyjne właściwości związków pochodzenia roślinnego: triterpeny pentacykliczne. Psychiatr. Psychol. Klin. 14(4), 284-289. https://doi.org/10.15557/PiPK.2014.0038

Pelczyńska M., Bogdański P., 2019. Prozdrowotne właściwości kawy. Varia Med., 10(3), $112-120$.

Pypno D., Zdrojewicz Z., 2015. Potencjalne wykorzystanie substancji pochodzenia roślinnego w leczeniu choroby Alzheimera. Pediatr. Med. Rodz. 11(3), 289-294. https://doi.org/10.15557/PiMR.2015.0027

Shu-Qing Ch., Ze-Shi W., Yi-Xiao M., Wei Z., Jian-Liang L., Yue-Rong L., Xin-Qiang Z., 2018. Neuroprotective effects and mechanisms of tea bioactive components in neurodegenerative diseases. Molecules 23(3), 512, 1-17. https://doi.org/10.3390/molecules 23030512

Szczygieł B., Gaweł M., Ukleja A., Boniecka I., 2014. Rola wybranych składników odżywczych we wspomaganiu leczenia farmakologicznego choroby Alzheimera. Med. Wieku Podeszłego 4 (1), 7-15.

Szumilas K., Szumilas P., Kłódka D., Garczyński W., 2016. Metody oddziaływań niefarmakologicznych u pacjentów z chorobą Alzheimera. W: Horyzonty współczesnej fizjoterapii, Borowicz, A.M., Osińska A.M. (red.). WSEiT, Poznań, 181-193.

Tajik N., Tajik M., Mack I., Enck P., 2017. The potential effects of chlorogenic acid, the main phenolic components in coffee, on health: a comprehensive review of the literature. Eur. J. Nutr. 56(7), 2215-2244. https://doi.org/10.1007/s00394-017-1379-1

Waszyk-Nowaczyk M., Główka E., Superczyńska S., Spitzka K., Guzenda W., Sadowski B., Falana A., Staś D., 2020. Rola witaminy D w chorobach nowotworowych i neurodegeneracyjnych przegląd literatury. Farm. Pol. 76(3). doi:10.32383/farmpol/121024

Wilczyńska A., 2012. Kwasy thuszczowe w diecie człowieka a jego funkcjonowanie poznawcze i emocjonalne. Neuropsychiatr. Neuropsychol. 7(1), 35-42.

Wilkinson K., Boyd J.D., Glicksman M., Moore K.J., El Khoury J., 2011. A high content drug screen identifies ursolic acid as an inhibitor of amyloid $\beta$ protein interactions with its receptor CD36. J. Biol. Chem. 286(40), 34914-34922. https://doi.org/10.1074/jbc.M111.232116

Yin M.C., 2012. Anti-glycative potential of triterpenes: A mini-review. BioMedicine (1), 2-9. https://doi.org/10.1016/j.biomed.2011.12.001 
Małgorzata Kawalec ${ }^{1,2}$, Aleksandra Garbacz ${ }^{1,2}$, Marta Dec $^{2}$

\section{Nietolerancja laktozy - przyczyny i diagnostyka}

Lactose intolerance - causes and diagnosis

Nietolerancja laktozy to dolegliwość, która jest wynikiem pierwotnego lub wtórnego deficytu enzymu hydrolizującego cukier - laktazy. Objawia się występowaniem odpowiedzi ze strony układu pokarmowego w postaci bólów brzucha, wzdęć oraz biegunek na skutek fermentacji w okrężnicy niewchłoniętej laktozy [Deng i in. 2015, Leis i in. 2020]. W diagnostyce schorzenia stosuje się różne testy laboratoryjne, m.in. oznaczanie aktywności laktazy w wycinkach jelita czczego, test na tolerancję laktozy (test obciążania laktozą), testy genetyczne oraz wodorowe testy oddechowe [Deng i in. 2015].

Celem pracy było przedstawienie aktualnych informacji na temat klasyfikacji i mechanizmu nietolerancji laktozy, sposobów diagnostyki choroby oraz metod prewencji z wykorzystaniem mikroorganizmów probiotycznych.

\section{Laktoza i laktaza}

Laktoza, inaczej 4-0- $\beta$-galaktozydo( $\alpha$-D-glukopiranoza, zaliczana jest do grupy dwucukrów. Charakteryzuje się słabą rozpuszczalnością w wodzie oraz mniejszą słodkością w porównaniu z innymi sacharydami należącymi do tej grupy. Strukturę disacharydu utrwala wiązanie $\beta$-1,4-glikozydowe, które łączy dwie podjednostki: glukozę oraz galaktozę [Kowalewska-Piontas i Bednarski 1999]. Laktoza występująca w mleku ogółu ssaków, z wykluczeniem lwa morskiego, u którego obecność tego dwucukru nie została wykazana, stanowi kluczowe dla życia źródło energii [Zatwarnicki 2014, Deng i in. 2015]. Cukier mleczny stanowi około 7\% suchej masy mleka ludzkiego, a mleko krowie zawiera około $5 \%$ laktozy. Dwucukier ten występuje także w różnych produktach mlecznych [Hertzler 2008].

Wchłanianie laktozy odbywa się w jelitach, gdzie zachodzi hydroliza składowych disacharydu do monosacharydów (glukozy i galaktozy) za pomocą enzymu rąbka szczoteczkowego jelita cienkiego $\beta$-D-galaktozydazy [Kowalewska-Piontas i Bednarski 1999]. Zarówno glukoza, jak i galaktoza pełnią ważną funkcję w organizmie ssaków. Glukoza jest źródłem energii, zaś galaktoza bierze udział w odporności, przekazywaniu informacji między komórkami i rozwoju układu nerwowego u noworodków [Szilagyi i Ishayek 2018].

${ }^{1}$ Uniwersytet Przyrodniczy w Lublinie, Wydział Nauk o Żywności i Biotechnologii, Studenckie Koło Naukowe Biotechnologów „Biom”

${ }^{2}$ Uniwersytet Przyrodniczy w Lublinie, Wydział Medycyny Weterynaryjnej, malgorzata199@onet.pl 
Laktaza potocznie znana jako hydrolaza laktazy-florizyny (ang. lactase-phlorizin hydrolase, LPH), którą u ludzi można zidentyfikować już w 8. tygodniu życia płodowego. Aktywność enzymu rośnie do 34. tygodnia ciąży, a swoje apogeum osiąga tuż przed narodzinami. Zdolność trawienia cukru mlekowego w okresie karmienia piersią jest konieczne dla prawidłowego rozwoju i zdrowia niemowlęcia. Wynikiem zbyt późnego stwierdzenia wrodzonego niedoboru laktazy może być śmierć organizmu, dlatego ważna jest wczesna diagnostyka schorzenia [Vonk i in. 2012, Deng $i$ in. 2015].

\section{Klasyfikacja i mechanizm nietolerancji laktozy}

Występują trzy postaci nietolerancji laktozy: pierwotna, wtórna i wrodzona. Forma pierwotna jest identyfikowana najczęściej. Objawia się spadkiem aktywności laktazy. U osób dorosłych częstość występowania enzymu zależy od pochodzenia etnicznego i miejsca zamieszkania. Niskie stężenie laktazy można zaobserwować u ludzi zamieszkujących Europę Północną i Środkową, mieści się ono w granicach 5-15\%, zaś największe stężenie zidentyfikowano u osób mieszkających na następujących kontynentach: Afryka, Azja i Ameryka Południowa. Duży niedobór enzymu w Europie został powiązany z uczestnictwem dwóch polimorfizmów pojedynczego nukleotydu SNP (z ang. single nucleotide polymorphism): C / T-13910 i G / A-22018, ze względu na to, że uczestniczą one w regulacji stężenia laktazy po okresie niemowlęcym [Leis i in. 2020].

Istnieje również wtórny deficyt laktazy, przejawiający się nietrwałym, okresowym stanem, którego najczęstszą przyczyną jest zanikanie kosmków jelitowych, w wyniku czego powstają schorzenia układu pokarmowego, w tym ostrego zapalenia żołądka i choroby Leśniowskiego-Crohna. Zanik enzymu może być skutkiem przebytej wcześniej antybiotykoterapii czy przyjmowania kwasu acetylosalicylowego. Jednak w każdym przypadku skutkiem deficytu laktazy jest uniemożliwienie rozkładu laktozy i odkładanie jej w przewodzie jelitowym, niosące za sobą szereg dolegliwości [Cielecka 2010]. Zaleganie disacharydu spowodowane brakiem wchłaniania zwiększa ładunek osmotyczny przy jednoczesnym zwiększeniu zawartości wody w jelicie grubym, co prowadzi do występowania biegunek [Deng i in. 2015].

Wrodzoną nietolerancję laktozy można wykryć u noworodków. Ten typ jest szczególnie ciężkim stanem. Towarzyszące mu wodniste biegunki występujące po spożyciu mleka działają destrukcyjnie, prowadząc do opóźnienia wzrostu, odwodnienia oraz zasadowicy. Badanie na obecność lub brak laktazy przeprowadza się przez podanie mleka i obserwację odpowiedzi organizmu. Wystąpienie objawów charakterystycznych dla schorzenia jest podstawą do stwierdzenia nieobecności laktazy. Wczesna diagnoza jest kluczowa, aby w jak największym stopniu zminimalizować skutki wrodzonego braku enzymu [Fassio i in. 2018, Leis i in. 2020].

Inną równie uciążliwą przypadłością jest gromadzenie się gazów w jelitach. Mikrobiom jelita grubego charakteryzuje się zdolnością do łatwego fermentowania laktozy. Proces ten prowadzi do powstawania krótkołańcuchowych kwasów tłuszczowych oraz gazu (w głównej mierze $\left.\mathrm{H}_{2}\right)$, metanu $\left(\mathrm{CH}_{4}\right)$ oraz dwutlenku węgla $\left(\mathrm{CO}_{2}\right)$. Powstawanie gazów występuje nie tylko podczas fermentowania laktozy, ale i innych związków słabo wchłanialnych, takich jak oligosacharydy, monosacharydy, disacharydy oraz poliole. Zachodzące procesy związane $\mathrm{z}$ niedostatecznym przyswajaniem substancji wszechobecnych w diecie potęgują objawy nadwrażliwości jelita grubego [Deng i in. 2015]. 


\section{Diagnostyka}

Wyznacznikiem w zdiagnozowaniu nietolerancji laktozy nie mogą być jedynie dolegliwości żołądkowo-jelitowe, gdyż te objawy mogą mieć różne podłoże. Kluczową rolę $\mathrm{w}$ analizie schorzenia odgrywają badania laboratoryjne. Obecnie istnieje kilka metod pozwalających na stwierdzenie występowania zaburzeń związanych z nieprawidłowym wchłanianiem laktozy (ryc. 1) [Deng i in. 2015, Robles i Priefer 2020].

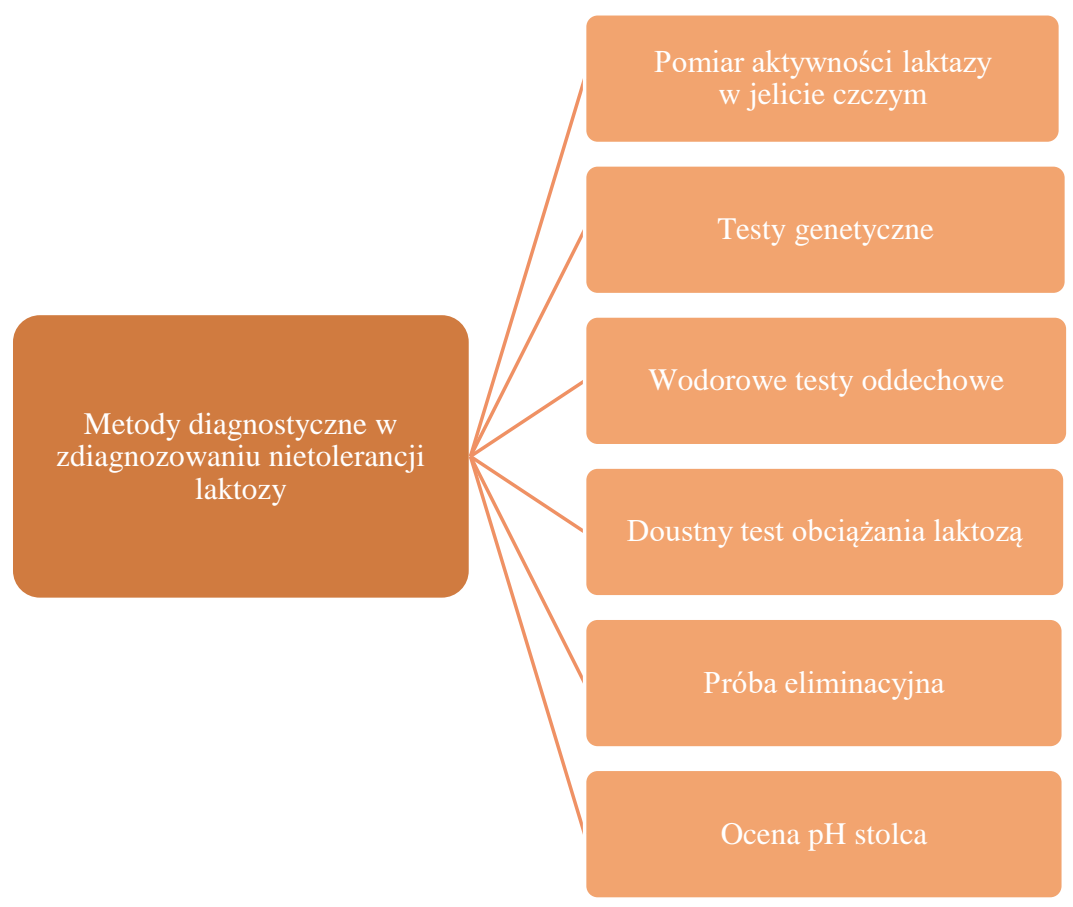

Ryc. 1. Metody diagnostyczne w identyfikacji nietolerancji laktozy Źródło: oprac. wł. na pods. Fidler i in. [2009], Deng i in. [2015], Robles i Priefer [2020]

Jedną z nich jest pomiar aktywności laktazy w jelicie czczym poprzedzony wcześniejszą biopsją fragmentów błony śluzowej jelita cienkiego. Metoda ta stanowi wzorzec odniesienia dla pierwotnego niedoboru laktazy. Analiza pozwala wykluczyć inne choroby powodujące wtórny niedobór laktazy, który działa destrukcyjnie na przewód pokarmowy. Wadą przedstawionej techniki jest jej inwazyjność oraz wysoki koszt. Istnieje również prawdopodobieństwo, że test może dawać fałszywie ujemne wyniki, spowodowane nierównomierną ekspresją enzymu.

Kolejnym sposobem na zdiagnozowanie nietolerancji jest doustny test obciążania laktozą (ang. lactose tolerance test, LTT), który wymaga pobrania próbek krwi od pacjenta. Polega on na prowokacji odpowiedzi organizmu na laktozę. Przed badaniem podaje się wzorcową dawkę laktozy. Za cel przedstawionego testu przyjmuje się pomiar glukozy we krwi, która powstaje w wyniku hydrolizy disacharydu. Krew pobiera się w 
pewnych odstępach czasowych i w określonych momentach trwania analizy, aby móc określić stężenie glukozy po przyjęciu doustnej dawki cukru mlecznego. Gdy laktoza ulega prawidłowemu trawieniu, następuje wzrost glikemii o $20 \mathrm{mg} \%$ od wartości zmierzonej na czczo. Jeżeli po spożyciu laktozy nie pojawił się wzrost glikemii, wtedy można stwierdzić, że dany pacjent cierpi na nietolerancję laktozy. Za wynik pozytywny testu przyjmuje się maksymalny wzrost stężenia glukozy w osoczu o $1,1 \mathrm{mmol} / \mathrm{l}$ lub mniej. Jednak istnieją także wady tej metody. Jedną z nich jest fałszowanie wyników u osób chorych na cukrzycę, u których występują wahania poziomu cukru po spożyciu posiłku. Przedstawiona metoda charakteryzuje się niską czułością oraz niską specyficznością przez co jest rzadko używana.

Do wykrywania nietolerancji laktozy wykorzystuje się również testy genetyczne oparte na analizie sekwencji DNA. U ludzi rasy kaukaskiej spadek aktywności laktazy obserwowany z wiekiem jest ściśle związany z polimorfizmem pojedynczego nukleotydu $\mathrm{C} / \mathrm{T}^{-13910}$ w obszarze intronu genu MCM6 związanego z ekspresją genu laktazy. W innych grupach etnicznych również odnotowano korelację pomiędzy określonymi mutacjami punktowymi a nietolerancją laktozy, jednak w przypadku tych wariantów genetyczne testy diagnostyczne są mniej popularne. Wśród polimorfizmów zlokalizowanych w genie LCT oraz w jego obrębie wymieniono również regiony G/A-22018 występujące u ludności populacji fińskiej, które mają związek aż w $95 \%$ z nietrwałą aktywnością enzymu. Niestety testy rutynowe dla tych wariantów nie są jeszcze ogólnodostępne. W kolejnym przypadku stwierdzono, że poziom trwałości laktazy jest uzależniony od występowania kilku rodzajów mutacji punktowych występujących w różnych populacjach. U ludności Arabii Saudyjskiej stwierdzono obecność polimorfizmu $\mathrm{G}^{-13915}$, zaś w plemionach Afrykańskich: $\mathrm{G}^{-14010}, \mathrm{G}^{-13915} \mathrm{i} \mathrm{G}^{-13907}$. Dzięki przeprowadzonym analizom sekwencji DNA można przyjąć, że trwałość enzymu przyczyniającego się do wchłaniania laktozy została wykreowana niezależnie w różnych rejonach świata na drodze ewolucji.

Podstawę do wykonania testu genetycznego u człowieka innej rasy niż kaukaska stanowi podejrzenie wrodzonego niedoboru laktazy, który występuje u noworodków. Procedura może być wykorzystana w przypadku wystąpienia objawów żołądkowo-jelitowych oraz po stwierdzeniu pozytywnej odpowiedzi organizmu na wykluczenie laktozy z diety [Fazeli i in. 2015, Robles i Priefer 2020].

Wodorowe testy oddechowe (ang. hydrogen breath tests, HBT) są najczęściej stosowanymi testami w diagnostyce nietolerancji laktozy. Ich zaletami są: niski koszt, nieinwazyjność oraz wysoka czułość. Metoda ta opiera się na badaniu poziomu $\mathrm{H}_{2}$ w wydychanym powietrzu. Mechanizm wytwarzania wodoru podczas fermentacji laktozy w okrężnicy jest związany z jej wcześniejszym niestrawieniem. Podczas tego procesu powstają liczne gazy, wśród których wyróżnia się wodór, a a jego większe stężenie może świadczyć o nietolerancji laktozy [He i in. 2006]. Gaz może przepływać przez błonę śluzową jelit, skąd trafia do krwioobiegu, a następnie zostaje wydalony przez układ oddechowy. Oprócz $\mathrm{H}_{2}$ ważną rolę w stwierdzeniu nietolerancji laktozy odgrywają inne gazy, takie jak metan czy dwutlenek węgla, ponieważ występuje korelacja pomiędzy wzrostem ich stężenia, a nasileniem nietolerancji. Ważnym aspektem związanym z przeprowadzeniem analizy HBT związanej z badaniem zawartości wodoru w wydychanym powietrzu są ograniczenia, których należy przestrzegać, aby test dał wiarygodny wynik [Robles i Priefer 2020]. Rezaie i in. [2017] opracowali konkretne zalecenia co do stylu życia i dzia- 
łania wybranych leków mogących mieć wpływ na przebieg badania. Uznano, że farmaceutyki dostępne na receptę oraz leki OTC (z ang. over the counter) dostępne bez recepty, takie jak antybiotyki, probiotyki, leki pobudzające i przeczyszczające jelita mogą mieć negatywny wpływ na wynik testu. Zaleca się zaprzestania przyjmowania antybiotyków na 4 tygodnie przed przystąpieniem do badania. Eliminacja bakterii fermentujących cukier mleczny (na skutek antybiotykoterapii) uniemożliwia określenie stężenia metanu oraz wodoru w wydychanym powietrzu właściwe dla stanu fizjologicznego. Bez zapewnienia odpowiedniej mikrobioty jelitowej test staje się bezużyteczny. Działanie zafałszowujące stężenie gazów mają także środki przeczyszczające, które mogą nadmiernie zwiększyć ich ilość oraz gromadzenie [Razaie i in. 2017]. Znaczący wpływ na wynik testu HBT ma również codzienny styl życia [Fassio i in. 2018]. Stwierdzono, że palenie tytoniu wpływa na stężenie wodoru oraz dwutlenku węgla w wydychanym powietrzu, a także przyczynia się do opóźnienia opróżniania żołądka i powstawania wrzodów, które powodują dodatkowe dolegliwości. Przed wykonaniem testu należy ograniczyć aktywność fizyczną, która związana jest $\mathrm{z}$ hiperwentylacją. $\mathrm{W}$ tym procesie zaburzeniu ulega ilość wodoru w wydychanym powietrzu w stosunku do stanu rzeczywistego, dając niewiarygodny wynik testu [Perman i in. 1985, Robles i Priefer 2020].

Kolejną metodą diagnostyki nietolerancji laktozy jest próba eliminacyjna, która charakteryzuje się wprowadzeniem diety bezlaktozowej. Uznano, że w przypadku, gdy po 2 tygodniach ustąpią objawy charakterystyczne dla nietolerancji laktozy, można stwierdzić o obecności tego zaburzenia u pacjenta.

Ostatnia technika identyfikacji nietolerancji laktozy opiera się na pomiarze $\mathrm{pH}$ stolca. Osoby u których występuje owa dolegliwość pH stolca ma odczyn kwasowy. Prawidłowe $\mathrm{pH}$ stolca u niemowląt wynosi około 5-5,5, zaś u dzieci i osób dorosłych 7-7,5 [Fidler i in. 2009].

\section{Probiotyki i prebiotyki w lagodzeniu klinicznych objawów nietolerancji laktozy}

Zgodnie z definicją Food and Agricultural Organization (FAO) oraz World Health Organization (WHO) ,probiotyki to żywe mikroorganizmy, które podawane w odpowiedniej ilości wywierają korzystny wpływ na zdrowie gospodarza” [Gałecka i in. 2018]. W skład probiotyków wchodzą różne szczepy probiotyczne, które wywodzą się od określonych gatunków bakterii przedstawionych na rycinie 2 .

Probiotyki stymulują rozwój korzystnej mikroflory jelitowej i wykazują działanie antagonistyczne w stosunku do bakterii potencjalnie patogennych i patogennych, a także wspomagają trawienie laktozy [Zommiti i in. 2020]. Efekt terapii probiotykami może wystapić w dwóch sytuacjach. Pierwsza to wspomaganie rozkładu laktozy podczas produkcji wyrobów mlecznych, co daje możliwość spożywania mleka i ogranicza skutki uboczne. Drugą jest działanie, które probiotyki wykazują w jelicie cienkim podczas fermentacji zachodzącej w okrężnicy [Vonk i in. 2012]. Szczepy probiotyczne przez swoją zdolność do hydrolizy laktozy przyczyniają się do zmniejszenia jej stężenia w produktach mlecznych, a działając wewnątrz organizmu gospodarza, znacznie poprawiają zachodzące procesy hydrolityczne w jelicie cienkim. Spożywanie produktów fermentowanych, takich jak jogurty, może znacznie poprawić jakość życia osób dotkniętych zaburzeniami wchłaniania laktozy. Za możliwe działanie hydrolityczne szczepów probiotycznych 


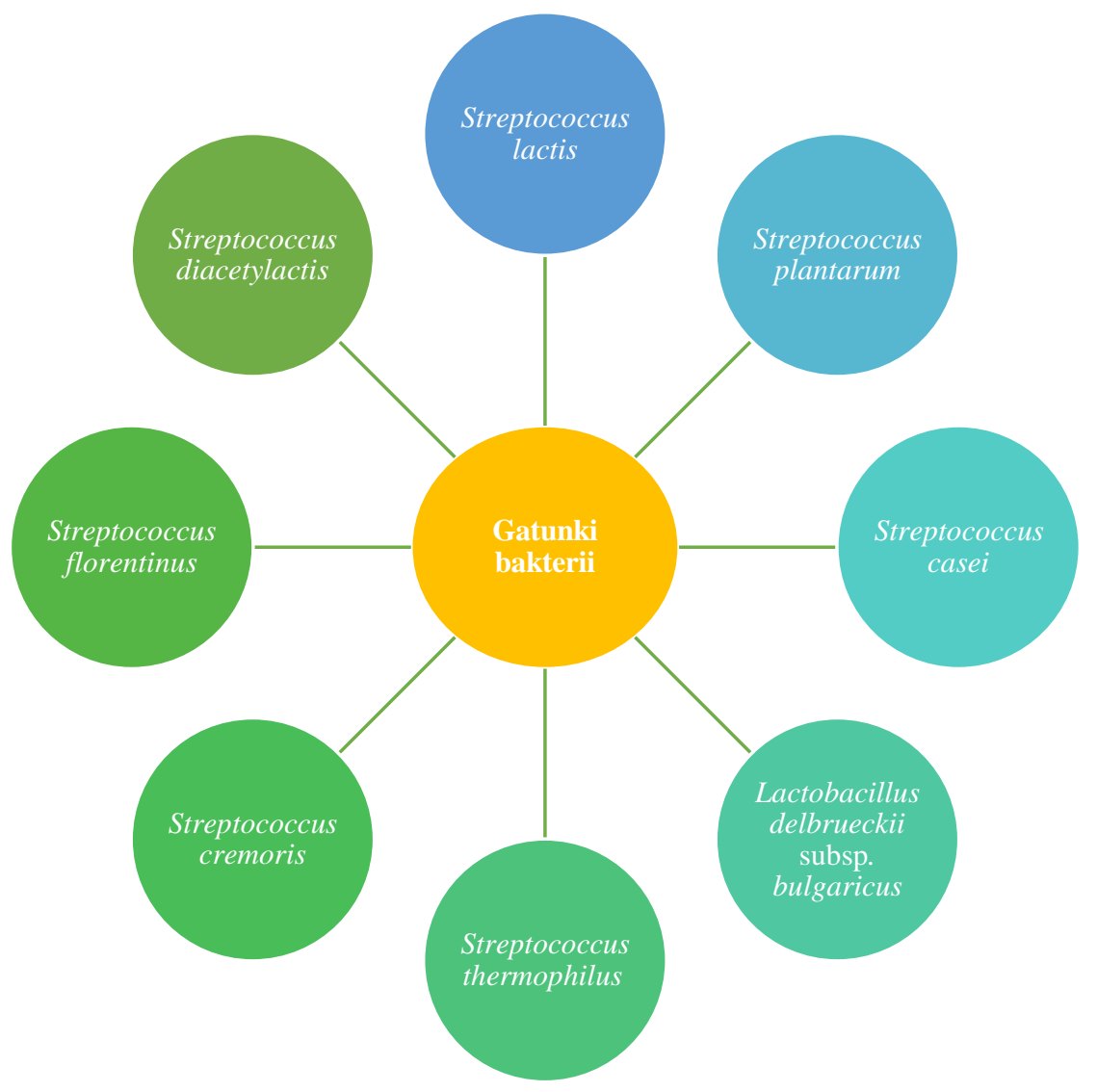

Ryc. 2. Gatunki bakterii, z których wywodzą się szczepy probiotyczne stosowane w łagodzeniu objawów nietolerancji laktozy

Źródło: oprac. wł. na podst. Zommiti i in. [2020]

odpowiada aktywność bakteryjnej $\beta$-galaktozydazy, która jest dostarczana przez spożywanie produktów fermentowanych lub preparatów probiotycznych. Stwierdzono, że enzym pochodzący od bakterii wykazuje lepszą wytrzymałość na kwasowość żołądka w porównaniu z syntetycznie otrzymanym produktem. Powodem wyjaśniającym zjawisko jest ochrona enzymu przez zamknięcie go w komórce bakteryjnej [Pakdaman i in. 2016]. Laktaza ulega pasażowi żołądkowemu, a następnie jest transportowana i uwalniana przez sole żółciowe do jelita cienkiego. Korzystne działanie produktów fermentowanych związane jest także $\mathrm{z}$ ich zdolnością do poprawiania trawienia oraz wydłużenia czasu opróżniania żołądka. Opóźniony cykl przejścia laktozy do kolejnych odcinków układu łagodzi objawy nietolerancji oraz daje resztkową aktywność $\beta$-galaktozydazy w jelicie cienkim, w wyniku czego czas na rozkład jest dłuższy. Dłuższy czas opróżniania żołądka wynika z większej lepkości oraz niższego $\mathrm{pH}$ w porównaniu z mlekiem oraz wyższej wartości energetycznej produktów fermentowanych zestawiając je z czystymi roztworami laktozy 
[De Vrese i in. 2001, Vonk i in. 2012]. Pakdaman i in. [2016] wykazali korzystne działanie szczepu Lactobacillus acidophilus DDS u osób z nietolerancją laktozy. Probiotyk trwale zasiedlał przewód pokarmowy i niwelował u pacjentów dolegliwości żołądkowojelitowe pojawiające się w następstwie prowokacji laktozą. Złagodzenia objawów ze strony układu pokarmowego nie odnotowano w grupie osób, którym podawano placebo.

\section{Podsumowanie}

Nietolerancja laktozy wynika z niedoboru lub braku enzymu hydrolizującego laktozę zwanego laktazą. Deficyt tego białka może mieć związek z różnymi czynnikami, które powodują pierwotną, wtórną i wrodzoną postać schorzenia. Kluczową rolę pełni wczesna diagnostyka, mająca na celu zminimalizować skutki niedoboru enzymu. Uciążliwe objawy choroby są podstawą do pracy nad sposobami prewencji, które w przyszłości mogą pomóc wielu pacjentom.

\section{Bibliografia}

Cielecka E.K., Dereń K., Grzegorczyk A. (red.), 2010. Nadwrażliwość pokarmowa. Alerg. Astma Immunol. 15(3), 118-124.

De Vrese M., Stegelmann A., Richter B., Fenselau S., Laue C., Schrezenmeir J. (red.), 2001. Probiotics - compensation for lactase insufficiency. Am. J. Clin. Nutr. 73(2), 421-429. https://doi.org/10.1093/ajen/73.2.421s

Deng Y., Misselwitz B., Dai N., Fox M. (red.), 2015. Lactose intolerance in adults: biological mechanism and dietary management. Nutrients 7(9), 8020-8035. https://doi.org/10.3390/nu7095380

Fassio F., Facioni M., Guagnini F., 2018 (red.). Lactose maldigestion, malabsorption, and intolerance: a comprehensive review with a focus on current management and future perspectives. Nutrients 10(1599), 1-12. https://doi.org/10.3390/nu10111599

Fazeli W., Kaczmarek S., Kirschstein M., Santer R. (red.), 2015. A novel mutation within the lactase gene ( $L C T)$ : the first report of congenital lactase deficiency diagnosed in Central Europe. BMC Gastroenterol. 15(90), 1-4. https://doi.org/10.1186/s12876-015-0316-0

Fidler E., Lisowska A., Walkowiak J. 2009. Nietolerancja laktozy - klasyfikacja i diagnostyka. Pediatr. Pol. 84(6), 562-566. https://doi.org/10.1016/s0031-3939(09)70089-7

Gałecka M., Basińska A.M., Anna Bartnicka A. (red.), 2018. Probiotyki — implikacje w praktyce lekarza rodzinnego. Forum Med. Rodz. 12(5), 170-182.

He T., Priebe M.G,. Harmsen H.J.M., Stellaard F., Sun X., Welling G.J. (red.), 2006. Colonic fermentation may play a role in lactose intolerance in humans. J Nutr. 136(1), 58-63. https://doi.org/10.1093/jn/136.1.58

Hertzler S., Savaiano D.A., Dilk A., Jackson K.A., Bhriain S.N., Suarez F.L., 2008. Nutrient considerations in lactose intolerance. $\mathrm{W}$ : Nutrition in the prevention and treatment of disease second edition, Coulston A.N., Boushey C.J. (red.). Elsevier, China, 755-770. https://doi.org/10.1016/B978-012193155-1/50039-8

Kowalewska-Piontas J., Bednarski W. (red.), 1999. Technologiczne oraz żywieniowe aspekty enzymatycznej hydrolizy laktozy. ŻNTJ 4(21), 54-61.

Leis R., De Castro M.- J., De Lamas C., Picáns R., Couce M. L. (red.), 2020. Effects of prebiotic and probiotic supplementation on lactase deficiency and lactose intolerance: a systematic review of controlled trials. Nutrients 12(1487), 1-13. https://doi.org/10.3390/nu12051487 
Pakdaman M.N., Udani J.K., Molina J.P., Shahani M. (red.), 2016. The effects of the DDS - 1 strain of lactobacillus on symptomatic relief for lactose intolerance - a randomized, double -blind, placebocontrolled, crossover clinical trial. Nutr J. 15(56) 2-10. https://doi.org/10.1186/s12937-016-0172-y

Perman J.A., Modler S., Engel R.R., Heldt G. (red.), 1985. Effect of ventilation on breath hydrogen measurements. J. Lab. Clin. Med. 105(4), 436-439.

Rezaie A., Buresi M., Lembo A., Lin H., McCallum R., Rao S., Schmulson M., Valdovinos M., Zakko S., Pimentel M. (red.), 2017. Hydrogen and methane-based breath testing in gastrointestinal disorders: the north american consensus. Am. J. Gastroenterol. 112(5), 775-784. https://doi.org/10.1038/ajg.2017.46

Robles L., Priefer R. (red.), 2020. Lactose intolerance: what your breath can tell you. Diagnostics 10(412), 1-11. https://doi.org/10.3390/diagnostics 10060412

Szilagyi A., Ishayek N. (red.), 2018. Lactose intolerance, dairy avoidance, and treatment options. Nutrients 10(1994), 1-30. https://doi.org/10.3390/nu10121994

Vonk R.J, Reckman G.A.R., Harmsen H.J.M., Priebe M.G., 2012. Probiotics and lactose intolerance. W: Probiotics, Rigobelo E.C. (red.). IntechOpen, United Kingdom. https://doi.org/10.5772/51424

Zatwarnicki P. (red.), 2014. Nietolerancja laktozy - przyczyny, objawy, diagnostyka. Piel. Zdr. Publ. 4(3), 273-276.

Zommiti M., Feuilloley M.G.J., Connil N. (red.), 2020. Update of probiotics in human world: a nonstop source of benefactions till the end of time. Microorganisms 8(1907), 1-33. https://doi.org/10.3390/microorganisms 8121907 
Kaja Kiersnowska $^{1}$, Gabriela Gutowska ${ }^{1}$

\section{Substancje psychoaktywne jako nowoczesna metoda leczenia zaburzeń psychicznych}

Psychoactive substances as a modern method of treating mental disorders

Badania na substancjach psychoaktywnych rozpoczęto ok. drugiej połowy XX w. Przeprowadzone wtedy eksperymenty wykazywały potencjał psychoterapeutyczny tych substancji w leczeniu chorób psychicznych. Opublikowano wówczas ponad 1000 prac, w których wzięło udział ponad 40 tys. pacjentów. W latach 1970-1990 badania zostały wstrzymane na skutek rozpowszechnienia substancji psychoaktywnych wśród różnych grup kulturowych, co prowadziło do nadużyć. W efekcie powstała negatywna opinia o substancjach psychoaktywnych, które zostały wpisane na listę środków niemających zastosowania medycznego i o silnym potencjale uzależniającym. Po latach w wielu krajach ponownie dopuszczono je do badań klinicznych. Wydaje się, że jednym z powodów może być występowanie lekooporności u pacjentów chorujących na depresję lub zespół stresu pourazowego oraz długi czas oczekiwania na odpowiedź terapeutyczną (4-8 tygodni), co jest niebezpieczne szczególnie dla osób z ciężkim rodzajem depresji. Prowadzi to do poszukiwania nowych, skutecznych metod o ograniczonych skutkach ubocznych, które występują u osób przyjmujących legalne farmaceutyki. Obecne metody badawcze, takie jak randomizacja, podwójne zaślepienie czy udział grupy kontrolnej, są źródłem dokładniejszych danych ze względu na ich niezależność od większej ilości czynników mogących mieć wpływ na wynik. Oprócz tego możliwe jest użycie nowoczesnych technik neuroobrazowania, aby dokładniej poznać mechanizmy działania badanych produktów leczniczych, nie tylko w kontekście subiektywnej oceny pacjenta, ale również obserwacji obszarów aktywności mózgu. Wraz z upływem czasu substancje psychoaktywne stają się obiektem zainteresowania coraz większej liczby naukowców. Wiele badań zawiera pozytywne doniesienia na temat ich działania, a sama opinia społeczna zdaje się zmieniać w kierunku nadziei na nowe, potencjalne leki szczególnie dla pacjentów wykazujących oporność na stosowane do tej pory środki.

\section{Charakterystyka wybranych substancji psychoaktywnych}

Psylocybina jest alkaloidem naturalnie występującym w grzybach z rodzaju Psilocybe. Określana niesłusznie mianem substancji halucynogennej prowadzi do zmian percepcji nieudających rzeczywistości. Przyjmowana jest doustnie w formie suszu z grzybów, a w układzie pokarmowym zostaje poddana działaniu fosfatazy alkalicznej i estaraz,

1 Uniwersytet Przyrodniczy w Lublinie, Wydział Nauk o Żywności i Biotechnologii, gutowskagabriela2020@gmail.com 
dzięki czemu powstaje jej metabolit - psylocyna. Obie mają budowę zbliżoną do serotoniny (5-HT) i łączą się z receptorami serotoninergicznymi, zwiększając jej stężenie $\mathrm{w}$ mózgu. Niektóre badania sugerują, że oddziałują również z receptorami dopaminowymi $\mathrm{D}_{1}$ oraz $\mathrm{D}_{3}$ [Gill $\mathrm{i}$ in. 2020]. Aktywacja receptorów $5 \mathrm{HT}_{2}$ jest skorelowana z pozytywnymi zmianami neuroplastycznymi w mózgu, co wywołuje przeciwdepresyjny i przeciwlękowy efekt u ludzi [Dydak i in. 2016].

3,4-metylenodioksyamfetamina (MDMA) jest syntetyczną cząsteczką zwaną potocznie ecstasy, której mechanizm działania jest zbliżony do leków przeciwdepresyjnych (SSRI) - inhibitorów wychwytu zwrotnego serotoniny. Po spożyciu przenika przez śluzówkę jelita, a następnie pokonuje barierę krew-mózg. Wykazuje duże powinowactwo do transportera serotoniny (SERT), prowadząc do zwiększenia jej stężenia w tkankach mózgu. MDMA charakteryzuje się również hamowaniem wychwytu innych monoamin - dopaminy i noradrenaliny - jednak w dużo mniejszym stopniu, a także prolaktyny, oksytocyny czy wazopresyny. Działania te skutkują tymczasową zmianą percepcji, zwiększeniem elastyczności poznawczej i emocji, a co za tym idzie dają lepsze możliwości terapeutyczne. Ponadto zauważono redukcję objętości ciała migdałowatego odpowiedzialnego za przechowywanie i przetwarzanie emocji [Varker i in. 2020, Gill i in. 2020].

Mechanizm działania LSD, czyli dietyloamidu kwasu D-lizergowego, opiera się na modulacji wielu szlaków neuronalnych, gdyż oddziałuje z receptorami serotoniny rozmieszczonymi w różnych obszarach mózgu. Cząsteczka substancji przez przyłączenie się do receptora (5-HTR) aktywuje uwolnienie neuroprzekaźnika z komórki neuronu, co powoduje mocne odczucie szczęścia. Psychodelik ten jest również substancją prowadzącą do wystąpienia halucynacji oraz omamów słuchowych i wzrokowych przez oddziaływanie z receptorem serotoniny 5-HT2A. LSD stymuluje wzrost dendrytów oraz tworzenie połączeń neuronalnych [Herian 2020].

\section{Czynniki wpływające na rozwój depresji i zespołu stresu pourazowego}

Niedobór neuroprzekaźników takich jak: serotonina, dopamina i noradrenalina jest czynnikiem wpływającym na występowanie zaburzeń depresyjnych. Spadek ich stężenia skutkuje zachowaniami kompulsywnymi, obsesją oraz lękiem. Mniejsza ilość dopaminy powoduje utratę motywacji oraz przyjemności czerpanej z działania. Z kolei mniejsza ilość noradrenaliny objawia się utratą czujności, energii, uwagi oraz zainteresowania życiem [Chiriţă $i$ in. 2015].

Astrocyty to komórki glejowe, które pełnią wiele funkcji w procesach związanych $\mathrm{z}$ inteligencją, są swoistymi strażnikami bariery krew-mózg, biorą udział w neuroprzekaźnictwie. Badania informują, że ich ilość u myszy wynosi $60 \%$, natomiast u ludzi stanowią nawet $90 \%$ wszystkich komórek nerwowych. Regresja astrocytów jest związana z zaburzeniami depresyjnymi, eksperymenty potwierdzają mniejszy ich udział w korze przedczołowej. Dodatkowo u osób dotkniętych tą chorobą zaobserwowano spadek ich gęstości i objętości odpowiednio w ciele migdałowatym oraz hipokampie [Cobb i in. 2016, Czéh i Nagy 2018].

Jednym z białek odpowiedzialnych za neurogenezę jest neurotroficzny czynnik pochodzenia mózgowego (ang. brain-derived neurotrophic factor - BDNF) skorelowany z zaburzeniami depresyjnymi. Odpowiada za neuroplastyczność i neuroprotekcję mózgu. U osób z trwającą chorobą wykazano trzykrotnie niższy jego poziom. Niskie stężenie 
BDNF stwierdza się również w dysfunkcjach psychicznych takich jak schizofrenia, choroba Alzheimera czy choroba afektywna dwubiegunowa, co podkreśla jego szerokie działanie. W modelu zwierzęcym wlew BDNF do mózgu przez okres 2 tygodni zwiększa neurogenezę w hipokampie, co skutkuje działaniem przeciwlękowym i przeciwdepresyjnym [Sen i in. 2008].

Cytokiny to markery stanu zapalnego, których liczba zwiększa się w przebiegu depresji, co sugeruje korelację obu stanów [Li i in. 2017]. Depresja może być skutkiem występowania chronicznego stresu - czynnika odpowiedzialnego za indukcję stanu zapalnego powstającego w wyniku przewlekłej aktywacji podwzgórze-przysadka-nadnercza (HPA). Prowadzi to do uwalniania glukokortykoidów do krwiobiegu [Chiriţă i in. 2015]. Szczególnie ciężka depresja charakteryzuje się stałą nadaktywnością osi HPA i rozregulowaniem autonomicznego układu nerwowego (ANS) [Grippo i Johnson 2009].

Zespół stresu pourazowego (ang. posttraumatic stress disorder - PTSD) jest to przewlekłe zaburzenie psychiatryczne, które często występuje w wyniku narażenia na poważne stresory, takie jak śmierć bliskiej osoby, katastrofy wojenne, otrzymanie diagnozy choroby zagrażającej życiu czy traumatyczne sytuacje po zażyciu substancji psychoaktywnych [Miao i in. 2018]. PTSD to jednostka chorobowa, którą charakteryzują: koszmary senne, przeżywanie na nowo traumatycznych zdarzeń, pesymistyczne myśli o sobie i innych, stronienie od bodźców związanych z traumą, nadmierna czujność oraz pobudzenie i reaktywność, bezsenność lub agresja, które są związane z traumą. Fizjologicznie łączność pomiędzy hipokampem, korą przedczołową, a ciałem migdałowatym zapewnia kontrolę strachu oraz adekwatne odpowiedzi na emocje. W PTSD ciało migdałowate jest nadaktywne, przez co reakcje są wzmożone i niekompatybilne [Hutchison i Bressi 2020]. Ostatnie badania sugerują, że w fenomenologię PTSD jest zaangażowany układ neuroendokrynny oraz immunologiczny [Newport i Nemeroff 2000, Miao i in. 2018]. Po zadziałaniu bodźca środowiskowego aktywacji w wyniku stresu ulega oś podwzgórze-przysadka-nadnercza (HPA), a także współczulny układ nerwowy, to sprawia, że uwalniane są katecholaminy oraz glukokortykoidy (GC). GC łącząc się z receptorem glukokortykoidowym (GR), hamują ujemne sprzężenie zwrotne osi HPA, co skutkuje zaburzeniami neuroendokrynnymi. Co więcej GC wpływają na wzmocnienie metabolizmu oraz immunosupresję. U osób chorych na PTSD obserwuje się zwiększony stan zapalny wywołany wysokim stężeniem cytokin takich jak: czynnik martwicy nowotworów $\alpha$ (TNF- $\alpha$ ), interleukiny-6 (IL-6) interleukiny-1 $\beta$ (IL-1 $\beta$ ) w porównaniu z osobami zdrowymi. Badanie ujawniło także, że osoby z PTSD wykazują niższą integralność istoty białej w mózgu [Miao i in. 2018]. Ponadto cierpiący na PTSD mają mniejsze objętości hipokampu w zestawieniu z osobami zdrowymi, co może być przyczyną tej choroby [Logue i in. 2018].

\section{Zastosowanie substancji psychoaktywnych w leczeniu zaburzeń psychicznych}

Czynnikiem branym pod uwagę podczas rozważań leczenia depresji za pomocą MDMA jest wpływ empatogenu na układ serotoninergiczny w oparciu o teorię monoaminową. Pewne randomizowane badanie $\mathrm{z}$ grupą kontrolną oceniło wpływ regularnego zażywania MDMA na pacjentów. $23 \%$ z nich wykazywało objawy depresji potwierdzone kwestionariuszem CES-D i K10, co może sugerować negatywne działanie badanej sub- 
stancji na stan układu nerwowego. Inny eksperyment wykazał natomiast przeciwdepresyjne działanie 3,4-metylenodioksyamfetaminy poprzez zredukowanie zaburzeń choroby w porównaniu z grupą kontrolną [Gill i in. 2020]. W badaniu Kuypers i in. [2018] opisano efekt podania dwóch dawek MDMA, z siedmiodniową przerwą, pacjentom wykazującym depresyjne zaburzenia nastroju w podziale na grupy posiadające krótkie (s) lub długie (1) allele genu kodującego transporter serotoniny. Fizjologicznie osoby będące homozygotami ss lub heterozygotami wykazują większą podatność na zachorowanie. Wyniki wykazały, że kobiety posiadające dwa allele 1 odczuwały znaczące zmniejszenie objawów choroby w porównaniu z grupą kontrolną oraz mężczyznami.

Psychodeliki: LSD i psylocybina mają podobny profil farmakodynamiczny oraz wywierają prawie identyczne stany psychodeliczne u pacjentów, jednak farmakokinetyka alkaloidu pochodzącego z grzybów jest bardziej użyteczna ze względu na krótszy czas trwania doznań.

Pierwsze badanie efektu terapeutycznego psylocybiny na zaburzenia depresyjne i lękowe miało miejsce w 2011 r. na grupie pacjentów chorujących na raka. Po podaniu średniej dawki $0,2 \mathrm{mg} / \mathrm{kg}$ masy ciała badanego produktu leczniczego dwunastu osobom (do badania grupy kontrolnej została użyta niacyna) odnotowano stałą poprawę stanu zdrowia psychicznego na przestrzeni 6 miesięcy. W kolejnych dwóch badaniach klinicznych przeprowadzonych w 2016 r. również otrzymano pozytywne wyniki. W pierwszym z nich porównano wpływ bardzo niskich i bardzo wysokich dawek psylocybiny $(0,01-$ $0,004 \mathrm{mg} / \mathrm{kg}$ i $0,31-0,43 \mathrm{mg} / \mathrm{kg}$ ). W grupie otrzymującej większą ilość produktu badanego zaobserwowano zredukowanie objawów zaburzeń depresyjno-lękowych, podczas gdy $60 \%$ z nich zgłosiło całkowite ustąpienie dolegliwości. W drugim eksperymencie uzyskano remisję choroby u $60 \%$ pacjentów, badając zaburzenia adaptacyjne i ogólne zaburzenia lękowe. W obu badaniach osobami zakwalifikowanymi byli pacjenci onkologiczni [Greif i Šurkala 2020].

W przypadku LSD pierwsze badania dotyczyły jego wpływu na uzależnienie od alkoholu i występowanie psychoz. Obecnie coraz więcej badań opisuje terapeutyczne działanie u pacjentów cierpiących na PTSD czy zaburzenia depresyjne, a wiele wciąż trwa [Meikle i in. 2020, Galvão-Coelho i in. 2021]. Jednym z bardziej przełomowych badań był podwójnie zaślepiony, randomizowany, kontrolowany placebo eksperyment, do którego zakwalifikowano 12 pacjentów, z czego u połowy stwierdzono zespół lęku uogólnionego, a reszta wykazywała objawy typowe dla zaburzeń lękowych powiązane z chorobą zagrażającą życiu. Grupie eksperymentalnej podano $200 \mu \mathrm{g}$ badanego produktu leczniczego, natomiast grupa kontrolna otrzymała aktywne placebo w dawce $20 \mu \mathrm{g}$ LSD podczas jednej na dwie sesje. Uzyskane wyniki potwierdziły redukcję stanów lękowych po dwóch sesjach wspomaganych dietyloamidem kwasu D-lizergowego [Gasser i in. 2014].

Do badania przeprowadzanego w $2011 \mathrm{r}$. w celu ustanowienia wpływu MDMA, w połączeniu z psychoterapią, na objawy PTSD zakwalifikowano 20 pacjentów. Badanie było prowadzone z podwójnie ślepą próbą, randomizowane z procesem cross-over i grupą kontrolną otrzymującą placebo. Po odbyciu sesji pacjenci z grupy otrzymującej produkt badany zgłaszali poprawę reakcji fizycznej na stres w porównaniu z grupą placebo, a 12 pacjentów (10 z grupy badanej, 2 z grupy kontrolnej) nie wykazywało kwalifikowalności do rozpoznania PTSD według skali CAPS-IV (ang. The Clinically Administered PTSD Scale). Następnie w 2018 r. ci sami badacze rozszerzyli eksperyment obejmujący wetera- 
nów wojennych, strażaków oraz policjantów ze stwierdzonym zespołem stresu pourazowego. Grupa placebo otrzymywała MDMA w dawce $30 \mathrm{mg}$, osoby zakwalifikowane do grupy badanej odpowiednio $75 \mathrm{mg}$ oraz $125 \mathrm{mg}$ podczas dwóch sesji terapeutycznych mających miejsce w odstępie ok. 30 dni. Spośród 24 pacjentów poddanych 12-miesięcznej obserwacji u 67\% nie zdiagnozowano PTSD [Varker i in. 2020]. MDMA wykazuje duży potencjał terapeutyczny w leczeniu zespołu stresu pourazowego i według niektórych badań może być potencjalnie wprowadzona na rynek amerykański w latach 2021/2022 [Greif i Šurkala 2020].

Psylocybina oraz LSD mają właściwości, które mogące przyczynić się do remisji PTSD, lecz brakuje odpowiednich badań obejmujących ten zakres zastosowań.

\section{Podsumowanie}

Zarówno depresja, jak i PTSD to choroby przewlekłe, które wpływają na jednostkę pod względem psychicznym oraz fizycznym. Skutki tych schorzeń utrudniają codzienne funkcjonowanie w społeczeństwie i wpływają destrukcyjnie na chorych. Zmieniają postrzeganie rzeczywistości. W przypadku PTSD zniekształceniu ulega obraz siebie, chory nieustannie wspomina traumatyczne zdarzenia, ma pesymistyczne myśli, stroni od bodźców związanych z traumą oraz jest nadmiernie czujny. Depresja z kolei objawia się: niską samooceną, upośledzeniem funkcji poznawczych i regulacji emocjonalnej, brakiem energii i bólem bez wyraźnej przyczyny. Tradycyjna farmakoterapia nie zawsze spełnia swoją funkcję, dlatego użycie substancji psychodelicznych może zakończyć się w tych przypadkach sukcesem. Szczególne znaczenie mają psylocybina, LSD oraz MDMA, jednak badania, które obecnie zostały zrealizowane, wymagają powtórzenia na większej grupie badawczej. Pomimo tego przeprowadzone eksperymenty, szczególnie te, które informują o złagodzeniu objawów związanych z lękiem, stresem oraz całkowitym ustąpieniem objawów, dają nadzieję chorym.

\section{Bibliografia}

Chiriţă A.L., Gheorman V., Bondari D., Rogoveanu I., 2015. Current understanding of the neurobiology of dajor depressive disorder. Rom. J. Morphol. Embryol. 56(2), 651-658.

Cobb J.A., O’Neill K., Milner J., Mahajana G.J., Lawrence T.J., Warren L.M., Miguel-Hidalgo J., Rajkowska G., Stockmeier C.A., 2016. Density of GFAP-immunoreactive astrocytes is decreased in left hippocampi in major depressive disorder. Neuroscience 316, 209-220. https://doi.org/10.1016/j.neuroscience.2015.12.044

Czéh B, Nagy S.A., 2018. Clinical findings documenting cellular and molecular abnormalities of glia in depressive disorders. Front. Mol. Neurosci. 27, 11-56. https://doi.org/10.3389/fnmol.2018.00056

Drevets W.C., Savitz J., Trimble M., 2008. The subgenual anterior cingulate cortex in mood disorders. C.N.S. Spectr. 13(8), 663-681. https://doi.org/10.1017/S1092852900013754

Dydak K., Śliwińska-Mossoń M., Milnerowicz H., 2016. Psylocybina jako alternatywny lek dla osób cierpiacych na depresję. Psychiatr. Psychol. Klin. 3(16), 165-170. https://doi.org/10.15557/PiPK.2016.0023

Galvão-Coelho N.L., Marx W., Gonzalez M., Sinclair J., de Manincor M., Perkins D., Sarris J., 2021. Classic serotonergic psychedelics for mood and depressive symptoms: a meta-analysis 
of mood disorder patients and healthy participants. Psychopharmacology 238(2), 341-354. https://doi.org/10.1007/s00213-020-05719-1

Gasser P., Holstein D., Michel Y., Doblin R., Yazar-Klosinski B., Passie T., Brenneisen R., 2014. Safety and efficacy of lysergic acid diethylamide-assisted psychotherapy for anxiety associated with life-threatening diseases. J. Nerv. Ment. Dis. 202(7), 513-520. https://doi.org/10.1097/NMD.0000000000000113

Gill H., Gill B., Chen-Li D., El-Halabi S., Rodrigues N. B., Cha D. S., Lipsitz O., Lee Y., Rosenblat J.D., Majeed A., Mansur R.B., Nasri F., Ho R., McIntyre R.S., 2020. The emerging role of psilocybin and MDMA in the treatment of mental illness. Expert. Rev. Neurother. 20(12), 1263-1273. https://doi.org/10.1080/14737175.2020.1826931

Greif A., Šurkala M., 2020. Compassionate use of psychedelics. Med. Health Care Philos. 23(3), 485-496. https://doi.org/10.1007/s11019-020-09958-z

Grippo A.J., Johnson A.K., 2009. Stress, depression, and cardiovascular dysregulation: a review of neurobiological mechanisms and the integration of research from preclinical disease models. Stress. 12(1), 1-21. https://doi.org/10.1080/10253890802046281

Herian M., 2020. Nie takie halucynogeny straszne, jak je malują. Wszechświat 121(4-6), 137-148.

Hutchison C.A., Bressi S.K., 2020. MDMA-assisted psychotherapy for posttraumatic stress disorder: implications for social work practice and research. Clin. Soc. Work J. 48(4), 421-430. https://doi.org/10.1007/s10615-018-0676-3

Kuypers K.P., De La Torre R., Farré M., Xicota L., Perna E.D.S.F., Theunissen E.L., Ramaekers J.G., 2018. Depressive mood ratings are reduced by MDMA in female polydrug ecstasy users homozygous for the 1-allele of the serotonin transporter. Sci. Rep. 8(1), 1-7. https://doi.org/10.1038/s41598-018-19618-1

Li M., Kouzmina E., McCusker M., Rodin D., Boutros P.C., Paige C.J., Rodin G., 2017. Cytokines and depression in cancer patients and caregivers. Neuropsychiatr. Dis. Treat. 13, 2903-2911. https://doi.org/10.2147/NDT.S144774

Logue M.W., van Rooij S.J., Dennis E.L., Davis S.L., Hayes J.P., Stevens J.S., Densmore M., Haswell C.C., Ipser J., Koch S.B.J., Korgaonkar M., Lebois L.A.M., Peverill M., Baker J.T., Boedhoe P.S.W., Frijling J.L., Gruber S.A., Harpaz-Rotem I., Jahanshad N., Koopowitz S., Levy I., Nawijn L., O'Connor L., Olff M., Salat D.H., Sheridan M.A., Spielberg J.M., van Zuiden M., Winternitz S.R., Wolff J.D., Wolf E.J., Wang X., Wrocklage K., Abdallah C.G., Bryant R.A., Geuze E., Jovanovic T., Kaufman M.L., King A.P., Krystal J.H., Lagopoulos J., Bennett M., Lanius R., Liberzon I., McGlinchey R.E., McLaughlin K.A., Milberg W.P., Miller M.W., Ressler K.J., Veltman D.J., Stein D.J., Thomaes K., Thompson P.M., Morey R.A., 2016. Smaller hippocampal volume in posttraumatic stress disorder: a multisite ENIGMA-PGC study: subcortical volumetry results from posttraumatic stress disorder consortia. Biol. Psychiatry 83(3), 244-253. https://doi.org/10.1016/j.biopsych.2017.09.006

Meikle S.E., Liknaitzky P., Rossell S.L., Ross M., Strauss N., Thomas N., Murray G., Williams M., Castle D.J., 2020. Psilocybin-assisted therapy for depression: how do we advance the field? Aust. N.Z.J. Psychiatry 54(3), 225-231. https://doi.org/10.1177/0004867419888575

Miao X.R., Chen Q.B., Wei K., Tao K.M., Lu Z.J., 2018. Posttraumatic stress disorder: from diagnosis to prevention. Mil. Med. Res. 5(1), 1-7. https://doi.org/10.1186/s40779-018-0179-0

Newport D.J., Charles B.N., 2000. Neurobiology of posttraumatic stress disorder. Curr. Opin. Neurobiol. 10(2), 211-218. https://doi.org/10.1016/S0959-4388(00)00080-5

Sen S., Duman R., Sanacora G., 2008. Serum BDNF, depression and anti-depressant medications: meta-analyses and implications. Biol. Psychiatry 64(6), 527-532. https://doi.org/10.1016/j.biopsych.2008.05.005

Krishnan V., Nestler E.J., 2008. The molecular neurobiology of depression. Nature 455(7215), 894-902. https://doi.org/10.1038/nature07455

Varker T., Watson L., Gibson K., Forbes D., O’Donnell M.L., 2020. Efficacy of psychoactive drugs for the treatment of posttraumatic stress disorder: a systematic review of MDMA, ketamine, LSD and psilocybin. J. Psychoactive Drugs 53(1), 85-95. https://doi.org/10.1080/02791072.2020.1817639 


\section{Nawyki żywieniowe pacjentów bariatrycznych oraz rola żywienia w chirurgicznym leczeniu otyłości}

Eating habits in bariatric surgery patients and the role of nutrition in surgical treatment of obesity

Jedynym rekomendowanym sposobem leczenia pacjentów z otyłością olbrzymią jest interwencja chirurgiczna. Nie można jej zastąpić postępowaniem zachowawczym, które zwiększa ryzyko zgonu [Wyleżoł i in. 2009, Kuczyńska i in. 2012]. Nieprawidłowy sposób odżywiania dotyczy większości osób kwalifikowanych do zabiegu zmniejszającego pojemność żołądka [Szczepańska i Brończyk-Puzoń 2014]. Osoby poddane zabiegowi powinny zostać otoczone opieką interdyscyplinarnego zespołu, w skład którego wchodzi także dietetyk, odpowiadający za edukację żywieniową pacjenta. Celem niniejszej pracy jest ocena sposobu żywienia mężczyzny z otyłością trzeciego stopnia, poddanego operacji bariatrycznej oraz opracowanie projektu diety na późny okres pooperacyjny.

\section{Material i metody}

Analizę przypadku przeprowadzono na 41-letnim mężczyźnie z otyłością III $^{\circ}$ oraz współistniejącymi schorzeniami, do których należały: nadciśnienie tętnicze, dna moczanowa, dyslipidemia, stłuszczenie wątroby, bóle stawów kolanowych. BMI pacjenta przed rozpoczęciem przygotowań do operacji wynosiło $45,4 \mathrm{~kg} / \mathrm{m}^{2}$. Mężczyzna pracował jako kierowca i prowadził siedzący tryb życia, co wspólnie z nadmierną podażą pokarmu doprowadziło do rozwinięcia się u niego zaawansowanej otyłości. Pacjent wymagał leczenia farmakologicznego i przyjmował następujące leki: Vanatex HCT $160 \mathrm{mg}$, Nebilet $5 \mathrm{mg}$, Accard $75 \mathrm{mg}$, Lipitor $40 \mathrm{mg}$, Allupol $100 \mathrm{mg}$ przeciwko nadciśnieniu tętniczemu, dyslipidemii oraz dnie moczanowej. Mężczyzna został zakwalifikowany do zabiegu, a następnie poddany operacji bariatrycznej - rękawowej resekcji żołądka (ang. sleeve gastrectomy). Ocenę sposobu żywienia wykonano na podstawie 7-dniowego dziennika żywieniowego pacjenta z okresu sprzed operacji. Stanowił on zapis spożywanych posiłków i wypijanych napojów wraz ze wskazaniem pór przyjmowania pokarmów. Ocena obejmowała bilans diety przy wykorzystaniu kalkulatora dietetycznego - programu Aliant. Uzyskane wyniki zinterpretowano, kierując się aktualnymi Normami Żywienia dla Populacji Polski [Jarosz i in. 2020]. Drugi element ewaluacji stanowiła jakościowa ocena ja-

\footnotetext{
${ }^{1}$ Uniwersytet Rolniczy im. Hugona Kołłątaja w Krakowie, Wydział Technologii Żywności, karolina.lanoszka@student.urk.edu.pl
} 
dłospisu przy zastosowaniu metody punktowej według Starzyńskiej oraz według Bielińskiej z modyfikacją Kuleszy. Obie ww. metody dostarczają informacji o rodzaju i częstotliwości spożywania produktów żywnościowych, a także o długości przerw pomiędzy posiłkami [Ciborowska i Rudnicka 2014]. Projekt diety sporządzono w oparciu o piramidę żywienia dla pacjentów bariatrycznych. Plan żywieniowy obejmował rozpiskę tygodniowego jadłospisu, w którym dokonano bilansu energii i podstawowych składników odżywczych (tj. białek, tłuszczów, węglowodanów ogółem oraz przyswajalnych, błonnika), a także następujących składników mineralnych i witamin: wapnia, żelaza, witaminy A, D, $\mathrm{B}_{1}, \mathrm{~B}_{12}$, folianów. Ponadto, kontrolowano spożycie cholesterolu oraz kwasów thuszczowych - trans, nasyconych (SFA - ang. saturated fatty acids) i nienasyconych, zarówno jednonienasyconych (MUFA - ang. monounsaturated fatty acids), jak i wielonienasyconych (PUFA - ang. poliunsaturated fatty acids), z rozróżnieniem na kwasy z rodziny $n-3$ oraz $n-6$. Oceny sporządzonego planu żywieniowego dokonano poprzez porównanie wartości z podsumowania bilansu diety z założeniami Norm Żywienia dla Populacji Polski [Jarosz i in. 2020].

\section{Wyniki}

Przeanalizowanie dziennika żywieniowego pacjenta, przez dokonanie bilansu energii oraz wybranych składników pokarmowych, a także wykonanie oceny jadłospisu metodą według Starzyńskiej i według Bielińskiej z modyfikacją Kuleszy umożliwiło ocenę sposobu żywienia mężczyzny w okresie poprzedzającym wykonanie u niego zabiegu zmniejszenia żołądka. Punktowa ocena jadłospisu pozwoliła na postawienie konkluzji, że sposób żywienia pacjenta przed operacją i dokonaniem zmiany stylu życia był nieprawidłowy. Suma punktów uzyskana w teście Starzyńskiej wyniosła zaledwie 7 na 30 możliwych, w związku z czym jadłospis oceniono jako „zły (nienadający się do naprawienia)”. Nauka prawidłowych nawyków żywieniowych oraz ich wdrażanie jest niezwykle istotną kwestią w przypadku pacjenta zakwalifikowanego do zabiegu bariatrycznego.

Badania oceny sposobu żywienia prowadzone pośród pacjentów bariatrycznych wykazują, iż sposób odżywiania osób z otyłością olbrzymią jest przeważnie nieprawidłowy [Szczepańska i Brończyk-Puzoń 2014]. U pacjenta, którego przypadek analizowano w niniejszej pracy, także zaobserwowano ten problem. Mężczyzna spożywał zazwyczaj zalecaną ilość posiłków (4-5 dziennie). Niestety jeden z nich stanowiła zwykle słodka przekąska, np. batonik, który mężczyzna mógł łatwo spożyć podczas krótkiej przerwy w pracy. Pacjent zmagał się z problemem podjadania. Ustalono, że jako przekąski wybierał zazwyczaj czekoladowe batoniki z nadzieniem (w dni pracujące) oraz ciasta (w dni wolne, jako element weekendowego obiadu). Test Starzyńskiej umożliwia analizę poprawności skomponowania jadłospisu i ocenia go pod kątem: ilości posiłków, częstotliwości uwzględniania w posiłkach produktów będących źródłem białka zwierzęcego oraz produktów takich jak: mleko lub sery, warzywa i owoce (ogólnie oraz w postaci surowej), pieczywo razowe, kasze, suche nasiona roślin strączkowych. Na podstawie oceny jadłospisu przy wykorzystaniu testu Starzyńskiej zaobserwowano, że:

- ilość posiłków zawierających produkty dostarczające białka zwierzęcego nie była wystarczająca. Wyrażona procentowo wynosiła $67 \%$, a więc mniej niż $75 \%$, co zgodnie 
z kryteriami ww. testu jest uznane za dolną granicę umożliwiającą uzyskanie 2 punktów (na 5 możliwych),

- pacjent spożywał mleko lub sery niewystarczająco często (produkty należące do tej grupy były przez niego dostarczane w tygodniu z 1-3 posiłkami dziennie, co pozwoliło na przyznanie jadłospisowi 2 punktów),

- podaż warzyw i owoców z dietą była niewystarczająca. Produkty te występowały w jadłospisie ,rzadziej niż codziennie w co najmniej w 2 posiłkach”, co skutkowało przyznaniem 0 punktów w tej części testu. Ponadto w postaci surowej były dostarczane jedynie w 71\% dni (a więc rzadziej niż w 75\% dni, przy której to częstotliwości jadłospis może uzyskać 2 punkty),

- nieprawidłowa podaż dotyczyła także produktów, których spożywanie stoi u podstaw prawidłowej diety. Mowa tu o pieczywie razowym, kaszach i suchych nasionach roślin strączkowych, które były spożywane przez pacjenta „,rzadziej niż w 75\% dni”, a dokładnie w zaledwie $14 \%$ dni prowadzenia zapisu żywieniowego.

Ocena sposobu żywienia pacjenta z wykorzystaniem testu Bielińskiej z modyfikacją Kuleszy umożliwia dokonanie analizy składu spożytych posiłków. Zgodnie z kryteriami ww. testu mogą być one złożone z węglowodanów lub węglowodanów i tłuszczów, stanowiących podstawowy element posiłku oraz zawierać dodatek w postaci: produktów będących źródłem białka zwierzęcego, mleka lub przetworów mlecznych, warzyw i owoców. Test wyróżnia 9 możliwych konfiguracji posiłków, do których następnie dopasowuje się dania/produkty spożywcze spożyte przez pacjenta. Za pełnowartościowe uznaje się te posiłki, które zawierają następujące komponenty: węglowodany lub węglowodany i tłuszcze oraz produkty będące źródłem białka zwierzęcego/mleko lub produkty mleczne (bądź obydwa warianty jednocześnie) oraz dodatek w postaci warzyw lub owoców. Na podstawie testu Bielińskiej z modyfikacją Kuleszy oceniono, że pacjent zwykle komponował swoje pierwsze śniadania w prawidłowy sposób. Za pełnowartościowy posiłek uznano aż $57 \%$ z nich. Jako produkty stanowiące dodatek wybierał zwykle artykuły spożywcze będące źródłem białka zwierzęcego oraz mleko lub produkty mleczne (43\% spożytych śniadań) lub produkty będące źródłem białka zwierzęcego oraz warzywa lub owoce (43\% spożytych śniadań). Drugie śniadania były przygotowywane przez pacjenta w domu, a następnie spożywane w pracy. Były one posiłkami niepełnowartościowymi, głównie z powodu nieuwzględniania dodatku warzyw lub owoców. Jak wspomniano wcześniej, produkty należące do tej grupy były przez pacjenta spożywane w niewystarczającej ilości i nie stanowiły podstawy jego diety. Niedostateczną podaż warzyw i owoców w diecie pacjenta wykryto przy użyciu obu zastosowanych testów. 72\% obiadów bądź obiadokolacji spożytych przez pacjenta stanowiły posiłki pełnowartościowe.

Analiza dziennika żywieniowego pacjenta pozwoliła na zaobserwowanie problemu polegającego na spożywaniu głównego posiłku dnia, najbardziej obfitego pod względem kaloryczności i objętości, dopiero po zakończeniu pracy, wieczorem ok. 19.00-20.00. Pomijanie pory obiadowej wiązało się dodatkowo z nasilaniem problemu podjadania (spożywanie słodkich przekąsek, aby zaspokoić głód i dostarczyć energię) oraz pomijaniem kolacji, wypieranej poprzez spożywanie późnego obiadu (obiadokolacji). Tego typu błędy obserwowano w dni pracujące, kiedy to pacjent dostosowywał swój harmonogram spożywania posiłków do godzin pracy. W związku z powyższym kolejnym rozpoznanym błędem żywieniowym była nieprawidłowa długość przerw pomiędzy posiłkami. Wyno- 
siła ona od 4 do 5 godzin, a więc nie wpasowywała się w zalecany przedział $3-4$ godzinnego odstępu. W analizie dziennika żywieniowego zwracano także uwagę na dobór produktów wybieranych przez pacjenta przy komponowaniu i sporządzaniu posiłków. Problem z doborem wartościowych produktów spożywczych, całkowite unikanie pewnych grup produktów czy sięganie po żywność typu fast food to jedne z najczęstszych błędów żywieniowych popełnianych przez pacjentów z otyłością znacznego stopnia, kwalifikowanych do zabiegu bariatrycznego [Szczepańska i Brończyk-Puzoń 2014]. Podobne nieprawidłowości zauważono u mężczyzny, którego przypadek analizowano na potrzeby badania. Jak wspomniano wcześniej, pacjent spożywał niewystarczające ilości warzyw i owoców, które znajdują się u podstawy „Piramidy zdrowego żywienia i aktywności fizycznej”, i zgodnie z zaleceniami powinny być spożywane w jak największej ilości, stanowiąc przynajmniej połowę tego, co jemy. Na podstawie dziennika żywieniowego stwierdzono, że mężczyzna spożywał warzywa codziennie, natomiast owoce wcale nie występowały w notatkach $\mathrm{z}$ tygodnia prowadzenia zapisu. Pacjent nie stosował się do zasady, zgodnie z którą ww. grupy produktów powinny stanowić podstawę diety. Spożywał je raczej jako niewielki dodatek do śniadania, tylko czasem jako główną część posiłku. Zasada racjonalnego żywienia, zgodnie z którą zdrowa dieta oparta jest na uwzględnianiu w jadłospisie pełnoziarnistych produktów zbożowych, także nie znalazła zastosowania w diecie pacjenta. Produkty takie jak pełnoziarniste, razowe pieczywo, grube kasze nie występowały w menu mężczyzny. Zamiast tego wybierał jasne pieczywo (chleb i bułki), a jako dodatek do dań głównych - ziemniaki, bądź makaron (do zup). Dieta mężczyzny była uboga w nabiał. Pomimo tego, że pacjent sięgał po mleko, stanowiło ono jedynie dodatek do kawy. Przetwory mleczne, takie jak jogurt naturalny, kefir, twaróg, pojawiały się w jadłospisie mężczyzny jedynie sporadycznie. Zamiast zdrowych odpowiedników o niewielkiej zawartości tłuszczu, wybierane były tłuste sery podpuszczkowe, które pacjent spożywał dużo chętniej i częściej. Najchętniej stosowane przetwory mięsne stanowiły wyroby wysoko przetworzone (konserwy, parówki) i thuste (kiełbasa, boczek). Jako mięsne dania obiadowe pacjent preferował potrawy smażone, takie jak np. kotlet mielony lub kotlet schabowy w panierce. Niezwykle istotnym elementem diety są wypijane płyny - zgodnie z regułami zdrowego żywienia najlepiej aby stałym nawykiem było picie wody, bez substancji dosładzających.

W analizowanym przypadku błędem pacjenta było regularne picie słodkich napojów gazowanych (typu coca-cola). Wypijane niemalże codziennie przyczyniały się do zwiększania podaży cukrów łatwo przyswajalnych. Pacjent przed zabiegiem i zmianą nawyków żywieniowych stosował dietę bogatoenergetyczną i wysokotłuszczową. Na podstawie wykonanego bilansu diety zauważono, że dostarczana ilość energii (średnio ponad $3000 \mathrm{kcal}$ dziennie) przekraczała wyliczone zapotrzebowanie energetyczne aż o 24 punkty procentowe. Nadwyżka pochodziła głównie z nadmiernej zawartości tłuszczów w diecie (\% realizacji założeń wyniósł aż 166\%). Spożywany pokarm obfitował w nasycone kwasy thuszczowe (SFA) oraz cholesterol. Na podstawie bilansu stwierdzono także nieprawidłowy stosunek kwasów tłuszczowych. Spożycie jednonienasyconych (MUFA) oraz wielonienasyconych kwasów tłuszczowych (PUFA) było zbyt niskie w porównaniu z podażą SFA. Nadmierną podaż zaobserwowano także dla następujących składników odżywczych: węglowodanów, żelaza, witaminy $\mathrm{A}, \mathrm{B}_{1}, \mathrm{~B}_{12}$. Natomiast, deficytowe spożycie dotyczyło witaminy D i folianów oraz wapnia. Pacjent nie dostarczył 
należytej ilości ww. składników na skutek nieprawidłowego komponowania diety i unikania/niewystarczającego spożycia produktów takich jak: mleko i przetwory mleczne, warzywa (w szczególności zielone warzywa liściaste), tłuste ryby morskie. Wysoka zawartość żelaza, witaminy $\mathrm{A}, \mathrm{B}_{1}, \mathrm{~B}_{12}$ była zapewne spowodowana częstym spożywaniem produktów pochodzenia zwierzęcego, w tym wędlin, mięsa, masła oraz margaryny (wzbogacanej witaminą A). Podsumowanie tygodniowego spożycia składników pokarmowych przedstawiono w tabeli 1 .

Tabela 1. Dziennik żywieniowy-bilans składników

\begin{tabular}{|l|c|c|c|}
\hline & $\begin{array}{c}\text { Średnia } \\
(7 \text { dni) }\end{array}$ & Założenia & $\begin{array}{c}\text { Realizacja } \\
\text { założeń (\%) }\end{array}$ \\
\hline Energia (kcal) & 3111,1 & 2500 & $124 \%$ \\
Białko (g) & 125,3 & 125 & $100 \%$ \\
Tłuszcz (g) & 137,8 & 83 & $166 \%$ \\
Węglowodany ogółem (g) & 350,3 & 313 & $112 \%$ \\
Węglowodany przyswajalne (g) & 331,7 & 288 & $115 \%$ \\
Błonnik (g) & 18,6 & 25 & $74 \%$ \\
SFA (g) & 53,7 & 19,4 & $277 \%$ \\
MUFA (g) & 52,4 & 41,5 & $126 \%$ \\
n-3 (g) & 3,9 & & \\
n-6 (g) & 15,9 & & \\
PUFA (g) & 19,8 & 22,1 & $90 \%$ \\
Cholesterol $(\mathrm{g})$ & 536,6 & 300 & $179 \%$ \\
Kw. tt. trans $(\mathrm{g})$ & 0,3 & & \\
Wapń $(\mathrm{mg})$ & 698,5 & 1000 & $70 \%$ \\
Żelazo $(\mathrm{mg})$ & 14,8 & 10 & $148 \%$ \\
Wit. A ( $\mu \mathrm{g})$ & 1236,7 & 900 & $137 \%$ \\
Wit. D $(\mu \mathrm{g})$ & 4,2 & 15 & $28 \%$ \\
Wit. B1 $(\mathrm{mg})$ & 2,0 & 1,3 & $157 \%$ \\
Foliany $(\mu \mathrm{g})$ & 298,6 & 400 & $75 \%$ \\
Wit. B12 $(\mu \mathrm{g})$ & 5,0 & 2,4 & $208 \%$ \\
\hline
\end{tabular}

Złe nawyki żywieniowe, nadmierna podaż energii, nieprawidłowy dobór produktów spożywczych oraz prowadzenie siedzącego trybu życia doprowadziły pacjenta do rozwoju otyłości (BMI 45,4 kg/m², masa ciała przed podjęciem leczenia - $157 \mathrm{~kg}$ ) i chorób dietozależnych. Problemy zdrowotne zaobserwowane u mężczyzny dowodzą, że brak troski o zdrowy styl życia, wyrażający się zaniechaniem uprawiania aktywności fizycznej oraz unikaniem zdrowego odżywiania, może po latach trwania w złych nawykach prowadzić do przybierania na masie ciała i do rozwoju różnego rodzaju schorzeń. Zjawiskiem często obserwowanym u pacjentów bariatrycznych jest stosowanie samodzielnych prób odchudzania przy wykorzystaniu różnego rodzaju diet redukcyjnych. Niestety dążenie do redukcji masy ciała bez konsultacji z dietetykiem kończy się często wystąpieniem efektu ,jo-jo" oraz zniechęceniem pacjenta, który reaguje negatywnie na surowe restrykcje i 
brak zadowalających efektów. Mężczyzna, podobnie jak część osób objętych badaniem prowadzonym przez Świerzko-Kludzikowską [2017], przed operacją i wizytą w gabinecie dietetyka podejmował próbę obniżenia masy ciała, stosując dietę Cambridge, opartą na specjalnych, sproszkowanych produktach. W założeniu dostarcza ona około $500 \mathrm{kcal}$ energii dziennie.

Pacjent zakwalifikowany do zabiegu bariatrycznego był do niego przygotowywany we współpracy z dietetykiem. Dzięki zastosowaniu diety ubogoenergetycznej osiągnął oczekiwane rezultaty, a więc konieczną przed zabiegiem, wstępną redukcję masy ciała. Następnie został poddany zabiegowi chirurgicznemu. Po operacji stosował dietę zgodną ze schematem postepowania żywieniowego dla osób poddanych operacji bariatrycznej, opracowanym przez University of Nevada School of Medicine [Jastrzębska i Ostrowska 2010]. Po zakończeniu okresu ścisłych restrykcji (6-8 tygodni od zabiegu), zastosowano dietę ubogoenergetyczną (1400 kcal), opartą o piramidę żywienia dla pacjentów bariatrycznych. Zaproponowany tygodniowy projekt diety uwzględniał bilans składników kontrolowanych przy dokonywaniu oceny sposobu żywienia pacjenta. Bilans planu żywieniowego sporządzonego dla pacjenta przedstawia tabela 2. Wybór składników pokarmowych uwzględnionych w bilansie był podyktowany dwoma elementami: schorzeniami występującymi u pacjenta oraz chęcią kontrolowania podaży tych składników, na których niedobory może być narażony po zabiegu bariatrycznym typu restrykcyjnego.

Tabela 2. Projekt diety - bilans składników

\begin{tabular}{|l|c|c|c|}
\hline & $\begin{array}{c}\text { Średnia } \\
(7 \text { dni) }\end{array}$ & Założenia & $\begin{array}{c}\text { Realizacja } \\
\text { założeń (\%) }\end{array}$ \\
\hline Energia (kcal) & 1337,7 & 1400 & $96 \%$ \\
Białko (g) & 82,4 & 80 & $103 \%$ \\
Tłuszcz (g) & 49,8 & 47 & $106 \%$ \\
Węglowodany ogółem (g) & 155,0 & 165 & $94 \%$ \\
Węglowodany przyswajalne (g) & 131,6 & 140 & $94 \%$ \\
Błonnik $(\mathrm{g})$ & 23,4 & 25 & $93 \%$ \\
SFA (g) & 9,6 & 11 & $87 \%$ \\
MUFA (g) & 20,9 & 23,5 & $89 \%$ \\
n-3 (g) & 3,0 & & \\
n-6 (g) & 7,0 & & $94 \%$ \\
PUFA (g) & 11,8 & 12,5 & $95 \%$ \\
Cholesterol $(\mathrm{g})$ & 285,2 & 300 & \\
Kw. tł. trans $(\mathrm{g})$ & 0,1 & & $94 \%$ \\
Wapń $(\mathrm{mg})$ & 940,4 & 1000 & $107 \%$ \\
Żelazo $(\mathrm{mg})$ & 10,7 & 10 & $104 \%$ \\
Wit. A $(\mu \mathrm{g})$ & 932,9 & 900 & $42 \%$ \\
Wit. D $(\mu \mathrm{g})$ & 6,4 & 15 & $91 \%$ \\
Wit. B1 $(\mathrm{mg})$ & 1,2 & 1,3 & $92 \%$ \\
Foliany $(\mu \mathrm{g})$ & 366,3 & 400 & 2,4 \\
Wit. B12 $(\mu \mathrm{g})$ & 5,7 & & \\
& & & \\
\hline
\end{tabular}




\section{Podsumowanie}

Podjęcie adekwatnego leczenia (chirurgiczne zmniejszenie objętości żołądka) oraz modyfikacja stylu życia (zastosowanie odpowiedniej diety i wdrożenie aktywności fizycznej) pozwoliło na osiągnięcie znacznej poprawy stanu zdrowia pacjenta. Objawiała się ona polepszeniem wyników badań (unormowaniem lipidogramu i poziomu glukozy), ustąpieniem stłuszczenia wątroby (potwierdzone badaniem ultrasonograficznym), wyeliminowaniem objawów dny moczanowej (zupełne odstawienie leków), redukcją dawek przyjmowanych dotąd środków farmaceutycznych. Ogromnym sukcesem pacjenta było osiągniecie długo wyczekiwanej redukcji masy ciała (o 31\%). Wykonanie zabiegu oraz sumienne przestrzeganie diety doprowadziło do utraty $49 \mathrm{~kg}$ (masa ciała przy końcu badania wynosiła $108 \mathrm{~kg}$, a BMI $31,2 \mathrm{~kg} / \mathrm{m}^{2}$ ). Mężczyzna podkreślał, podobnie jak wielu pacjentów bariatrycznych, że sukces zawdzięcza w dużej mierze rodzinie, która go wspierała i zachęcała do wytrwania w podjętych postanowieniach. Na skutek przebytej operacji pacjent zmodyfikował swój styl życia - oprócz obligatoryjnej zmiany sposobu żywienia wdrożył regularną aktywność fizyczną. Decyzję o poddaniu się operacji zaliczył do najlepszych, jakie podjął w życiu. Wnioskiem z przeprowadzonego badania jest to, że chirurgiczne leczenie otyłości oraz prawidłowa opieka nad pacjentem bariatrycznym (w tym kierownictwo żywieniowe i nadzór dietetyka) doprowadzają do znacznego zmniejszenia masy ciała oraz poprawy stanu zdrowia i samopoczucia.

\section{Bibliografia}

Ciborowska H., Rudnicka A., 2014. Dietetyka. Żywienie zdrowego i chorego człowieka. Wydawnictwo Lekarskie PZWL, Warszawa.

Jarosz M., Rychlik E., Stoś K., Charewska J. (red.), 2020. Normy żywienia dla populacji Polski i ich zastosowanie. NIZP-PZH, Warszawa.

Jastrzębska M., Ostrowska L., 2010. Zalecenia dietetyczne po zabiegach bariatrycznych. Forum Zaburz. Metab. 1(4), 201-209.

Kuczyńska B., Biczysko M., Bogdański P., 2012. Chirurgiczne leczenie otyłości olbrzymiej i zaburzeń metabolicznych. Forum Zaburz. Metab. 3(2), 61-69.

Szczepańska E., Brończyk-Puzoń A., 2014. Ocena nawyków żywieniowych pacjentów z otyłością, zakwalifikowanych do zabiegu bariatrycznego. Med. Og. Nauk. Zdr. 20(3), 330-334. https://doi.org/10.5604/20834543.1124667

Świerzko-Kludzikowska, D.M., 2017. Struktura demograficzna pacjentów otyłych poddających się zabiegom bariatrycznym. Pielęg. Opiece Długoterminowej 4(4), 35-43.

Wyleżoł M., Paśnik K., Dąbrowiecki S., Głuszek S., Michalik M., Strzelczyk J., Wierzbicki Z., Kwiatkowski A., Stanowski E., 2009. Polskie rekomendacje w zakresie chirurgii bariatrycznej. Videosurg. Other Miniinvasive Tech. 4(1),31-34. 
Joanna Mrożek [D1, Aleksandra Pajor ${ }^{1}$, Aneta Koronowicz ${ }^{\mathbb{D}}{ }^{1}$

\section{Wpływ sałaty biofortyfikowanej w jodosalicylany na żywotność komórek nowotworowych - badania in vitro w modelu komórek gruczołu piersiowego MCF-7}

The effect of biofortified lettuce in iodosalicylates on the viability of neoplastic cells - in vitro studies in the MCF-7 breast gland cell model

Rak piersi jest najczęściej diagnozowanym nowotworem u kobiet w Polsce i stanowi drugą w kolejności przyczynę zgonów z powodu nowotworów złośliwych [IARC 2019]. Zaburzenia związane $z$ niedoborem jodu wciąż są globalnym problemem zdrowotnym [WHO 2014]. Ten pierwiastek jest niezbędny do prawidłowego funkcjonowania organizmu człowieka, np. do syntezy hormonów tarczycy, które są kluczowymi regulatorami ludzkiego metabolizmu, wzrostu komórek, proliferacji i apoptozy, a także biorą udział w procesie kancerogenezy [Aceves i in. 2013].

W odpowiedzi na wykazaną w ostatnich latach zależność pomiędzy sposobem żywienia a zdrowiem człowieka, powstała idea żywności funkcjonalnej, która poza dostarczaniem podstawowych składników odżywczych, wykazuje też właściwości prozdrowotne [Zhao i McGrath 2009, Saltzman 2013, Strzetelski 2013]. Sałata biofortyfikowana w jod może być uważana za źródło jodu. Dodatkowo istnieją badania potwierdzające, że ekstrakty z sałaty biofortyfikowanej jodem zmniejszają proliferację komórek nowotworowych [Koronowicz i in. 2016]. Te doniesienia, stwarzają nadzieję na eliminację problemu niedoboru jodu oraz wskazują na potencjał zapobiegania lub leczenia nowotworów.

W niniejszym badaniu oceniano skuteczność ekstraktów z sałaty biofortyfikowanej w jod na ograniczanie żywotności komórek nowotworowych linii MCF-7. Wprowadzenie ekstraktów z sałaty do hodowli komórek gruczolakoraka piersi, powodowało zmniejszenie żywotności komórek w sposób zależny od podanego stężenia i czasu działania ekstraktu.

\section{Material i metody}

\section{Model badawczy}

Modelem badawczym w pracy była nowotworowa linia komórkowa gruczołu piersiowego MCF-7 (ATCC HTB-22). Komórki hodowano w medium MEM (Minimum Essential Medium Eagle, Sigma-Aldrich) z dodatkiem antybiotyku - $100 \mu \mathrm{g} / \mathrm{ml}$ (Sigma Aldrich), $100 \mathrm{mM}$ pirogronianu sodu - $11 \mathrm{mg} / \mathrm{ml}$ (Sigma-Aldrich), 10\% płodowej surowicy

1 Uniwersytet Rolniczy im. Hugona Kołłątaja w Krakowie, Wydział Technologii Żywności, Katedra Żywienia Człowieka i Dietetyki, ul. Balicka 122, 30-149 Kraków, joannaelzbietamrozek@gmail.com 
bydlęcej (FBS, Gibco) oraz $25 \mathrm{mM}$ insuliny - $10 \mathrm{mg} / \mathrm{ml}$ (Sigma-Aldrich). Hodowlę prowadzono w inkubatorze, w stałych warunkach: temp. $37^{\circ} \mathrm{C}$; powietrze $95 \% ; \mathrm{CO}_{2} 5 \%$.

\section{Material badawczy}

Badano ekstrakty z sałaty siewnej (Lactuca sativa L.) biofortyfikowanej w jod z zastosowaniem mineralnej formy tego pierwiastka - jodanu potasu oraz form organicznych - jodosalicylanów: kwasu 5-jodosalicylowego i 3,5-dijodosalicylowego. Sałatę uprawiano zgodnie ze sposobem biofortyfikacji warzyw w jod w uprawach hydroponicznych. Dodatkowo kontrolnie badano również ekstrakt $\mathrm{z}$ sałaty niepoddanej biofortyfikacji. Warianty i oznaczenia przedstawiono w tabeli 1.

Tabela 3. Badane warianty sałaty i jej stężenia

\begin{tabular}{|l|c|c|}
\hline \multicolumn{1}{|c|}{$\begin{array}{c}\text { Ekstrakty z sałaty }- \\
\text { forma jodu do biofortyfikacji }\end{array}$} & $\begin{array}{c}\text { Stosowane } \\
\text { oznaczenia }\end{array}$ & $\begin{array}{c}\text { Badane stężenia } \\
\text { sałaty }(\mathrm{mg} / \mu \mathrm{l}) *\end{array}$ \\
\hline Kontrola - niepoddana biofortyfikacji & SK & 1000 \\
\hline Jodan potasu & S-KIO 3 & 1250 \\
\hline Kwas 5-jodosalicylowy & S-5-I & 1500 \\
\hline Kwas 3,5-dijodosalicylowy & S-3,5-I & \\
\hline
\end{tabular}

*badano jednakowe stężenia dla każdej z czterech prób sałaty, stężenia sporządzano w medium hodowlanym

\section{Metody i schemat postępowania}

\section{Sporządzanie ekstraktów alkoholowych z sałaty i badanych roztworów}

Naważkę $0,7 \mathrm{~g}$ zliofilizowanej sałaty umieszczono w kolbie stożkowej i dodano $100 \mathrm{ml} \mathrm{70 \%} \mathrm{etanolu.} \mathrm{Kolby} \mathrm{wytrząsano} \mathrm{na} \mathrm{wytrząsarce} \mathrm{z}$ łaźnią wodną (120 cykli na minutę, amplituda 8) przez $2 \mathrm{~h} \mathrm{w}$ temperaturze $40^{\circ} \mathrm{C}$. Otrzymane ekstrakty sączono przez sączek bibułowy i przechowywano w temperaturze $-20^{\circ} \mathrm{C}$. Następnie ekstrakty odparowano w wyparce próżniowej w temperaturze $40 \pm 2{ }^{\circ} \mathrm{C}$ i liofilizowano. $\mathrm{Z}$ tak przygotowanego materiału dla każdego $\mathrm{z}$ czterech badanych wariantów sporządzono serię stężeń w medium hodowlanym, jak podano w tabeli 1. Oznaczano wpływ roztworów na proliferację i żywotność badanych komórek. Uproszczony schemat postępowania przedstawiono na rycinie 1 .

\section{Hodowla komórek i przebieg doświadczenia}

Hodowlę komórek prowadzono w butelkach hodowlanych o powierzchni $25 \mathrm{~cm}^{3}$. Komórki do badań żywotności i cytotoksyczności wysiewano na 96-dołkową płytkę w ilości $7 \times 10^{4}$ komórek/dołek.

Po upływie $24 \mathrm{~h}$ wymieniano pożywkę na zawierającą odpowiednie stężenia badanych ekstraktów sałat i kontynuowano hodowlę przez kolejne 24, 48 i 72 h, po czym komórki utrwalano i przechowywano do oznaczenia. Medium zebrane znad komórek traktowanych ekstraktami sałaty przez 24 h przeznaczono do badania cytotoksyczności. 


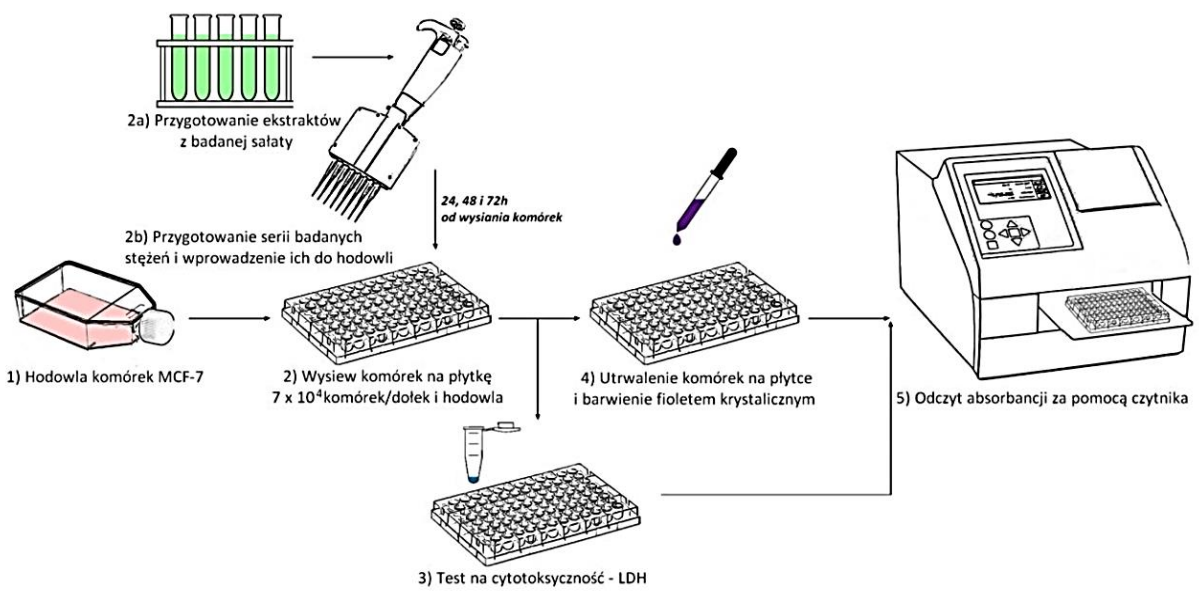

Ryc. 1. Schemat doświadczenia; oprac. wł. na podst. Pajor i Koronowicz [2020]

\section{Oznaczanie cytotoksyczności}

Cytotoksyczność komórek oznaczono, po 24 h od wprowadzenia badanych ekstraktów do hodowli komórkowych, za pomocą zestawu 'Cytotoxity Detection Kit LDH' (Roche), zgodnie z protokołem producenta. Pomiar absorbancji wykonano przy długości fali $\lambda=490 \mathrm{~nm}$, korzystając ze spektrofotometru mikropłytkowego 'Multiskan GO' (Thermo Scientific) i oprogramowania Multiskan GO.

Cytotoksyczność obliczono według wzoru:

$$
\text { Cytotoksyczność }(\%)=\frac{A-B}{C-B} \cdot 100 \%
$$

gdzie:

A - absorbancja próbki badanej

B - absorbancja próbki kontroli negatywnej

C - absorbancja próbki kontroli pozytywnej

Wszystkie oznaczenia były wykonane w trzech powtórzeniach, w trzech niezależnych doświadczeniach.

\section{Oznaczanie żywotności komórek}

Żywotność komórek określono poprzez barwienie fioletem krystalicznym (SigmaAldrich). Absorbancję zmierzono przy długości fali $\lambda=540 \mathrm{~nm}$, korzystając ze spektrofotometru mikropłytkowego (Multiskan GO, Thermo Scientific) i oprogramowania Multiskan GO.

Żywotność komórek obliczono według wzoru:

$$
\text { Żywotność (\% kontroli) }=\frac{A}{B} \cdot 100 \%
$$


gdzie:

A - absorbancja próbki badanej

B - absorbancja próbki kontroli negatywne

Wszystkie oznaczenia były wykonane w trzech powtórzeniach, w trzech niezależnych doświadczeniach.

\section{Wyniki}

\section{Cytotoksyczność}

Badania cytotoksyczności ekstraktów z sałaty względem komórek linii MCF-7, prowadzono przez oznaczenie aktywności dehydrogenazy mleczanowej (LDH) w medium hodowlanym. Z uwagi na to, że medium hodowlane było zmieniane codziennie, badano ilość enzymu uwolnionego w czasie 24 h od wprowadzenia badanych substancji do hodowli. Ekstrakty z sałaty biofortyfikowanej w jod oraz z sałaty kontrolnej nie wywoływały wzrostu aktywności LDH po 24-godzinnej inkubacji z komórkami, a otrzymane wartości nie przekraczały $10 \%$ (tab. 2). Wynik poniżej $10 \%$ świadczy o braku cytotoksycznego efektu badanego czynnika na komórki [Koronowicz i in. 2009].

Tabela 4. Cytotoksyczny wpływ ekstraktów z sałaty względem komórek MCF-7

\begin{tabular}{|c|c|c|c|c|}
\hline \multicolumn{5}{|c|}{ Cytotoksyczność $(\%)$} \\
\hline $\begin{array}{c}\text { Stężenie } \\
(\mu \mathrm{g} / \mathrm{ml})\end{array}$ & SK & S-KIO3 & S-K5-I & S-K3,5-I \\
\hline 100 & $0,90 \pm 0,64$ & $-0,33 \pm 0,24$ & $0,09 \pm 0,09$ & $0,23 \pm 0,16$ \\
\hline 500 & $1,61 \pm 0,81$ & $1,04 \pm 0,37$ & $1,18 \pm 0,13$ & $1,41 \pm 0,25$ \\
\hline 750 & $1,56 \pm 0,10$ & $1,08 \pm 0,37$ & $1,51 \pm 0,31$ & $1,64 \pm 0,07$ \\
\hline 1000 & $1,52 \pm 0,20$ & $1,46 \pm 0,09$ & $2,02 \pm 0,32$ & $3,08 \pm 0,04$ \\
\hline 1250 & $2,07 \pm 0,86$ & $2,01 \pm 0,06$ & $2,21 \pm 0,41$ & $2,46 \pm 0,10$ \\
\hline 1500 & $1,88 \pm 0,81$ & $2,21 \pm 0,25$ & $2,64 \pm 0,24$ & $2,83 \pm 0,21$ \\
\hline
\end{tabular}

*wartości uzyskane \pm SD

\section{Żywotność komórek}

Żywotność komórek linii MCF-7, hodowanych w medium z dodatkiem ekstraktów z sałaty, badano poprzez barwienie komórek fioletem krystalicznym. Wyniki badań wskazują, że żywotność komórek nowotworowych MCF-7 zmniejszała się pod wpływem wszystkich ekstraktów z sałaty biofortyfikowanej, niezależnie od formy jodu zastosowanego do biofortyfikacji roślin. 
Dane zostały przedstawione jako średnia \pm SEM z trzech eksperymentów przeprowadzonych niezależnie, każdy wariant w trzech powtórzeniach $(\mathrm{n}=9)$. Istotność statystyczna została oceniona testem t-Studenta; przyjęto różnice istotnie statystycznie dla *p $<0,05$.

Po 24-godzinnej inkubacji komórek $\mathrm{z}$ ekstraktami sałaty obserwowano istotne zmniejszenie żywotności komórek dla obiektów sałaty, które biofortyfikowano organicznymi związkami jodu. Spadek żywotności nasilał się ze wzrostem stężenia badanych ekstraktów (ryc. 2). W porównaniu z obiektami sałaty niewzbogaconej, najniższą żywotność obserwowano pod wpływem ekstraktów z sałaty biofortyfikowanej w kwas 3,5-dijodosalicylowy (ryc. 2). Wpływ sałaty biofortyfikowanej KIO3 na żywotność komórek MCF-7 był porównywalny z sałatą kontrolną, niewzbogaconą.

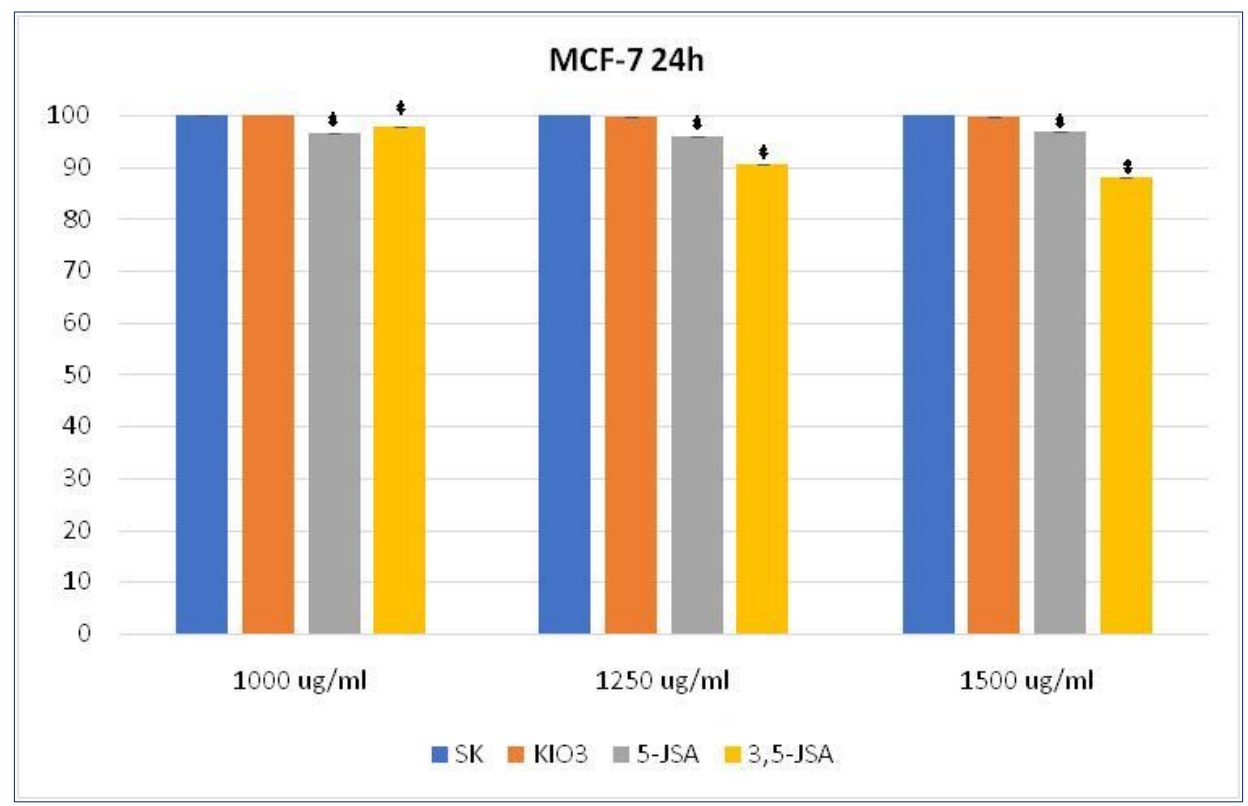

Ryc. 2. Żywotność komórek MCF-7 po 24 h inkubacji z ekstraktami sałaty biofortyfikowanej w związki jodu; różnice istotne statystycznie vs. sałata niewzbogacona (SK)

Po 48-godzinnej inkubacji komórek z ekstraktami sałaty obserwowano istotne zmniejszenie żywotności komórek dla obiektów sałaty biofortyfikowanej w kwas 3,5-dijodosalicylowy oraz jodan potasu (ryc. 3). Największy spadek żywotności komórek (o ok. 34\%) odnotowano pod wpływem ekstraktów z sałaty biofortyfikowanej w kwas 3,5-dijodosalicylowy. Nieznacznie mniejszy wpływ miała sałata biofortyfikowana w jodan potasu, gdzie spadek żywotności odnotowano na poziomie $72 \%$ kontroli. $\mathrm{W}$ porównaniu z sałatą kontrolną, niepoddaną biofortyfikacji, odnotowano istotnie zmniejszoną o 15\% żywotność komórek pod wpływem obiektów sałaty biofortyfikowanej związkami jodu (ryc. 3). 


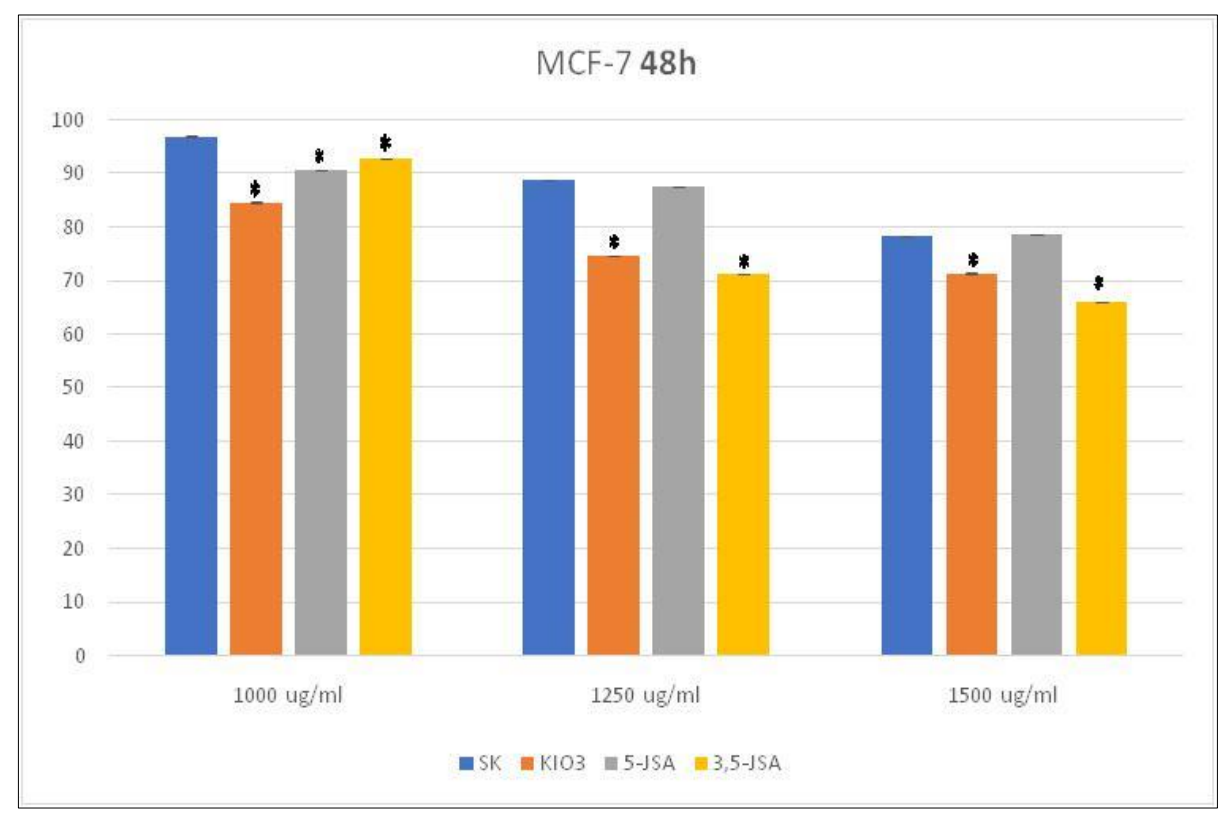

Ryc. 3. Żywotność komórek MCF-7 po 48 h inkubacji z ekstraktami sałaty biofortyfikowanej w związki jodu; różnice istotne statystycznie vs. sałata niewzbogacona (SK)

Wyniki, jakie otrzymano po 72-godzinnej inkubacji komórek z ekstraktami sałaty, wskazują na znaczne zmniejszenie żywotności komórek MCF-7 pod wpływem wszystkich obiektów sałaty (ryc. 4). Największe zmniejszenie żywotności komórek odnotowano pod wpływem ekstraktu z sałaty wzbogaconej w kwas 3,5-dijodosalicylowy. Przy stężeniu $1000 \mu \mathrm{g} / \mathrm{ml}$ żywotność komórek wynosiła 55\% kontroli, przy stężeniu ekstraktów $1250 \mu \mathrm{g} / \mathrm{ml}$ obniżyła się do $49 \%$ kontroli, natomiast przy $1500 \mu \mathrm{g} / \mathrm{ml}$ była na poziomie $42 \%$ kontroli. W porównaniu z sałatą kontrolną, niepoddaną biofortyfikacji, odnotowano również istotnie zmniejszoną o $15 \%$ żywotność komórek pod wpływem ekstraktów z sałaty biofortyfikowanej w kwas 3,5-dijodosalicylowy (ryc. 4).

W przypadku traktowania komórek ekstraktami z sałaty biofortyfikowanej w kwas 5-jodosalicylowy obserwowano istotnie zmniejszoną żywotność komórek do poziomu $50 \%$ kontroli przy najwyższym stężeniu ekstraktu wynoszącycm $1500 \mu \mathrm{g} / \mathrm{ml}$ oraz również istotnie zmniejszoną żywotność w porównaniu z sałatą kontrolną, niepoddaną biofortyfikacji (ryc. 4).

W przypadku komórek inkubowanych z ekstraktem z sałaty biofortyfikowanej w KIO3 obserwowano spadek żywotności na poziomie 60-50\% kontroli jednak w porównaniu z sałatą kontrolną, niepoddaną biofortyfikacji, różnice te nie były jednokierunkowe w obrębie badanych stężeń (ryc. 4).

Należy wskazać, że ekstrakty z sałaty niewzbogaconej również zmniejszały żywotność komórek rakowych linii MCF-7 o ok. 35-45\%. Niemniej wpływ sałaty wzbogaconej w organiczne formy jodu, szczególnie kwas 3,5-dijodosalicylowy, był zwiększony o ponad $10 \%$, co skutkowało zmniejszeniem żywotności o $45-58 \%$. 


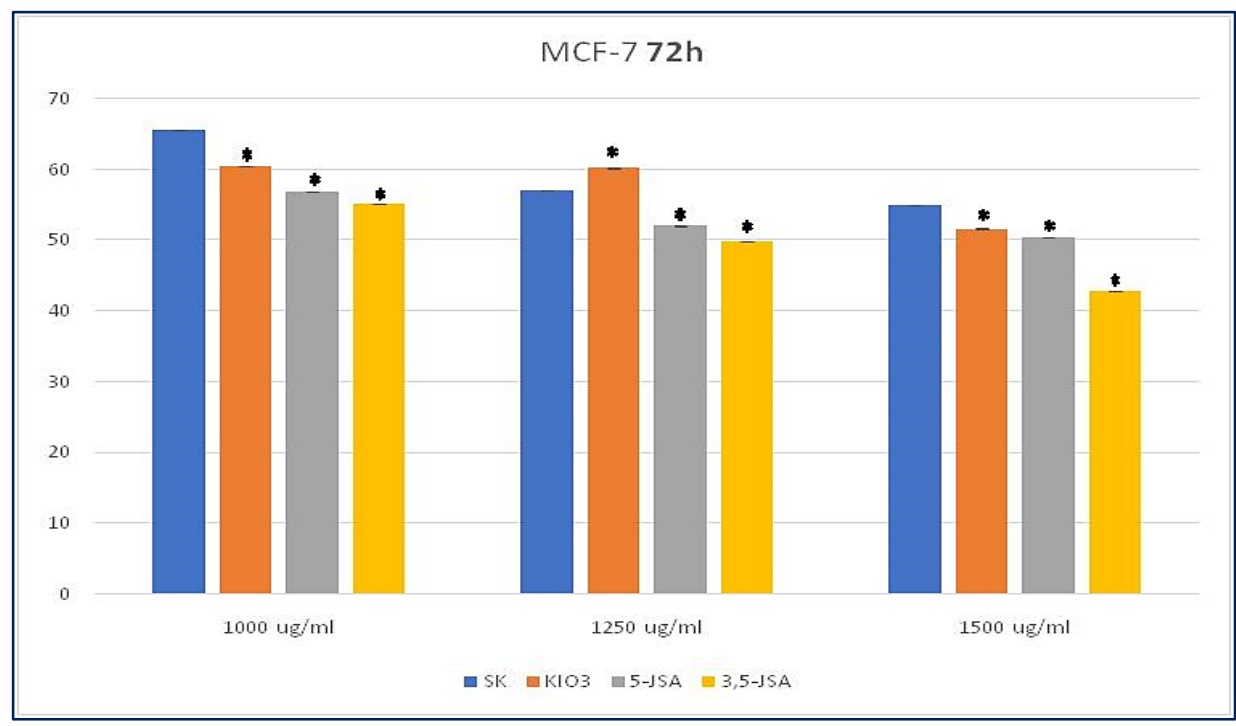

Ryc. 4. Żywotność komórek MCF-7 po 72 h inkubacji z ekstraktami sałaty biofortyfikowanej w związki jodu; *óżnice istotne statystycznie vs sałata niewzbogacona (SK)

\section{Podsumowanie}

Powyższe badanie wykazało, że:

1. Ekstrakty z sałaty biofortyfikowanej jodosalicylanami nie wykazywały cytonekrotycznego wpływu na komórki MCF-7;

2. Ekstrakty $\mathrm{z}$ sałaty biofortyfikowanej w jodosalicylany, szczególnie kwas 3,5-dijodosalicylowy, w porównaniu z obiektami biofortyfikowanymZi w KIO3, w większym stopniu ograniczały żywotność nowotworowych komórek gruczołu piersiowego linii MCF-7;

3. Ekstrakty z sałaty niewzbogaconej zmniejszały żywotność komórek rakowych linii MCF-7, niemniej biofortyfikacja w organiczne formy jodu, szczególnie kwas 3,5-dijodosalicylowy spowodowała nasilenie tego efektu o ponad 10\%;

4. Aby potwierdzić potencjalne znaczenie sałaty biofortyfikowanej w jod w profilaktyce chorób nowotworowych, należy przeprowadzić dalsze badania.

\section{Bibliografia}

Aceves C., Anguiano B., Delgado G., 2013. The extrathyronine actions of iodine as antioxidant, apoptotic, and differentiation factor in various tissues. Thyroid 23(8), 938-946.

IARC (International Agency for Research on Cancer), 2019. The global cancer observatory, March, 2019. Protokół dostępu: www.gco.iarc.fr/today/fact-sheetscancers (21.03.2020).

Koronowicz A., Żwawa K., Szymczyk B., Pisulewski P., Laidler P., 2009. Wpływ lipidów żółtka jaja kurzego naturalnie wzbogaconego w izomery sprzężonego kwasu linolowego na proliferację komórek czerniaka ludzkiego. Brom. Chem. Toksykol. 42(3), 1047-1051. 
Koronowicz A., Kopeć A., Master A., Smoleń S., Piątkowska E., Bieżanowska Kopeć R., KapustaDuch J., 2016. Transcriptome profiling of Caco-2 cancer cell line following treatment with extracts from iodine-biofortified lettuce (Lactuca sativa L.). PloS one, 11(1), e0147336.

Pajor A., Koronowicz A., 2020. Ocena wpływu sałaty biofortyfikowanej w jodosalicylany na żywotność komórek nowotworowych gruczołu piersiowego. Praca magisterska. Uniwersytet Rolniczy w Krakowie.

Saltzman A., Birol E., Bouis H.E., Boy E., De Moura F.F., Islam Y., Pfeiffer W.H., 2013. Biofortification: progresstoward a morenourishingfuture. Global Food Secur. 2(1), 9-17.

Strzetelski P., 2013. Biofortyfikacja roślin w jod. Aura (6), 23-26.

Zhao F. J., McGrath S.P., 2009. Biofortification and phytoremediation. Curr. Opin. Plant Biol. 12(3), 373-380.

WHO, 2014. Guideline: fortification of food-grade salt with iodine for the prevention and control of iodine deficiency disorders. World Health Organization, Geneva. 
Rafał Oleszczuk ${ }^{2}$, Agnieszka M. Grzebalska ${ }^{1}$, Michał Smyka ${ }^{2}$, Jakub Mendocha

\section{Pozytywny i negatywny wpływ witaminy D na organizm człowieka}

Positive and negative influence of vitamin $\mathrm{D}$ on the human body

Witamina D to grupa związków chemicznych, należących do steroidów rozpuszczalnych w tłuszczach. Zalicza się do niej cholekalcyferol (witamina $\mathrm{D}_{3}$ ) i ergokalcyferol (witamina $\mathrm{D}_{2}$ ), które są prekursorami hormonów odgrywających ważną rolę w regulacji gospodarki wapniowo-fosforanowej. Witamina $\mathrm{D}_{2}$ występuje naturalnie w produktach spożywczych pochodzenia roślinnego, natomiast witamina $\mathrm{D}_{3} \mathrm{w}$ produktach pochodzenia zwierzęcego oraz jest syntetyzowana w skórze pod wpływem światła ultrafioletowego [Kulda 2012, Glenville 2018]. Witamina D jest niezbędna wszystkim kręgowcom do utrzymania prawidłowego stężenia wapnia i fosforu we krwi. Jest budulcem szkieletu, jak również odpowiada za kurczenie się mięśni i prawidłowe funkcje komórkowe [Jones $i$ in. 1998]. Postęp diagnostyki medycznej pozwala na dokładne mierzenie stężenia witaminy D. Ma to istotne znaczenie, bowiem zarówno hipo-, jak i hiperwitaminoza są zagrożeniem dla zdrowia. Odkrycie witaminy D i jej znaczenia dla ludzkiego zdrowia doprowadziło do powszechnego wzbogacania w nią żywności, np. mleka. Obecnie stosuje się syntetyczne analogi witaminy D, które naśladują jej fizjologiczne działanie [Glenville 2018]. Witamina D jest aktualnie jednym z najbardziej propagowanych suplementów diety. W poniższym opracowaniu, na podstawie najnowszej wiedzy medycznej i rekomendacji, przedstawiono zarówno pozytywny, jak i negatywny wpływ witaminy D na organizm człowieka. Do zgłębienia problemu wykorzystano artykuły zawarte w bazie danych UpToDate oraz prace naukowe wyszukane w bazie danych PubMed i Medline.

\section{Rys historyczny}

Witaminę D odkryto, szukając przyczyny występowania krzywicy - porównywano wpływ czynników środowiskowych oraz niedoborów w diecie. Theobald Palm, który pod koniec XIX w. prowadził badania w Japonii i Chinach, zasugerował, że wpływ na występowanie krzywicy ma szerokość geograficzna i związana z tym ekspozycja na światło. W związku z tym rozpoczęto próby leczenia krzywicy u zwierząt, a następnie u dzieci, stosując ekspozycję na światło słoneczne i lampy rtęciowe. Badania nad znaczeniem diety w krzywicy prowadził m.in. Casimir Funk. Udowodnił on zasadniczy wpływ niektórych substancji rozpuszczalnych w wodzie lub w tłuszczach. Opierając się na tym pomyśle,

${ }^{1}$ Uniwersytet Medyczny w Lublinie, Wydział Lekarski, Katedra i Klinika Nefrologii Uniwersytetu Medycznego w Lublinie

${ }^{2}$ Uniwersytet Medyczny w Lublinie, Wydział Lekarski, Studenckie Koło Naukowe przy Katedrze i Klinice Nefrologii Uniwersytetu Medycznego w Lublinie, rafal.ole@gmail.com 
Edward Mellanby wykazał, że półsyntetyczna dieta owsiana pozbawiona ,jakiegoś” czynnika może wywołać krzywicę u psów rasy beagle, a wyleczyć je można, podając tran z wątroby dorsza. McCollum z zespołem wykazali, że tajemniczą substancją występującą w oleju z wątroby dorsza, różniącą się od witaminy A, jest witamina D. Pozostał dylemat, dlaczego wpływ na krzywicę ma zarówno światło słoneczne, jak i dieta. Steenbock przeprowadził ostateczny eksperyment - napromieniowanie niektórych pokarmów (np. olejów roślinnych lub drożdży) zwiększyło w nich aktywność witaminy D. Jednak w owym czasie dokładny chemiczny charakter witaminy D był nadal nieznany. Pod koniec lat dwudziestych ubiegłego wieku Adolf Windaus wyjaśnił strukturę kilku steroli, w tym witaminy $\mathrm{D}_{3}$ i 7-dehydrocholesterolu, prekursora witaminy $\mathrm{D}_{3}$ w skórze, dzięki czemu otrzymał w 1928 r. Nagrodę Nobla. Witamina $\mathrm{D}_{3}$ była pierwszą syntetyzowaną witaminą od późnych lat trzydziestych XX w. Dopiero jednak 50 lat po odkryciu świat zaczął rozumieć jej metabolizm i wpływ na stężenie wapnia i fosforu we krwi. Hector DeLuca w 1968 r. odkrył pierwszy aktywny metabolit witaminy D powstający w wątrobie - 5-hydroksywitaminę $\mathrm{D}_{3}$ (25-OH-D3) [Glenville 2018].

\section{Naturalne źródla}

Bardzo niewiele pokarmów naturalnie zawiera witaminę D (wyjątkiem są thuste wątróbki rybne). W związku z tym synteza skórna jest głównym naturalnym źródłem witaminy. Prewitamina $D_{3}$ jest syntetyzowana nieenzymatycznie w skórze z 7-dehydrocholesterolu podczas ekspozycji na promienie ultrafioletowe (UV) w świetle słonecznym. Prewitamina $\mathrm{D}_{3}$ ulega zależnemu od temperatury przekształceniu, tworząc witaminę $\mathrm{D}_{3}$. Taka produkcja jest bardzo skuteczna i szacuje się, że krótkotrwała, przypadkowa ekspozycja rąk i twarzy odpowiada spożyciu 200 jednostek witaminy D dziennie [Haddad 1992]. Należy jednak pamiętać, że ilość światła zależna jest od szerokości geograficznej, pory roku oraz pory dnia. Badania wskazują godzinę 12.00 na szczytowy moment syntezy witaminy D. Wykazano, że najtrudniej synteza witaminy D przebiega w okresie zimowym, a najintensywniej zachodzi u osób z jasną karnacją skóry [Terushkin i in. 2010]. W Polsce największa synteza zachodzi od kwietnia do października, od 10.00 do 15.00 [Pludowski i in. 2018].

Najwięcej witaminy D zawierają ryby, zwłaszcza ich wątroba i tran - odpowiednio od $<2 \mu \mathrm{g} / \mathrm{kg}$ do $477 \mu \mathrm{g} / \mathrm{kg}$ i do $1200 \mu \mathrm{g} / \mathrm{kg}$, w zależności od gatunku ryb. Również podroby dostarczają znacznych ilości witaminy D (do $140 \mu \mathrm{g} / \mathrm{kg}$ ), podczas gdy zawartość w mięsie jest na ogół dużo mniejsza (do $10 \mu \mathrm{g} / \mathrm{kg}$ ). Mleko i produkty mleczne mają zwykle niską zawartość witaminy D, jeśli nie są nią wzbogacone. Najwyższe wartości naturalne odnotowano w maśle i serze (do $10 \mu \mathrm{g} / \mathrm{kg}$ ) ze względu na wysoką zawartość tłuszczu [Schmid i Walther 2013].

\section{Metabolizm}

Witamina D pochodząca z pożywienia lub syntezy skórnej jest biologicznie nieaktywna i wymaga enzymatycznej konwersji w wątrobie i nerkach do aktywnych metabolitów. Pochodząca $\mathrm{z}$ diety witamina jest transportowana $\mathrm{z}$ wiążącym ją białkiem do wątroby, a następnie wiąże się z chylomikronami i lipoproteinami, w celu metabolizowania 
jej wraz z endogenną postacią. Enzym wątrobowy 25-hydroksylaza umieszcza grupę hydroksylową w pozycji 25 cząsteczki witaminy D, w wyniku czego powstaje 25 -hydroksywitamina D [25(OH) D, kalcydiol]. 25-hydroksywitamina $\mathrm{D}_{2}$ ma mniejsze powinowactwo niż 25-hydroksywitamina $\mathrm{D}_{3}$ do białka wiążącego witaminę $\mathrm{D}$. Skraca to okres półtrwania witaminy $\mathrm{D}_{2}$, dlatego też podejmowane próby leczenia niedoborów tą postacią były mniej skuteczne [Brown 1999, Christakos i in. 2010].

25-hydroksywitamina $\mathrm{D}_{2}$ i $\mathrm{D}_{3}$ wytwarzane przez wątrobę ponownie połączone $\mathrm{z}$ białkiem wiążącym witaminę D przedostają się do krwiobiegu i dostają do nerek. W kanalikach nerkowych wyżej wymieniony kompleks przedostanie się do komórek dzięki endocytozie zależnej od receptora. W procesie tym uczestniczą co najmniej dwa białka działające w tandemie: kubilina i megalina. Kubilina i megalina znajdujące się w proksymalnym kanaliku nerkowym są receptorami, które ułatwiają wychwyt ligandów zewnątrzkomórkowych. Niedobór któregokolwiek z tych białek skutkuje zwiększonym wydalaniem $25(\mathrm{OH}) \mathrm{D}$ z moczem i, przynajmniej w modelach eksperymentalnych, niedoborem 1,25-dihydroksywitaminy D i chorobami kości [Nykjaer i in. 2001].

Komórki kanalików nerkowych zawierają dwa enzymy, 1-alfa-hydroksylazę i 24alfa-hydroksylazę, które mogą dalej hydroksylować $25(\mathrm{OH}) \mathrm{D}$, wytwarzając 1,25-dihydroksywitaminę D, najbardziej aktywną formę witaminy D, oraz 24,25-dihydroksywitaminę D, czyli nieaktywny metabolit [Kawashima i in. 1981]. Enzym 1-alfa-hydroksylaza występuje również pozanerkowo, w tym w przewodzie pokarmowym, skórze, naczyniach krwionośnych, komórkach nabłonka sutka, osteoblastach i osteoklastach [Hewison i in. 2007].

Ostateczne stężenie 1,25-dihydroksywitaminy D w osoczu jest zależne tak od dostępności substratów, jak i aktywności enzymów nerkowych - 1-alfa-hydroksylazy i 24alfa-hydroksylazy. Aktywność tych enzymów zależna jest z kolei od wydzielania parathormonu (PTH), stężenia wapnia i fosforanów w surowicy oraz od czynnika wzrostu fibroblastów 23 (FGF23) [Christakos i in. 2010]

\section{Odpowiednia dawka}

W ogólnej populacji, uważanej za zdrową, wybór wytycznych dotyczących suplementacji witaminy D powinien być dostosowany do grupy wiekowej, średniej masy ciała, pochodzenia etnicznego (typu skóry) i szerokości geograficznej miejsca zamieszkania.

Przed publikacją amerykańskiego Instytutu Medycyny (IOM) z 2010 r., zalecane dzienne spożycie witaminy D do 50 r.ż. wynosiło 200 IU/dzień. Zalecenie to opierało się na przekonaniu, że taka dawka wystarczy, aby zapobiec krzywicy. Jednak założenie to pomijało wszystkie inne fizjologicznie korzystne działania witaminy D. W 2010 r. IOM uznał $200 \mathrm{IU} /$ dobę za nieodpowiednią i zalecił $400 \mathrm{IU} / \mathrm{d}$ dla niemowląt, $600 \mathrm{IU} /$ dobę dla dzieci, młodzieży i dorosłych oraz $800 \mathrm{IU} /$ dobę, a u dorosłych w wieku powyżej 70 lat dostosowanie dawki, aby utrzymać pożądane stężenie $25(\mathrm{OH}) \mathrm{D}$. Jednak większość badań obejmujących stężenia $25(\mathrm{OH}) \mathrm{D}$ w celu analizy zależności między zdrowiem a ryzykiem chorób wskazywała na konieczność uzyskania jego większego stężenia [Pludowski i in. 2018].

W 2013 r. ukazały się zalecenia dla Europy Środkowej, w których zwrócono uwagę na problem niedoboru witaminy $\mathrm{D} w$ tym regionie. W przeciwieństwie do wytycznych IOM, zalecenia dla Europy Środkowej zostały opracowane z uwzględnieniem dowodów dotyczących zarówno szkieletowego, jak i plejotropowego wpływu witaminy D, a zatem 
są one istotniejsze w praktyce klinicznej. Wytyczne europejskie zalecają stosowanie suplementów witaminy D, aby uzyskać i utrzymać optymalne docelowe stężenie 25(OH)D wynoszące 30-50 ng/ml [Pludowski i in. 2013].

Najnowsze zalecenia rekomendują spożycie przez noworodki i niemowlęta witaminy D w ilości $400 \mathrm{IU} /$ dobę do 6. m.ż., natomiast później powinno to być 400-600 IU/dobę, w zależności od spożywanej ilości w pokarmie. U dzieci do 18 r.ż. podaż w miesiącach od września do kwietnia powinna być utrzymywana w granicach 600-1000 IU/dobę, a przez pozostałą część roku zależna od ekspozycji na promieniowanie słoneczne. Dorośli powinni przyjmować 800-2000 IU witaminy D dziennie od września do kwietnia, a w miesiącach letnich suplementację dostosować do ekspozycji na promieniowanie słoneczne. Osoby po 65 r.ż. powinny utrzymywać stałą suplementację witaminy D przez cały rok. Należy zapewnić odpowiednią podaż witaminy D również przed ciążą, a kobiety planujące ciążę powinny rozpocząć i utrzymywać suplementację zgodnie z zaleceniami dla dorosłych. Kobietom w ciąży suplementację witaminy D w dawce 1500 $2000 \mathrm{IU} /$ dobę należy rozpocząć co najmniej od drugiego trymestru ciąży. Jeśli to możliwe, zalecane jest przeprowadzanie okresowego monitorowania stężenia $25(\mathrm{OH}) \mathrm{D}$ w surowicy, aby określić optymalną dawkę i zweryfikować skuteczność suplementacji. Celem suplementacji jest osiągnięcie i utrzymanie stężenia 25(OH)D wynoszącego $30-50 \mathrm{ng} / \mathrm{ml}$ [Płudowski i in. 2018].

\section{Ocena stężenia witaminy D}

Najlepszym laboratoryjnym wskaźnikiem stężenia witaminy D jest stężenie $25(\mathrm{OH}) \mathrm{D}$ w surowicy wyrażone w nanogramach na mililitr lub w nanomolach na litr. Całkowite jego stężenie odzwierciedla dostarczanie z obu źródeł - syntezy skórnej i dostarczane zewnątrzustrojowo. Dolna granica normy różni się w zależności od położenia geograficznego i ekspozycji populacji na światło słoneczne. Jednak nie ma jednego wspólnego zdania co do optymalnego stężenia $25(\mathrm{OH}) \mathrm{D}$ dla zdrowia. Wytyczne dla Europy Środkowej wskazują, że o niedoborze witaminy D można mówić, gdy stężenie 25(OH)D jest mniejsze niż 20 ng/ml. Gdy wartość wynosi między 20 a 30 ng/ml, stwierdza się nieodpowiednie stężenie witaminy D i zaleca zwiększyć jej ilość dostarczaną do organizmu. Za prawidłowe stężenie uważa się 30-50 ng/ml 25(OH)D. Gdy zostanie przekroczona górna granica, suplementacja witaminy D powinna zostać zmniejszona. Stężenia powyżej $100 \mathrm{ng} / \mathrm{ml}$ 25(OH)D są ryzykowne dla zdrowia, a wyższe niż $200 \mathrm{ng} / \mathrm{ml}$ uważane są już za toksyczne. Oba te stany wymagają zaprzestania suplementacji witaminy D, aż do osiągnięcia wartości normy [Płudowski i in. 2013].

\section{Zaburzenia stężenia witaminy D}

\section{Niedobór witaminy D}

Niedobór lub oporność witaminy D są spowodowane jednym z czterech mechanizmów:

- upośledzoną dostępnością witaminy D, wynikającą z nieodpowiedniej jej ilości w diecie, zaburzeń wchłaniania tłuszczu i/lub braku światła słonecznego, 
- upośledzoną hydroksylacją w wątrobie (zmniejszenie produkcji 25-hydroksywitaminy D),

- upośledzoną hydroksylacją w nerkach (zmniejszenie produkcji 1,25-dihydroksywitaminy D) - obserwowana w zależnej od witaminy D krzywicy typu 1 lub przewlekłej chorobie nerek,

- niewrażliwością narządów końcowych na metabolity witaminy D (dziedziczna krzywica oporna na witaminę $\mathrm{D}$, krzywica zależna od witaminy D typu 2).

Grupą podwyższonego ryzyka niedoboru witaminy D w surowicy są osoby starsze przebywające $\mathrm{w}$ zamkniętych pomieszczeniach. Związane jest to ze zmniejszeniem z wiekiem skórnej produkcji 25(OH)D, szczególnie nasilone w północnych szerokościach geograficznych [MacLaughlin i in. 1985]. Niedobór witaminy D wydaje się powszechny wśród kilku innych populacji, a w szczególności u osób o ciemnej karnacji, otyłych, przyjmujących leki przyśpieszające metabolizm witaminy D (np. fenytoinę), hospitalizowanych, ograniczających ekspozycję na słońce, chorych na osteoporozę lub z zaburzeniami wchłaniania jelitowego [Dawson-Hughes 2020].

Kliniczne objawy niedoboru witaminy D zależą od ciężkości i czasu trwania niedoboru. U większości pacjentów z umiarkowanym niedoborem witaminy D [25(OH)D poziom w surowicy między 15 a $20 \mathrm{ng} / \mathrm{ml}$ objawy nie występują. Zawartość wapnia, fosforu i fosfatazy alkalicznej w surowicy są zwykle prawidłowe. Stwierdzono, że stężenie PTH w surowicy jest większe u 40\% i 51\% pacjentów ze stężeniem 25(OH)D w surowicymniejszym niż odpowiednio 20 i $10 \mathrm{ng} / \mathrm{ml}$ [Valcour i in. 2012]. Pacjenci z niskim stężeniem witaminy D i wtórnym podwyższeniem PTH są narażeni na zwiększone ryzyko przyspieszonej utraty masy kostnej, o czym świadczą nieprawidłowe wyniki badań densytometrycznych kości i liczne złamania [Cauley i in. 2010, Garg i in. 2014]. Przy ciężkim niedoborze witaminy D dochodzi do zmniejszonego wchłaniania wapnia i fosforu w jelitach, a w efekcie do hipokalcemii, powodującej wtórną nadczynność przytarczyc, która prowadzi do fosfaturii, demineralizacji kości, a ostatecznie do osteomalacji u dorosłych oraz krzywicy i osteomalacji u dzieci. Występującymi objawami są wtedy: ból i tkliwość kości, osłabienie siły mięśni, złamania i trudności w chodzeniu [Cohen i Drake 2020]. Badania obserwacyjne sugerują związek między niskim stężeniem witaminy D $(<10$ lub $<20 \mathrm{ng} / \mathrm{ml})$ a osłabieniem mięśni u dzieci i osób starszych [Visser i in 2003, Wicherts i in. 2007]. Badaniem, które wykazało związek między genetycznie uwarunkowanym niskim stężeniem 25(OH)D a ryzykiem raka jajnika było badanie Onga $i$ in. [2016]. Grupa robocza Światowej Organizacji Zdrowia (WHO) zidentyfikowała również związek między niedoborem witaminy D a ryzykiem raka okrężnicy. To stwierdzenie jest poparte wynikami analizy danych dotyczących 5706 przypadków raka jelita grubego i 7107 kontroli [Wicherts i in. 2007]. W porównaniu ze stężeniem 25(OH)D wynoszącym od 20 do $<25 \mathrm{ng} / \mathrm{ml}$, stężenie mniejsze niż $12 \mathrm{ng} / \mathrm{ml}$ było związane z większym ryzykiem wystąpienia raka jelita grubego, podczas gdy stężenie równe lub wyższe niż $30 \mathrm{ng} / \mathrm{ml}$ wiązały się z mniejszym ryzykiem [McCullough i in. 2019]. Obecne dowody są jednak niewystarczające, aby zalecać suplementację witaminy D w dużych dawkach w celu zapobiegania rakowi, choć suplementacja jest zalecana w przypadku pacjentów z jawnym niedoborem. Badania dotyczące wpływu witaminy D nie wykazują zmniejszenia ryzyka nowotworów [Scragg i in. 2018, Keum i in. 2019]. 
Istnieje szereg badań dotyczących wpływu niedoboru witaminy D na różne schorzenia, np. choroby układu sercowo-naczyniowego, cukrzycę. Chociaż badania obserwacyjne wykazują związek między niskim stężeniem witaminy D a ryzykiem nadciśnienia i incydentów sercowo-naczyniowych, większość badań z randomizacją nie wykazała korzyści sercowo-naczyniowych z suplementacji witaminy D [Theodoratou i in. 2014]. Niektóre badania obserwacyjne sugerują związek między niedoborem witaminy D a cukrzycą typu 1. W badaniu kliniczno-kontrolnym, które obejmowało 720 dzieci z cukrzycą typu 1 oraz 2610 dobranych wiekowo dzieci bez cukrzycy, stwierdzono zależność między cukrzycą typu 1 a kluczowymi polimorfizmami genetycznymi związanymi z niedoborem witaminy D. [Cooper i in. 2011]. Kilka badań obserwacyjnych wykazało, że suplementacja witaminą D we wczesnym dzieciństwie zmniejszyła późniejsze ryzyko cukrzycy typu 1 o około 30\% [Zipitis i Akobeng 2008, Dong i in. 2013]. Małe stężenie 25(OH)D jest także często stwierdzane u pacjentów z depresją lub chorobą Alzheimera [Anglin $\mathrm{i}$ in. 2013].

\section{Nadmiar witaminy D}

Toksyczność witaminy D pozostaje problemem dla lekarzy i agencji zdrowia publicznego, z powodu którego rządy opierają się wprowadzaniu żywności wzbogaconej witaminą $\mathrm{D}$, jak mleko i produkty mleczne, mimo braku najnowszych danych naukowych. Przed rokiem 1950 powszechne było wzbogacanie produktów spożywczych witaminą D, które wynikało z uznania jej za jeden z „cudownych składników odżywczych”, przydatnych w leczeniu chorób przewlekłych od gruźlicy po reumatoidalne zapalenie stawów [Płudowski i in. 2018].

Pierwszym objawem nadmiaru witaminy $\mathrm{D}$ jest zwiększone wydalanie wapnia $\mathrm{z}$ moczem w wyniku zmniejszenia jego wchłaniania z kanalików nerkowych, wtórnego do niskiego stężenia PTH. Nadmiar witaminy D generuje również zwiększone wchłanianie wapnia i fosforanów z pożywienia. W efekcie ich stężenie w surowicy wzrasta. Wzrost stężenia fosforanów jest dodatkowo spotęgowany spadkiem ich wydalania przez nerki. Ostatecznym efektem jest przesycenie produktu fosforanu wapnia $(\mathrm{CaxP}>55)$, który odkłada się w tkankach miękkich, w tym w nerkach, powodując nefrokalcynozę i zwapnienie naczyń. Długotrwałym efektem tego stanu może być niereagujące na leczenie nadciśnienie tętnicze, przewlekła choroba nerek, a nawet konieczność leczenia dializoterapią [Holick 2015].

Objawy kliniczne toksyczności witaminy D to skutki hiperkalcemii. Obejmują one objawy neurologiczne (splątanie, apatia, pobudzenie, drażliwość, a w ciężkich przypadkach otępienie), objawy żołądkowo-jelitowe (bóle brzucha, nudności, wymioty, zaparcia, wrzody trawienne i zapalenie trzustki) i objawy nerkowe (wielomocz, polidypsja, kamica nerkowa). Ciężka hiperkalcemia może również prowadzić do arytmii serca. W przypadkach umiarkowanej hiperkalcemii objawy mogą być niespecyficzne: osłabienie, zmęczenie, anoreksja i bóle kości. Rzadkim objawem toksyczności witaminy D jest również zapalenie trzustki, prowadzące do powikłań [Kaur i in. 2015]. Fizyczne badanie pacjentów z objawami toksyczności czasami wykazuje utratę jędrności skóry i suchość błon śluzowych (z powodu odwodnienia), zmiany stanu psychicznego, tkliwość brzucha, sztywność lub obronę mięśniową. W innych przypadkach wynik badania przedmiotowego może być 
normalny, bez żadnych odchyleń, ale należy pamiętać o podejrzeniu toksyczności witaminy D w oparciu o ustalenia z wywiadu [Asif $\mathrm{i}$ in. 2020].

Częstość występowania problemu toksyczności witaminy D prawdopodobnie się zwiększy, zarówno z powodu rosnącego zainteresowania tą witaminą, jak i powszechnego jej przepisywania przez lekarzy. Taylor i in. [2018] wskazują na możliwe trzy główne tego przyczyny: błędy w produkcji suplementów diety, niewłaściwe przepisywanie i wydawanie witaminy $\mathrm{D}$ oraz nieprawidłowe przyjmowanie jej przez pacjentów (zwiększone dawki). Konsekwencje takich działań dla pacjentów są długofalowe. W świetle możliwego wystąpienia powikłań kontrowersyjne staje się zalecanie stosowania preparatów z witaminą D w nieodpowiedniej dawce, bez uprzedniego zbadania jej stężenia i przeszkolenia pacjentów.

\section{Witamina D a COVID-19}

Zwiększa się zainteresowanie rolą witaminy D, jako czynnika wspomagającego wrodzoną odpowiedź immunologiczną podczas zakażenia SARS-CoV-2. Stężenie 25(OH)D w surowicy jest podobno niższe u pacjentów w stanie krytycznym (na oddziale intensywnej terapii) z COVID-19 niż u pacjentów na oddziale ogólnym [Lau i in. 2020]. Chociaż małe liczebnościowo badania obserwacyjne wskazują na odwrotną zależność między średnimi stężeniami witaminy D a przypadkami COVID-19, związek ten jest trudny do oceny przez wspólne czynniki ryzyka zarówno niedoboru witaminy D, jak i SARS-CoV-2 (np. otyłość) [Ali 2020]. W dużym badaniu kohortowym przeprowadzonym przez Biobank w Wielkiej Brytanii, po uwzględnieniu czynników zakłócających, nie stwierdzono związku między stężeniami 25(OH)D a ryzykiem zachorowania lub śmiertelnością z powodu COVID-19 [Hastie i in. 2021]. W kolejnym badaniu 489 osób, u których stężenie $25(\mathrm{OH}) \mathrm{D}$ zostało zbadane w ciągu jednego roku od wykonania testu na COVID-19, ryzyko pozytywnego wyniku testu było wyższe u tych, którzy prawdopodobnie mieli niedobór witaminy $\mathrm{D}$ [Meltzer i in. 2020]. Nie ma jednak wyraźnych dowodów na to, że suplementacja witaminy D zmniejsza ryzyko lub nasilenie COVID-19 [Lau i in. 2020].

\section{Podsumowanie}

Problemem jest zarówno niedobór, jak i nadmiar witaminy $\mathrm{D}$, a konsekwencje są tak samo poważne. Dlatego w praktyce klinicznej należy podchodzić z rozwagą do suplementacji tej witamy, w pierwszej kolejności oznaczając stężenie i zapotrzebowanie pacjenta, uwzględniając wyżej wymienione czynniki i grupy ryzyka. Należy również edukować społeczeństwo, korzystając z najnowszych doniesień naukowych o efektach stosowania takich preparatów.

\section{Bibliografia}

Ali N., 2020. Role of vitamin D in preventing of COVID-19 infection, progression and severity. J. Infect. Public. Health. 13(10), 1373-1380. https://doi.org/10.1016/j.jiph.2020.06.021 
Anglin R.E., Samaan Z., Walter S.D., McDonald S.D. 2013. Vitamin D deficiency and depression in adults: systematic review and meta-analysis. Br. J. Psychiatry 202, 100-107. https://doi.org/10.1192/bjp.bp.111.106666

Asif A., Farooq N. 2020. Vitamin D toxicity. [Updated 2020 May 21]. In: StatPearls [Internet]. Treasure Island (FL): StatPearls Publishing. https://www.ncbi.nlm.nih.gov/books/NBK557876/ [dostęp 24.03.2021]

Brown A.J., 1999. Regulation of vitamin D action. Nephrol. Dial. Transplant. 14(1), 11-16. https://doi.org/10.1093/ndt/14.1.11

Cauley J.A., Parimi N., Ensrud K.E., Bauer D.C., Cawthon P.M., Cummings S.R., Hoffman A.R., Shikany J.M., Barrett-Connor E., Orwoll E., 2010. Osteoporotic Fractures in Men (MrOS) Research Group. Serum 25-hydroxyvitamin D and the risk of hip and nonspine fractures in older men. J. Bone Miner. Res. 25(3), 545-553. https://doi.org/10.1359/jbmr.090826

Christakos S., Ajibade D.V., Dhawan P., Fechner A.J., Mady L.J., 2010. Vitamin D: metabolism. Endocrinol. Metab. Clin. North Am. 39(2), 243-253 https://doi.org/10.1016/j.ecl.2010.02.002

Cohen A., Drake M.T., 2020. Clinical manifestations, diagnosis, and treatment of osteomalacia, https://www.uptodate.com/contents/clinical-manifestations-diagnosis-and-treatment-of-osteomalacia?search=clinical $\% 20$ manifestations $\% 20$ of\%20osteomalacja\&source=search_result\&selectedTitle=1 143\&usage_type=default\&display_rank=1 [dostęp 24.03.2021]

Cooper J.D., Smyth D.J., Walker N.M., Stevens H., Burren O.S., Wallace C., Greissl C., RamosLopez E., Hyppönen E., Dunger D.B., Spector T.D., Ouwehand W.H., Wang T.J., Badenhoop K., Todd J.A., 2011. Inherited variation in vitamin D genes is associated with predisposition to autoimmune disease type 1 diabetes. Diabetes 60(5), 1624-1631. https://doi.org/10.2337/db101656

Dawson-Hughes B., 2020. Vitamin D deficiency in adults: definition, clinical manifestations, and treatment. Uptodate.com https://www.uptodate.com/contents/vitamin-d-deficiency-in-adultsdefinition-clinical-manifestations-and-treatment?search=vitamin $\% 20 \mathrm{~d} \% 20 \mathrm{deficiency} \&$ source $=$ search_result\&selectedTitle $=1 \sim 150 \&$ usage_type $=$ default\&display_rank $=1 \quad$ [dostęp 25.03.2021]

Dong J.Y., Zhang W.G., Chen J.J., Zhang Z.L., Han S.F., Qin L.Q., 2013. Vitamin D intake and risk of type 1 diabetes: a meta-analysis of observational studies. Nutrients 12, 5(9), 3551-3562. https://doi.org/10.3390/nu5093551

Lau F.H., Majumder R., Torabi R., Saeg F., Hoffman R., Cirillo J.D., Greiffenstein P., 2020. Vita$\min \mathrm{D}$ insufficiency is prevalent in severe COVID-19 medRxiv. https://doi.org/10.1101/2020.04.24.20075838

Garg M.K., Tandon N., Marwaha R.K., Menon A.S., Mahalle N., 2014. The relationship between serum 25-hydroxy vitamin $\mathrm{D}$, parathormone and bone mineral density in Indian population. Clin. Endocrinol. (Oxf). 80(1), 41-46. https://doi.org/10.1111/cen.12248

Glenville J., 2018. The discovery and synthesis of the nutritional factor vitamin D. Int. J. Paleopathol. 23, 96-99.

Haddad J.G., 1992. Vitamin D - solar rays, the Milky Way, or both? N. Engl. J. Med. 30, 326(18), 1213-1215. https://doi.org/10.1056/NEJM199204303261808

Hastie C.E., Pell J.P., Sattar N., 2021. Vitamin D and COVID-19 infection and mortality in UK Biobank. Eur. J. Nutr. 60(1), 545-548. https://doi.org/10.1007/s00394-020-02372-4

Hewison M., Burke F., Evans K.N., Lammas D.A., Sansom D.M., Liu P., Modlin R.L., Adams J.S., 2007. Extra-renal 25-hydroxyvitamin D3-1alpha-hydroxylase in human health and disease. J. Steroid Biochem. Mol. Biol. 103(3-5), 316-321. https://doi.org/10.1016/j.jsbmb.2006.12.078

Holick, M.F., 2015. Vitamin D update 2015: What we need to know about its health benefits and potential for toxicity. Standardy medyczne pediatria $12.5,759-763$.

Jones G., Strugnell S.A., DeLuca H.F., 1998. Current understanding of the molecular actions of vitamin D. Physiol Rev. 78(4), 1193-1231. https://doi.org/10.1152/physrev.1998.78.4.1193

Kaur P., Mishra S.K., Mithal A. 2015. Vitamin D toxicity resulting from overzealous correction of vitamin D deficiency. Clin Endocrinol. (Oxf). 83(3), 327-331. https://doi.org/10.1111/cen.12836 
Kawashima H., Torikai S., Kurokawa K., 1981. Localization of 25-hydroxyvitamin D3 1 alphahydroxylase and 24-hydroxylase along the rat nephron. Proc. Natl. Acad. Sci. USA. 78(2), 1199-203. https://doi.org/10.1073/pnas.78.2.1199

Keum N., Lee D.H., Greenwood D.C., Manson J.E., Giovannucci E., 2019. Vitamin D supplementation and total cancer incidence and mortality: a meta-analysis of randomized controlled trials. Ann Oncol. 1, 30(5), 733-743. https://doi.org/10.1093/annonc/mdz059

Kulda V. 2012. Metabolizmus vitaminu D [Vitamin D metabolism]. Vnitr. Lek. 58(5), 400-404.

MacLaughlin J., Holick M.F., 1985. Aging decreases the capacity of human skin to produce vitamin D3. J. Clin. Invest. 76(4), 1536 -1538. https://doi.org/10.1172/JCI112134

McCullough M.L., Zoltick E.S., Weinstein S.J., Fedirko V., Wang M., Cook N.R., Eliassen A.H., Zeleniuch-Jacquotte A., Agnoli C., Albanes D., Barnett M.J., Buring J.E., Campbell P.T., Clendenen T.V., Freedman N.D., Gapstur S.M., Giovannucci E.L., Goodman G.G., Haiman C.A., Ho G.Y.F., Horst R.L., Hou T., Huang W.Y., Jenab M., Jones M.E., Joshu C.E., Krogh V., Lee I.M., Lee J.E., Männistö S., Le Marchand L., Mondul A.M., Neuhouser M.L., Platz E.A., Purdue M.P., Riboli E., Robsahm T.E., Rohan T.E., Sasazuki S., Schoemaker M.J., Sieri S., Stampfer M.J., Swerdlow A.J., Thomson C.A., Tretli S., Tsugane S., Ursin G., Visvanathan K., White K.K., Wu K., Yaun S.S., Zhang X., Willett W.C., Gail M.H., Ziegler R.G., Smith-Warner S.A., 2019. Circulating vitamin $\mathrm{D}$ and colorectal cancer risk: An international pooling project of 17 cohorts. J. Natl. Cancer Inst. 1, 111(2), 158-169. https://doi.org/10.1093/jnci/djy087. medRxiv 2020.04.24.20075838; https://doi.org/10.1101/2020.04.24.20075838

Meltzer D.O., Best T.J., Zhang H., Vokes T., Arora V., Solway J., 2020. Association of vitamin D status and other clinical characteristics with COVID-19 test results. JAMA Netw. Open. 1, 3(9), e2019722. https://doi.org/10.1001/jamanetworkopen.2020.19722

Nykjaer A., Dragun D., Walther D., Vorum H., Jacobsen C., Herz J., Melsen F., Christensen E.I., Willnow T.E., 1999. An endocytic pathway essential for renal uptake and activation of the steroid 25-(OH) vitamin $\mathrm{D}_{3}$. Cell 19, 96(4), 507-515. https://doi.org/10.1016/s00928674(00)80655-8.

Nykjaer A., Fyfe J.C., Kozyraki R., Leheste J.R., Jacobsen C., Nielsen M.S., Verroust P.J., Aminoff M., de la Chapelle A., Moestrup S.K., Ray R., Gliemann J., Willnow T.E., Christensen E.I., 2001. Cubilin dysfunction causes abnormal metabolism of the steroid hormone $25(\mathrm{OH})$ vitamin D(3). Proc. Natl. Acad. Sci. USA, 20, 98(24), 13895-13900. https://doi.org/10.1073/pnas.241516998

Ong J.S., Cuellar-Partida G., Lu Y., Australian Ovarian Cancer Study, Fasching P.A., Hein A., Burghaus S., Beckmann M.W., Lambrechts D., Van Nieuwenhuysen E., Vergote I., Vanderstichele A., Doherty A.J., Rossing A.M., Chang-Claude J., Eilber U., Rudolph A., WangGohrke S., Goodman M.T., Bogdanova N., Dörk T., Dürst M., Hillemanns P., Runnebaum I.B., Antonenkova N., Butzow R., Leminen A., Nevanlinna H., Pelttari L.M., Edwards R.P., Kelley J.L., Modugno F., Moysich K.B., Ness R.B., Cannioto R., Høgdall E., Høgdall C.K., Jensen A., Giles G.G., Bruinsma F., Kjaer S.K., Hildebrandt M.A., Liang D., Lu K.H., Wu X., Bisogna M., Dao F., Levine D.A., Cramer D.W., Terry K.L., Tworoger S.S., Stampfer M., Missmer S., Bjorge L., Salvesen H.B., Kopperud R.K., Bischof K., Aben K.K., Kiemeney L.A., Massuger L.F., Brooks-Wilson A., Olson S.H., McGuire V., Rothstein J.H., Sieh W., Whittemore A.S., Cook L.S., Le N.D., Gilks C.B., Gronwald J., Jakubowska A., Lubiński J., Kluz T., Song H., Tyrer J.P., Wentzensen N., Brinton L., Trabert B., Lissowska J., McLaughlin J.R., Narod S.A., Phelan C., Anton-Culver H., Ziogas A., Eccles D., Campbell I., Gayther S.A., Gentry-Maharaj A., Menon U., Ramus S.J., Wu A.H., Dansonka-Mieszkowska A., Kupryjanczyk J., Timorek A., Szafron L., Cunningham J.M., Fridley B.L., Winham S.J., Bandera E.V., Poole E.M., Morgan T.K., Risch H.A., Goode E.L., Schildkraut J.M., Pearce C.L., Berchuck A., Pharoah P.D., Chenevix-Trench G., Gharahkhani P., Neale R.E., Webb P.M., MacGregor S., 2016 Association of vitamin D levels and risk of ovarian cancer: a Mendelian randomization study. Int. J. Epidemiol. 45(5), 1619-1630. https://doi.org/10.1093/ije/dyw207

Pludowski P., Holick M., Grant W., Konstantynowicz J., Mascarenhas M., Haq A., Povoroznyuk V., Balatska N., Barbosa A., Karonova T., Rudenka E., Misiorowski W., Zakharova I., Rudenka 
A., Łukaszkiewicz J., Marcinowska-Suchowierska E., Łaszcz N., Abramowicz P., Bhattoa H., Wimalawansa S., 2018. Vitamin D supplementation guidelines, J. Steroid Biochem. Mol. Biol., $175,125-135$.

Płudowski P., Karczmarewicz E., Bayer M., Carter G., Chlebna-Sokół D., Czech-Kowalska J., Dębski R., Decsi T., Dobrzańska A., Franek E., Gluszko P., Grant W., Holick M., Yankovskaya L., Konstantynowicz J., Książyk J., Księżopolska-Orłowska K., Lewiński A., Litwin M., Lohner S., Lorenc R., Łukaszkiewicz J., Marcinowska-Suchowierska E., Milewicz A., Misiorowski W., Nowicki M., Povoroznyuk V., Rozentryt P., Rudenka E., Shoenfeld Y., Socha P., Solnica B., Szalecki M., Tałałaj M., Varbiro Sz., Żmijewski M. 2013. Practical guidelines for the supplementation of vitamin D and the treatment of deficits in Central Europe - recommended vitamin D intakes in the general population and groups at risk of vitamin D deficiency. Endokrynol. Pol. 64(4), 319-327.

Schmid A., Walther B., 2013. Natural vitamin D content in animal products. Adv. Nutr., 4(4), 453-462.

Scragg R., Khaw K.T., Toop L., Sluyter J., Lawes C.M.M., Waayer D., Giovannucci E., Camargo C.A. Jr., 2018. Monthly high-dose vitamin D supplementation and cancer risk: a post hoc analysis of the vitamin D assessment randomized clinical trial. JAMA Oncol. 1, 4(11), e182178. https://doi.org/10.1001/jamaoncol.2018.2178

Terushkin V., Bender A., Psaty E.L., Engelsen O., Wang S.Q., Halpern A.C., 2010. Estimated equivalency of vitamin D production from natural sun exposure versus oral vitamin D supplementation across seasons at two US latitudes. J. Am. Acad. Dermatol., 62(6), 929, e1-9. https://doi.org/10.1016/j.jaad.2009.07.028

Theodoratou E., Tzoulaki I., Zgaga L., Ioannidis J.P., 2014. Vitamin D and multiple health outcomes: umbrella review of systematic reviews and meta-analyses of observational studies and randomised trials. BMJ. 1(348), g2035. https://doi.org/10.1136/bmj.g2035

Valcour A., Blocki F., Hawkins D.M., Rao S.D., 2012. Effects of age and serum 25-OH-vitamin D on serum parathyroid hormone levels. J. Clin. Endocrinol. Metab. 97(11), 3989-3995. https://doi.org/10.1210/jc.2012-2276

Visser M., Deeg D.J., Lips P., 2003. Longitudinal aging study Amsterdam. Low vitamin D and high parathyroid hormone levels as determinants of loss of muscle strength and muscle mass (sarcopenia): the longitudinal aging study Amsterdam. J. Clin. Endocrinol. Metab. 88(12), 57665772 .

Wicherts I.S., van Schoor N.M., Boeke A.J., Visser M., Deeg D.J., Smit J., Knol D.L., Lips P. 2007. Vitamin D status predicts physical performance and its decline in older persons. J. Clin. Endocrinol. Metab. 92(6), 2058-2065. https://doi.org/10.1210/jc.2006-1525

Zipitis C.S., Akobeng A.K., 2008. Vitamin D supplementation in early childhood and risk of type 1 diabetes: a systematic review and meta-analysis. Arch. Dis. Child. 93(6):512-517. https://doi.org/10.1136/adc.2007.128579 
Rafał Oleszczuk ${ }^{2}$, Agnieszka M. Grzebalska ${ }^{1}$, Michał Smyka², Jakub Mendocha ${ }^{2}$

\section{Witamina D w przewlekłej chorobie nerek}

Vitamin D in chronic kidney disease

Od co najmniej 20 lat witamina D cieszy się niesłabnącym zainteresowaniem. Oprócz klasycznego wpływu na regulację gospodarki wapniowo-fosforanowej i metabolizm tkanki kostnej witamina D ma liczne dodatkowe, pozytywne działania. Nazywane są one efektami plejotropowymi [Souberbielle i in. 2010, Pludowski i in. 2013, Płudowski i in. 2016, Franca Gois i in. 2018, Amrein in. 2020]. Dzięki licznym pracom badawczym odkryto takie efekty plejotropowe jej działania, jak wpływ na choroby nowotworowe, sercowo-naczyniowe, cukrzycę, rozrodczość i wiele innych [Souberbielle i in. 2010, Pludowski i in. 2013, Sajkowska i in. 2014, Colonese i in. 2015, Wiśniewski i in. 2016, Płudowski i in. 2016, Franca Gois i in. 2018, Amrein in. 2020].

Niedobór witaminy D w populacji ogólnej jest zjawiskiem powszechnym i stanowi ważny problem dla ochrony zdrowia [Holick 2007, Holick 2008, Inda Filho i in. 2013, Franca Gois i in. 2018, Amrein in. 2020]. Dane szacunkowe mówią, że około 30-50\% ludzi dotkniętych jest niedoborem witaminy D [Nakashima i in. 2016]. Często niedobór witaminy D jest wynikiem przewlekłej choroby nerek (PChN), bo to w nerkach powstaje najbardziej aktywna postać witaminy D - cholekalcyferol. Przewlekła choroba nerek jest poważnym schorzeniem o wieloletnim przebiegu, prowadzącym ostatecznie do całkowitej niewydolności narządu i w konsekwencji konieczności rozpoczęcia leczenia nerkozastępczego. Koszty leczenia PChN stanowią znaczące obciążenie systemów zdrowia [Inda Filho i in. 2013, Mariana i in. 2019]. Prowadzone od lat badania u chorych z PChN potwierdzają, że znaczna ich część cierpi na deficyt witaminy D [Galunska i in. 2015, Krause i in. 2016, Goldsmith 2016, Franca Gois i in. 2018, Restrepo Valencia CA 2019]. Następstwem niedoboru witaminy D w tej części społeczeństwa są m.in.: rozwój wtórnej nadczynności przytarczyc, powikłania kostne, zwiększenie ryzyka śmiertelności z powodów sercowych [Fiedler i in. 2011, Inda Filho i in. 2013].

Poniższa praca stanowi krótki przegląd piśmiennictwa dotyczącego niedoboru witaminy D u chorych cierpiących na przewlekłą chorobę nerek.

\section{Dzialanie witaminy D}

Choć powszechnie mówi się o „witaminie D”, w rzeczywistości jest to cała grupa związków rozpuszczalnych w tłuszczu. Ich prekursory pochodzą z dwóch źródeł: poży-

\footnotetext{
${ }^{1}$ Uniwersytet Medyczny w Lublinie, Wydział lekarski, Katedra i Klinika Nefrologii Uniwersytetu Medycznego w Lublinie

${ }^{2}$ Uniwersytet Medyczny w Lublinie, Wydział lekarski, Studenckie Koło Naukowe przy Katedrze i Klinice Nefrologii Uniwersytetu Medycznego w Lublinie, rafal.ole@gmail.com
} 
wienia lub skóry [Sajkowska i in. 2014]. Ocenia się, że z pożywieniem otrzymujemy zaledwie 10-20\% witaminy D. Większość, bo ponad $80 \%$ jest syntezowana w skórze pod wpływem promieniowania ultrafioletowego [Holick MF 2008, Nan Zhu i in. 2015, Krause i in. 2016, Wiśniewski i in. 2016]. Prekursory witaminy D po związaniu z białkiem wiążącym witaminę D są transportowane do wątroby, gdzie ulegają hydroksylacji do 25(OH)-D hydroksycholekalcyferolu. Dalsza hydroksylacja odbywa się w nerkach i w ten sposób powstaje najbardziej aktywna postać witaminy D 1,25-dihydroksycholekalcyferol $\left(1,25(\mathrm{OH})_{2} \mathrm{D}\right)$, zwana kalcytriolem [Sajkowska i in. 2014, Nan Zhu i in. 2015].

Zasadniczą rolą witaminy D jest utrzymanie równowagi wapniowo-fosforanowej, udział w budowie kośćca i jego prawidłowym działaniu [Amrein in. 2020]. Działanie to jest dobrze poznane. Od lat zainteresowanie badaczy skupia się jednak na efektach plejotropowych witaminy D [Colonese i in. 2015, Płudowski i in. 2016, Szeja 2017, Franca Gois i in. 2018, Amrein in. 2020]. Jest ich wiele i są one bardzo różnorodne. I tak znany jest efekt działania witaminy D na układ immunologiczny: zwiększając liczbę limfocytów i syntezę cytokin przeciwzapalnych, bierze ona udział w odpowiedzi organizmu na czynniki infekcyjne [Souberbielle i in. 2010, Pludowski i in. 2013, Nan Zhu i in. 2015]. Udokumentowano, że witamina D wpływa na płodność kobiet z zespołem policystycznych jajników i zwiększa wydzielanie insuliny [Pludowski i in. 2013, Colonese i in. 2015]. Stwierdzono również, że w stężeniu 30-40 ng/ml witamina D redukuje ogólne ryzyko występowania nowotworów [Grant 2016]. Nadto potwierdzono, że zmniejsza prawdopodobieństwo rozwoju raka jelita grubego i raka piersi [Grant 2015a, 2016b].

Tak liczne działania pozakostne witaminy D są możliwe dzięki obecności jej receptora (and. vitamin D receptor - VDR) w większości komórek ludzkiego ciała. Ocenia się, że witamina D ma wpływ na ok 3\% genomu ludzkiego [Nan Zhu i in. 2015, Szeja 2017].

Wszystkie wyżej wymienione efekty plejotropowe, czyli dodatkowe działania witaminy D, są nie do przecenienia. Warunkiem ich występowania jest jednakże prawidłowe stężenie witaminy D w surowicy krwi, które wynosi minimum $30 \mathrm{ng} / \mathrm{ml}$ [Sajkowska i in. 2014, Nan Zhu i in. 2015, Płudowski i in. 2016, Wiśniewski i in. 2016].

\section{Przewlekła choroba nerek}

Nerki uczestniczą w usuwaniu z organizmu nadmiaru wody, elektrolitów i toksycznych produktów przemiany materii. Jest to ich funkcja zewnątrzwydzielnicza (wydalnicza). Dzięki niej powstaje mocz i możliwe jest utrzymanie równowagi wewnętrznej organizmu, czyli homeostazy. Drugą funkcją nerek jest funkcja wewnątrzwydzielnicza, na którą składa się m.in. produkcja reniny, urokinazy, erytropoetyny i witaminy D.

Uszkodzenie struktury i/lub funkcji nerek, które utrzymuje się ponad 3 miesiące i przebiega ze zmniejszeniem wielkości filtracji kłębuszkowej (ang. glomerular filtration rate - GFR) nazywane jest przewlekłą chorobą nerek (PChN). Główne przyczyny PChN to cukrzyca, nadciśnienie, przewlekłe zapalenie kłębuszków nerkowych, przewlekłe odmiedniczkowe zapalenie nerek, przewlekłe stosowanie leków przeciwzapalnych, choroby autoimmunologiczne, wielotorbielowatość nerek, choroba Alporta, wrodzone wady rozwojowe i wielokrotne ostre uszkodzenia nerek. W zależności od wielkości GFR wyróżnia się pięć stadiów PChN [Gajewski 2014, Ammirati 2020]: 
Stadium 1 - prawidłowa wielkość GFR $\geq 90 \mathrm{ml} / \mathrm{min} / 1,73 \mathrm{~m}^{2}$,

Stadium 2 - GFR w granicach $89-60 \mathrm{ml} / \mathrm{min} / 1,73 \mathrm{~m}^{2}$,

Stadium 3 - GFR w granicach $59-30 \mathrm{ml} / \mathrm{min} / 1,73 \mathrm{~m}^{2}$,

Stadium 4 - GFR w granicach $29-15 \mathrm{ml} / \mathrm{min} / 1,73 \mathrm{~m}^{2}$,

Stadium 5 - GFR $<15 \mathrm{ml} / \mathrm{min} / 1,73 \mathrm{~m}^{2}$.

PChN jest bardzo rozpowszechniona, ponieważ w Polsce szacuje się, że występuje u $11 \%$ społeczeństwa. Ponadto wiąże się z wyższym ryzykiem chorób układu krążenia, ich trudnego przebiegu i zgonu. W rzeczywistości globalne dane z 2013 r. pokazały, że zmniejszenie GFR było związane z 4\% zgonów na świecie (2,2 mln). Ponad połowa tych zgonów była spowodowana przyczynami sercowo-naczyniowymi, a u $0,96 \mathrm{mln}$ schyłkową niewydolnością nerek. Na świecie śmiertelność podczas dializy utrzymuje się u ok. 19,9\% pacjentów [Rutkowski 2013, Ammirati 2020]

W miarę postępu PChN i pogorszenia funkcji nerek u chorych obserwuje się zmniejszenie produkcji witaminy $\mathrm{D}$. Aby utrzymać prawidłowe stężenie wapnia w surowicy, przytarczyce produkują wówczas zwiększoną ilość parathormonu (PTH) i w efekcie rozwija się wtórna nadczynność przytarczyc [Restrepo Valencia i Aguirre Arango 2019].

\section{Ocena stężenia witaminy D u pacjentów z PChN i dializowanych}

Częstość występowania niedoboru 25(OH)D jest większa u osób z PChN niż w populacji ogólnej i pogarsza się wraz z progresją choroby. Uważa się, że najbardziej wiarygodnym biomarkerem do oceny stanu witaminy D jest krążący we krwi $25(\mathrm{OH}) \mathrm{D}$, ponieważ wykazuje on długi okres półtrwania i odzwierciedla zarówno endo-, jak i egzogenną witaminę D. Dostępne są różne rodzaje testów do pomiaru stężenia $25(\mathrm{OH}) \mathrm{D}$. Złotym standardem jest chromatografia cieczowa, ale wysokie koszty i specjalne wymagania sprzętowe ograniczają jej użycie. W porównaniu z nią szeroko stosowane są testy immunologiczne. Należy jednak zauważyć, że nawet po standaryzacji u pacjentów z PChN obserwuje się istotne odchylenie wyników metody referencyjnej. Nie ma jednakowego zdania co do prawidłowych wartości $25(\mathrm{OH}) \mathrm{D}$ w populacji ogólnej, ani u pacjentów z przewlekłą chorobą nerek, ani pacjentów dializowanych. Jeśli chodzi o populację ogólną - niedawny raport Amerykańskiego Instytutu Medycyny zalecił utrzymanie stężenia witaminy D w surowicy od 20 do $50 \mathrm{ng} / \mathrm{ml}$, podczas gdy Amerykańskie Towarzystwo Endokrynologiczne zaleca, aby stężenie $25(\mathrm{OH}) \mathrm{D}$ mniejsze niż $20 \mathrm{ng} / \mathrm{ml}$ oraz stężenia od 21 do $29 \mathrm{ng} / \mathrm{ml}$ określać jako niedobór witaminy D, a wartości większe niż $30 \mathrm{ng} / \mathrm{ml}$ uważać za prawidłowe. Pomimo tego powstaje pytanie, czy wartości uznane za „normalne" dla populacji ogólnej można stosować u pacjentów z przewlekłą chorobą nerek i pacjentów dializowanych? Dotychczas nie zostało to jeszcze wyjaśnione. Różne międzynarodowe wytyczne przedstawiają niejednorodne definicje niedoboru 25(OH)D. Wytyczne Kidney Disease Outcome Quality Initiative z 2003 r. zalecają stężenie $\geq 30$ ng/ml, aby zapobiec wtórnej nadczynności przytarczyc i zmniejszyć częstość złamań u pacjentów z PChN w stadium 3. i 4. Niemniej jednak opublikowane badanie przekrojowe na dużej kohorcie pacjentów w stadium 1-5 PChN nie wykazało dowodów na zmniejszający wpływ 25(OH)D na stężenie PTH. Takie wyniki sugerują stosowanie większego docelowego stężenia witaminy D u osób z PChN bez dodatkowego ryzyka hiperkalcemii i hiperfosfatemii. Włoska grupa robocza „Pierwiastki śladowe i metabolizm minerałów” 
Włoskiego Towarzystwa Nefrologicznego stwierdziła, że $30 \mathrm{ng} / \mathrm{ml}$ wydaje się rozsądnym celem w zapobieganiu i leczeniu wtórnej nadczynności przytarczyc u pacjentów z PChN [Capelli i in. 2020].

\section{Skutki niedoboru witaminy D u pacjentów z PChN}

Według publikacji The Workshop Consensus for Vitamin D Nutritional Guidelines z roku 2010 ponad $50 \%$ ogólnej populacji osób starszych cierpi na niedobór witaminy D [Henry $i$ in. 2010]. Niedobór witaminy D u chorych na PChN jest również powszechny i obecny już we wczesnych jej stadiach. Potwierdzono, że związane z nim zaburzenia gospodarki wapniowo-fosforanowej występują już w całym stadium trzecim [Goldsmith 2016, Franca Gois i in. 2018, Mariana i in. 2019, Restrepo Valencia 2019]. O stwierdzanym obniżeniu stężenia witaminy D już nawet w drugim stadium PChN donoszą Gonzales i LaClair [González i in. 2004, Henry i in. 2010]. Im wyższe stadium przewlekłej choroby nerek, tym niedobór powszechniejszy. W zaawansowanych stadiach $\mathrm{PChN}$ niedobór witaminy D dotyka ponad $60 \%$ pacjentów, a może dochodzić nawet do $90 \%$ [LaClair i in. 2005, Galunska i in. 2015]. Nawet w słonecznej Brazylii niedobór witaminy D w populacji niedializowanych chorych z PCHN w stadiach od 2 do 5 sięga 39,6\% [Cuppari i in. 2008]. Jednoośrodkowe badanie Matias i in. [2010] podaje, że 80\% pacjentów $\mathrm{z}$ niewydolnością nerek, u których wykonywano hemodializy, miało niedobór 25(OH)D-ergocholekalcyferolu, a niedobór $1,25(\mathrm{OH})_{2}$ D-cholekalcyferolu, czyli kalcytriolu, stwierdzono u aż 95\% chorych!

Wyniki licznych badań wskazują na to, że niedobór witaminy D wiąże się generalnie ze zwiększonym ryzykiem rozwoju nowotworów, infekcji, chorób układu sercowonaczyniowego, układu odpornościowego, a nawet cukrzycy typu 2 [de Boer i in. 2007, Fiedler i in. 2011, Pilz i in. 2011 a, 2011 b, Inda Filho i in. 2013, Chonchol i in. 2016].

Potwierdzono także związek między niedoborem witaminy D i tradycyjnymi czynnikami ryzyka chorób sercowo-naczyniowych takimi jak nadciśnienie czy insulinooporność [Forman i in. 2007, Pittas i in. 2006]. Ponadto niedobór witaminy D jest związany z większą częstością występowania otyłości i złamań [Chonchol i in. 2016]. Istnieją potwierdzone doświadczalnie dowody na związek między niedoborem witaminy D a zwiększonym ryzykiem ogólnej śmiertelności u pacjentów cierpiących na PChN, i to niezależnie od stadium jej zaawansowania [Teng i in. 2005, Melamed i in. 2006, Wolf $i$ in. 2007, Shoben i in. 2008, Ravani i in. 2009, Barreto i in. 2009, Fiedler i in. 2011, Pilz i in. 2011 a, 2011 b]. Ponadto udokumentowano, że niedobór witaminy D przyspiesza progresję PChN [Franca Gois i in. 2018].

\section{Leczenie niedoboru u pacjentów z PChN}

Odnosząc się do wskazań dietetycznych w populacji ogólnej, Institute of Medicine z USA i Kanady początkowo zalecił, aby dorośli w wieku do 70 lat otrzymywali $600 \mathrm{IU} /$ dobę witaminy D, podczas gdy dorośli w wieku 71 lat i starsi - $800 \mathrm{IU} /$ dobę. Zalecenia te obejmują potrzeby więcej niż $97,5 \%$ populacji i zakładają minimalną lub zerową ekspozycję na słońce, zapewniając tym samym dalsze bezpieczeństwo osobom $z$ mniejszą endogenną syntezą. Natomiast aktualne wytyczne sugerują, żeby pacjenci z 
przewlekłą chorobą nerek w stadium 1-5 stosowali suplementację, wykorzystując strategie zalecane dla populacji ogólnej. Jednak dla każdej populacji wytyczne są różne ze względu na m.in. kolor skóry czy szerokość geograficzną. Eksperci Kidney Disease Outcome Quality (KDOQI) sugerują przyjmowanie 1000-2000 IU/dobę witaminy D. Jednak przyznają również, że pacjenci z $\mathrm{PChN}$ mogą wymagać bardziej agresywnego planu terapeutycznego. National Institute for Clinical Excellence (NICE) w Wielkiej Brytanii twierdzi, że osoby mające więcej niż 65 lat, które nie są narażone na dużą ekspozycję na słońce, powinny przyjmować 400 IU witaminy D dziennie. W Australii i Nowej Zelandii, Kidney Health Australia-Caring for Australasians with Renal Impairment (KHA-CARI) nie sugeruje żadnej konkretnej dawki w przypadku pacjentów z PChN [Franca Gois i in. 2018].

\section{Pozytywy suplementacji witaminy D u chorych z PChN}

Wobec powyższych danych nie dziwi zainteresowanie efektami suplementacji witaminy D wśród chorych na PChN. Od z górą 3 dekad preparaty witaminy D są rutynowo stosowane w praktyce klinicznej, aby zapobiegać lub zmniejszać nasilenia wtórnej nadczynności przytarczyc i tym samym poprawiać metabolizm kostny u chorych z PChN [Goldsmith 2016, Mariana i in. 2019]. Ponieważ zmniejszenie stężenia witaminy D obserwuje się już u chorych w stadium drugim PChN, istnieją sugestie, by stężnie witaminy D oznaczać u wszystkich pacjentów z GFR poniżej $60 \mathrm{ml} / \mathrm{min} / 1,73 \mathrm{~m}^{2}$ [Restrepo Valencia CA 2019].

Znaczna część badaczy sugeruje, że zasady wyrównywania niedoborów witaminy D u chorych z PChN powinny opierać się na analogicznych założeniach, jakie są stosowane w ogólnej populacji [Pilz i in. 2011 a, 2011 b, Płudowski i in. 2013, Szeja 2017, KDIGO 2017, Rusińska i in. 2018, National Kidney Foundation 2018, Chan i in. 2018, Amrein in. 2020].

Eksperci Kidney Disease Outcome Quality (KDOQI) oraz Kidney Disease Global Outcomes (KDIGO) zalecają, by kontrolować stężenie witaminy D u chorych z PChN i w razie niskiej jej zawartości - suplementować [KDIGO 2017, National Kidney Foundation 2018].

Nadal nie ma jednak ,twardych” zaleceń postępowania u chorych z PChN [Mariana i in. 2019]. Dzieje się tak dlatego, że suplementacja witaminy D w PChN jest zagadnieniem trudnym klinicznie i wymaga szczególnej ostrożności, zwłaszcza u tych pacjentów, którzy mają dodatkowo suplementowany wapń lub przyjmują preparaty ograniczające wchłanianie fosforanów z przewodu pokarmowego [Franca Gois i in. 2018].

Równoczasowa suplementacja witaminy D i preparatów wapnia może spowodować przekroczenie wielkości iloczynu CaxP > 55 i wywołać kalcyfikację metastatyczną, na którą składają się zwapnienia tkanek miękkich okołostawowych oraz zwapnienia naczyń krwionośnych, w tym naczyń wieńcowych i zastawek serca. Badanie Samaana i in., przeprowadzone co prawda na niewielkiej grupie (80 chorych z GFR w granicach $15-60 \mathrm{ml} / \mathrm{min} / 1,73 \mathrm{~m}^{2}$ ) nie potwierdziło by suplementacja witaminy $\mathrm{D}$ u tych pacjentów osłabiała progresję kalcyfikacji naczyń krwionośnych [Samaan i in. 2019]. Badanie de Boer i in. [2009] wykazało znaczący związek między małym stężeniem witaminy D a rozwojem kalcyfikacji naczyniowej u chorych na PChN. Podobne wyniki uzyskano u chorych z PChN dializowanych i niedializowanych w innych badaniach [García-Canton $i$ in. 2011, Wang $i$ in. 2015]. 
Jak już nadmieniono powyżej niedobór witaminy $\mathrm{D}$ u chorych z PChN wiedzie do zwiększonego ryzyka zapadalności i śmiertelności z powodów sercowo-naczyniowych [de Boer i in. 2007]. Metaanaliza dwudziestu badań obserwacyjnych przeprowadzona przez Zhenga i in. [2013] dowiodła, że suplementacja witaminy D u chorych z PChN (zarówno wymagających, jak i niewymagających dializoterapii) zmniejszała ogólne ryzyko śmiertelności z powodów sercowo-naczyniowych. Co więcej uważa się, że im wcześniej zostaną podjęte działania mające na celu wyrównanie niedoboru, tym efekt będzie lepszy: nie tylko ograniczony zostanie rozwój wtórnej nadczynności przytarczyc i zmian kostnych, ale również znacznie zmniejszone zostanie prawdopodobieństwo rozwoju zaburzeń sercowo-naczyniowych [Goldsmith 2016]. Dlatego obecnie polscy badacze sugerują, by suplementować witaminę $\mathrm{D}$ u pacjentów znajdujących się nawet w początkowych stadiach PChN, u których wykryto niedobór witaminy D z towarzyszącą nadczynnością wtórną przytarczyc [Staszków i in. 2014].

Ponieważ w wielu chorobach wiodących do PChN obserwuje się albuminurię lub białkomocz, naczelnym celem postępowania nefrologów jest dążenie do redukcji białkomoczu. Udowodniono, że witamina D lub kalcymimetyki jak parykalcytol mogą mieć pozytywny wpływ na redukcję albuminurii [de Zeeuw i in. 2010, Kim i in. 2011, Molina i in. 2014, Nan Zhu i in. 2015,]. Tym samym można mówić o „nefroprotekcyjnym” efekcie działania witaminy D [Nan Zhu i in. 2015]. Niestety działanie witaminy D w tym zakresie wydaje się niejednoznaczne, bowiem z drugiej strony istnieją doniesienia mówiące, że suplementacja witaminy D może przyspieszać progresję PChN [Makibayashi i in. 2001].

Liczne badania dotyczące wpływu suplementacji witaminy D na układ sercowonaczyniowy poskutkowały ciekawymi wynikami. Od dawna wiadomo, że suplementowanie cholekalciferolem normalizuje wartości PTH u pacjentów z PChN, ostatnio zaś w badaniach u chorych dializowanych obserwowano redukcję przerostu lewej komory i obniżenie BNP (ang. B-type natriuretic peptide - mózgowy peptyd natriuretyczny, marker niewydolności serca) [Alvarez $i$ in. 2012, Bucharles i in. 2012]. O zmniejszeniu stężenia BNP w wyniku suplementacji witaminy D donosi też Matias i in. [Matias i in. 2010]. Ponadto są dowody na korzystny wpływ wyrównania stężenia witaminy D na nadciśnienie tętnicze [Nan Zhu i in. 2015]. W świetle wyżej wymienionych faktów zasadne jest uzupełnianie deficytu witaminy D u chorych z PChN. Kwestią dalszej dyskusji pozostaje, jaką formę witaminy D stosować? Czy powinien być to ergokalcyferol, czy cholekalcyferol? [Armas i in. 2004, Goldsmith 2016]. Kwestią dyskusyjną pozostaje też droga podania witaminy D: czy powinno się podawać formy dostępne doustnie czy dożylnie? Ostatecznie najnowsza metaanaliza wykazuje, że niezależnie od drogi podania, częstości stosowania i wielkości jednorazowej dawki, to cholekalcyferol bardziej zwiększa stężenie witaminy D w surowicy [Armas i in. 2004, Tripkovic i in. 2012] .

Oprócz witaminy D obecnie coraz powszechniej stosuje się kalcimimetyki, np.: parikalcytol. Jak wykazały badania Zhenga i in. [2013] podanie parikalcytolu miało nawet nieznacznie korzystniejszy wpływ na zmniejszenie śmiertelności (przeżycie) wśród chorych na PChN niż suplementacja kalcytriolu.

\section{Podsumowanie}

Witamina D jest odpowiedzialna za gospodarkę wapniowo-fosforanową i metabolizm kostny. Ma również liczne efekty plejotropowe, w tym modyfikuje odporność, 
zmniejsza występowanie nowotworów, wpływa na płodność, zmniejsza ogólną śmiertelność z przyczyn sercowo-naczyniowych. U chorych na PChN, u których powszechny jest deficyt witaminy D i wtórne doń zaburzenia metabolizmu kostnego oraz wtórna nadczynność przytarczyc, obserwujemy, że niskie stężenie witaminy D skutkuje też szybszą progresją do niewydolności, większym ryzykiem wystąpienia powikłań sercowo-naczyniowych i większą śmiertelnością. Odwrotnie suplementacja witaminy D przynosi chorym na PChN liczne korzyści: poza poprawą metabolizmu kostnego powoduje również zmniejszenie przerostu lewej komory mięśnia sercowego, białkomoczu, nadciśnienia, śmiertelności. Aktualne zalecenia nie pozostawiają wątpliwości co do konieczności suplementowania witaminy D u chorych na PChN, u których występuje jej niedobór. Kwestią dyskusyjną pozostaje jednak, jaką postać witaminy D suplementować, jak często i jaką drogą ją podawać. Niektórzy badacze sugerują potrzebę suplementowania witaminy D tylko u tych chorych na PChN, u których obok niskiego stężenia witaminy D stwierdza się jednoczasowo cechy wtórnej nadczynności przytarczyc. Podkreśla się też konieczność monitorowania stężenia samej witaminy $\mathrm{D}$, jak również wapnia i fosforu w trakcie terapii. Ostatecznie leczenie preparatami witaminy D zależne jest od wnikliwości i doświadczenia lekarza klinicysty.

\section{Bibliografia}

Alvarez J.A., Law J., Coakley K.E., Zughaier S.M., Hao L., Shahid Salles K., Wasse H., Gutiérrez O.M., Ziegler T.R., Tangpricha V., 2012 High-dose cholecalciferol reduces parathyroid hormone in patients with early chronic kidney disease: a pilot, randomized, double-blind, placebocontrolled trial. Am. J. Clin. Nutr. 96(3), 672-679. https://doi.org/10.3945/ajcn.112.040642.

Ammirati A.L., 2020. Chronic kidney disease. Rev. Assoc. Med. Bras. 66(Suppl 1), s03-s09. https://doi.org/10.1590/1806-9282.66.S1.3

Amrein K., Scherkl M., Hoffmann M., Neuwersch-Sommeregger S., Köstenberger M., Tmava Berisha A., Martucci G., Pilz S., Malle O., 2020. Vitamin D deficiency 2.0: an update on the current status worldwide. Eur. J. Clin. Nutr. 74(11), 1498-1513. https://doi.org/10.1038/s41430-0200558-y

Armas L.A., Hollis B.W., Heaney R.P., 2004. Vitamin D2 is much less effective than vitamin D3 in humans. J. Clin. Endocrinol. Metab. 89(11), 5387-91. https://doi.org/10.1210/jc.2004-0360

Barreto D.V., Barreto F.C., Liabeuf S, i in. 2009. Vitamin D affects survival independently of vascular calcification in chronic kidney disease. Clin. J. Am. Soc. Nephrol. 4(6),1128-35. doi:10.2215/CJN.00260109

Bucharles S., Barberato S.H., Stinghen A.E.M., Gruber B., Piekala L., Dambiski A.C., Custodio M.R., Pecoits-Filho R., 2012. Impact of cholecalciferol treatment on biomarkers of inflammation and myocardial structure in hemodialysis patients without hyperparathyroidism. J. Ren. Nutr. 22(2), 284-291. https://doi.org/10.1053/j.jrn.2011.07.001

Capelli I., Cianciolo G., Gasperoni L., Galassi A., Ciceri P., Cozzolino M., 2020. Nutritional vitamin D in CKD: Should we measure? Should we treat?. Clin. Chimica Acta, 186-197. https://doi.org/10.1016/j.cca.2019.11.010

Cardoso M.P., Pereira L.A.L., 2019. Native vitamin D in pre-dialysis chronic kidney disease. Nefrologia 39(1), 18-28.

Chan A.M., Johnson D. 2018. Vitamin D therapy (supplementation) in early chronic kidney disease. The CARI guidelines. http://www.cari.org.au/CKD/CKD\%20early/Vitamin_D_Therapy_ECKD.pdf [dostęp 24.03.2021] 
Chonchol M., Greene T., Zhang Y., Hoofnagle A.N., Cheung A.K., 2016. Low vitamin D and high fibroblast growth factor 23 serum levels associate with infectious and cardiac deaths in the HEMO study. J. Am. Soc. Nephrol. 27(1), 227-237. https://doi.org/10.1681/ASN.2014101009

Colonese F., Laganà A.S., Colonese E., Sofo V., Salmeri F.M., Granese R., Triolo O., 2015. The pleiotropic effects of vitamin $\mathrm{D}$ in gynaecological and obstetric diseases: an overview on a hot topic. Biomed. Res. Int. 986281. https://doi.org/10.1155/2015/986281

Cuppari L., Carvalho A.B., Draibe S.A., 2008. Vitamin D status of chronic kidney disease patients living in a sunny country. J. Ren. Nutr. 18(5), 408-414. https://doi.org/10.1053/j.jrn.2008.05.004

de Boer I.H., Ioannou G.N., Kestenbaum B., Brunzell J.D., Weiss N.S., 2007. 25-hydroxyvitamin D levels and albuminuria in the Third National Health and Nutrition Examination Survey (NHANES III). Am. J. Kidney Dis. 50(1), 69-77. https://doi.org/10.1053/j.ajkd.2007.04.015

de Boer I.H., Kestenbaum B., Shoben A.B., Michos E.D., Sarnak M.J., Siscovick D.S., 2009. 25hydroxyvitamin D levels inversely associate with risk for developing coronary artery calcification. J. Am. Soc. Nephrol. 20(8), 1805-1812. https://doi.org/10.1681/ASN.2008111157

de Zeeuw D., Agarwal R., Amdahl M., Audhya P., Coyne D., Garimella T., Parving H.H., Pritchett Y., Remuzzi G., Ritz E., Andress D., 2010. Selective vitamin D receptor activation with paricalcitol for reduction of albuminuria in patients with type 2 diabetes (VITAL study): a randomised controlled trial. Lancet 376(9752), 1543-1551. https://doi.org/10.1016/S01406736(10)61032-X

Fiedler R., Dorligjav O., Seibert E., Ulrich C., Markau S., Girndt M., 2011. Vitamin D deficiency, mortality, and hospitalization in hemodialysis patients with or without protein-energy wasting. Nephron. Clin. Pract. 119(3), 220-226. https://doi.org/10.1159/000328927

Forman J.P., Giovannucci E., Holmes M.D., Bischoff-Ferrari H.A., Tworoger S.S., Willett W.C., Curhan G.C., 2007. Plasma 25-hydroxyvitamin D levels and risk of incident hypertension. Hypertension 49(5), 1063-1069. https://doi.org/10.1161/HYPERTENSIONAHA.107.087288

Franca Gois P.H., Wolley M., Ranganathan D., Seguro A.C., 2018. Vitamin D deficiency in chronic kidney disease: recent evidence and controversies. Int. J. Environ. Res. Public Health 15(8), 1773. https://doi.org/10.3390/ijerph15081773

Gajewski P. (red.), 2014. Interna Szczeklika. Podręcznik chorób wewnętrznych. Medycyna Praktyczna, Kraków

Galunska B.T., Gerova D.I., Paskalev D.N., Zorcheva B.Y., Ikonomov V.C., Vladimirov V., Svinarov D.A., 2015. Prevalence of vitamin D deficiency in different groups of chronic renal failure patients. J. Imab. 21(3), 887-890. https://doi.org/10.5272/jimab.2015213.887

García-Canton C., Bosch E., Ramírez A., Gonzalez Y., Auyanet I., Guerra R., Perez M.A., Fernández E., Toledo A., Lago M., Checa M.D., 2011 Vascular calcification and 25-hydroxyvitamin D levels in non-dialysis patients with chronic kidney disease stages 4 and 5. Nephrol. Dial. Transplant. 26(7), 2250-2256. https://doi.org/10.1093/ndt/gfq650

Goldsmith D.J.A., 2016. Should we correct vitamin D deficiency/insufficiency in chronic kidney disease patients with inactive forms of vitamin $D$ or just treat them with active vitamin $D$ forms? Nephrol. Dialysis Transplantation, 31(5), 698-705. https://doi.org/10.1093/ndt/gfw082

González E.A., Sachdeva A., Oliver D.A., Martin K.J., 2004. Vitamin D insufficiency and deficiency in chronic kidney disease. A single center observational study. Am. J. Nephrol. 24(5), 503-10. https://doi.org/10.1159/000081023

Grant W.B., 2015. 25-hydroxyvitamin D and breast cancer, colorectal cancer, and colorectal adenomas: case-control versus nested case-control studies. Anticancer Res. 35(2), 1153-1160.

Grant W.B., 2016. Roles of solar UVB and vitamin D in reducing cancer risk and increasing survival. Anticancer Res. 36(3), 1357-70.

Henry H.L., Bouillon R., Norman A.W., Gallagher J.C., Lips P., Heaney R.P., Vieth R., Pettifor J.M., Dawson-Hughes B., Lamberg-Allardt C.J., Ebeling P.R., 2010. 14th vitamin D workshop 
consensus on vitamin D nutritional guidelines. J. Steroid Biochem. Mol. Biol. 121(1-2), 4-6. https://doi.org/10.1016/j.jsbmb.2010.05.008

Holick M.F., 2007. Vitamin D deficiency. N. Engl. J. Med. 357(3), 266-281. https://doi.org/10.1056/NEJMra070553

Holick M.F., 2008. Sunlight, UV-radiation, vitamin D and skin cancer: how much sunlight do we need? Adv. Exp. Med. Biol. 624, 1-15. https://doi.org/10.1007/978-0-387-77574-6_1

Inda Filho A.J., Melamed M.L., 2013. Vitamin D and kidney disease: what we know and what we do not know. J. Bras. Nefrol. 35(4), 323-331. https://doi.org/10.5935/0101-2800.20130051

KDIGO, 2017. Kidigo 2017 clinical practice guideline update for the diagnosis, evaluation, prevention, and treatment of chronic kidney disease-mineral and bone disorder (CKD-MBD). Kidney Int. Suppl. 7, 1-59.

Kim M.J., Frankel A.H., Donaldson M., Darch S.J., Pusey C.D., Hill P.D., Mayr M., Tam F.W., 2011. Oral cholecalciferol decreases albuminuria and urinary TGF- $\beta 1$ in patients with type 2 diabetic nephropathy on established renin-angiotensin-aldosterone system inhibition. Kidney Int. 80(8), 851-60. https://doi.org/10.1038/ki.2011.224

Krause R., Roth H.J., Kaase H., Stange R., Holick M.F., 2016. Vitamin D status in chronic kidney disease - UVB irradiation is superior to oral supplementation. Anticancer Res. 36(3), 13971401.

LaClair R.E., Hellman R.N., Karp S.L., Kraus M., Ofner S., Li Q., Graves K.L., Moe S.M., 2005. Prevalence of calcidiol deficiency in CKD: a cross-sectional study across latitudes in the United States. Am. J. Kidney Dis. 45(6), 1026-1033. https://doi.org/10.1053/j.ajkd.2005.02.029

Makibayashi K., Tatematsu M., Hirata M., Fukushima N., Kusano K., Ohashi S., Abe H., Kuze K., Fukatsu A., Kita T., Doi T., 2001. A vitamin D analog ameliorates glomerular injury on rat glomerulonephritis. Am. J. Pathol. 158(5), 1733-1741. https://doi.org/10.1016/S00029440(10)64129-6

Matias P.J., Jorge C., Ferreira C., Borges M., Aires I., Amaral T., Gil C., Cortez J., Ferreira A., 2010. Cholecalciferol supplementation in hemodialysis patients: effects on mineral metabolism, inflammation, and cardiac dimension parameters. Clin. J. Am. Soc. Nephrol. 5(5), 905-911. https://doi.org/10.2215/CJN.06510909

Melamed M.L., Eustace J.A., Plantinga L., Jaar B.G., Fink N.E., Coresh J., Klag M.J., Powe N.R., 2006. Changes in serum calcium, phosphate, and PTH and the risk of death in incident dialysis patients: a longitudinal study. Kidney Int. 70(2), 351-7. https://doi.org/10.1038/sj.ki.5001542

Molina P., Górriz J.L., Molina M.D., Peris A., Beltrán S., Kanter J., Escudero V., Romero R., Pallardó L.M., 2014. The effect of cholecalciferol for lowering albuminuria in chronic kidney disease: a prospective controlled study. Nephrol. Dialysis Transplantation, 29(1), 97-109. https://doi.org/10.1093/ndt/gft360

Nakashima A., Yokoyama K., Yokoo T., Urashima M., 2016. Role of vitamin D in diabetes mellitus and chronic kidney disease. World J. Diabetes 7(5), 89-100. https://doi.org/10.4239/wjd.v7.i5.89

National Kidney Foundation Evaluation and Treatment of Chronic Kidney Disease-Mineral and Bone Disorder (CKD-MBD) [accessed on 19 August 2018]. Available online: https://www.kidney.org/sites/default/files/02-10-390B_LBA_KDOQI_BoneGuide.pdf. [dostęp 24.03.2021]

Pilz S., Iodice S., Zittermann A., Grant W.B., Gandini S., 2011 a. Vitamin D status and mortality risk in CKD: a meta-analysis of prospective studies. Am. J. Kidney Dis. 58(3), 374-82. https://doi.org/10.1053/j.ajkd.2011.03.020

Pilz S., Tomaschitz A., Friedl C., Amrein K., Drechsler C., Ritz E., Boehm B.O., Grammer T.B., März W., 2011 b. Vitamin D status and mortality in chronic kidney disease. Nephrol. Dial. Transplant. 26(11), 3603-3609. https://doi.org/10.1093/ndt/gfr076

Pittas A.G., Dawson-Hughes B., Li T., Van Dam R.M., Willett W.C., Manson J.E., Hu F.B., 2006. Vitamin D and calcium intake in relation to type 2 diabetes in women. Diabetes Care. 29(3), 650-656. https://doi.org/10.2337/diacare.29.03.06.dc05-1961 
Pludowski P., Holick M.F., Pilz S., Wagner C.L., Hollis B.W., Grant W.B., Shoenfeld Y., Lerchbaum E., Llewellyn D.J., Kienreich K., Soni M., 2013. Vitamin D effects on musculoskeletal health, immunity, autoimmunity, cardiovascular disease, cancer, fertility, pregnancy, dementia and mortality - a review of recent evidence. Autoimmun. Rev. 12(10), 976-989. https://doi.org/10.1016/j.autrev.2013.02.004

Płudowski P., Karczmarewicz E., Bayer M., 2013. Practical guidelines for the supplementation of vitamin D and the treatment of deficits in Central Europe - recommended vitamin D intakes in the general population and groups at risk of vitamin D deficiency. Endokrynol. Pol. 64(4), 319327. https://doi.org/10.5603/ep.2013.0012

Płudowski P., Misiorowski W., Konstantynowicz J., 2016. Profilaktyka i leczenie niedoboru witaminy D - wybór właściwych rekomendacji. Postępy N. Med. 10, 738-746.

Ravani P., Malberti F., Tripepi G., Pecchini P., Cutrupi S., Pizzini P., Mallamaci F., Zoccali C., 2009. Vitamin D levels and patient outcome in chronic kidney disease. Kidney Int. 75(1), 8895. https://doi.org/10.1038/ki.2008.501

Restrepo Valencia C.A., Aguirre Arango J.V., 2019. Vitamin D (25(OH)D) in patients with chronic kidney disease stages 2-5. Colomb. Med. 47(3), 160-166.

Rusińska A., Płudowski P., Walczak M., 2018. Vitamin D supplementation guidelines for general population and groups at risk of vitamin D deficiency in Poland. Recommendations of the Polish Society of Pediatric Endocrinology and Diabetes and the expert panel with participation of national specialist consultants and representatives of scientific societies. Front. Endocrinol. (Lausanne) 31(9), 246. https://doi.org/10.3389/fendo.2018.00246.

Rutkowski B., 2013. Przewlekła choroba nerek — dziesięć lat w teorii i praktyce. Forum Nefrol., 63-70.

Sajkowska J.J., Paradowska K,, 2014. Wielokierunkowe działanie witaminy D. Biul. Wydz. Farm. WUM 1, 1-6.

Samaan F., Carvalho A.B., Pillar R., Rocha L.A., Cassiolato J.L., Cuppari L., Canziani M.E.F., 2019. The effect of long-term cholecalciferol supplementation on vascular calcification in chronic kidney disease patients with hypovitaminosis D. J. Ren. Nutr. 29(5), 407-415. https://doi.org/10.1053/j.jrn.2018.12.002

Shoben A.B., Rudser K.D., de Boer I.H., Young B., Kestenbaum B., 2008. Association of oral calcitriol with improved survival in nondialyzed CKD. J. Am. Soc. Nephrol. 19(8), 1613-1619. https://doi.org/10.1681/ASN.2007111164

Souberbielle J.C., Body J.J., Lappe J.M., Plebani M., Shoenfeld Y., Wang T.J., Bischoff-Ferrari H.A., Cavalier E., Ebeling P.R., Fardellone P., Gandini S., Gruson D., Guérin A.P., Heickendorff L., Hollis B.W., Ish-Shalom S., Jean G., von Landenberg P., Largura A., Olsson T., Pierrot-Deseilligny C., Pilz S., Tincani A., Valcour A., Zittermann A., 2010. Vitamin D and musculoskeletal health, cardiovascular disease, autoimmunity and cancer: recommendations for clinical practice. Autoimmun. Rev. 9(11), 709-15. https://doi.org/10.1016/j.autrev.2010.06.009

Staszków M.I., Przedlacki J., 2014 Zalecenia postępowania w zaburzeniach mineralno-kostnych w przewlekłej chorobie nerek. Wiad. Lek. 67(3), 422-425.

Szeja N., 2017. Witamina D jako związek o działaniu plejotropowym - przegląd aktualnych badań. Pleiotropic effects of vitamin D - a review of current studie Pomeranian J. Life Sci. 63(4), $128-134$.

Teng M., Wolf M., Ofsthun M.N., Lazarus J.M., Hernán M.A., Camargo C.A. Jr, Thadhani R., 2005. Activated injectable vitamin D and hemodialysis survival: a historical cohort study. J. Am. Soc. Nephrol. 16(4), 1115-1125. https://doi.org/10.1681/ASN.2004070573

Tripkovic L., Lambert H., Hart K., Smith C.P., Bucca G., Penson S., Chope G., Hyppönen E., Berry J., Vieth R., Lanham-New S., 2012. Comparison of vitamin $\mathrm{D}_{2}$ and vitamin $\mathrm{D}_{3}$ supplementation 
in raising serum 25-hydroxyvitamin D status: a systematic review and meta-analysis. Am. J. Clin. Nutr. 95(6), 1357-1364. https://doi.org/10.3945/ajcn.111.031070

Wang F., Wu S., Ruan Y., Wang L., 2015. Correlation of serum 25-hydroxyvitamin D level with vascular calcification in hemodialysis patients. Int. J. Clin. Exp. Med. 8(9), 15745-15751.

Wiśniewski P., Nessler J., 2016. Witamina D a układ krążenia. Kardiol. Inwazyjna 11(5), 62-68.

Wolf M., Shah A., Gutierrez O., Ankers E., Monroy M., Tamez H., Steele D., Chang Y., Camargo C.A. Jr, Tonelli M., Thadhani R., 2007. Vitamin D levels and early mortality among incident hemodialysis patients. Kidney Int. 72(8), 1004-1013. https://doi.org/10.1038/sj.ki.5002451

Zheng Z., Shi H., Jia J., Li D., Lin S., 2013. Vitamin D supplementation and mortality risk in chronic kidney disease: a meta-analysis of 20 observational studies. BMC Nephrol. 25(14), 199. https://doi.org/10.1186/1471-2369-14-199

Zhu N., Wang J., Gu L., Wang L., Yuan W., 2015. Vitamin D supplements in chronic kidney disease. Renal Failure, 37(6), 917-924. https://doi.org/10.3109/0886022X.2015.1043920 


\title{
Preferencje żywieniowe dzieci i decyzje zakupowe rodziców dotyczące produktów mlecznych
}

\author{
Children's nutritional preferences and parents' purchasing decisions in relation \\ to the dairy products
}

Konsumenci XXI w. wydają się być świadomymi nabywcami produktów spożywczych. Mają większą wiedzę na temat roli żywienia oraz jego wpływu na funkcjonowanie organizmu. Rozumieją, że ich dieta powinna być urozmaicona i bogata w produkty nisko przetworzone. Wiele osób stara się jeść zdrowo, stosuje zbilansowaną dietę, jednak duża grupa popełnia błędy żywieniowe, które szkodzą ich zdrowiu. Wiele uwagi, zarówno w literaturze przedmiotu, jak i w prowadzonych badaniach, poświęca się racjonalnemu żywieniu dzieci. Rodzice na każdym etapie życia swoich pociech wprowadzają do diety nowe produkty, smaki, składniki potrzebne do prawidłowego rozwoju. To rodzice kształtują nawyki żywieniowe swojego dziecka. Należy podkreślić, że wiek wczesnoszkolny to szczególny czas w życiu każdego dziecka. Wiąże się on z rozpoczęciem nauki i podejmowaniem intensywnego wysiłku intelektualnego, nabywaniem nowych umiejętności, doskonaleniem sprawności fizycznej oraz nawiązywaniem nowych kontaktów z rówieśnikami [Bielaszka i in. 2014]. W tym intensywnym okresie rozwoju umysłowego i fizycznego należy zwrócić szczególną uwagę na prawidłowe żywienie. Przestrzeganie zasad zdrowego odżywiania pozwala bowiem dziecku w młodszym wieku szkolnym prawidłowo funkcjonować (rosnąć, uczyć się, bawić) oraz może zapobiec wielu chorobom, m. in. niedowadze, nadwadze, otyłości, cukrzycy, osteoporozie czy nawet ADHD [Woś i Staszewska-Kwak 2008].

Prawidłowe żywienie, inaczej zbilansowana dieta, ma za zadanie dostarczyć organizmowi z posiłkami niezbędnych składników pokarmowych w odpowiedniej ilości i we właściwych porcjach oraz energię niezbędną do prawidłowego rozwoju umysłowego i fizycznego. Potrzeby żywieniowe niemowląt, małych dzieci, dzieci w wieku przedszkolnym, wczesnoszkolnym i szkolnym różnią się od siebie [Socha 2002]. Dieta dziecka powinna być zróżnicowana i powinna zawierać produkty o wysokiej wartości odżywczej, które pokrywają zapotrzebowanie na wszystkie niezbędne składniki pokarmowe [WośStaszewska-Kwak 2008, Bielaszka i in. 2014]. Dzieci w wieku wczesnoszkolnym dynamicznie rosną i rozwijają się. Aby zapewnić prawidłowy rozwój, osiągnąć optymalną

\footnotetext{
${ }^{1}$ Uniwersytet Przyrodniczy w Lublinie, Wydział Nauk o Żywności i Biotechnologii, Studenckie Koło Naukowe Zarządzania Jakością i Bezpieczeństwem Żywności, skn.food.control@gmail.com

${ }^{2}$ Uniwersytet Przyrodniczy w Lublinie, Wydział Nauk o Żywności i Biotechnologii, Katedra Technologii Surowców Pochodzenia Zwierzęcego, justyna.libera@up.lublin.pl
} 
budowę ciała, rozwój emocjonalny i intelektualny, dobre zdrowie i samopoczucie oraz zmniejszyć ryzyko występowania licznych chorób w życiu dorosłym, należy stosować zbilansowaną dietę. Na podstawie wielu badań można stwierdzić, że żywienie w okresie dziecięcym wywiera decydujący wpływ na stan zdrowia w późniejszym okresie życia [Socha 2002]. Zapotrzebowanie na składniki pokarmowe i energię jest regulowane indywidualnie. Zależy w dużym stopniu od wieku, płci, aktywności fizycznej, nawyków żywieniowych czy fazy rozwoju dziecka [Stankiewicz i Pęgiel-Kamrat 2006]. Zbilansowana dieta powinna składać się z różnorodnych produktów, które dzielimy na 9 grup: mleko i przetwory mleczne; mięso, wędliny i ryby; produkty zbożowe; warzywa i owoce; ziemniaki, tłuszcze; orzechy i suche nasiona roślin strączkowych; cukier i słodycze [Woś i Staszewska-Kwak 2008]. Badania wykazują, że spożywanie przez dzieci produktów mlecznych fermentowanych gwarantuje wiele pozytywnych korzyści oraz wpływa profilaktyczne na rozwój zębów i kośćca [Libudzisz 1999, Jeżewska-Zychowicz 2004, Zmarzlicki 2006, Stankiewicz i Lange 2012].

Jednym z głównych elementów wpływających na zdrowie człowieka są zachowania żywieniowe. Ich kształtowanie w wieku szkolnym zależy od wielu czynników. Są to $\mathrm{m}$. in. czynniki środowiskowe, demograficzne, kulturowe, społeczne [Gajewska i Zawieska 2009]. Czynniki środowiskowe można podzielić na otoczenie bliższe, do którego należy rodzina i szkoła, oraz otoczenie dalsze, do którego zaliczamy np.: reklamy. Dzieci poprzez obserwację zachowań rodziny i informacje, jakie otrzymują od osób najbliższych pozyskują wiedzę dotyczącą żywienia [Sosnowska-Bielicz i Wrótniak 2013]. Na kształtowanie nawyków żywieniowych u dzieci oddziałują również grupy rówieśnicze, które często prowadzą do zmiany dobrych nawyków żywieniowych na niekorzystne. W dzisiejszych czasach na formowanie zachowań żywieniowych (nie tylko dzieci) duży wpływ mają reklamy produktów spożywczych czy mody żywieniowe. Reklamy telewizyjne i internetowe skłaniają do kupowania i spożywania produktów niezdrowych, ubogich w wartościowe składniki pokarmowe, a bogatych w szkodliwe. Prowadzi to do nieprawidłowego stylu żywienia i wielu problemów ze zdrowiem. Jeśli rodzice nie utrwalili prawidłowych nawyków, dzieci są podatne na błędy żywieniowe. Nie potrafią samodzielnie dokonać selekcji wartościowych i niezdrowych przekąsek, dlatego okres wczesnoszkolny jest najlepszym momentem na kształtowanie prozdrowotnych nawyków żywieniowych u dzieci [Sosnowska-Bielicz i Wrótniak 2013].

Żywienie w wieku wczesnoszkolnym, czyli okresie intensywnego rozwoju intelektualnego i fizycznego, powinno dostarczyć niezbędnych składników oraz zabezpieczyć przed wieloma chorobami dietozależnymi [Bielaszka i in. 2014]. Niestety tak nie jest, ponieważ rodzice i dzieci popełniają wiele błędów, które mogą być spowodowane brakiem wiedzy o prawidłowym żywieniu lub złymi nawykami żywieniowym. Według przeprowadzonych badań można wskazać wiele czynników, które negatywnie oddziałują na zdrowie [Kozłowska-Wojciechowska i in. 2002]. Do najczęściej popełnianych błędów żywieniowych u dzieci w wieku wczesnoszkolnym należą: brak niektórych posiłków, zbyt mała ich ilość, zbyt krótki czas na ich spożycie, brak regularności i zbyt długie przerwy miedzy posiłkami lub zbyt krótkie (spowodowane podjadaniem), a także monotonia i małe urozmaicenie posiłków, nerwowa atmosfera podczas ich spożywania oraz rozpra- 
szanie uwagi dziecka w czasie jedzenia. Niekorzystne czynniki wpływające na stan zdrowia to również spożywanie zbyt dużej ilości słodyczy, napojów słodkich, napojów energetycznych czy produktów typu fast food. Obecnie w diecie dzieci dominują: mięso, tłuszcze i węglowodany, które spożywane w nadmiarze szkodzą. Jednym z największych błędów, jakie popełniają rodzice i dzieci jest brak śniadania, które jest najważniejszym posiłkiem w ciągu dnia, ponieważ dostarcza energię do nauki, zabawy i prawidłowego funkcjonowania [Jarosz i Rychlik 2010, Sosnowska-Bielicz i Wrótniak 2013]. Wymienione wyżej czynniki prowadzą do zaburzenia odżywania, skutkują nieprawidłowym rozwojem i często są przyczyną wielu chorób.

Długotrwałe niedobory składników pokarmowych mogą prowadzić do spadku energetyczno-białkowego, co może skutkować zahamowaniem rozwoju intelektualnego i fizycznego, zaburzeniami układu odpornościowego, wpływać negatywnie na funkcje poznawcze, zwiększać drażliwość i prowadzić do problemów z koncentracją [Gajewska i Zawieska 2009]. Niedobór witaminy D i wapnia może doprowadzić do nieprawidłowej mineralizacji kości, czego skutkiem będzie zmniejszenie masy kostnej, która negatywnie wpłynie na rozwój dziecka. Niewłaściwa ilość żelaza, folianów, witaminy $\mathrm{B}_{6}$ i $\mathrm{B}_{12}$, miedzi, cynku i innych mikroelementów może prowadzić do wystąpienia niedokrwistości. Niedożywienie oddziałuje negatywnie również na płaszczyźnie społecznej (obawa przed brakiem akceptacji przez rówieśników) oraz psychologicznej (obniżona samoocena).

Nadmierne spożycie różnego typu produktów, głównie przetworzonych i dosładzanych prowadzi do nadwagi, natomiast długotrwałe prowadzenie takiego trybu życia do otyłości [Jarosz i Rychlik 2010]. Przyczyną nadmiernej masy ciała może być jedzenie dużej ilości tłuszczów zwierzęcych, słodyczy, produktów typu fast food, zbyt duża kaloryczność posiłków spożywanych w ciągu dnia oraz zbyt mała aktywność fizyczna. Zwiększona masa ciała wpływa na zdrowie w kolejnych etapach życia człowieka. Zwiększa ona ryzyko rozwoju przewlekłych chorób. Otyłość może prowadzić do oporności insulinowej, chorób układu sercowo-naczyniowego, cukrzycy typu 2, dyslipidemi, stłuszczenia wątroby, dysfunkcji śródbłonka oraz skoliozy, a nawet przyczynić się do rozwoju nowotworu [Sikorska-Wiśniewska 2007, Jarosz i Rychlik 2010, Sosnowska-Bielicz i Wrótniak 2013]. Nadmierna masa ciała wpływa również na jakość życia dzieci w relacjach z innymi i na płaszczyźnie psychicznej. Problem nadwagi i otyłości występuje coraz częściej u małych dzieci. Jeżeli rodzice nie zmienią sposobu odżywiania dzieci, to według WHO do 2025 r. na świecie będzie $70 \mathrm{mln}$ dzieci do 5 r.ż., u których zostanie stwierdzona nadmierna masa ciała. W Polsce zaobserwowano, że 10\% dzieci w wieku 1-3 lata, 30\% w wieku wczesnoszkolnym i $22 \%$ do 15 r.ż. już ma problemy z nadwagą i otyłością.

Mleko w żywieniu dzieci pełni kluczową rolę, ponieważ ma wiele wartości odżywczych. Cechuje się bardzo urozmaiconym składem i dużą gęstością odżywczą. Według badań mleko i jego przetwory stanowią niezbędny i wartościowy składnik pożywienia większości ludzi na świecie. Dzięki roli, jaką odgrywają produkty mleczne w trakcie intensywnego wzrostu i rozwoju dzieci i młodzieży, powinny one stanowić jeden z głównych elementów zbilansowanej diety [Jeżewska-Zychowicz 2004]. Na podstawie badań stwierdza się, jak wiele korzyści dla zdrowia przynoszą składniki odżywcze występujące w mleku i jego przetworach [Zmarzlicki 2006]. Zapobiegają one cukrzycy typu II, chorobom nowotworowym, miażdżycy, osteoporozie, kamicy nerkowej i wielu innym. 
W ostatnich latach przeprowadzono badania, które wykazały, że obecność witaminy D, wapnia i tłuszczu mlecznego pochodzącego z mleka i jego przetworów zmniejszyła ryzyko rozwoju otyłości.

Białka serwatkowe obecne w mleku mają dużą wartość odżywczą dzięki zawartej w nich lizynie i aminokwasach siarkowych (cystyna i cysteina). W ich skład wchodzą laktoalbumina- $\alpha$, laktoglobulina- $\beta$, albumina serum krwi (stanowią one $75 \%$ białek serwatkowych), immunoglobuliny, które mają właściwości odpornościowe, transferyna i laktoferyna, które przenoszą żelazo. Laktoferyna wykazuje działanie przeciwzapalne i bakteriostatyczne. Zawartość białka w mleku to 3\%, w serach twarogowych 10-21\%, a w serach podpuszczkowych $18-30 \%$ [Król i in. 2011].

Do najważniejszych składników pokarmowych wchodzących w skład mleka i jego przetworów zalicza się: łatwo przyswajalny wapń, fosfor, potas, magnez, cynk, białka, thuszcze, witaminy rozpuszczalne $\mathrm{w}$ thuszczu $\mathrm{A}, \mathrm{D}, \mathrm{E}$ i rozpuszczalne $\mathrm{w}$ wodzie $\mathrm{z}$ grupy $\mathrm{B}$ (głównie $\mathrm{B}_{2}$ ). Wapń obecny w mleku i produktach mlecznych jest najważniejszym składnikiem mineralnym. Stanowi on podstawowy i niezbędny materiał budulcowy kości i zębów, wspomaga prawidłową pracę serca i układu naczyniowego, bierze udział w przewodzeniu bodźców nerwowych, jest jednym z czynników odpowiedzialnych za krzepnięcie krwi, kofaktor enzymów, odpowiada za kurczliwość mięśni oraz zmniejsza przepuszczalność błon komórkowych. Wapń zmniejsza ryzyko otyłości, nadciśnienia tętniczego, chorób serca czy raka piersi. Niedobór wapnia może doprowadzić do niedostatecznej mineralizacji kości, co skutkuje wystąpieniem krzywicy, osteoporozy czy osteomalacji. Mogą wystąpić zaburzenia procesu krzepnięcia krwi oraz drżenia mięśni. Aby zapobiegać takim schorzeniom, należy spożywać zalecaną dzienną dawkę wapnia, dla dzieci w wieku 7-9 lat wynosi ona $1000 \mathrm{mg}$. Produktami mlecznymi zawierającymi go najwięcej są sery podpuszczkowe i twarogowe.

\section{Cel pracy}

Celem badania była ocena preferencji zakupowych rodziców odnośnie produktów mlecznych, które wybierają dla swoich dzieci. Kwestionariusz przeprowadzony został stacjonarnie, wśród rodziców klas 1-3 w szkole podstawowej w Radomiu. Przeprowadzona ankieta miała na celu sprawdzenie częstotliwości spożywania i najczęściej wybieranych produktów mlecznych oraz preferowanych form ich podania.

\section{Metody badawcze}

\section{Narzędzie badawcze - ankieta}

Ankieta dotyczy spożycia produktów mlecznych przez dzieci w wieku 6-10 lat. Pierwsze trzy pytania są pytaniami otwartymi, natomiast pytania od czwartego do dwudziestego siódmego to pytania zamknięte jednokrotnego lub wielokrotnego wyboru.

W pierwszych trzech pytaniach rodzice podawali wiek, wzrost i masę ciała dziecka. Następne dwa pytania dotyczyły częstości chorowania i przyjmowania antybiotyków 
przez dzieci. W pytaniu szóstym i siódmym sprawdzano, czy dzieci dostają produkty mleczne na drugie śniadanie oraz czy kupują je w sklepiku szkolnym. Kolejne trzy pytania dotyczyły „Programu dla szkół”: jakie produkty dostaje dziecko, jak często je otrzymuje i czy je spożywa. Pytanie jedenaste miało na celu zbadanie częstości spożywania produktów mlecznych przez dzieci. Dwunaste poświęcone było alergii lub nietolerancji pokarmowych na produkty mleczne. Pytania trzynaste i czternaste sprawdzały, jakie produkty preferują dzieci oraz jakie podają im rodzice. W piętnastym pytaniu należało zaznaczyć firmy, których produkty mleczne najczęściej są kupowane. Pytanie szesnaste i siedemnaste miały na celu ocenić, na co zwracają uwagę rodzice podczas kupowania produktów mlecznych i, czy wybierając nowy produkt, czytają skład. Pytania od osiemnastego do dwudziestego trzeciego dotyczyły mleka, natomiast pytania od dwudziestego czwartego do dwudziestego siódmego - jogurtu.

\section{Uczestnicy badania}

Badanie polegało na przeprowadzeniu ankiety dotyczącej spożycia produktów mlecznych przez dzieci w wieku wczesnoszkolnym. Kwestionariusz składał się z 27 pytań. W badaniu udział wzięło 72 rodziców, $25 \mathrm{z}$ nich to rodzice dzieci w wieku 9 lat, 24 osoby miały dzieci w wieku 8 lat, natomiast pozostali, czyli 23 rodziców miało dziecko w wieku 7 lat. Ankieta została przeprowadzona wśród rodziców dzieci z pierwszej, drugiej i trzeciej klasy. Badanie odbyło się 19 listopada 2019 r. w szkole podstawowej nr 33 w Radomiu.

Przeprowadzoną ankietę poddano analizie, a wyniki przedstawiono za pomocą wykresów z wartościami procentowymi, co pozwoliło na uzyskanie ogólnych informacji odnośnie podawania przez rodziców i spożywania przez dzieci produktów mlecznych.

\section{Wyniki badań}

Zaobserwowano, że spożycie produktów mlecznych pozytywnie wpływa na odporność dzieci. Tylko 17\% respondentów zadeklarowało, że ich dzieci często chorują, a 11\% z nich, że często przyjmują antybiotyki. Produkty mleczne bardzo często spożywane są w domu. Aż $28 \%$ ankietowanych nigdy nie daje ich swoim dzieciom na drugie śniadanie do szkoły (ryc. 1). Może to być spowodowane brakiem możliwości przechowywania tych produktów w chłodnym miejscu lub faktem, że są niewygodne do spożycia na korytarzu szkolnym.

W szkołach prowadzone są programy edukacyjne, które kształtują prawidłowe nawyki żywieniowe wśród dzieci. Uczniowie poznają wartości odżywcze różnych grup produktów oraz zasady racjonalnego żywienia. W ramach realizacji tych programów dzieci otrzymują produkty mleczne, np. mleko, jogurty naturalne czy serki waniliowe. Większość rodziców zadeklarowała, że ich dzieci otrzymują wybrany produkt raz w tygodniu, ale tylko $46 \%$ z nich spożywa go zawsze, a $47 \%$ czasami. Jedynie $7 \%$ dzieci nie zjada nigdy produktu otrzymanego w szkole.

Na pytanie dotyczące częstotliwości spożywanych produktów mlecznych $42 \%$ respondentów zadeklarowało, że podaje je swoim dzieciom codziennie (ryc. 2). 


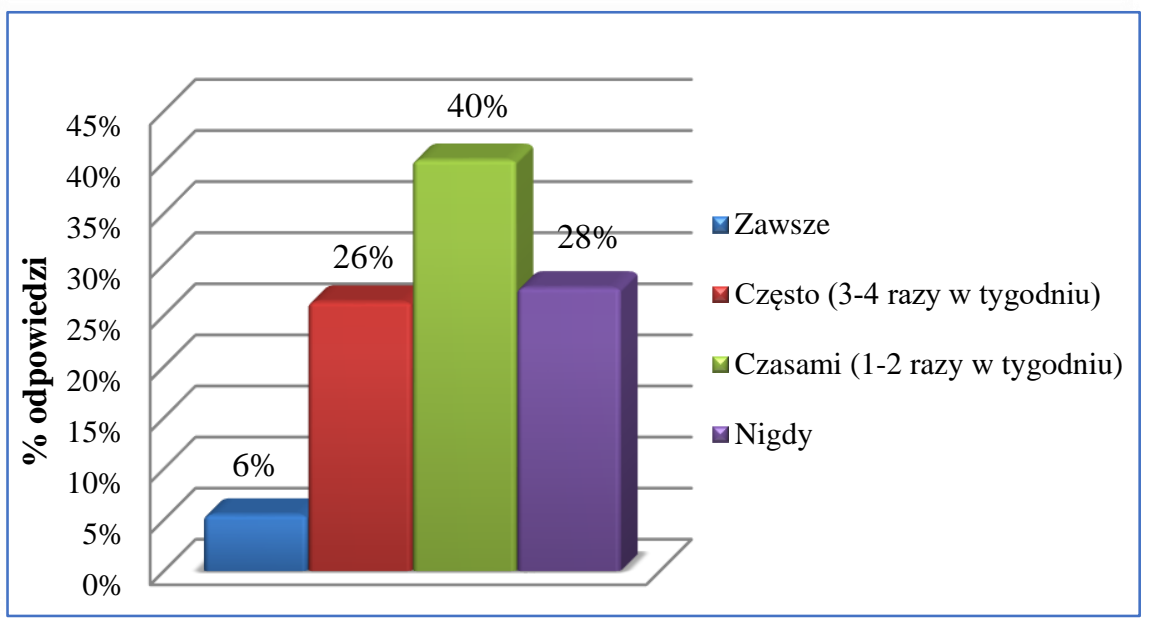

Ryc. 1. Jak często Pana/Pani dziecko dostaje produkty mleczne na drugie śniadanie do szkoły?

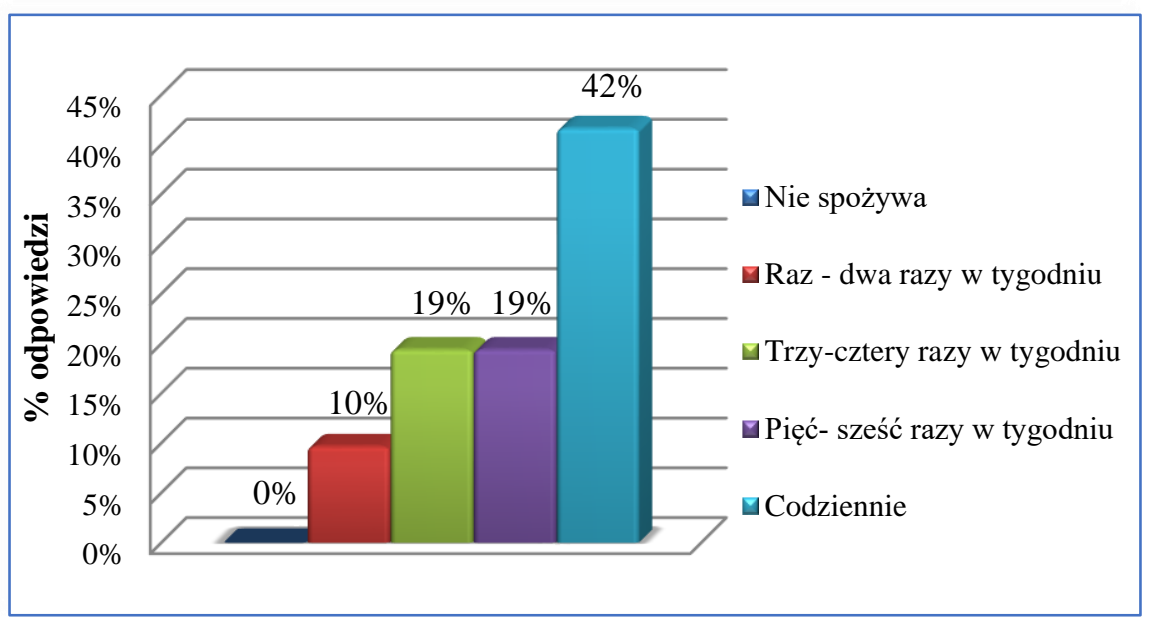

Ryc. 2. Jak często Pana/Pani dziecko spożywa produkty mleczne?

Niestety, aż 50\% rodziców nie dostarcza swojemu dziecku odpowiedniej porcji nabiału, a więc dwóch porcji dziennie. Na pytania dotyczące preferowanych przez dzieci, a podawanych przez rodziców produktów mlecznych, odpowiedzi różniły się nieznacznie (ryc. 3). 
Dzieci preferują serki homogenizowane i desery mleczne, natomiast rodzice rzadziej podają im te produkty, a zastępują je twarogiem i jogurtami. Wzbogacają dietę, podając dzieciom jogurty naturalne, a starają się ograniczać spożycie żółtego sera (ryc. 4).

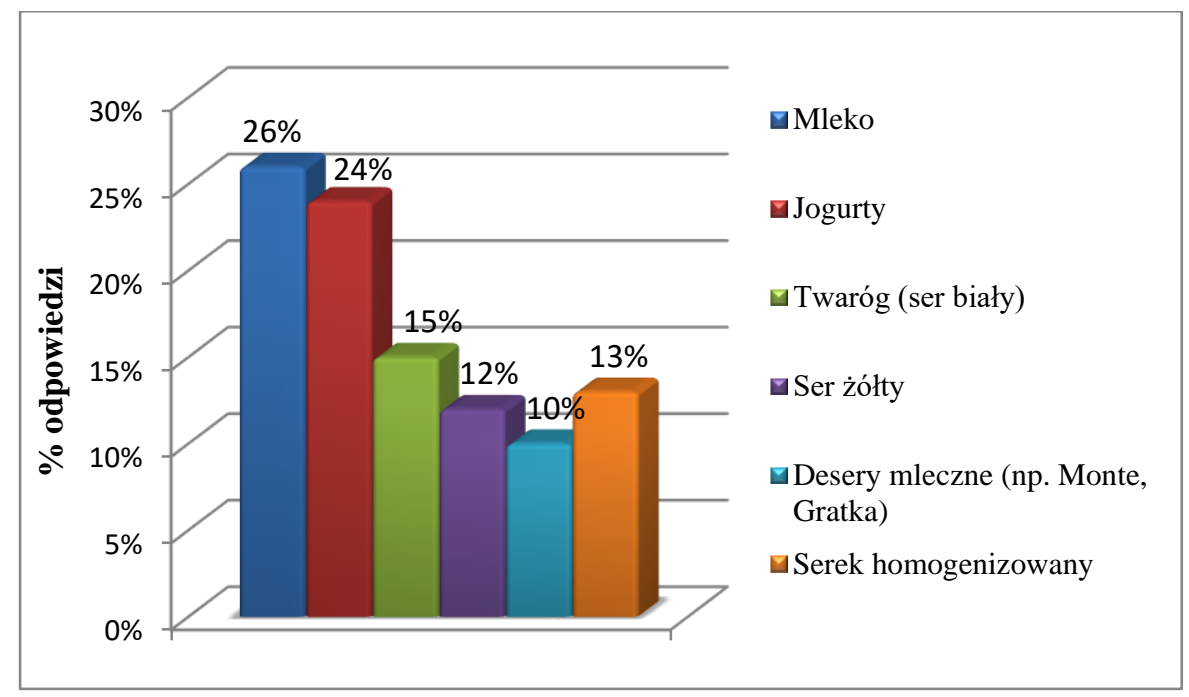

Ryc. 3. Jakie produkty lubi Pana/Pani dziecko?

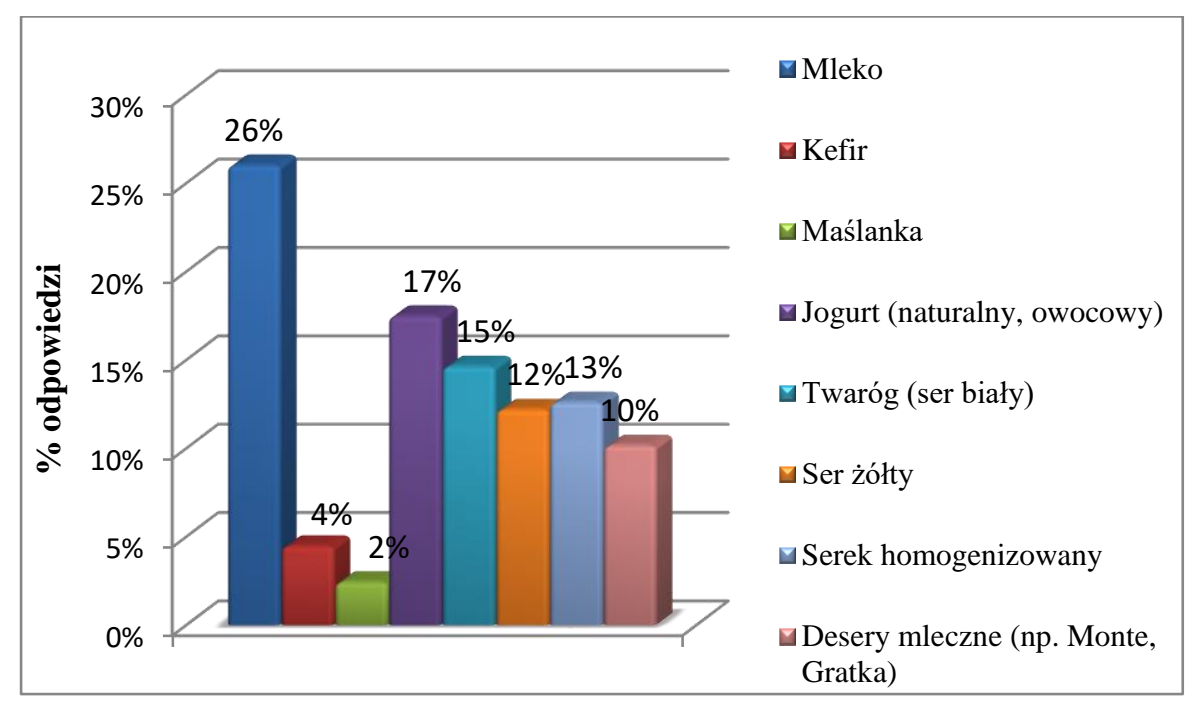

Ryc. 4. Jakie produkty lubi Pana/Pani dziecko? 
W ankiecie znajdowały się dwa pytania dotyczące wyboru marki, której produkty najchętniej kupują rodzice. Pierwsze wiązało się z zakupem wszystkich produktów mlecznych, drugie dotyczyło marki jogurtów. Wyniki odpowiedzi na te dwa pytania były bardzo zbliżone. Większość ankietowanych wybiera firmy znane na rynku, już sprawdzone np. Mlekpol, Danone czy Bakoma. Mniejszą popularnością cieszą się marki tworzone dla danego sklepu czy produkowane w innym regionie Polski, np. Krasnystaw, Bieluch, Łowicz.

Podczas wyboru produktów mlecznych 34\% respondentów kieruje się składem produktu, natomiast zaledwie o $1 \%$ mniej (33\%) bierze pod uwagę tylko cenę produktu (ryc. 5). Większość ankietowanych zadeklarowała, że na ich wybór wpływają oba te czynniki. Innym kryterium, który decyduje o wyborze danego produktu jest marka (17\%). Niewielka ilość badanych zwraca uwagę na dostępność (9\%), opakowanie (3\%) i reklamę (3\%). Podczas kupowania nowego produktu mlecznego ważne jest zapoznanie się z jego składem. Niestety tylko $42 \%$ ankietowanych robi to zawsze. $47 \%$ respondentów zadeklarowało, że zapoznaje się z nim czasami. Może to być spowodowane brakiem czasu podczas robienia zakupów. Niestety, aż 11\% rodziców nigdy nie zapoznaje się ze składem produktu. Może wynikać to z braku wiedzy (np. nieznajomość substancji szkodliwych dla zdrowia dziecka) czy braku czasu.

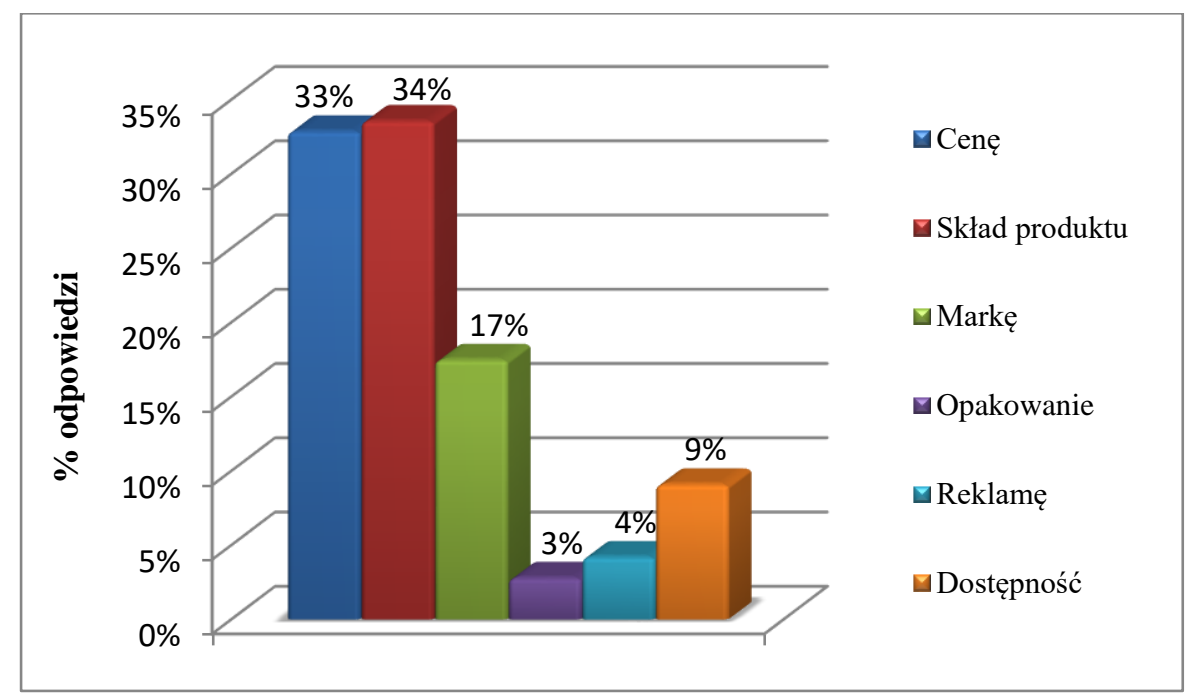

Ryc. 5. Na co zwraca Pan/Pani uwagę kupując produkty mleczne dla swojego dziecka?

Najwięcej rodziców (60\%) zadeklarowało, że ich dzieci spożywają mleko najchętniej z płatkami (np. owsianymi, jaglanymi) lub z chrupkami, natomiast tylko 3\% wybiera mleko bez dodatków (ryc. 6). 


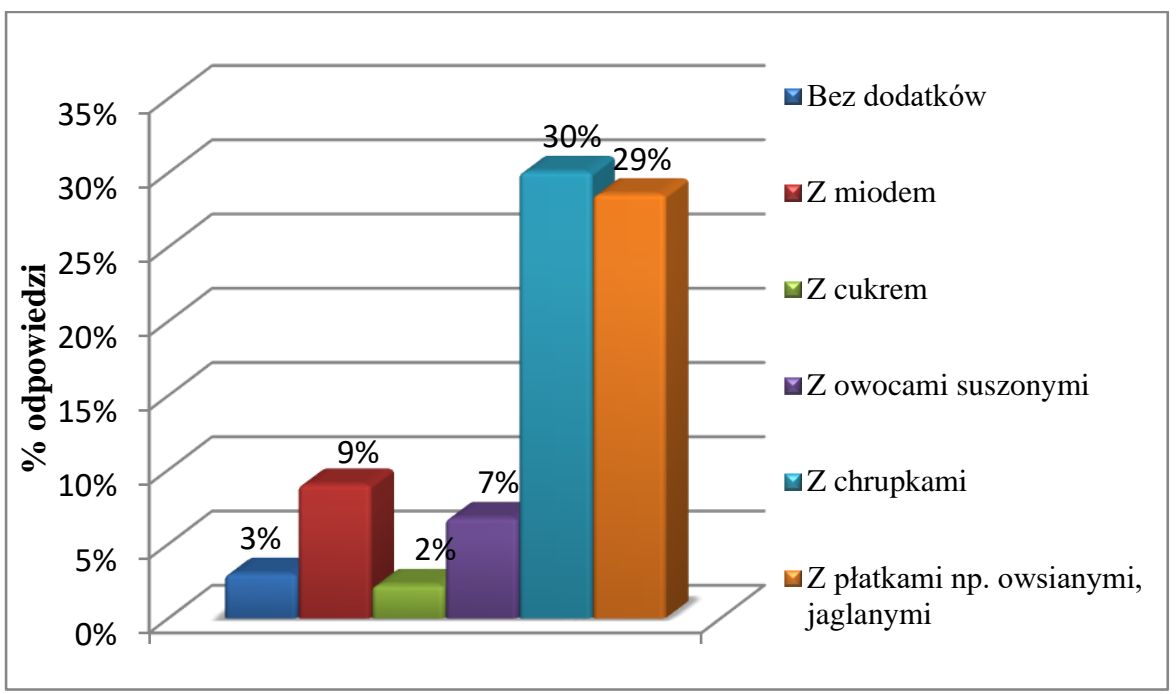

Ryc. 6. Z jakim dodatkiem podaje Pan/Pani mleko swojemu dziecku?

\section{Podsumowanie}

Po przeprowadzeniu badaniach stwierdzono, że tylko $42 \%$ dzieci otrzymuje codzienną porcję nabiału, a ponad połowa badanej grupy spożywa go za mało. Duża grupa rodziców zwraca uwagę, aby nabiał podawany dzieciom był zróżnicowany oraz nie zawierał dodatkowych ilości cukru czy substancji zbędnych w produktach mlecznych. Stwierdzono, że rodzice najczęściej wybierają dla dzieci zwykłe mleko pasteryzowane z dodatkiem chrupek lub płatków. Według deklaracji rodziców większość dzieci preferuje produkty słodkie: serki homogenizowane i desery mleczne, jak również jogurty smakowe oraz ser żółty. Po przeanalizowaniu wyników stwierdzono, że znacznym zainteresowaniem rodziców i dzieci cieszył się twaróg, natomiast rodzice rzadziej niż chciały tego ich dzieci, decydowali się na zakup dosładzanych deserów mlecznych. Rodzice wiedzą, jak ważna jest zbilansowana i bogata w składniki odżywcze dieta dziecka, które rozpoczęło naukę w szkole, niemniej zasadnym, wydaje się, prowadzenie dla nich edukacji, związanej z prawidłowym odżywianiem ich dzieci.

\section{Literatura}

Bielaszka A., Grochowska-Niedworok E., Kiciak A., Szczepańska E., Kardas M., Całyniuk B., Zima-Dańczyk A., 2014. Preferencje żywieniowe dzieci w wieku 7-10 lat. Ann. Acad. Med. Siles. 68(4), 187-191.

Gajewska M., Zawieska D., 2009. Zachowania żywieniowe uczniów szkoły podstawowej w opinii dzieci i ich rodziców. Roczn. PZH 60, 347-351.

Jarosz M., Rychlik E., 2010. Epidemia otyłości - jaka przyszłość nas czeka? Gastroent. Pol. 17(1), $47-52$. 
Jeżewska-Zychowicz M., 2004. The influence of the preferences of dairy products on the consumption among adolescents 13-15. Acta Sci. Pol. Technol. Aliment. 3(2), 171-182.

Kozłowska-Wojciechowska M., Uramowska-Żyto B., Jarosz A., Makarewicz-Wujec M., 2002. Wpływ edukacji żywieniowej dzieci w wieku szkolnym na wiedzę i zachowania żywieniowe ich rodziców. Roczn. PZH 53, 253-258.

Król J., Brodziak A., Litwińczuk A., 2011. Podstawowy sklad chemiczny i zawartość wybranych białek serwatkowych w mleku krów różnych ras i w serwatce podpuszczkowej. Żywn. Nauk. Techno. Jakość 4 (77), 74-83.

Libudzisz Z., 1999. Mikroflora jelitowa a nowe generacje mlecznych napojów fermentowanych. Żyw. Czł. Metabol. Suplement 26, 5-13.

Sikorska-Wiśniewska G., 2007. Nadwaga i otyłość u dzieci i młodzieży. Żywn. Nauk. Technol. Jakość 6 (55), 71-80.

Socha J., 2002. Żywienie a rozwój dziecka w pierwszym roku życia. Nowa Pediatr., 2, 96-102.

Sosnowska-Bielicz E., Wrótniak J., 2013. Nawyki żywieniowe a otyłość dzieci w wieku przedszkolnym i szkolnym. Lub. Rocznik Pedagog. 32, 147-165.

Stankiewicz J., Lange M., 2012. Mleczne napoje fermentowane w żywieniu dzieci w wieku przedszkolnym. Bromat. Chem. Toksykol. 45(2), 191-195.

Stankiewicz M, Pęgiel-Kamrat J., 2006. Styl żywienia dzieci przedszkolnych w opinii ich rodziców. Probl. Hig. Epidemiol. 87(4), 119.

Woś H., Staszewska-Kwak A., 2008. Żywienie dzieci, Wydawnictwo Lekarskie PZWL, Warszawa.

Zmarzlicki S., 2006. Zdrowotne aspekty mleka i przetworów mlecznych. Zdr. Publ. 116(1), $142-146$. 
Aleksandra Such ${ }^{\mathbb{D} 1}$, Anna Pelc, Aneta Koronowicz $\mathbb{D}^{1}$

\section{Ocena stanu wiedzy rodziców na temat wpływu nieprawidłowych zachowań żywieniowych na rozwój otyłości prostej u dzieci - badania ankietowe}

The evaluation of parents' state knowledge about the impact of incorrect dietary behaviors on development of simple obesity in children - surveys

Współcześnie mamy do czynienia z epidemią otyłości. Dotyka ona coraz częściej dzieci i młodzież. Otyłość jest jedną z najważniejszych przewlekłych chorób niezakaźnych i stanowi szóstą pod względem częstości występowania przyczynę zgonów na świecie [Przybylska i in. 2012]. Choroba ta wynika z zaburzeń homeostazy energetycznej i skutkuje zwiększeniem ilości tkanki tłuszczowej w organizmie oraz gromadzeniem się lipidów w narządach [Plich i Bałajewicz 2009].

Przyjmuje się, że umowną granicą, od której mówi się o otyłości jest wartość 120\% należytej masy ciała. Otyłość występuje, gdy ilość tkanki tłuszczowej przewyższa u kobiet $30 \%$ masy ciała, a u mężczyzn $25 \%$, niezależnie od masy ciała, natomiast dzieci uznaje się za otyłe, gdy masa ich ciała przekracza 20\% należnej masy ciała [Ciborowska 2014].

Otyłość, ze względu na przyczynę powstawania klasyfikuje się jako otyłość prostą (jednoobjawowa, samoistna) oraz otyłość wtórną (patologiczna). Najczęściej występującym typem, zarówno u dzieci jak i dorosłych, jest otyłość prosta. Jej przyczyną jest dodatni bilans energetyczny, związany z nadmierną podażą energii dostarczonej wraz z pożywieniem w stosunku do energii wydatkowanej przez organizm. Otyłość prosta jest często uwarunkowana genetycznie, a także przez czynniki środowiskowe, takie jak spożywanie dużych ilości węglowodanów prostych i tłuszczów zwierzęcych oraz niewielką aktywność fizyczną [Maślanek i in. 2013].

Otyłość wtórna może być spowodowana przez choroby, takie jak: zespół Downa, zespół Turnera, niedoczynność tarczycy, zespół Cushinga czy przyjmowaniem leków przeciwdepresyjnych przez długi czas.

Ze względu na rozmieszczenie tkanki podskórnej można wyróżnić dwa typy otyłości. Pierwszy typ to typ gynoidalny, charakteryzujący się rozmieszczeniem tkanki tłuszczowej w okolicach bioder, pośladków i ud. Drugi typ to typ androidalny, który występuje głównie u mężczyzn i charakteryzuje się odkładaniem tłuszczu w okolicach brzucha [Sikorska-Wiśniewska 2007, Przybylska i in. 2012].

\footnotetext{
${ }^{1}$ Uniwersytet Rolniczy im. H. Kołłątaja w Krakowie, Wydział Technologii Żywności, Katedra Żywienia Człowieka i Dietetyki, aleksandra.such1@gmail.com
} 


\section{Otyłość u dzieci i młodzieży}

W ostatnich latach w Polsce i na świecie obserwuje się znaczny wzrost liczby dzieci i młodzieży z otyłością i nadwagą. Podaje się, że co trzeci chłopiec i co piąta dziewczynka w wieku od 6 do 9 lat zmaga się z otyłością, a nadmierna masa ciała dotyka 10\% dzieci i młodzieży na świecie. W 2016 r. około 10\% dzieci w Polsce w wieku 1-3 lat i co 5 dziecko w wieku 10-16 lat miało otyłość lub nadwagę [Kołłajtis-Dołowy i in. 2019]. Przewiduje się, że do 2025 r. liczba dzieci (w wieku 5-17 lat) z nadwagą wzrośnie aż do 177 milionów, a z otyłością do 91 milionów. Pociągnie to za sobą wzrost liczby powikłań będących skutkami otyłości [GIS 2018].

\section{Przyczyny i następstwa otyłości prostej u dzieci}

Jedną z głównych przyczyn otyłości u dzieci i młodzieży są nawyki żywieniowe. Dlatego tak ważne jest, aby rodzice już od najmłodszych lat wpajali dzieciom prawidłowe zasady żywienia i sami byli dla nich wzorem. Zmuszanie dziecka do jedzenia, niewłaściwa liczba i energetyczność posiłków, czy podawanie posiłków w pośpiechu są najczęstszymi błędami, które mogą skutkować nadmierną masą ciała [Maślanek i in. 2013]. Istotnymi czynnikami skutkującymi nadwagą i otyłością są również siedzący tryb życia, mała aktywność fizyczna oraz skrócony czas snu [Aggarwal i Jain 2017].

Otyłość może być również uwarunkowana genetycznie. Najlepiej poznanym genem, który jest związany z otyłością, jest gen kodujący leptynę. Białko to odpowiada za regulacje wydatków energetycznych organizmu, takich jak regulacja pobierania pokarmu oraz wpływa na metabolizm lipidów i węglowodanów [Gogga i in. 2011].

Do konsekwencji otyłości prostej u dzieci można zaliczyć występowanie nadciśnienia tętniczego i zaburzenia profilu lipidowego krwi. Występujące zaburzenia metaboliczne mogą prowadzić do stłuszczenia wątroby [Sikorska-Wiśniewska 2007, Maślanek i in. 2013].

Kolejną z konsekwencji nadmiernej masy ciała mogą być zaburzenia hormonalne, które prowadzą do szybszego dojrzewania dziewczynek. Wczesna miesiączka jest ustalonym czynnikiem ryzyka występowania raka piersi oraz została powiązana z innymi nowotworami układu rozrodczego kobiet. Natomiast chłopcy z wyższą masą ciała dojrzewają później niż ich rówieśnicy o prawidłowej masie [Lobstein i in. 2004].

Wysoce istotnym problemem u otyłych dzieci jest insulinooporność, którą stwierdza się u 46-52\% otyłych dzieci i młodzieży [Gawlik i in. 2009]. Insulinooporność, która jest skutkiem nadmiernej masy ciała, prowadzi w pierwszej kolejności do nietolerancji glukozy, a następnie do cukrzycy typu 2 [Daniels 2009].

Dzieci z wysokim wskaźnikiem BMI są również bardziej narażone na dolegliwości ze strony układu kostnego, takie jak zapalenie kości i stawów [Sikorska-Wiśniewska 2007, Karney i in. 2015]. Kolejnymi z powikłań otyłości są bezdech senny oraz zwiększone ryzyko astmy oskrzelowej [Güngör 2014, Daniels 2009]. U dzieci otyłych obserwuje się również zaburzenia na tle emocjonalnym [Raj i Krishna-Kumar 2010].

W badaniach Międzynarodowej Agencji Badań nad Rakiem (IARC) wykazano, że około pół miliona nowych przypadków raka rocznie może być związanych z wysokim wskaźnikiem masy ciała. Podaje się, że w 2012 r. nadwaga i otyłość były czynnikami ryzyka, odpowiedzialnymi za 3,6\% wszystkich nowych przypadków nowotworów [IARC 2015]. Najpopularniejszymi nowotworami wśród osób otyłych są rak endometrium (u kobiet), rak przełyku, jelita grubego, piersi, wątroby, pęcherzyka żółciowego oraz nerek [Wolin i in. 2010]. 


\section{Zasady prawidłowego żywienia}

Instytut Żywności i Żywienia w 2019 r. przedstawił zaktualizowaną piramidę zdrowego żywienia, która łączy ze sobą prawidłowe żywienie i odpowiedni styl życia. Na jej podstawie opracowano 10 zasad, którymi powinni kierować się rodzice w żywieniu swoich dzieci. Do zasad należą m.in.: regularne spożywanie 5 posiłków dziennie; jak najczęstsze spożywanie warzyw i owoców; spożywanie produktów zbożowych; chudego mięsa, nasion roślin strączkowych, jaj; zastąpienie tłuszczów zwierzęcych tłuszczami roślinnymi; wyeliminowanie z diety słodyczy; unikanie produktów typu fast food; aktywność fizyczna minimum godzinę dziennie; wysypianie się; regularne sprawdzanie wysokości i masy ciała [IŻŻ 2019]. W prawidłowo zbilansowanej diecie, energia powinna pochodzić w $45-60 \% \mathrm{z}$ węglowodanów, 20-35\% z tłuszczów oraz 10-20\% z białka [Jarosz 2020].

Nasze zachowania żywieniowe zostają ukształtowane już w dzieciństwie, a ich nieprawidłowość trudno zmienić w życiu dorosłym. Zachowania żywieniowe obejmują ilość i rodzaj spożywanej żywności regularność posiłków, podjadanie, planowanie zakupów i przechowywanie żywności. W wyrabianiu tych nawyków biorą udział rodzice, grupa rówieśnicza, ale i reklamy [Harton 2013].

Celem niniejszych badań była ocena stanu wiedzy rodziców na temat wpływu nieprawidłowych zachowań żywieniowych na rozwój otyłości prostej u dzieci.

\section{Material i metody}

Narzędziem badawczym pracy była anonimowa ankieta internetowa, skonstruowana przy użyciu „Formularzy Google”.

Wyniki uzyskano na podstawie internetowej ankiety składającej się z 26 pytań. W badaniach wzięło udział 104 rodziców z całej Polski. Zebrane wyniki pozwoliły określić występowanie nadwagi/otyłości w rodzinie, znajomość przyczyn oraz skutków otyłości prostej u dzieci, znajomość zasad wynikających z piramidy zdrowego żywienia, częstotliwość spożycia określonych grup produktów spożywczych oraz preferowanych aktywności fizycznych.

Uzyskane wyniki zostały opracowane przy użyciu programów Statistica 13.1 oraz Microsoft Excel 2007. Do zobrazowania danych użyto wykresów kołowych oraz słupkowych. Weryfikacji różnic między zmiennymi dokonano przy użyciu testu niezależności Chi-kwadrat na poziomie istotności $\mathrm{p}<0,05$.

\section{Wyniki}

Na pytanie o występowanie nadwagi lub otyłości w rodzinie, jednakowa ilość ankietowanych odpowiedziała twierdząco, jak i przecząco (po 49,04\%) (ryc. 1.A). Następnie podano stopień pokrewieństwa osoby z nadwagą/otyłością z dzieckiem i wyróżniono 4 grupy pokrewieństwa: rodzice, rodzeństwo, dziadkowie, wujostwo. Najliczniejszą grupę stanowili dziadkowie - 26 osób, następnie rodzice - 14, rodzeństwo - 7, wujostwo -4 (ryc. 1.B). 
Z analizy znajomości przyczyn (ryc. 2.A) oraz skutków (ryc. 2.B) otyłości prostej u dzieci wynika, że więcej respondentów potrafiło wymienić skutki otyłości $(69,23 \%)$ niż wskazać na jej przyczyny (51,92\%).

A

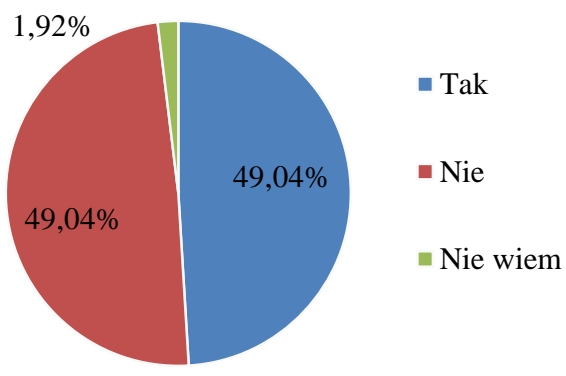

B

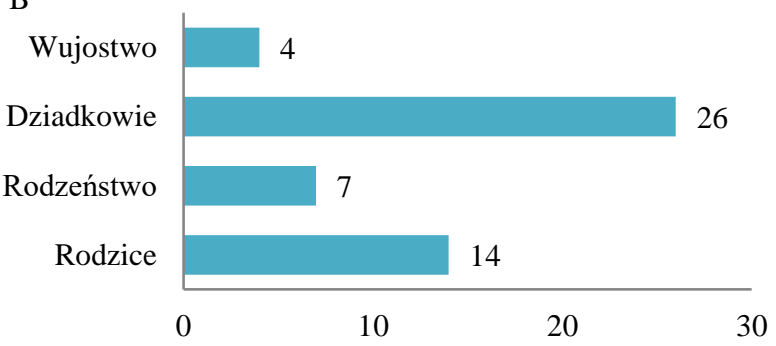

Ryc. 1. Odpowiedź na pytanie „Czy w Pana/Pani rodzinie występuje bądź występowała nadwaga lub otyłość?" (\% osób) (A). Występowanie nadwagi/otyłości w rodzinie ankietowanych z uwzględnieniem stopnia pokrewieństwa z dzieckiem (ilość osób) (B)

A

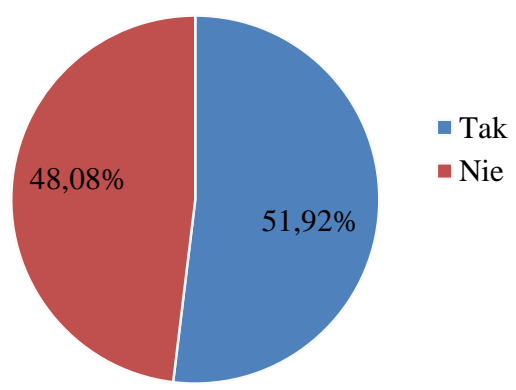

B

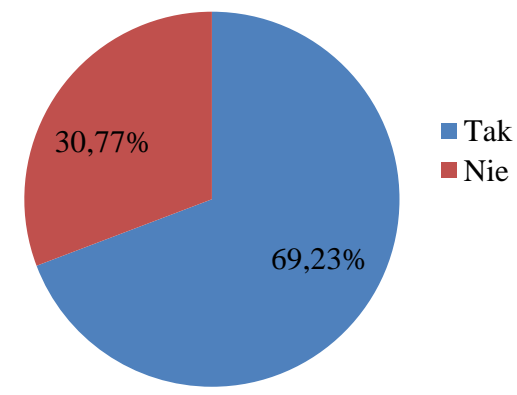

Ryc. 2. Odpowiedź na pytanie „Czy zna Pan/Pani przyczyny powstawania otyłości prostej u dzieci?" (\% osób) (A). Odpowiedź na pytanie „Czy zna Pan/Pani skutki otyłości prostej u dzieci?" (\% osób) (B) 
Wśród 54 ankietowanych potwierdzających wiedzę na temat przyczyn aż 83,33\% potrafiło wymienić również jej skutki. Wśród czynników powodujących otyłość najwięcej odpowiedzi (47) dotyczyło nieprawidłowej diety (ryc. 3), natomiast najczęściej podawanym skutkiem były powikłania sercowo-naczyniowe (41 osoby) (ryc. 4). Wykazano, że istnieje statystyczna zależność między znajomością przyczyn otyłości prostej u dzieci a znajomością jej skutków ( $\mathrm{p}=0,0012)$. Osoby, które znały czynniki powodujące otyłość, w większości potrafiły wskazać również jej skutki.

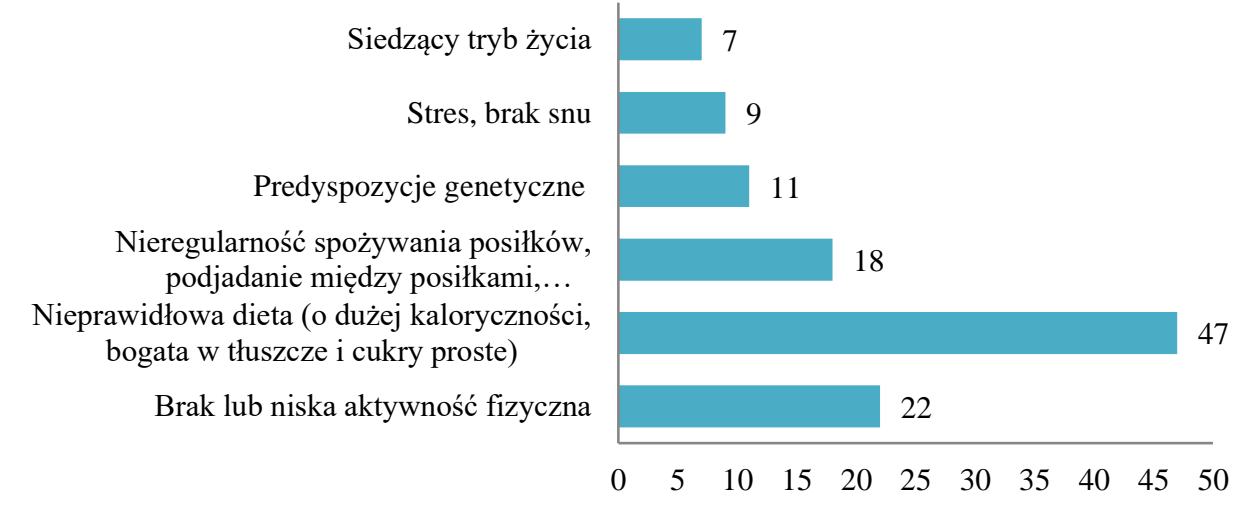

Ryc. 3. Przyczyny powstawania otyłości prostej u dzieci wymienione przez ankietowanych (ilość osób)

Zaburzenia hormonalne (np. przedwczesne dojrzewanie, zaburzenia miesiączkowania)

Psychospoleczne

Powikłania sercowo-naczyniowe (np. nadciśnienie tętnicze)

Choroby układu kostno-stawowego

Doleglwości ze strony układu oddechowego

(m.in. bezdech senny, astma)

Insylinooporność

Cukrzyca typu 2

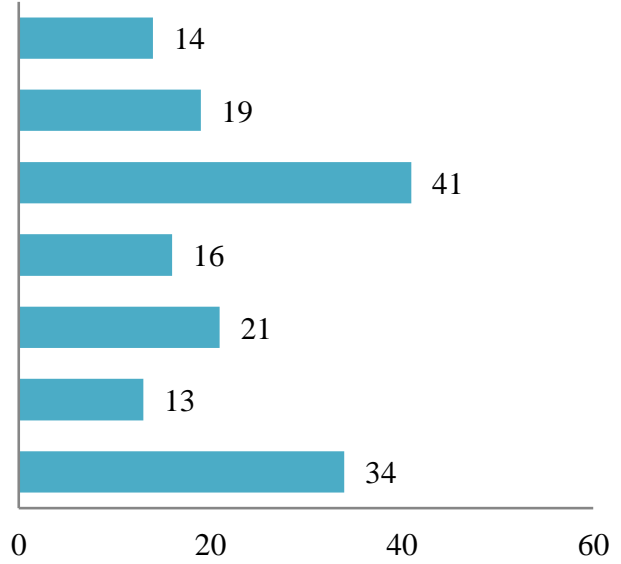

Ryc. 4. Skutki otyłości prostej u dzieci wymienione przez ankietowanych (ilość osób) 
Przeprowadzona ankieta wykazała, że prawie $90 \%$ badanych wiedziało, której grupy produktów powinno być najwięcej w diecie. Jedynie $6,73 \%$ osób stwierdziło, że podstawę diety powinny stanowić produkty zbożowe, a 4,81\% wskazało na mięso i jaja (ryc. 5).

$\mathrm{Z}$ analizowanych odpowiedzi wynika, że najwięcej dzieci $(63,46 \%)$ spożywa 4-5 posiłków dziennie. Niewiele ponad 1/5 ankietowanych wskazała na 3-4 posiłki, a blisko $14 \%$ na więcej niż 5 posiłków. Niecały $1 \%$ badanych stwierdził, że ich dziecko spożywa 1-2 posiłki w ciągu dnia (ryc. 6.A). Wykazano, że ponad połowa badanych rodziców podaje posiłki dzieciom o stałych porach dnia, natomiast niecałe $10 \%$ uważało, że dzieci nie jedzą regularnie (ryc. 6.B).

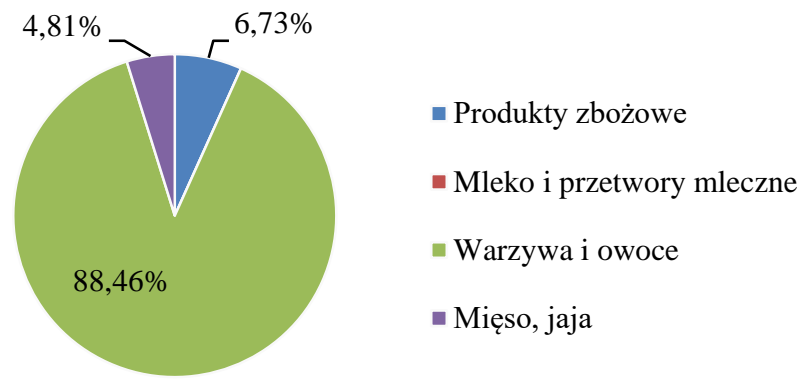

Ryc. 5. Odpowiedź na pytanie „Której grupy produktów Pana/Pani zdaniem powinno być najwięcej w diecie?" (\% osób)

A

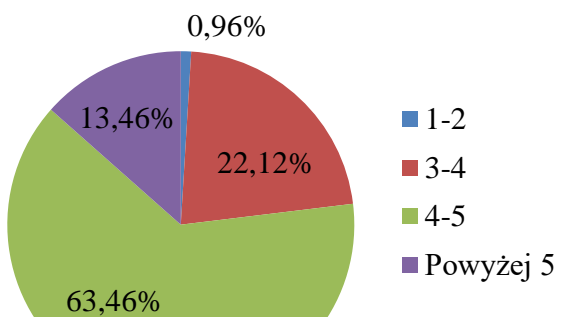

B

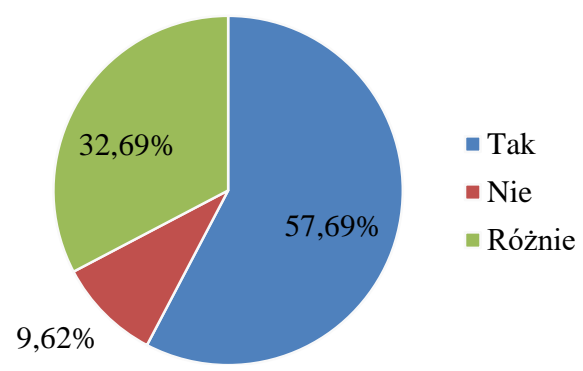

Ryc. 6. Odpowiedź na pytanie „Ile posiłków Pana/Pani dziecko spożywa w ciągu dnia?" (\% osób) (A). Odpowiedź na pytanie „Czy dziecko spożywa posiłki o stałych porach?" (\%osób) (B) 
Większość ankietowanych rodziców zazwyczaj przygotowywała posiłki zgodnie z zasadami prawidłowego żywienia, natomiast niespełna 15\% zadeklarowało, że zawsze kieruje się tymi zasadami (ryc. 7).

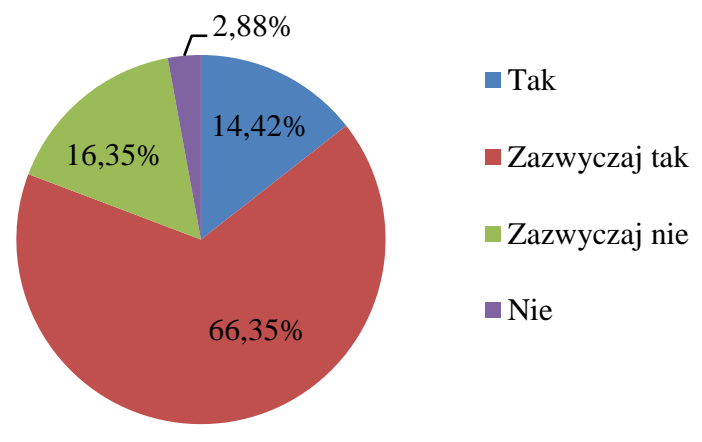

Ryc. 7. Odpowiedź na pytania „Czy posiłki przygotowywane w domu są sporządzane zgodnie z zasadami prawidłowego żywienia?" (\% osób)

A

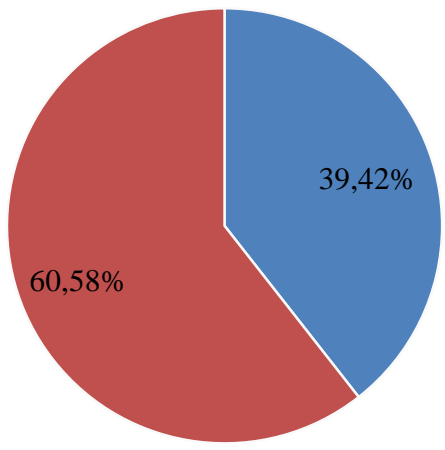

- Biernie (telewizja, komputer, nauka, czytanie książek)

- Aktywnie (jazda na rowerze, basen, zabawa na świeżym powietrzu, zajecia sportowe)

B

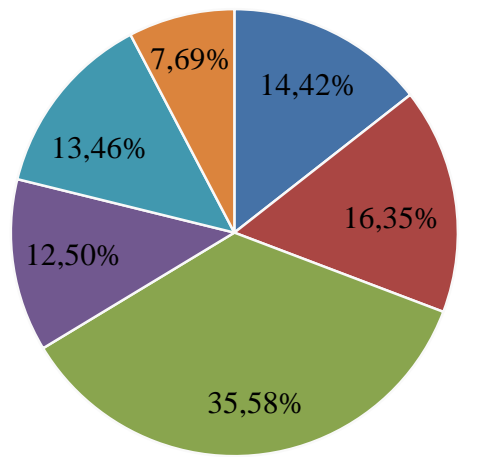

- Dziecko nie uprawia żadnego sportu

- Pływanie

- Jazda na rowerze, hulajnodze, rolkach

- Taniec

- Gry zespołowe (np. siatkówka, piłka ręczna)

- Inne

Ryc. 8. Odpowiedź na pytanie „Jak Pana/Pani dziecko spędza czas wolny?'” (\% osób) (A).

Odpowiedź na pytanie ,Jaką formę aktywności preferuje Pana/Pani dziecko poza zajęciami wychowania fizycznego w szkole?"' (\% osób) (B) 
Wykazano, że istnieje statystycznie istotna zależność między stosowaniem zasad prawidłowego żywienia podczas przygotowywania posiłków a ilością posiłków spożywanych przez dziecko $(\mathrm{p}=0,00000)$. Dzieci, które spożywały prawidłowo skomponowane posiłki, zazwyczaj otrzymywały je w odpowiednio rozłożonych racjach w ciągu dnia (4-5 posiłków).

Analiza ankietowanych wykazała, że większość dzieci spędza czas wolny aktywnie (60,58\%), natomiast formę bierną reprezentowało około $40 \%$ dzieci (ryc. 8 .A). W dalszej analizie wykazano, że $14,42 \%$ dzieci nie uprawiało żadnego dodatkowego sportu poza zajęciami wychowania fizycznego. Jako dodatkową formę aktywności dzieci zadeklarowano najczęściej jazdę na rowerze, hulajnodze czy rolkach (35,58\%) (ryc. 8.B).

\section{Podsumowanie}

W ankiecie wykazano, że znaczna większość rodziców zna zasady prawidłowego żywienia i stylu życia, w tym, dotyczące zalecanej ilości posiłków w ciągu dnia i stosowania odpowiednich technik podczas przygotowywania posiłków. Natomiast mniej niż połowa ankietowanych była świadoma zarówno przyczyny powstawania otyłości prostej u dzieci, jak i jej skutków zdrowotnych.

\section{Bibliografia}

Aggarwal B., Jain V., 2017. Obesity in Children: Definition, etiology and approach. Ind. J. Pediatrics 85, 463-471. https://doi.org/10.1007/s12098-017-2531-x

Ciborowska H., Rudnicka A., 2014. Dietetyka. Żywienie zdrowego i chorego człowieka. Warszawa, Wydawnictwo Lekarskie PZWL.

Daniels S.R., 2009. Complications of obesity in children and adolscents. Int. J. Obesity, 33, 60-65. https://doi.org/10.1038/ijo.2009.20

Gawlik A., Zachurzok-Buczyńska A., Małecka-Tendera E., 2009. Powikłania otyłości u dzieci i młodzieży. Endokrynol. Otyłość Zaburz. Przemiany Materii, 5, 19-27.

GIS (Główny Inspektorat Sanitarny), 2018. Otyłość dzieci i młodzież poważnym problemem globalnym. Warszawa. https://www.gov.pl/web/gis/otylosc-dzieci-i-mlodziezy-powaznym-problemem-globalnym [dostęp 22.02.2020]

Gogga P., Karbowska J., Meissner W., Kochan Z., 2011. Rola leptyny w regulacji metabolizmu lipidów i węglowodanów. Postęp. Hig. Med. Dośw., 65, 255-262. https://doi.org/10.5604/17322693.940259

Güngör N.K., 2014. Overweight and obesity in children and adolescents. J. Clin. Res. Pediatric Endocrinol. 6, 129-143. https://doi.org/10.4274/Jcrpe.1471

Harton A. 2013. Zachowania żywieniowe dzieci w Polsce. W: Zdrowie dzieci i młodzieży w wymiarze socjomedycznym, Szymborski R., Zatoński W. (red.). Wszechnica Polska Szkoła Wyższa w Warszawie, Warszawa, 115-143.

Instytut Żywności i Żywienia, 2019. Zasady prawidłowego żywienia. Warszawa. http://www.izz.waw.pl/zasady-prawidowego-ywienia [dostęp 10.02.2020]

IARC (International Agency for Research on Cancer), 2015. Half a milion new cancers in 2012 due to overweight and obesity. http://www.iarc.fr/en/media-centre/pr/2014/pdfs/pr229_E.pdf

Jarosz M. (red.). 2020. Normy żywienia dla populacji Polski. Instytut Żywności i Żywienia, Warszawa. 
Kołłajtis-Dołowy A., Jeruszka-Bielak A., Wawrzyniak A., 2019. Diety alternatywne, ich stosowanie w wybranych grupach osób oraz źródła informacji. Kosmos Probl. Nauk Biol., 68, 185200. https://doi.org/10.36921/kos.2019_2535

Lobstein T., Baur L., Uauy R., 2004. Obesity in children and young people: a crisis in public health. Obesity Rev., 5, 4-85. https://doi.org/10.1111/j.1467-789X.2004.00133.x

Maślanek A., Pieszko M., Małgorzewicz S., 2013. Przyczyny otyłości prostej u dzieci i młodzieży. Forum Zaburz. Metab., 4, 29-36.

Pilch W., Bałajewicz G., 2009. Ocena bilansu energetycznego u kuracjuszy podczas 21-dniowego turnusu sanatoryjnego. Rocz. PZH 1, 69-73.

Przybylska D., Kurowska M., Przybylski P., 2012. Otyłość i nadwaga w populacji rozwojowej. Hygeia Public Health, 47(1), 28-35.

Raj M., Krishna-Kumar R., 2010. Obesity in children \& adolscents. Ind. J. Med. Res., 132, 598-607.

Sikorska-Wiśniewska G., 2007. Nadwaga i otyłość u dzieci i młodzieży. Żywność Nauka Technol. Jakość, 6(55), 71-80.

Wolin K.Y., Carson K., Colditz G.A., 2010. Obesity and cancer. Oncologist, 12, 556-565. https://doi.org/10.1634/theoncologist.2009-0285 